Erik Saddi Arnesen

\title{
EDUCAÇÃO E CIDADANIA NA CONSTITUIÇÃO FEDERAL DE 1988
}

Dissertação de Mestrado apresentada ao Programa de Pós-graduação Strictu Sensu da Faculdade de Direito da Universidade de São Paulo

Orientadora Professora Associada Nina Beatriz Stocco Ranieri

Faculdade de Direito da Universidade de São Paulo

São Paulo, 2010 
BANCA EXAMINADORA 


\section{RESUMO}

Educação e cidadania são termos cujo conteúdo semântico é extremamente amplo. É importante, assim, definir uma abordagem específica para relacioná-los. Nesta Dissertação isso foi feito a partir do direito constitucional positivo vigente. $\mathrm{O}$ exercício do direito à educação, assim como dos demais direitos fundamentais, é uma exigência de cidadania, que, por sua vez, materializa-se no ordenamento posto e na prática jurídica dele decorrente. Impõe-se, portanto, a necessidade de compreensão com clareza da estrutura que o direito à educação assume no direito brasileiro. Para tanto, são verificadas suas diferentes dimensões, seus titulares, sua oponibilidade e seu objeto, entre outros aspectos.

\section{Agradecimentos}

Agradeço à minha mãe, Desirée, a quem dedico este trabalho, o amor, o carinhoso refúgio e a obstinação incansável em me fazer uma pessoa melhor. Agradeço ao meu pai, Finn, me ter dado, sem nunca questionar ou recriminar, a tranqüilidade para traçar meus próprios caminhos, certos e errados. Agradeço ao meu avô, Joaquim, o gosto pelas coisas jurídicas e o incentivo para aprendê-las, desde cedo. Agradeço à minha família os exemplos e o sempre presente apoio incondicional.

Agradeço a valiosa orientação da Professora Nina Beatriz Stocco Ranieri, cujas lições e idéias, desde minha graduação nesta Faculdade de Direito da Universidade de São Paulo, foram determinantes em meu desenvolvimento acadêmico.

Agradeço aos meus grandes e ácidos amigos, irmãos por escolha, a amizade verdadeira, sem a qual tudo teria sido muito mais difícil. Agradeço, especialmente, a Diogo Naves Mendonça, a inestimável paciência com a revisão do texto.

Agradeço a Deus e a Nossa Senhora Aparecida, num país e num mundo de tantas desigualdades, ter sido abençoado com tantas pessoas e razões para agradecer. 


\section{$\underline{\text { ÍNDICE }}$}

INTRODUÇÃ

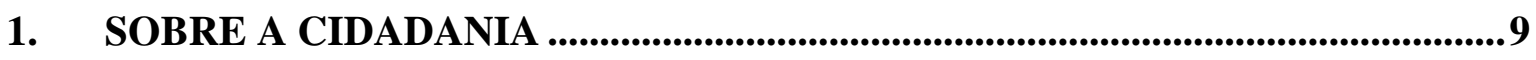

1.1. A NOÇÃO RESTRITA DE CIDADANIA: A EXPERIÊNCIA DE ATENAS. ...............................12

1.2. A AMPLIAÇÃO DA NOÇÃO DE CIDADANIA NA FORMAÇÃO DOS ESTADOS NACIONAIS: UM

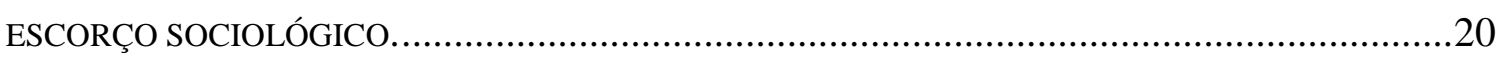

1.3. À PROCURA DE UM SIGNIFICADO JURÍDICO PARA A CIDADANIA ESTATAL. ......................36

1.4. O CONTEÚdo DO INCISO II DO ARTIGo 1º DA ConstituiçÃo Federal DE 1988: CIDADANIA COMO EXIGÊNCIA DE EFETIVAÇÃO DE DIREITOS FUNDAMENTAIS......................45

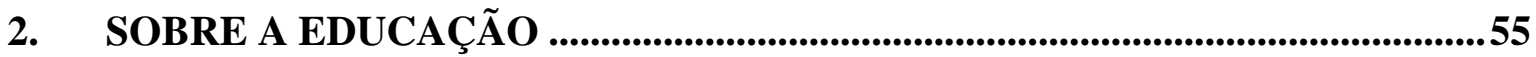

2.1. SIGNIFICADO DA EXPRESSÃO EDUCAÇÃO COMO LINGUAGEM JURÍDICA.........................55

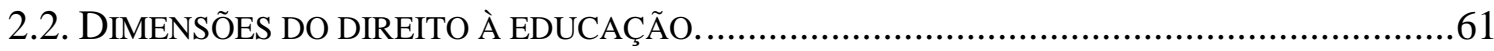

2.2.1. O direito à educação em sua dimensão de liberdade individual. ......................65

2.2.2. O direito à educação como direito social. ......................................................68

2.2.3. A dimensão coletiva do direito à educação: sua relação com o bem comum...72

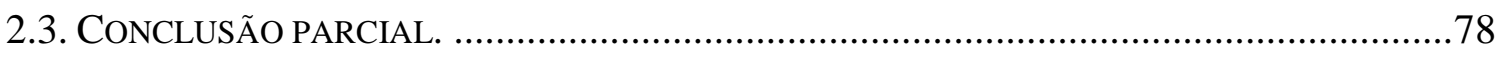

3. SOBRE O DIREITO POSITIVO À EDUCAÇÃO ...........................................8

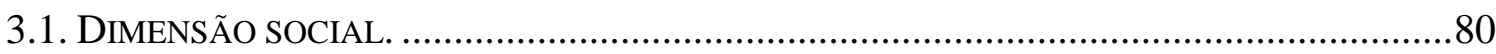

3.1.1. Parâmetros de vinculação e efetivação.............................................................8 80

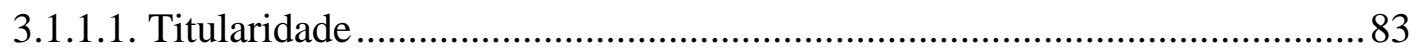

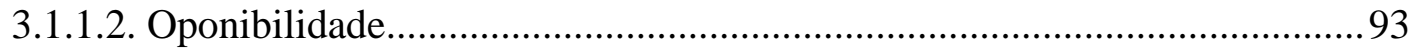

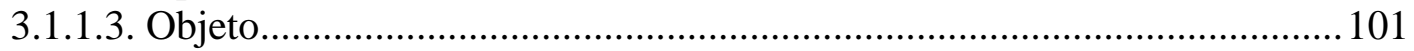

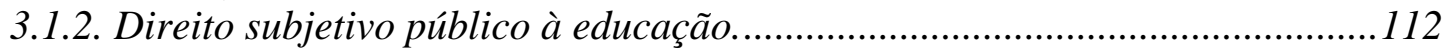

3.1.2.1. Do ensino fundamental à educação básica. ............................................. 115

3.1.2.2. A extensão do direito subjetivo à educação anterior à Emenda

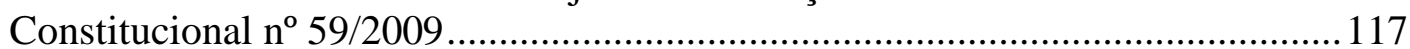

3.1.3. Imposições legiferantes de organização: a estrutura do direito social à

educação.

3.2. Dimensões DE LIBERDADE E COLETIVA DO DIREITO À EDUCAÇÃO: IMPLICAÇÕES RECÍPROCAS. 


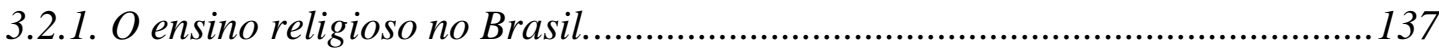

3.2.2. O ensino obrigatório (e conteúdos mínimos). ................................................ 140

3.2.3. A intervenção estatal na atividade educacional privada: a questão das mensalidades em atraso. ....................................................................................145

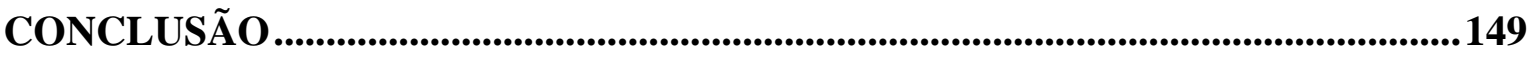

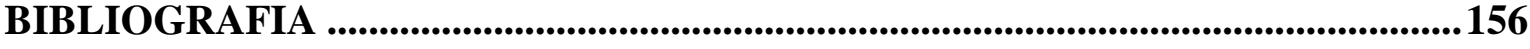




\section{INTRODUÇÃO}

Diferentes abordagens podem relacionar os temas da cidadania e da educação, vocábulos que contam com um vasto rol de significados possíveis. Assim, o estudo dessa relação poderia ser desenvolvido, por exemplo, em função da formação do indivíduo para sua participação na vida em sociedade, ou em função especificamente de sua formação para o exercício de seus direitos políticos de participação, ou, ainda, em função da preparação do indivíduo para o cumprimento dos deveres que tem em relação à coletividade. Também poderia ser abordado sob o prisma da assunção da educação como elemento essencial à perpetuação da figura do Estado, ou da posição especial do direito à educação no rol de direitos de cidadania. Esses são alguns exemplos.

Outra forma possível de relacionar os dois temas consiste em adotar cidadania como premissa atribuível ao indivíduo da qual decorrem determinados efeitos. Estes, para simplificar, podem ser designados por exigências de cidadania.

Para esse raciocínio, a expressão cidadania deve reportar-se a um significado amplo, que pode ser sintetizado da seguinte forma: o vínculo de pertencimento do indivíduo à sociedade estatal (à cidade). Então, acrescentando-se os efeitos ao conceito, tem-se que cidadania expressa um vínculo que impõe certas exigências. Essa abordagem conduzirá, conseqüentemente, à necessidade de esclarecimento sobre em que consistem esse vínculo e essas exigências (Capítulo 1 desta Dissertação).

O tema da educação surge em seguida: quais são as exigências de cidadania relativamente à educação? O que se tem com a resposta a essa pergunta, em verdade, é a abordagem da educação à luz da cidadania.

A investigação, nesses termos, bem poderia ser sociológica ou filosófica. Mas se feita sob o prisma jurídico, exige uma compreensão cuidadosa do ordenamento positivo e da estrutura que este propõe à educação. Falando-se já em direito à educação, esta estrutura representará como se dá, juridicamente, a exigência de cidadania relativamente ao tema.

Evidentemente, as imposições da cidadania não se limitam ao direito à educação. O mesmo tipo de análise seria possível em relação ao direito à saúde, à previdência, à 
propriedade, à liberdade de manifestação, ao desenvolvimento, ao meio ambiente saudável, e a todos os demais direitos tidos como fundamentais.

Adianta-se, já de início, que são exigências de concretização. A primeira delas é a própria declaração do direito à educação na ordem jurídica interna de uma sociedade. No Brasil isso é feito por sua positivação no texto constitucional.

Depois devem suceder tantas outras expressões dessas exigências conforme forem as medidas necessárias para que o direito à educação materialize-se. Trata-se da organização da educação em níveis, da delimitação de conteúdos juridicamente exigíveis, da identificação de sujeitos passivos e sujeitos ativos, da vinculação de recursos para fazer frente às prestações que o direito à educação encerra, da instituição de sistemas de regulação e de realização do ensino. Todas são igualmente exigências de cidadania. Na ordem jurídica brasileira elas se iniciam no Capítulo III do Título VIII da Constituição Federal de 1988.

A configuração dessas exigências responde à composição do próprio direito fundamental a que se referirem. À medida que prevalecer o caráter coletivo, social ou de liberdade, ou combinarem-se os três, a solução decorrente da cidadania obedecerá a uma forma específica (Capítulo 2 desta Dissertação). Mas esta deve ter sempre o objetivo de otimizar o exercício do direito. Obviamente, como se refere à incidência de uma ordem jurídica nacional (já que o vínculo é estabelecido entre o indivíduo e o Estado), essa organização do exercício do direito imposta pela cidadania observa as características da sociedade a que se refere (Capítulo 3 desta Dissertação). Entretanto, essa observância não deve ter a consequiência de negar o exercício do direito (como seria o caso de negar-se a educação de meninas em função da crença religiosa partilhada).

Ademais, além do exercício de direitos, as exigências de cidadania também ensejam deveres, fundados no mesmo vínculo de pertencimento. Isso significa que o indivíduo que participa do bem comum deve retribuir à sociedade através de formas que também são definidas juridicamente. Inserem-se nesse contexto as obrigações tributárias, o serviço militar e o serviço eleitoral. No Brasil, é o caso, também, do ensino obrigatório dos quatro aos dezessete anos. Essa obrigatoriedade reproduz as expectativas da sociedade 
brasileira em relação a seus membros, para quem, em contraposição, ela se organiza para viabilizar o exercício do direito à educação ${ }^{1}$.

Nesta Dissertação objetiva-se analisar as exigências da cidadania - conforme definidas na ordem jurídica constitucional brasileira - acerca do direito à educação. Com esse fim, o Capítulo 1 dedica-se a esclarecer de forma mais aprofundada o significado de cidadania adotado. O Capítulo 2, por sua vez, dedica-se a explorar, de forma abstrata, a educação enquanto elemento do enunciado direito à educação, de forma que seja possível perceber como nele se combinam as dimensões coletiva, social e de liberdade. Por fim, o Capítulo 3 destina-se à investigação da estrutura proposta pelo ordenamento positivo brasileiro em atenção às exigências de cidadania acerca do direito à educação.

\footnotetext{
1 “O Estado, como sociedade política, tem expectativas em relação aos titulares que, nesse sentido, são também sujeitos passivos do direito à educação. Tais expectativas traduzem-se nas exigências da cidadania, que demandam participação política e contribuição individual e coletiva para a construção dos objetivos nacionais" in RANIERI, Nina Beatriz Stocco, O Estado Democrático de Direito e o Sentido da Exigência de Preparo da Pessoa para o Exercício da Cidadania, pela Via da Educação, Tese (Livre-Docência) Faculdade de Direito da Universidade de São Paulo, São Paulo, 2009, p.281.
} 


\title{
1. SOBRE A CIDADANIA
}

\author{
O âmbito de uma teoria da cidadania é \\ potencialmente ilimitado - quase todo problema em \\ filosofia política envolve relações entre cidadãos ou \\ entre cidadãos e o Estado ${ }^{2}$ (tradução livre)
}

Como se sabe, a Constituição é documento político, destinado a toda a coletividade e não apenas aos habituados à técnica jurídica. Desta feita, o intérprete deve estar apto a reconhecer em seu texto, muitas vezes, o coloquialismo nos termos utilizados ${ }^{3}$. Ou seja, é preciso ter presente que uma mesma expressão pode ser empregada com diversos significados ao longo do texto constitucional. Sem dúvida, esta é uma preocupação que deve ser considerada no tocante ao tema da cidadania.

No artigo $1^{\circ}$, inciso II, a Constituição Federal de 1988 afirma que a República Federativa do Brasil, constituída em Estado democrático de direito, tem a cidadania como um de seus fundamentos.

A expressão também é empregada no inciso LXXI do artigo $5^{\circ}$, ao afirmar que “conceder-se-á mandado de injunção sempre que a falta de norma regulamentadora torne inviável o exercício dos direitos e liberdades constitucionais e das prerrogativas inerentes à nacionalidade, à soberania e à cidadania".

O inciso LXXIII do mesmo artigo menciona cidadão como parte legítima para propor ação popular, e o inciso LXXVII prevê gratuidade dos atos para o exercício da cidadania, na forma da lei. ${ }^{4}$

\footnotetext{
${ }^{2}$ Kymlicka, Will et Norman, Wayne, Return of the Citizen: A Survey of Recent Work on Citizenship Theory, in Ethics, v. 104, n. 2, 1994, p. 353.

${ }^{3}$ Sobre o princípio do coloquialismo como técnica de hermenêutica constitucional ver DAVID ARAÚJO, Luiz Alberto e NunES JúnIOR, Vidal Serrano, Curso de Direito Constitucional, São Paulo, Saraiva, 1999, p. 51.

4 A regulamentação do inciso LXXVII do artigo $5^{\circ}$ da Constituição Federal de 1988 faz com a Lei Federal ${ }^{\circ}$ 9.265/96 da seguinte forma:

Art. $1^{\circ}$ São gratuitos os atos necessários ao exercício da cidadania, assim considerados: I - os que capacitam o cidadão ao exercício da soberania popular, a que se reporta o art. 14 da Constituição; II - aqueles referentes
} 
Na Constituição Federal de 1988, ainda, estabelece-se no inciso XIII do artigo 22 a competência privativa da União para legislar sobre "nacionalidade, cidadania e naturalização". Já o artigo 58 assegura às comissões parlamentares a prerrogativa de "solicitar depoimento de qualquer autoridade ou cidadão", e o artigo 61 garante aos cidadãos a iniciativa na propositura de leis complementares e ordinárias.

Os artigos 62 e 68, por sua vez, vedam a edição de medidas provisórias e leis delegadas, respectivamente, sobre nacionalidade, cidadania, direitos políticos, partidos políticos (em relação à medida provisória) e direito eleitoral.

A expressão cidadão também é utilizada para indicar os legitimados a oferecer denúncias ao Tribunal de Contas da União (artigo74), bem como é elemento de composição do Conselho da República (artigo 89), da Justiça de Paz (artigo 98), do Supremo Tribunal Federal (artigo 101), do Conselho Nacional de Justiça (artigo 103-A) e do Conselho Nacional do Ministério Público (artigo 130-A). A expressão ainda é usada como critério de escolha do Advogado-Geral da União (artigo 131, § $1^{\circ}$ ).

Por fim, há a norma do artigo 205 da Carta da República, segundo a qual $a$ educação, direito de todos e dever do Estado e da família, será promovida e incentivada com a colaboração da sociedade, visando ao pleno desenvolvimento da pessoa, seu preparo para o exercício da cidadania e sua qualificação para o trabalho.

Evidentemente, o significado da expressão cidadania não é constante em todas essas passagens. Ora é singelo, como na ocasião em que indica a necessidade de apresentação do título de eleitor para a prova da cidadania enquanto condição da ação popular $^{5}$, ora muito mais complexo, como quando ela é arrolada dentre os fundamentos do Estado brasileiro.

Isto posto, é necessário uma definição metodológica: neste estudo, trabalha-se com a cidadania constante do inciso II do artigo $1^{\mathrm{o}}$ da Constituição Federal, ou seja, como fundamento da República brasileira. Nessa perspectiva, o conceito deve ser amplo, excedendo a tradicional identificação entre cidadania e titularidade de direitos políticos.

ao alistamento militar; III - os pedidos de informações ao poder público, em todos os seus âmbitos, objetivando a instrução de defesa ou a denúncia de irregularidades administrativas na órbita pública; IV - as ações de impugnação de mandato eletivo por abuso do poder econômico, corrupção ou fraude; V - quaisquer requerimentos ou petições que visem as garantias individuais e a defesa do interesse público.

${ }^{5}$ Cf. Lei $n^{\circ} 4.717 / 65$, art. $1^{\circ}, \S 3^{\circ}$ : "A prova da cidadania, para ingresso em juízo, será feita com o título eleitoral, ou com documento que a ele corresponda". 
Assim, adota-se o seguinte significado: cidadania é condição individual que indica a vinculação jurídica a determinada sociedade politicamente organizada (pertencimento), cujo efeito é permitir ao indivíduo a fruição de direitos civis, políticos e sociais. Trata-se de um pressuposto de exercício de direitos fundamentais que, muito além de sua mera titularidade no plano do direito positivo, envolve os mecanismos jurídicos de sua efetivação. Estes instrumentos correspondem à organização na Constituição e/ou na Lei da implementação desses direitos fundamentais (tal como ocorre com o direito à educação, minuciosamente regulado na Constituição Federal, desde os objetivos do sistema de ensino até as reservas orçamentárias mínimas). Correspondem, ainda, à previsão de garantias eficazes para a tutela de tais direitos (ações individuais e coletivas), à presença de instituições oficiais com atribuição para exercer essa tutela na impossibilidade de o indivíduo fazê-lo por sua própria força (como o Ministério Público e a Defensoria Pública), à implementação de políticas públicas voltadas à realização de tais direitos, entre outros aspectos. Ou seja, tudo aquilo que permite ao indivíduo efetivamente exercer os direitos fundamentais de que é titular insere-se no conceito de cidadania.

Esse conteúdo parece satisfazer a complexidade de se ter a cidadania como fundamento da República: um mandamento de que os direitos fundamentais sejam exercidos por seus titulares. Ademais, ressalte-se que os próprios direitos fundamentais alçam à qualidade de fundamento do Estado, já que o inciso III do artigo $1^{\circ}$ menciona a dignidade da pessoa humana.

Todavia, o caminho para a eleição de um conceito de cidadania não é simples. Trata-se de matéria que pode ser estudada sob os mais diversos pontos de vista (sociológico, histórico, político, jurídico etc.), o que confere ao tema da cidadania uma vasta pluralidade de possíveis significações. De modo que o pesquisador deve manter o cuidado de escolher uma linha de análise do tema da cidadania com que possa trabalhar. Numa pesquisa jurídica como esta, que avalia como se relacionam cidadania e educação dentro de um texto normativo que é a Constituição, o conceito e a linha de análise escolhidos devem ser jurídicos.

Para fundamentar a decisão conceitual adotada neste trabalho (cidadania enquanto vínculo de pertencimento do indivíduo à sociedade estatal, do qual decorre uma exigência ao exercício de direitos fundamentais) opta-se pela seguinte estrutura: (i) verificação do significado (restritivo) de cidadania na antiguidade, a partir de breve explanação da expansão da democracia ateniense; (ii) verificação do refortalecimento da cidadania com o 
final do sistema feudal e o processo de formação do Estado nacional, principalmente a partir do pensamento de MARSHALL ${ }^{6}$, indubitavelmente autor de uma das doutrinas mais suscitadas sobre o tema; (iii) perquirição por possíveis significados jurídicos de cidadania; e, finalmente, (iv) definição do conceito eleito neste trabalho.

O significado excessivamente restritivo e intimamente ligado à titularidade e ao exercício de direitos políticos que se verifica na experiência antiga é ampliado em extensão e conteúdo no processo de formação do Estado nacional. Todavia, diferenças nos diversos processos de formação dos Estados nacionais e os resultados que elas possam implicar ao pertencimento do indivíduo a determinada sociedade política são estudos que podem extrapolar a ótica jurídica, especialmente quanto à titularidade e ao exercício de direitos fundamentais. É o que se exporá adiante.

Com tal análise objetiva-se, além de fundamentar a escolha feita, evidenciar a pluralidade conceitual relativa à cidadania, bem como o cuidado que deve ter o pesquisador em não fundamentar seu trabalho sobre um substrato que eventualmente extravase o campo de sua pesquisa.

\subsection{A noção restrita de cidadania: a experiência de Atenas.}

O estudo da conceituação de cidadania poderia iniciar-se em diferentes momentos históricos - na antiguidade, na vassalagem feudal, nas Revoluções Liberais dos séculos XVII e XVIII -, sendo que nenhum deles parece garantir ao pesquisador tranqüilidade suficiente para enxergar completude em sua exposição. Como afirmaram KYMLICKA e NORMAN, o "âmbito de uma teoria da cidadania é potencialmente ilimitado - quase todo problema em filosofia política envolve relações entre cidadãos ou entre cidadãos e o Estado" 7 (tradução livre).

\footnotetext{
${ }^{6}$ MARShall, Thomas Humphrey, Ciudadania y Classe Social, in Reis, v. 79, 1997. Ou MARSHALl, Thomas Humphrey, Cidadania, Classe Social e Status, Rio de Janeiro, Zahar, 1967.

${ }^{7}$ Kymlicka, Will et Norman, Wayne, Return of the Citizen: A Survey of Recent Work on Citizenship Theory, in Ethics, v. 104, n. 2, 1994, p. 353.
} 
Considerando os objetivos propostos para este estudo, a investigação pode se iniciar com a inspeção das origens antigas da cidadania ${ }^{8}$, especificamente, da experiência grega em Atenas entre os séculos IX a V a.C..

Nesse período antigo, constatam-se, grosso modo, manifestações conceituais acerca de cidadão e cidadania ${ }^{9}$ desvinculadas de noções de liberdade e autonomia individual. Pelo contrário, a filosofia grega da época indicava que a relação entre cidadão e cidade-Estado compunha-se a partir do fundamento de que todos os indivíduos deviam comportar-se em função da polis, único espaço a permitir o pleno desenvolvimento humano.

DAL RI JÚNIOR explica que o conceito de cidadão, na Atenas da Antiguidade, representava a figura do homem adulto livre, ligado à polis por vínculos de sangue (descendente de outro cidadão) e "intimamente comprometido com a defesa dos interesses da cidade-Estado" ${ }^{\prime 10}$. Portanto, tratava-se de condição atribuída a poucos, da qual estavam excluídos escravos, mulheres e estrangeiros, parcela numericamente importante da população ateniense.

Essa configuração restritiva teria relação próxima com o quanto denotava o conceito à época: um conteúdo de liberdade não individual, como afirmado, mas de liberdade positiva da coletividade conformada como a idéia de autonomia coletiva, de autogoverno ou autodeterminação ${ }^{11}$. Mulheres, escravos e estrangeiros possuíam, em alguma medida, direitos individuais, mas não direitos de participação na esfera pública de decisão. Estes eram reservados aos cidadãos ${ }^{12}$.

\footnotetext{
${ }^{8}$ Acerca da cidadania na Grécia antiga ver MANVILLE, Philip Brook, The Origins of Citizenship in Ancient Athens, Princeton University Press, 1990.

9 DAL RI JÚNIOR afirma não existir na antiguidade grega o termo cidadania, sendo possível, no entanto, reconhecer uma noção de virtude cívica, cujo conteúdo e função aproximar-se-iam do que hoje é trabalhado como cidadania, in DAL RI JÚNIOR, Arno, Evolução Histórica e Fundamentos Políticos-Jurídicos da Cidadania, in DAL RI JúNIOR, Arno et OliveIRA, Odete Maria de (org.), Cidadania e Nacionalidade: efeitos e perspectivas nacionais - regionais - globais, Ijuí, Unisul, 2002, p.26.

${ }^{10}$ DAL Ri Júnior, Arno, Evolução Histórica... cit, p. 26.

${ }^{11}$ Cf. RIBEIRO, Gustavo Moulin, A Cidadania Jurídica e a Concretização da Justiça, in ToRRES, Ricardo Lobo (org.), Legitimação dos Direito Humanos, Rio de Janeiro, Renovar, 2007, p. 373.

${ }_{12}$ Mais que direito, a participação na vida pública era tida como obrigação do cidadão, que devia empenharse em tal atividade com, pelo menos, o mesmo vigor com que exercia seus negócios privados, conforme se observa na Oração Fúnebre de PÉRICLES: "Our public men have, besides politics, their private affairs to attend to, and our ordinary citizens, though occupied with the pursuits of industry, are still fair judges of public matters; for, unlike any other nation, regarding him who takes no part in these duties not as unambitious but as useless, we Athenians are able to judge at all events if we cannot originate, and, instead of looking on discussion as a stumbling-block in the way of action, we think it an indispensable preliminary to any wise action at all" in THUCYDIDES, History of the Peloponnesian War, L. II, C. I, 431 a.C. (disponível em meio eletrônico em http://classics.mit.edu/Thucydides/pelopwar.html).
} 
De certa forma, a edificação de um significado ateniense antigo para cidadania está ligada à instalação e à reverência daquela sociedade às instituições democráticas. VASCONCELOS $^{13}$ ensina que o cidadão, único beneficiário da democracia ateniense, firmouse como concepção a partir do reconhecimento de direitos políticos à parcela da população da polis identificada por essa alcunha (masculina, descendente etc.), direitos que "se ampliavam na medida em que se alargava o conteúdo democrático do regime, até alcançar, sob Péricles, sua máxima expressividade" ${ }^{\prime 14}$.

De fato, conforme leciona VASCONCELOS ${ }^{15}$, a figura do cidadão ateniense era condição de existência daquela democracia, porque era através dele que ela se realizava, e foi através dos direitos a ele atribuídos que se deu sua configuração, sendo que essa atribuição termina por se confundir com a própria gênese do conceito.

O que se nota, portanto, nesse momento inicial de significação, é que o exercício ativo da democracia e o conceito de cidadania possuem inafastável conexão. Vê-se a seleção de um segmento da sociedade (homens, descendentes, proprietários etc.) ao qual gradualmente são atribuídos direitos e obrigações diretamente ligados ao exercício do poder político em Atenas.

VASCONCELOS $^{16}$ apresenta esse desenvolvimento em direção à democracia, desenrolado sob diferentes governantes da Atenas antiga, que teria se iniciado com Íon (séculos IX a XVII a. C.) e alcançado seu auge sob o poder de Péricles (século V a. C.), passando por Teseu, Dracon, Sólon, Pisístrato, Clístenes, Temístocles e Efialtes.

Íon, personagem que transita entre a história e a mitologia, teria inaugurado o caminho à democracia ateniense dividindo, pela primeira vez com finalidade institucional, os atenienses em quatro tribos, cada uma governada por um basileu, assistido por um conselho de anciães e por uma assembléia popular.

Sob Teseu, Atenas assumiria efetivamente a forma de Estado unitário, com a promessa ao povo (em verdade, aos proprietários de terra considerados cidadãos) de organização de um autogoverno cidadão, não subordinado ao poder de um único soberano.

\footnotetext{
${ }^{13}$ Vasconcelos, Arnaldo, A Cidadania Ateniense na Grécia Clássica, in SAlEs, Lília Maia de Morais (org.), Estudos sobre a efetivação do direito na atualidade: a Cidadania em Debate, Fortaleza, Universidade de Fortaleza, 2005, p. 52.

${ }^{14}$ VAsCONCELOS, Arnaldo, A Cidadania... cit, p. 52.

${ }^{15}$ Vasconcelos, Arnaldo, A Cidadania... cit, pp. 7 a 9.

${ }^{16}$ VASCONCELOS, Arnaldo, A Cidadania... cit, pp. 13 a 34.
} 
Exceção feita à superintendência de guerra e à guarda das leis, todo cidadão seria igualmente dotado de direitos e responsabilidades em relação à gestão da coisa pública ${ }^{17}$.

Com Dracon (621-629 a.C.) o principal aperfeiçoamento veio através da publicação de seus códigos, com vistas a atribuir maior certeza acerca do direito, tendo, ainda, instituído instrumentos para que o indivíduo injustiçado pudesse reclamar a recomposição de seu direito junto ao poder público, no caso, junto ao Conselho formado por quatrocentos e um membros sorteados dentre aqueles que detinham poder político. Contudo, ARISTÓTELES registrou que politicamente o perfil foi conservador, numa situação em que “[e]mpréstimos eram feitos sob garantia na pessoa do emprestador, [...] a terra estava sob controle de poucos homens" e "a maioria era escravizada por poucos"18.

A conflituosa situação política procedente desses elementos conduziu à atribuição de $\operatorname{poder}^{19}$ a Sólon (sec. VI a.C.), cujas reformas foram determinantes para o êxito do Estado ateniense e para a efetivação da democracia. VASCONCELOS ${ }^{20}$ esclarece que tais reformas podem ser segregadas em duas etapas: na primeira, voltou esforços à tranquilização das contendas entre pobres e ricos, o que fez com a extinção imediata de todas as dívidas existentes, "tanto particulares como públicas, que os homens denominaram seisachtheia porque os livrou de seu peso" ${ }^{21}$, bem como com a eliminação da garantia corporal de obrigações; na segunda, Sólon buscou a constituição de uma ordem social mais igualitária, em que o poder político fosse, o quanto possível, partilhado entre os grandes proprietários e os cidadãos menos afortunados.

Para tanto, conforme assinalou ARISTÓTELES, Sólon “[d]ividiu o povo em quatro classes proprietárias de acordo com a riqueza" ${ }^{22}$ : pentacosiomedimni, hippeis, zeugitae e thetes. Às três primeiras classes, compostas de grandes e médios proprietários, foi reservado o preenchimento de todas as vagas das magistraturas (arcontes, tesoureiros etc.). Já "[o]s thetes tinham apenas o direito de sentar-se na Eclésia e no dicastério"23, ou seja, a

\footnotetext{
${ }^{17}$ Cf. VAsconcelos, Arnaldo, A Cidadania... cit, p. 14.

${ }^{18}$ ARISTÓTELES, A Constituição de Atenas (trad. Therezinho M. Deutsch), in Aristóteles, col. Os Pensadores, São Paulo, Nova Cultural, 1999, pp. 257 e 258.

${ }^{19}$ Cf. Aristóteles, A Constituição... cit, p. 258.

${ }^{20}$ VASCONCELOS, Arnaldo, A Cidadania ... cit, p. 17.

${ }^{21}$ ARISTÓTELES, A Constituição... cit, p. 258.

${ }^{22}$ ARISTÓTELES, A Constituição... cit, p. 259.

${ }^{23}$ ARISTÓTELES, A Constituição... cit, p. 259.
} 
eles era conferido o direito de participação na gestão pública mediante o voto nas Assembléias, assim como nos julgamentos ${ }^{24}$.

Assim, embora as reformas de Sólon tenham representado importante passo, ainda seria necessário, para a consagração da democracia, transpor o obstáculo representado pelo impedimento de acesso aos cargos públicos aos thetes, maioria da cidadania ateniense. $\mathrm{O}$ que se constata, na realidade, são duas categorias de cidadania ${ }^{25}$ : de primeira categoria, composta pelas primeiras três classes, cujo acesso aos cargos públicos era irrestrito; e, de segunda categoria, composta pelos thetes, cuja participação restringia-se ao exercício do voto.

Tendo em vista a finalidade deste estudo, mostra-se importante evidenciar que a identificação de duas categorias de cidadania dá-se em função de serem os cidadãos de uma e de outra categoria titulares de direitos e responsabilidades diferentes em relação ao modo e à medida que participam na gestão da polis. Este ponto será retomado adiante.

Pisístrato (aprox. 546 a 527/8 a.C.), que concentra o poder em Atenas após Sólon, sob a forma de uma tirania, cumpriu, todavia, a última etapa para a consagração da democracia $^{26}$, tendo governado "o Estado mais como cidadão particular do que como tirano"27. Manteve a constituição de Sólon, não alterando a estrutura organizacional de exercício do poder. Porém, interpretou-a segundo as necessidades da sociedade. Esse foi seu grande êxito, porque desse modo foi capaz de alterar substancialmente o regime político ateniense, sem insuflar contra si maiores oposições.

Sua principal ação foi a distribuição das terras, confiscadas de grandes proprietários aristocratas, entre o povo miúdo. Esse esforço resultou na conformação de uma numerosa classe média cidadã, economicamente independente, em Atenas, ampliando, assim, o universo de participação política ativa. Sob seu comando, adicionalmente, fortaleceu-se o poderio militar marítimo de Atenas, fato de grande relevância considerando-se que foi a hegemonia desta cidade no mar Egeu que, através da cobrança de tributos das demais

\footnotetext{
24 Acerca das quatro classes instituídas por Sólon, ARISTÓTELES esclareceu: “[p]ara ser um pentacosiomedimnus era preciso provar que se tinha uma propriedade que dava no mínimo um retorno anual, para a própria propriedade, de 500 medidas, entre secos e molhados. Os hippeis tinham que ter um retorno de no mínimo 300 e alguns afirmam que esta classe também era restrita aos que se mostravam capazes de sustentar um cavalo; [...] a qualificação mínima para os zeugitae era de 200 medidas, secos e molhados combinados, enquanto o restante da população formava os thetes, que não eram habilitados a ocupar cargos" in ARISTÓTELES, A Constituição... cit, p. 259 e 260.

${ }^{25}$ Cf. VASCONCElos, Arnaldo, A Cidadania... cit, p. 17.

${ }^{26}$ Cf. VAsconcelos, Arnaldo, A Cidadania... cit, p. 20.

${ }^{27}$ ARISTÓTELES, A Constituição... cit, p. 265.
} 
cidades-Estado, posteriormente garantiu aos cidadãos atenienses a possibilidade de desfrutarem de uma vida inteiramente dedicada aos assuntos políticos.

A Pisístrato sucedeu a tirania de seus filhos Hiparco e Hípias. Seu regime correspondeu ao que efetivamente se entende por tirania, não tendo demonstrado o apoio ao povo e a benevolência de seu pai.

Após a tirania, deu-se o governo de Clístenes, que "dividiu todos os cidadãos em dez classes, em vez das quatro anteriores, com a finalidade de misturá-los para que melhor participassem do controle do Estado" ${ }^{28}$. A vontade do estadista era, conforme ensinou KenYON $^{29}$, responsável pela editio princeps da Constituição de Atenas de Aristóteles, a de desfazer a antiga divisão tribal com propósitos políticos, quais sejam, os de eliminar todas as velhas tradições e associações aristocráticas que impediam às classes inferiores de efetivamente tomar parte na vida pública ${ }^{30}$.

Clístenes aproveitou-se da situação de que, com a tirania antecedente, as leis de Sólon haviam perdido sua eficácia ${ }^{31}$, para reformá-las com vistas à obtenção de maior apoio popular, garantindo maior participação. A organização do poder, assim efetivada, ficou, de modo geral, mais democrática do que aquela instituída por Sólon ${ }^{32}$.

As reformas institucionais de Temístocles e Efialtes ${ }^{33}$, que se seguiram a Clístenes, embora menos expressivas que as anteriores, concluíram o processo de atribuição de poder

\footnotetext{
${ }^{28}$ ARISTÓTELES, A Constituição... cit, p. 272.

${ }^{29}$ KENYON, Frederic George, Aristotle on the Constitution of Athens, London, 1892, p 68.

${ }^{30}$ KENYON relata a ação de Clístenes para ampliação do número de cidadãos e sua preocupação com o estabelecimento de igualdade entre antigos e novos cidadãos, que motivou a alteração na própria designação dos indivíduos no âmbito público: "Cleisthenes introduced a large number of new citizens by the enfranchisement of emancipated slaves and resident aliens, and he made their reception into the community easier by altering the official mode of designation. If described by their father's name alone, the new citizens who, so to speak, 'had no father,' would be easily distinguished from the older citizens, who were proud of their family pedigrees; but by adding the name of the deme as part of the necessary description a novelty was introduced into the designation of all alike, and the fact of a man having a deme would be sufficient proof of his being a citizen, which in the case of those, newly admitted to the franchise would not be obvious from the unfamiliar and sometimes foreign name of his father" in KENYON, Frederic George, Aristotle... cit, p. 69 e 70 .

${ }^{31}$ Cf. ARistóteles, A Constituição... cit, p. 272 e 273.

32 Afirma VASCONCELOS: "Com efeito, a constituição clisteniana firmou a democracia sobre bases igualitárias, sem levar em conta diferenças relativas a nascimento, fortuna ou classe social" in VASCONCELOS, Arnaldo, A Cidadania... cit, p. 24.

${ }^{33}$ VASCONCELOS aponta, acerca de Temístocles, a importância da consagração do domínio militar marítimo de Atenas, cujo papel no desenvolvimento da democracia compreende dois principais efeitos dessa dominação: fortalecimento dos marinheiros, "gente pobre e humilde" a quem, em face do sucesso militar, não podia ser negada mais efetiva participação na gestão pública; e, com a tributação das cidades-Estado dominadas, o fato de que "[o] suporte econômico da democracia ateniense deixava de ter apenas um pilar de apoio, a escravatura, que a sustentara durante cerca de cento e vinte anos. No século $\mathrm{V}$, foi o império marítimo que desempenhou de modo preponderante este papel, possibilitando atingisse então a democracia seus últimos limites". Sobre Efialtes, aponta duas principais reformas a contribuir com o enfraquecimento da
} 
aos cidadãos miúdos (pequenos proprietários e aqueles que viviam apenas de seu trabalho) e de enfraquecimento da aristocracia que ensejou a democracia plena, cujo apogeu ocorreu sob Péricles.

Conforme afirmou ARISTÓTELES, "[c]om Péricles o Estado tornou-se ainda mais democrático; ele privou o Areópago de alguns dos seus poderes e dirigiu o Estado principalmente para o poder naval, com o resultado de que o povo teve coragem de tomar todos os campos do governo em suas mãos" ${ }^{34}$. Através de sua gestão, concretizou-se o império ateniense no Mar Egeu, o que lhe permitiu promover mudanças de caráter eminentemente econômico, cujo objetivo era a melhoria da vida do cidadão ateniense com vistas a aproximá-lo ainda mais da vida pública da polis $^{35}$.

Nesse sentido a índole de sua principal medida em benefício da cidadania, tomada sob as facilidades político-econômicas garantidas pelo sucesso militar de Atenas, que provia espólios de guerra e tributos cobrados das cidades-Estado súditas e aliadas. Trata-se da criação do Estado Empregador ${ }^{36}$, que pagava salários aos ocupantes de cargos públicos, para que, desse modo, pudessem dedicar-se somente a essa atividade. Entusiasta da retórica e do movimento sofista, "[a]s principais reformas de Péricles [...] visavam à educação do cidadão para o exercício democrático. Por isso, foram, em essência, mudanças nos costumes políticos, na qual a oratória desempenhou importante função legitimadora” ${ }^{37}$.

A conclusão que se extrai de cidadania na Grécia antiga, portanto, é que constitui conceito voltado à atividade pública. Refere-se a uma condição, cujos atributos foram sendo incorporados à medida que se consolidava a democracia plena ateniense, em geral transmitida via laços sanguíneos ${ }^{38}$, que identificava um número restrito de indivíduos

aristocracia: " $1^{\mathrm{a}}$ - o Conselho dos Quinhentos [composição representativa de toda a cidadania] passa a desempenhar a função de suprema corte de justiça, ampliando ainda mais seus altos poderes. [...] $2^{\mathrm{a}}-\mathrm{o}$ Conselho do Areópago [composição essencialmente aristocrática] sofre novo processo de esvaziamento, sendo privado de sua função de vigilância constitucional" in VASCONCELOS, Arnaldo, A Cidadania... cit, p. 25 a 27.

${ }^{34}$ ARISTÓTELES, A Constituição... cit, p. 277.

${ }^{35}$ Cf. VAsCONCElos, Arnaldo, A Cidadania... cit, p. 29.

${ }^{36}$ Cf. VAsconcelos, Arnaldo, A Cidadania... cit, p. 31. Ver também ARISTóteles, A Constituição... cit, p. 277 e 278.

${ }^{37}$ VASCONCELOS, Arnaldo, A Cidadania... cit, p. 32.

38 Cf. explica DAL RI JUNIOR, em Atenas, a condição de cidadão era transmitida pelo critério do jus sanguinis, ainda que o indivíduo não fosse "fruto de uma relação legítima. [...] Em nenhuma hipótese era determinada a cidadania pelo critério do jus soli. O reconhecimento da cidadania se dava oficialmente quando o jovem completava dezoito anos. Este era apresentado à Assembléia do Demo que, em base a sua ascendência, o reconhecia ou não como cidadão" in DAL RI JúNIOR, Arno, Evolução Histórica... cit, p. 28. Assim também ARISTÓTELES ao afirmar que "[a] mera residência num Estado não confere a cidadania; estrangeiros e escravos não são cidadãos, mas podem morar no país” e mais adiante que "[n]a prática, 
(portanto não era conceito universal nem mesmo dentro da própria sociedade ateniense) como portadores de direitos e obrigações com vistas à participação ativa no processo decisório coletivo, como decisões judiciais e elaboração da legislação, e no preenchimento de cargos públicos.

Esse, outrossim, o conceito de cidadania para ARISTÓTELES, para quem o que “distingue efetivamente o cidadão dos demais é a sua participação no judiciário e na autoridade, isto é, nos cargos públicos e na administração política e legal”39. Em função dessa participação, os cidadãos detêm poder sobre a polis em situação de igualdade com seus semelhantes, ora como legisladores, ora como julgadores, e assim por diante, a que ARISTÓTELES chama de autoridade inespecífica, para defini-los "como aqueles que participam da autoridade inespecífica" ${ }^{\text {40 }}$.

Nesse sentido, em certa medida, seria possível asseverar a existência de uma identidade entre a vontade do cidadão e a vontade do Estado. Daí o entendimento da época de que apenas a vida coletiva na polis permitiria ao indivíduo desenvolver-se plenamente. Porque, nessa concepção, efetivamente livre seria somente aquele capaz de, através da atuação pública, participar da autoridade a que também se submetia. Essa parece ser a percepção de VASCONCELOS ao registrar que "a liberdade do ateniense não era algo que se afirmasse em oposição ao Estado, como nos tempos modernos, mas, antes, a ação política livre só era capaz de realizar-se dentro do Estado e através dele"41.

A conclusão decorrente do exposto, tomada tendo em vista os objetivos deste trabalho, é a de que o conceito de cidadania na maneira ateniense antiga é destituído de uma esfera individual de titularidade de direitos. Como mencionado acima, residentes em Atenas não-cidadãos detinham direitos de cunho individual e, inclusive, conforme anotou ARISTÓTELES $^{42}$, era-lhes viabilizado assegurá-los nos tribunais.

A cidadania ateniense antiga deve, em verdade, ser compreendida sob um panorama essencialmente público, como condição e, também, exigência de participação na

cidadão é aquele que tem pai e mãe cidadãos" in ARISTóteles, A Política, in Aristóteles, col. Os Pensadores, São Paulo, Nova Cultural, 1999, pp. 211 e 213.

${ }^{39}$ ARISTÓTELES , A Política... cit, p. 212.

${ }^{40}$ ARISTÓTELeS , A Política... cit, p. 212.

${ }^{41}$ VASCONCELOS, Arnaldo, A Cidadania ... cit, p. 8.

${ }^{42}$ Aristóteles , A Política... cit, p. 211. 
gestão da coletividade. O cidadão ateniense participava porque assim podia em função de sua condição, mas também, e talvez principalmente, porque devia ${ }^{43}$.

\subsection{A ampliação da noção de cidadania na formação dos Estados nacionais:} um escorço sociológico.

Em vista da grande difusão de sua concepção, bem como da fundamentação histórica que encerra, pode-se tomar como segunda concepção a ser visitada aquela verificada na obra de MARSHALL ${ }^{44}$. A partir da observação do processo de formação moderna da sociedade estatal inglesa, o autor conceitua cidadania através de sua decomposição em três elementos de uma qualidade atribuída ao indivíduo em determinada sociedade: um elemento civil, um elemento político e um elemento social. A incorporação desses elementos ao conceito de cidadania é dividida pelo autor em três momentos históricos (reconhecidamente de forma abstrata, posto que os períodos, como em geral na história, não são estanques): século XVIII, século XIX e século XX.

Assim, segundo MARShALL ${ }^{45}$, é inerente ao elemento civil o conjunto de direitos relativos à liberdade individual: liberdade civil, liberdade de expressão, pensamento e crença, direito à propriedade e de celebrar contratos e direito à prestação jurisdicional (formado, entre outros, pelo direito de defender-se em juízo e pela garantia de acesso aos tribunais para proteção de direitos individuais, sempre em condição de equidade com os demais e através do devido processo legal).

O elemento político equivaleria ao direito de participar do exercício do poder político, tomando parte nos corpos de expressão do poder ou exprimindo a vontade individual para sua composição através do voto.

Por sua vez, o elemento social é composto, na acepção de MARSHALL, pelo rol de direitos sociais: do direito à saúde aos direitos previdenciários, garantidos aos indivíduos e à comunidade segundo uma concepção de dignidade humana (ou mínimo de bem estar) prevalecente em determinada sociedade.

\footnotetext{
43 ARISTÓTELES, todavia, relata com tom de crítica que muitos cidadãos, sobretudo aqueles que viviam no campo, longe dos espaços públicos da polis, não participavam dos assuntos públicos, in ARISTÓTELES, $A$ Constituição... cit.

${ }^{44}$ Marshall, Thomas Humphrey, Ciudadania y Classe Social, in Reis, v. 79, 1997, p. 302.

${ }^{45}$ MARSHALl, Thomas Humphrey, Ciudadania ... cit, p. 302 e 303.
} 
Interessante notar que é inerente ao conceito de MARSHALL uma tendência à universalidade e à uniformização da qualidade de cidadão aos membros de uma sociedade específica, com enfoque sobre o indivíduo, titular de direitos ${ }^{46}$, diferentemente do que ocorre na concepção ateniense. Na acepção grega a abordagem era restritiva (condição de cidadão partilhada por poucos) e com certa inclinação à precedência do público e do comum sobre o privado.

Entende-se neste trabalho, considerando-se seus fins, que este caráter universal e uniforme, ainda que universal deva ser entendido em relação aos súditos de um determinado Estado, é ponto central do esforço de MARSHALl para a conceituação de cidadania.

Isso porque, segundo a interpretação feita nesta pesquisa, MARSHALL não sustenta seu conceito de cidadania em eventual criação ou desenvolvimento de direitos civis, políticos e sociais. Pelo contrário, assevera que tais direitos já existiam, mas como prerrogativas de grupos, sem uniformidade entre eles quanto a seu rol, e amalgamados num só conjunto.

Refere-se à sociedade feudal, em que direitos civis, políticos e sociais mesclados “derivavam do status [do indivíduo, ou seja, do estamento a que pertencia] que também determinava o tipo de justiça que podia conseguir e onde podia consegui-la, e a maneira pela qual podia participar na administração dos assuntos da comunidade da qual era membro" ${ }^{47}$ (tradução livre).

Mas esse status não correspondia ao status ou condição de cidadão na acepção atribuída por MARSHALL à cidadania. Conforme ensina, "[n]a sociedade feudal o status era a marca distintiva da classe e a medida da desigualdade. Não existia nenhum grupo uniforme de direitos e obrigações com que todos os homens - nobres e plebeus, livres ou escravos - estivessem dotados em virtude de seu pertencimento à sociedade" ${ }^{\text {48 }}$ (tradução livre).

\footnotetext{
${ }^{46}$ Em complementação à posição de Marshall, confira-se Turner: "the development of citizenship involves a transition from societies based upon ascriptive criteria to societies based upon achievement criteria, a transition which also involves a shift from particularistic to universalistic values. Thus the emergence of the modern citizen requires the constitution of an abstract political subject no longer formally confined by the particularities of birth, ethnicity or gender." in TURNER, Bryan S., Outline of a Theory of Citizenship, in Sociology, v. 24, n. 2, 1990.

${ }^{47}$ MARSHALl, Thomas Humphrey, Ciudadania ... cit, p. 303.

${ }^{48}$ Marshall, Thomas Humphrey, Ciudadania .... cit, p. 303.
} 
Em seu discurso, esse aspecto fica bem caracterizado na análise da evolução da cidadania em função das lógicas políticas e institucionais distintas existentes na cidade feudal e no Estado nacional. Nesse ponto, importante ressaltar que embora as conclusões de MARShAll sejam passíveis de aplicação à maior parte das sociedades ocidentais, o exame que as fundamentou deu-se especificamente sobre a experiência da Inglaterra. Em verdade, sobre esse aspecto - tratar-se da construção de um conceito através da abordagem do seu desenvolvimento histórico de apenas uma sociedade, TURNER ${ }^{49}$ reúne as principais objeções ao trabalho de MARSHALL, desenvolvendo uma crítica ao caráter unitário de seu tradicional conceito de cidadania.

Paralelamente aos estamentos feudais, regidos pelas conhecidas relações de suserania e vassalagem, compunham, também, a sociedade feudal as cidades, nas quais, segundo MARSHALL ${ }^{50}$, seria possível encontrar exemplos de condições de igualdade de direitos entre indivíduos assemelhadas à sua concepção de cidadania ${ }^{51}$. A diferença estaria no fato de que os direitos assim atribuídos o eram apenas localmente (aos habitantes de determinada cidade), enquanto seu conceito teria por pressuposto inafastável o caráter nacional.

O processo de formação nacional teria, assim, papel decisivo na evolução da cidadania. Elemento de grande relevância nesse desenvolvimento teria sido a reunião da força coercitiva em apenas um centro de poder decisório: o poder real. Esse fato foi decisivo para a definição de significados únicos de titularidade de direitos individuais e para sua defesa. Tais significados são fundamentados em leis e determinações gerais, ou, no caso inglês, na common law britânica, e não nos costumes de determinada localidade.

Segundo MARShALL ${ }^{52}$, na passagem da Idade Média para a Moderna, a consolidação de instituições nacionais especializadas (Tribunais, Parlamentos etc.) segregou o amálgama constituído pelos direitos civis, políticos e sociais, que somente

\footnotetext{
${ }^{49}$ TURNER, Bryan S., Outline of a Theory of Citizenship, in Sociology, v. 24, n. 2, 1990.

${ }^{50}$ Marshall, Thomas Humphrey, Ciudadania ... cit, p. 303.

${ }^{51}$ Cf. aponta TuRner, Max Weber (The City) e Otto Hintze (Historia de las Formas Políticas) localizavam as origens do conceito contemporâneo de cidadania nas imunidades feudais concedidas aos habitantes dos burgos, que muitas vezes organizavam milícias urbanas para sua proteção. No colapso do feudalismo, a autonomia alcançada pelas cidades combinou-se com uma Religião Cristã cada vez mais poderosa politicamente, que impunha a religião comum a todos como base do pertencimento social, em substituição à fundamentação deste em ligações locais tribais, étnicas, corporativistas etc. Na medida em que ampliou o critério de pertencimento através da fé comum, esse novo arranjo certamente contribuiu para a expansão da condição de cidadão, fazendo da cidadania importante elemento na estrutura dos Estados nacionais modernos, cf. TURNER, Bryan S., Contemporary Problems in the Theory of Citizenship, in TURNER, Bryan S (org.), Citizenship and Social Theory, Sage, Londres, 1993, p. 4.

${ }^{52}$ Marshall, Thomas Humphrey, Ciudadania ... cit, p. 304.
} 
voltariam ao mesmo patamar de força no século XX. Além disso, essa mudança aumentou a distância entre o titular do direito e o Estado, em contraposição ao que existia quando esses direitos eram assegurados pela localidade, corporação ou grêmio, o que não poderia ser diferente justamente face ao caráter generalista das determinações das instituições nacionais.

É a história desse reencontro, na mesma situação de força e sob um mesmo titular, que MARShall trabalha quando afirma os períodos de incorporação dos três elementos ao conceito de cidadania (direitos civis, políticos e sociais).

Como mencionado, a primeira fase, atribuída por MARSHALL ao século XVIII, corresponde à afirmação dos direitos civis, processo em que os tribunais cumpriram função essencial, dado seu empenho na defesa da liberdade individual. Na Inglaterra, relata MARSHALL $^{53}$, isso seria expressado por diversos documentos: habeas corpus Act, Tolerance Law e abolição de censura de imprensa, emancipação católica etc. Todas essas medidas expressavam, contudo, um anseio da sociedade inglesa por liberdade individual, cujas grandes manifestações foram as Revoluções Liberais. Essa pretensão social foi absorvida pelos tribunais sob o primado do império da lei geral, igualmente aplicável a todos.

O emblema fundamental dessa primeira fase, no entanto, é a conquista da liberdade individual. Esta deve ser compreendida através da contraposição com os exclusivismos e desigualdades institucionais da sociedade medieval ${ }^{54}$, que essa nova lógica se propunha a extinguir. MARSHALL mostra essa dinâmica em relação ao direito individual de "trabalhar no ofício escolhido, no lugar escolhido, com o único requisito legítimo de domínio prévio de formação técnica"55 (tradução livre). O direito a essa liberdade, explica, teve sua afirmação através do esforço dos tribunais em garanti-lo em face de normas e costumes locais de cunho protecionista e corporativo. São suas palavras: "[o] reconhecimento do direito pressupôs a aceitação formal de uma mudança fundamental de atitude. A velha suposição de que os monopólios locais e de grupo eram de interesse público [...] foi substituída pelo novo pressuposto de que essas restrições eram uma ofensa para a liberdade

\footnotetext{
${ }^{53}$ Marshall, Thomas Humphrey, Ciudadania... cit, pp. 304 e 305.

${ }^{54}$ TURNER aponta, contudo, o trabalho do historiador Otto Hintze, para quem a origem da cidadania poderia ser localizada justamente nas imunidades concedidas a determinados grupos urbanos da sociedade feudal, o que entendia ser um elemento precursor do constitucionalismo moderno, in TURNER, Bryan S., Contemporary Problems in the Theory of Citizenship, in TURNER, Bryan S (org.), Citizenship and Social Theory, Sage, Londres, 1993.

${ }^{55}$ MARShall, Thomas Humphrey, Ciudadania... cit, p. 305.
} 
do indivíduo e uma ameaça para a prosperidade da nação" ${ }^{\text {,5 }}$ (tradução livre). Essa derrubada de restrições locais, associativas e estamentais ocorreu com o direito à liberdade de trabalho, mas se repetiu com diversos outros direitos civis.

MARSHALL notou, nessa tendência, a universalização e a uniformização do status, agora status de cidadão: “[e]ste caráter democrático ou universal do status emergiu naturalmente do fato de que era fundamentalmente o status da liberdade, e na Inglaterra do século XVIII todos os homens eram livres" 57 (tradução livre). A liberdade que os habitantes das cidades medievais gozavam, excluídos dos óbices inerentes à vida no feudo por esse pertencimento a determinada cidade (essa cidadania), alçou caráter de direito geral, estendendo-se a todos os nacionais, membros da sociedade inglesa, qualquer que fosse sua morada. Essa transformação foi decisiva; "[q]uando a liberdade foi universal, a cidadania deixou de ser uma instituição local para converter-se em nacional" (tradução livre).

Em relação aos direitos políticos a evolução seria diferente, uma vez que esse status geral de liberdade desfrutado por todos os nacionais já era realidade. Ademais, direitos de participação política não eram desconhecidos. MARSHALL explica que "no século XVIII os direitos políticos eram defeituosos não em seu conteúdo, mas em sua distribuição - é dizer, defeituosos à luz dos padrões da cidadania democrática"58 (tradução livre).

Assim, pode-se compreender que a história da incorporação dos direitos políticos ao conceito de cidadania, segundo MARSHALL, foi uma história de adaptação aos seus novos padrões universais e uniformes, movida, sobretudo, por reivindicações da classe operária em busca de maior igualdade política, sobretudo um maior acesso ao processo parlamentar $^{59}$. Essa integração, que se estendeu pelo século XIX e alcançou o século XX, foi produto de uma tendência progressiva de se atribuírem direitos de participação política (elegibilidade, ocupação de cargos públicos, extensão do sufrágio) a novos segmentos da população, até que a dimensão de tais direitos alcançasse a extensão do conceito de cidadania, conforme erigido sobre o fundamento da universalização e da uniformização da liberdade.

\footnotetext{
${ }^{56}$ MARShall, Thomas Humphrey, Ciudadania ... cit, p. 305.

${ }^{57}$ Marshall, Thomas Humphrey, Ciudadania ... cit, p. 306.

${ }^{58}$ Marshall, Thomas Humphrey, Ciudadania ... cit, p. 307.

${ }^{59}$ Cf. Turner, Bryan S., Outline... cit., p. 191.
} 
Finalmente, a exposição de MARSHALL acerca dos direitos sociais evidencia uma evolução que se deu como decorrência de uma transformação no sentimento da sociedade em relação a eles ${ }^{60}$.

Entre as instituições do antigo regime na Inglaterra, havia a organização de um sistema de assistência e de regulação salarial cujas origens seriam as relações de caráter gremial nas comunidades locais e associações sociais, com escopo de proteção a seus membros. À medida que os anseios por liberdade universal e uniforme, sobretudo no âmbito econômico, corroem essa velha ordem, esses direitos sociais incipientes são encarados pejorativamente como componentes de um regime exclusivista e estratificado, que não podia mais se sustentar. Nesse curso, eles são vigorosamente afastados do conceito de cidadania que, segundo MARSHALL, se formava.

Assim, os direitos sociais não poderiam ser entendidos como elemento da cidadania porque não encontravam guarida na lógica da transformação política da época, de valorização da liberdade individual econômica, da liberdade de acesso ao trabalho, da liberdade de contratar etc., expressão de um sentimento social desenvolvido justamente em contraposição ao modelo do antigo regime de privilégios de classes e corporações.

MARSHALL afirma que, naquele momento, socorros públicos de cunho social eram oferecidos somente "àqueles que, por doença ou idade, fossem incapazes de seguir pelejando, ou a todos aqueles seres indefesos que renunciavam à luta, reconheciam sua derrota e pediam clemência"61 (tradução livre). Essa renúncia, nessa lógica, era incompatível com a manutenção da condição de cidadania, porque a idéia de assistência pública aos incapazes de prover os próprios meios era considerada indigna por uma sociedade que primava o desenvolvimento social através do máximo desenvolvimento individual.

Asseverou MARShall que "os necessitados perdiam de fato o direito civil da liberdade individual ao entrarem nos asilos de pobres e, por lei, qualquer tipo de direitos políticos que tivessem. [...] O estigma que acompanhava a assistência pública era expressão dos sentimentos profundos de gente que entendia que quem aceitava a

\footnotetext{
${ }^{60}$ Seu paradigma para essa análise é, principalmente, a Poor Law inglesa, sistema de assistência aos pobres e incapazes iniciado já no século XVI e que perdurou, embora com grandes alterações, até a conformação do Estado de Bem Estar Social.

${ }^{61}$ Marshall, Thomas Humphrey, Ciudadania ... cit, p. 309.
} 
assistência devia cruzar a senda que separava a comunidade de cidadãos da companhia dos proscritos da sociedade" ${ }^{\circledR 2}$ (tradução livre).

Contudo, os abusos que esse modelo de exploração do trabalho humano mostrou na sociedade industrial fizeram com que em fins do século XIX e início do século XX essas concepções individualistas já estivessem em muito superadas. Assim, as reformas institucionais que levaram à conformação do Estado de Bem Estar Social permitiram a reconciliação dos direitos sociais com direitos civis e políticos e sua incorporação ao status de cidadão nacional. Conforme afirmam Kymlicka e Norman, "para Marshall, a expressão integral da cidadania requer um estado de Bem Estar Social liberal e democrático"63 (tradução livre).

Entre nós, CARVALHO ${ }^{64}$ registrou postura semelhante ao ensinar que, enquanto a função dos direitos civis é a de propiciar a vida em sociedade (garantida pela difusão indiscriminada da liberdade entre seus membros) e a dos direitos políticos é garantir a participação na gestão dessa organização, a razão de ser dos direitos sociais seria possibilitar a participação na riqueza coletiva. Em suas palavras, "[o]s direitos sociais permitem às sociedades politicamente organizadas reduzir a desigualdade excessiva e garantir a todos um mínimo de bem estar"65 (tradução livre).

Para finalizar a exposição sobre o pensamento de MARSHALL, é importante ressaltar esse caráter nacional. Seu conceito de cidadania refere-se a uma condição atribuída indistintamente aos membros de uma determinada sociedade, relativa à titularidade de todos os seus membros, igualmente, de direitos e deveres por ela selecionados. A universalização desse status seria interna a tal corpo social, ou seja, seria nacional. MARSHALL explica não haver primado universal que arrole taxativamente quais são esses direitos e deveres, cuja seleção dependeria da própria evolução nacional. "[M]as as sociedades em que a cidadania é uma instituição em desenvolvimento criam uma imagem da cidadania ideal com a qual se pode medir o êxito e em função da qual podem dirigir suas aspirações. $\mathrm{O}$ avanço no caminho assim traçado é um impulso em direção a uma medida mais completa de igualdade, um enriquecimento do conteúdo de que é feito esse status e um aumento do número daqueles a quem é outorgado"66 (tradução livre).

\footnotetext{
${ }^{62}$ Marshall, Thomas Humphrey, Ciudadania ... cit, p. 310.

${ }^{63}$ KYMLICKA, Will et NORMAN, Wayne, Return... cit, p. 354.

${ }^{64}$ Carvalho, José Murilo de, Desenvolvimiento de la ciudadanía en Brasil, México, Efe,1995, p. 10.

${ }^{65}$ Carvalho, José Murilo de, Desenvolvimiento ... cit., p. 10.

${ }^{66}$ MARSHALl, Thomas Humphrey, Ciudadania ... cit, p. 312.e 313.
} 
Em relação ao direito à educação, objeto deste estudo, essa medida deverá ser verificada no direito positivo brasileiro a partir das normas constitucionais. Ainda que o conceito adotado para esse esforço não seja exatamente o de MARSHALL, cumpre averiguar de que modo, do ponto de vista jurídico, o país age na concretização da cidadania.

A posição de MARSHALl é representativa de uma postura em relação à concepção de cidadania muito difundida entre os estudiosos do tema no pós-guerra, que KYMLICKA e NORMAN ${ }^{67}$ chamam de concepção ortodoxa.

Em verdade, vale o registro da lição de KYMLICKA e NORMAN, que, no esforço de esquematização acerca da produção teórica sobre cidadania, lecionam ser possível trabalhar, grosso modo, com uma concepção de cidadania enquanto status legal (como é a de Marshall, intimamente ligada à idéia de titularidade individual de direitos) ou com uma concepção de cidadania enquanto atividade. Na primeira, conforme ensina VIEIRA ${ }^{68}$, há uma abordagem individualista do cidadão, titular de direitos em face do Estado, com foco num padrão mínimo de liberdade e igualdade efetiva que lhe é reconhecido pela sociedade pelo simples fato de a ela pertencer. Na segunda, o enfoque é de precedência da comunidade, assemelhado em certa medida ao entendimento grego que via a dedicação ao bem público como dever essencial e primeiro de todo cidadão.

Interessante anotar a interpretação de KYMLICKA e NORMAN acerca da acepção de MARSHALL, que, segundo os autores, define cidadania "essencialmente como uma questão de garantir que todos os indivíduos sejam tratados como membros iguais e integrais da sociedade. E a maneira para assegurar esse sentido de pertencimento é através da atribuição à população de um número crescente de direitos de cidadania",69 (tradução livre). Reconhecidamente, para MARSHALL, a não atribuição dos direitos de cidadania impede que o indivíduo possa participar integralmente da vida em sociedade. A passividade dessa postura está na ausência de qualquer obrigação para essa titularidade, garantida pelo Estado, que permite a participação na vida pública.

Já o conceito de cidadania enquanto atividade, em oposição, está ligado à idéia de que o desenvolvimento e a qualidade de uma sociedade democrática dependem das escolhas e atitudes de seus cidadãos quanto à sua habilidade de promover a formação de um corpo social responsável e tolerante em relação às diferenças, quanto ao seu desejo de

\footnotetext{
${ }^{67}$ KYMLICKA, Will et NORMAN, Wayne, Return... cit, p. 352 a 381.

${ }^{68}$ VIEIRA, Liszt, Cidadania Global e Estado Nacional, in Dados, v. 42, n. 3, 1999 (consulta eletrônica).

${ }^{69}$ KYMLiCKA, Will et Norman, Wayne, Return... cit, p. 354.
} 
participar do processo político para buscar o bem comum, quanto à responsabilidade que apresentam em suas escolhas econômicas individuais etc.

A cidadania na concepção ativa, segundo KYMLICKA e NORMAN ${ }^{70}$, adviria de uma tendência teórica que a enxerga a partir de uma ênfase nas responsabilidades e virtudes que devem ser esperadas do cidadão. Essa posição vem fortalecer a crítica neoliberal à concepção de cidadania aos moldes de MARShALL, sobretudo no que se refere à titularidade de direitos sociais. Seu tom é o de que a atribuição gratuita desses direitos indistintamente a todos teria gerado passividade nos necessitados, criando uma cultura de dependência. Haveria a necessidade de cumprimento de certas obrigações, especialmente em relação ao próprio sustento, para que um indivíduo pudesse ser considerado membro integral de uma sociedade. Atreladas aos direitos assegurados pelo Estado, especialmente os de cunho social, deveriam existir, para essa concepção, obrigações conexas ${ }^{71}$.

Este trabalho, que se propõe à verificação da medida de concretização da cidadania no ordenamento nacional em relação ao direito à educação, um direito de caráter eminentemente social, não adotará um conceito jurídico de cidadania sujeito ao cumprimento de obrigações. Tal concepção teria o estigma de condicionar direitos fundamentais a um rol de deveres que poderia ser ilimitado, uma vez que relacionado a uma compreensão bastante abstrata de o que seja e de qual seja o limite mínimo de dedicação à comunidade e ao bem comum. Admite-se que o enfoque deva se dar sobre o indivíduo, pelo menos do ponto de vista jurídico. Conforme consta no início do próprio texto de KYMLICKA ${ }^{72}$ e NORMAN, embora muitos autores sustentem uma teoria da cidadania com ênfase em responsabilidades e virtudes, poucos propõem que esses elementos devam constituir critérios para revisão do status legal de cidadão. É dizer, a cidadania, como condição jurídica relacionada à titularidade e ao exercício de direitos fundamentais, para a maioria dos autores, não deve ser condicionada ao atendimento de responsabilidades e virtudes institucionalizadas.

\footnotetext{
${ }^{70}$ KYMLICKA, Will et NORMAN, Wayne, Return... cit, p. 353.

${ }^{71}$ Contemporaneamente, Lukes e García também dão ênfase ao aspecto dos deveres e da exigência de contribuição à vida pública. Concebem cidadania como um conjunto de três elementos: "La posesión de ciertos derechos así como la obligación de cumplir ciertos deberes en una sociedad específica; pertencencia a una comunidad política determinada (normalmente el estado), que se há vinculado en general a la nacionalidad; y La oportunidad de contribuir a La vida pública de esa comunidad a través de la participación" in LuKES, Steven e GARCIA, Soledad (org.), Ciudadanía: justicia social, identidad y participación, México, Siglo Veintiuno, 1999, p. 1.

${ }^{72}$ KYMLICKA, Will et NORMAN, Wayne, Return... cit, p. 353.
} 
Cumpre relembrar, todavia, que apesar de a concepção de cidadania de MARSHALL, envolvendo sua formação e os direitos que a compõem, ser amplamente difundida em utilizada nas ciências humanas em geral, ela foi construída a partir da observação de uma sociedade específica, qual seja, a sociedade inglesa. Desse modo, embora a estrutura conceitual de MARSHALl possa ser instrumento de análise da cidadania em outras sociedades, é evidente que o desenvolvimento deste instituto será particular a cada uma delas. Assim, para finalizar, vale o registro da lição de TURNER ${ }^{73}$, que, com o objetivo de contribuir para a formação de uma teoria da cidadania, avalia a construção deste conceito em uma série de sociedades para, esquematicamente, propor quatro possibilidades.

Para sua análise, TURNER utiliza duas variáveis: a primeira denomina de natureza ativa ou passiva da cidadania, à medida que o desenvolvimento desta ocorra a partir da atuação do próprio corpo social (desde baixo) ou através do Estado (desde cima); a segunda consiste na relação do espaço público com o espaço privado em cada sociedade, no sentido de ser favorável ou não à formação de um ambiente de participação política da sociedade.

Com esses elementos o autor identifica quatro arquétipos. O primeiro refere-se às estruturas políticas oriundas de um contexto revolucionário, que TURNER ilustra com a França pós Revolução Francesa. O segundo concerne ao pluralismo liberal, identificado com a experiência norte-americana. O terceiro consiste no que o autor denomina de democracia passiva, relativa à história inglesa descrita por MARSHALL. O quarto, por fim, resume-se no autoritarismo plebiscitário, verificável no fascismo alemão.

Nesse modo de avaliar a cidadania, dois fatores são essenciais: a presença ou ausência de uma luta social, entendida como eventos de reivindicação social que contem com alguma forma de violência ou ameaça de violência como instrumento de pressão; e a atuação do Estado diante dessas reivindicações, ou seja, a maneira como as incorpora institucionalmente ou deixa de incorporá-las.

Como mencionado, na primeira dimensão, TURNER contrasta cidadania ativa e cidadania passiva. Afirma que esta é verificável na tradição alemã, na qual a formação da cidadania e dos direitos que lhes são inerentes foi fruto principalmente da ação estatal. Conforme o autor, "[n]a Alemanha, a ausência de uma revolução burguesa radical bem sucedida e o desenvolvimento do capitalismo desde cima, via legislação Bismarckiana,

\footnotetext{
${ }^{73}$ Cf. TURnER, Bryan S., Outline... cit..
} 
criaram um contexto social no qual as condições para o desenvolvimento de uma noção de cidadania completa e dinâmica fossem limitadas"74 (tradução livre). Nesse contexto, não foi possível desenvolver-se uma concepção de cidadão livre como inquestionável titular de direitos.

Quanto à segunda dimensão de análise proposta, que verifica a prevalência da esfera pública ou da esfera privada, TURNER entende que, por força dos mesmos elementos, também restou subdesenvolvido o espaço público, ou seja, o ambiente adequado para o debate, controle e participação pública da comunidade na gestão dos assuntos estatais. O autor aponta que a moral luterana colaborava para tal organização sócio-política, à medida que consagrava a figura do Estado como representante da comunidade e também como guardião do indivíduo privado e da família.

Nessa estrutura, o foco das preocupações sociais era o espaço individual, cuja proteção era a finalidade primordial do Estado. Este, bem assim o ordenamento jurídico que lhe é inerente, era o detentor da soberania, não diretamente o povo. Nesse sentido, deve-se esclarecer que, justamente pela ausência de uma esfera pública bem desenvolvida e pelo foco na esfera privada, este Estado detentor da soberania, guardião da família e do indivíduo, é visto antes como uma entidade abstrata do que como um corpo de governo democraticamente composto e controlado. Diante dessa transcendência do Estado na titularidade do poder, foi inevitável a subordinação do indivíduo à moral estatal, o que claramente pôde ser percebido na experiência nazista. Conforme esclarece TURNER, a opção totalitarista alemã do século XX pode ser compreendida diante da verificação desse contexto social de espaço de debate público deficiente e de preocupação dos membros da sociedade essencialmente com sua esfera privada, cuja proteção era a principal e mais categórica função do Estado, ao que se somou a derrota alemã na Primeira Guerra Mundial seguida de uma fraca e ineficaz República de Weimar. Segundo o autor, "a visão de Carl Schmitt de que não é responsabilidade do Estado estabelecer consenso com o eleitorado, mas sim de tomar ações firmes e corajosas contra seus inimigos foi conseqüência natural desses desenvolvimentos. Ser livre, do ponto de vista do cidadão individual, era servir ao

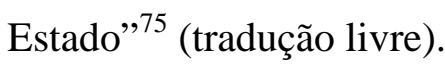

Este é, portanto, o modelo de autoritarismo plebiscitário, de direitos de cidadania conferidos desde cima (cidadania passiva), e no qual é o Estado que controla o espaço

\footnotetext{
${ }^{74}$ TURNER, Bryan S., Outline of a Theory of Citizenship, in Sociology, v. 24, n. 2, 1990, p. 206.

75 TURNER, Bryan S., Outline of a Theory... cit., p. 206.
} 
público, em pese eventual presença de formas democráticas, tais como o periódico sufrágio para escolher líderes e/ou legitimar as decisões estatais.

No modelo da democracia passiva, identificado por TURNER com o caso da Inglaterra, a formação dos direitos de cidadania também possui caráter passivo. Todavia, no que se refere à sociedade civil, o espaço público prevalece sobre o privado, no que difere do arquétipo autoritarista. Assim, nessa democracia passiva reconhece-se a importância legitimadora das instituições representativas, do consenso democrático na produção do direito, dos tribunais para o controle de sua aplicação e de um sistema de bem estar social para resguardo das necessidades públicas. Contudo, embora haja esta participação da sociedade na esfera pública, não existe tradição de conquista de direitos de cidadania através de episódios de luta social.

Conforme já abordado, segundo MARSHALL ${ }^{76}$, na Inglaterra, a transição do sistema feudal de direitos e obrigações divididos em corporações e estamentos para o sistema do Estado nacional de uniformização e universalização dos direitos individuais teve como principal propulsor o sistema de common Law. À medida que as cortes inglesas, nos séculos XVI e XVII, absorvem o primado da liberdade, pelo qual se reconheceu que todo cidadão inglês nasce um homem livre, portanto igual em direitos, prerrogativas feudais tornaram-se direitos de cidadania, agora componentes de uma condição partilhada por todos os nacionais. Além do trabalho dos tribunais, a sociedade inglesa contou também com a progressiva expansão da autoridade parlamentar para a formação da cidadania.

Como se sabe, a história inglesa do período conta com revoluções burguesas no que se refere ao combate ao absolutismo. Todavia, não se deve esquecer que a derrota do antigo regime inglês não significou a ruptura com uma séria de suas instituições, tais como a Monarquia, a Igreja, a Câmara dos Lordes etc. Conforme salienta TURNER, o acordo constitucional que pôs fim à Revolução Gloriosa em 1688 criou, antes de tudo, o cidadão inglês como súdito britânico, cujos direitos individuais inafastáveis são assegurados por um monarca que atua no parlamento. Nas palavras do autor, "[a] noção de cidadão-comosúdito indica claramente a relativamente extensa noção de direitos de cidadania, mas também o caráter passivo das instituições civis britânicas"77 (tradução livre). Contudo, embora marcada por um modelo de cidadania passiva, a sociedade britânica conta com

\footnotetext{
${ }^{76}$ Marshall, Thomas Humphrey, Ciudadania ... cit, pp. 304 e 305.

${ }^{77}$ TURNER, Bryan S., Outline of a Theory of Citizenship, in Sociology, v. 24, n. 2, 1990, p. 207.
} 
antiga tradição de participação política, ou seja, atuação no espaço público, razão pela qual configurou, na visão de TURNER, o modelo de democracia passiva.

Finalmente, as histórias da França e dos Estados Unidos apresentam, respectivamente, os modelos do contexto revolucionário e do pluralismo liberal.

No caso francês, a longa luta contra o absolutismo e a estrutura social rigidamente dividida em estamentos culminou numa violenta transformação da ordem social que produziu uma concepção ativa de cidadania. A sociedade assim transformada passa a ser encarada como um conjunto de indivíduos cuja existência era representada pela vontade geral da Nação exprimida no parlamento.

A base teórica que dava suporte à Revolução Francesa via justamente na cidadania o elemento comum que reunia numa só Nação todos os franceses, não mais súditos de uma soberania monárquica, mas cidadãos iguais de uma mesma entidade nacional.

Assim, conforme ensina TURNER, os teóricos revolucionários do iluminismo francês entendiam que a viabilidade da cidadania dependia do culto à Nação e à República, com a necessária abolição de todas as instituições particulares e locais, como a Igreja, a família, as corporações, que pudessem separar o cidadão do Estado. O efeito desta característica foi uma forte prevalência do espaço público.

Já no caso norte-americano, outro exemplo de forte luta contra um poder arbitrário central, os direitos de cidadania também tiveram seu desenvolvimento dentro de uma concepção ativa. Direitos conquistados e não direitos atribuídos. Como na experiência francesa, essa formação foi impulsionada pela concepção de direitos fundamentais como sendo inafastáveis prerrogativas do cidadão livre. Todavia, segundo TURNER, a grande diferença em relação ao caso francês pode ser encontrada na própria construção dos direitos de cidadania nos Estados Unidos. Neste país, a cidadania definiu-se, eminentemente, diante da tensão que opunha localismo a centralismo.

Conforme ensina TURNER, na tradição norte-americana, "a dominância do individualismo e o [alto] valor do sucesso pessoal significaram que o 'espaço público' fosse comumente compreendido como envolvimento individual em associações voluntárias locais"78 (tradução livre), o que, na visão do autor, representa um espaço público de atividade política deficiente. Ademais, esse foco na esfera privada, que expressa a ênfase

\footnotetext{
${ }^{78}$ TURNER, Bryan S., Outline of a Theory of Citizenship, in Sociology, v. 24, n. 2, 1990, p. 209.
} 
na privacidade, na liberdade individual e na livre opinião, determinou o insucesso no desenvolvimento de um sistema nacional de Bem Estar Social satisfatório.

A verificação dos quatro arquétipos sugeridos por TURNER mostra, com mais intensidade, a diversidade de formas através das quais se pode abordar o tema da cidadania. Como já ressaltado, o tema da cidadania, até por percorrer diversas ciências (política, sociológica, jurídica etc.), é extremamente amplo e complexo.

Há uma interessante lógica na sequiência de formação dos direitos de cidadania apresentada por MARSHALl. Conforme ensina $\mathrm{CARVALHO}^{79}$, uma lógica que reforça o princípio democrático. No primeiro momento, um Judiciário que paulatinamente adquiria independência em relação ao Executivo foi capaz de garantir as liberdades individuais. Em seguida, diante de um cenário de igualdade crescente, bem como da pretensão por assegurar os direitos individuais auferidos, a busca por participação política era desenvolvimento natural. Por fim, estabelecida a técnica democrática e a representatividade das instituições, havia a legitimidade necessária para que o Parlamento pudesse produzir os direitos sociais que coubessem ao Poder Executivo concretizar por meio de prestações positivas.

Mas CARvalHo alerta: essa seqüência lógica, evidentemente, não se repetiu na maioria dos países. Certamente não representa a experiência brasileira ${ }^{80}$. Em verdade, como visto com o relato sobre a análise de TURNER, mesmo na Europa encontram-se desenvolvimentos inteiramente diferentes, haja vista o caso alemão.

Basta a recordação da história brasileira recente, do século $\mathrm{XX}$, para que a complexidade do conceito de cidadania fique escancarada. Como sabido, o período se inicia com uma República recentemente proclamada, porém marcada pela forte dominação de oligarquias regionais. Do ponto de vista social, como acentua CARVALHO ${ }^{81}$, inexistia um sentimento de comunidade ou identidade nacional.

De fato, foram muito raros os momentos da história brasileira que pudessem produzir tal unidade. Após a proclamação da independência em 1822, talvez seja possível identificar apenas a Guerra do Paraguai, que uniu soldados e recursos de todas as províncias no combate contra um inimigo comum ${ }^{82}$. Pelo contrário, o recém terminado

\footnotetext{
${ }^{79}$ Carvalho, José Murilo de, Desenvolvimiento ... cit., p. 163.

${ }^{80}$ Cf. Carvalho, José Murilo de, Desenvolvimiento ... cit., p. 11.

${ }^{81}$ Carvalho, José Murilo de, Desenvolvimiento ... cit., pp. 57 e ss.

${ }^{82}$ Cf. Carvalho, José Murilo de, Desenvolvimiento ... cit., p. 18.
} 
século XIX, sobretudo no período regencial do Império, foi marcado por movimentos emancipacionistas (Confederação do Equador em Pernambuco, Cabanagem no Pará, Sabinada na Bahia, Farroupilha no Rio Grande do Sul etc.).

Na realidade, pode-se afirmar que é a partir de 1930 que a estrutura social e política brasileira começa a se alterar. Nesse aspecto, interessa ressaltar que essa transformação ocorreu num contexto em que a prática democrática foi por duas vezes interrompida por governos ditatoriais e autoritários. De fato, como alerta FAUSTO ${ }^{83}$, o movimento autoritarista da década de 30, concretizado institucionalmente com o Estado Novo em 1937, teve como principal fundamento a necessidade de criação de um sentimento de identidade nacional.

Autores da época, como Azevedo Amaral, Oliveira Viana e Francisco CAMPOS, expoentes do pensamento autoritário brasileiro, foram abundantes em suas críticas ao artificialismo assumido pela democracia liberal implantada no Brasil após a proclamação da República. Sua posição era a de que a história ruralista, oligárquica e regionalista brasileira não permitiu que se desenvolvesse no Brasil uma sociedade solidária, articulada e coesa, diante do que a prática das fórmulas liberais era absolutamente inviável. Propugnavam que o caminho mais eficiente para desenvolver a identidade nacional ausente era através de um Estado forte, com a primazia de um Poder Executivo central. Desacreditavam do sufrágio universal, da representatividade no Parlamento e do sistema partidário. Conforme ensina FAUSTO, para 'criar' a nação brasileira, defendiam que caberia ao Estado centralizado materializá-la e representá-la através de "uma autoridade que se coloque acima das frações partidárias e grupos de qualquer natureza, de modo a poder dirigir a nação do alto, agindo como uma força de agregação e unificação e não como uma força de desagregação e luta" ${ }^{84}$.

Essa foi a doutrina autoritária por trás do Estado Novo (1937-1945). Interessante notar que, a despeito de sua previsão na Constituição brasileira de 1934, de vigência efêmera, foi sob a égide da Constituição de 1937 e do regime autoritário que mais se desenvolveram os direitos sociais. O exemplo mais expressivo é a legislação trabalhista e assistencial, com a edição da Consolidação das Leis do Trabalho em 1943.

Considerada a história brasileira, é possível afirmar que, das três esferas de direitos de cidadania que constam do conceito de MARSHALL, os direitos sociais foram os

\footnotetext{
${ }^{83}$ FAUSTO, Boris, O Pensamento Nacionalista Autoritário, Rio de Janeiro, Jorge Zahar, 2001.

${ }^{84}$ FAUSTO, Boris, O Pensamento Nacionalista Autoritário, Rio de Janeiro, Jorge Zahar, 2001, p. 59.
} 
primeiros a se concretizar. O Decreto-Lei $\mathrm{n}^{\circ} 5.452$, de $1^{\circ}$ de maio de 1943 , conhecido como Consolidação das Leis do Trabalho, continua em vigor e inegavelmente eficaz em larga medida.

Os direitos civis estiveram presentes em todas as Constituições brasileiras desde a Carta Imperial de $1824^{85}$. Contudo, se provavelmente estiveram ineficazes para a maior parcela da população durante toda a história deste país, face às condições sócioeconômicas aqui presentes, certamente não foram observados pelo próprio governo durante os dois períodos ditatoriais enfrentados pelo Brasil (1937-1945; 1964-1985). De modo semelhante, também os direitos políticos sofreram com períodos alternados de avanço e retrocesso.

CARVAlHO $^{86}$ analisa os efeitos dessa inversão, na qual direitos sociais concretizaram-se no mesmo momento em que eram institucionalmente suspensos direitos civis e políticos: os anos de Estado Novo.

A introdução de direitos sociais se deu mediante negociação direta entre a população (sobretudo as classes operárias) e a Administração central, num período em que o Poder Legislativo não tinha função efetiva, logo era incapaz de atuar como instância representativa de mediação. Isso produz na sociedade um sentimento de descrédito pelas instituições parlamentares e, em contrapartida, uma supervalorização do Poder Executivo.

O governo, por um lado opressor e arbitrário, por outro é "um distribuidor paternalista de empregos e favores" ${ }^{, 87}$ (tradução livre). Os direitos de cidadania foram presenteados, portanto, não conquistados. Segundo CARVALHO, essa é a explicação para a tendência brasileira de buscar encontrar um messias político quando se exerce o sufrágio. Daí o sucesso de líderes carismáticos como Getúlio Vargas, Jânio Quadros, Fernando Collor e Luís Inácio Lula da Silva.

Nessa perspectiva, adotando-se a estrutura sugerida por TURNER, poder-se-ia afirmar que o desenvolvimento da cidadania brasileira teve uma natureza claramente passiva. $\mathrm{O}$ arrefecimento dessa tendência talvez tenha se iniciado com os movimentos pela redemocratização do início da década de 1980, com a eleição da Assembléia Constituinte em 1986, com a própria Constituição Federal de 1988 e com as garantias por ela criadas, como a ampliação da atuação do Ministério Público, entre outros aspectos. Todavia,

\footnotetext{
${ }^{85}$ Artigo 179 da Constituição Imperial do 1924.

${ }^{86}$ Carvalho, José Murilo de, Desenvolvimiento ... cit., pp. 164 a 168.

${ }^{87}$ Carvalho, José Murilo de, Desenvolvimiento ... cit., p. 164.
} 
apenas a futura distância histórica permitirá verificar se esses eventos foram suficientes para uma inversão de cidadania passiva para cidadania ativa, ou seja, de direitos presenteados para direitos conquistados.

Do que foi brevemente exposto é possível concluir que, do ponto de vista sociológico, a abordagem do tema da cidadania demanda a interpretação de incontáveis práticas sociais que compõem a história de um país. Esta, inclusive, é a linha do conceito atribuído ao tema por TURNER, para quem cidadania constitui exatamente o "conjunto de práticas (jurídicas, políticas, econômicas e culturais) que definem uma pessoa como membro competente de uma sociedade, e que consequentemente moldam o fluxo de recursos às pessoas e aos grupos sociais" ${ }^{88}$ (tradução livre).

Como entre as práticas mencionadas insere-se a jurídica, o conceito sociológico de cidadania de TURNER é mais amplo que a concepção jurídica do tema, algo que o autor faz questão de frisar para que não se suponha erroneamente que sua análise não recai sobre cidadania apenas enquanto uma coleção de direitos e obrigações.

Esta última constatação remete a um importante cuidado metodológico, qual seja, um estudo jurídico que envolva a cidadania demanda a definição de um pressuposto: qual o significado jurídico de cidadania com que se trabalha. Assim, verificada a multiplicidade de perspectivas com que se pode trabalhar o tema do ponto de vista sociológico, entende-se necessário aprofundar o debate sobre o significado jurídico de cidadania.

\section{3. À procura de um significado jurídico para a cidadania estatal.}

A qualificação estatal inclusa na capitulação deste item não é aleatória. Isso porque se entende, neste trabalho, que embora a proteção internacional dos direitos humanos permita a defesa científica de uma eventual cidadania internacional ou cosmopolita, a efetivação de tais direitos depende de algum tipo de vinculação ao Estado, ainda que essa vinculação advenha de obrigação assumida internacionalmente ${ }^{89}$. Se possivelmente relativa quanto aos direitos civis de prestação negativa, essa é uma necessidade bastante evidente em relação ao direito à educação e, de modo geral, aos demais direitos sociais, uma vez

\footnotetext{
${ }^{88}$ TURNER, Bryan S., Contemporary ... cit., p. 2.

${ }^{89}$ Nesse sentido: Estatuto dos Apátridas (1954) e Estatuto dos Refugiados (1951).
} 
que demandam a organização pelo poder público de complexos sistemas prestacionais para sua efetivação.

É importante retomar a idéia apresentada no item anterior para dar prosseguimento à análise do conceito de cidadania que será adotado como parâmetro neste trabalho.

Nota-se no pensamento político do pós-guerra, organizado com grande influência da própria concretização do Estado de Bem Estar Social, que o significado de cidadania refere-se principalmente à expressão de um critério de pertencimento a uma comunidade politicamente organizada e de titularidade de direitos civis, políticos e sociais.

Essa conceituação foi pensada e desenvolvida dentro de um contexto de ciência política e sociológica. Nesse âmbito, também, foi e ainda é questionada. Mencionou-se, ao se comentar KYMLICKA e NORMAN, a objeção feita pela direita neoliberal no sentido de que o conceito de cidadania deve incorporar uma exigência de satisfação de determinadas virtudes e obrigações. Comentou-se, contudo, que os próprios KYMLICKA e NormAN refutam a caracterização dessas exigências como elementos de um status jurídico de cidadania. Entende-se, conforme afirmado acima, que esse tratamento poderia ter resultados bastante perigosos quanto à negação do status de cidadão aos membros da sociedade, e os efeitos que isso teria sobre os direitos fundamentais.

Entretanto, a compreensão que esta pesquisa dá ao tema permite avaliar que também as conceituações sociológicas de MARSHALL ou de TURNER devem ser objeto de análise receosa se a interpretação que lhes for dada visar eleger uma conceituação jurídica de cidadania, ou seja, que possa ser trabalhada dentro do universo do direito.

A incerteza a se opor é que, talvez, numa análise jurídica, a cidadania nacional não signifique propriamente a titularidade de direitos civis, políticos e sociais, mas sim um dado anterior (ou posterior). Para esclarecer essa ponderação, adota-se, primeiramente, o valioso fundamento da obra de LAFER $^{90}$.

A análise se dá em torno de uma triste experiência da humanidade que se passou em território europeu ao longo do período que compreende as duas grandes guerras do século XX: as mazelas enfrentadas pelos apátridas e pelas minorias. Nesse período, conforme relatou ARENDT, a evolução política e institucional das circunstâncias fez com

\footnotetext{
${ }^{90}$ LAFER, Celso, A Reconstrução dos Direitos Humanos: um diálogo com o pensamento de Hannah Arendt, São Paulo, Companhia das Letras, 2006.
} 
que esses dois grupos acabassem perdendo "aqueles direitos que até então eram tidos e definidos como inalienáveis, ou sejam, os Direitos do Homem" $"$.

Como se sabe, a origem desse problema específico está na tentativa mal sucedida dos Tratados de Paz posteriores à Primeira Guerra Mundial de pacificar a Europa oriental e do sul através da criação de novos Estados nacionais em áreas em que, nas palavras de ARENDT, "nem sequer existiam as condições básicas para o surgimento de Estados-nações, ou seja, a homogeneidade da população e a fixação ao solo",92.

Sabe-se, também, que com o apoderamento de governos totalitários, a prática em relação a apátridas e minorias foi a desnacionalização e a supressão da cidadania. Suprimidos os vínculos com o Estado de origem (ainda que uma origem meramente jurídica e não étnica ou cultural), essas pessoas dificilmente encontravam acolhida em outra parte, vale dizer, perdiam o status de nacional e de cidadão de um Estado e raramente logravam repô-lo com o de outro.

Em linhas gerais, essa é a situação objeto da avaliação de ARENDT, analisada e esclarecida por LAFER, que termina com a conceituação de cidadania (entende-se que do ponto de vista jurídico) como um direito a ter direitos.

O calvário dos apátridas e das minorias, esbulhados em todos os sentidos, criou a necessidade de enfrentamento da extensão do vínculo realmente existente entre a outorga de direitos humanos e a manutenção da condição de cidadão. Nesse sentido, BOBBIO falou da perda da certeza de "Kant, e em geral da Era das Luzes"93 acerca dos direitos inatos $e$ adquiridos pela mera condição humana que as duas grandes guerras do século XX causaram à humanidade, retornado o tema à atenção principal das ciências jurídica, filosófica, política etc.

\footnotetext{
${ }^{91}$ ARENDT, Hannah, As Origens do Totalitarismo: Imperialismo, a Expansão do Poder, Rio de Janeiro, Documentário, 1976, p. 201.

${ }_{92}$ ARENDT, Hannah, As Origens...cit., p. 203.

${ }^{93}$ BоввIO asseverou: "[n]o caminho inexorável e irreversível da humanidade em direção ao progresso, nós, homens viventes e pensantes do final de um século que conheceu duas guerras mundiais, não temos a mesma certeza de Kant, e em geral da Era das Luzes. Aprendemos que a história humana é ambígua e pode ser interpretada de diferentes modos, segundo quem a interpreta e segundo o seu ponto de vista. Considerava-se que o progresso científico e o progresso moral avançassem lado a lado. Hoje, sobre o progresso triunfante da ciência e da técnica, não temos dúvidas. Sobre o concomitante progresso moral, ao contrário, seria melhor suspender qualquer juízo. E contudo, nunca como nos últimos anos, em especial depois da Segunda Guerra Mundial, o tema dos direitos do homem, de cuja afirmação Kant deduzira o motivo para acreditar no progresso moral da humanidade, foi novamente reproposto à atenção da opinião pública mundial" in BOBBIO, Norberto, Teoria Geral da Política: A Filosofia Política e as Lições dos Clássicos, Rio de Janeiro, Campus, 2000, p. 476.
} 
Como esclarece LAFER ${ }^{94}$, a supressão do status de cidadão provocou duas ordens de resultados ao indivíduo assim diminuído: a perda da condição que o vinculava ao Direito Internacional Público, uma vez que sua lógica, naquele momento, era a da proteção diplomática, estabelecida em função da nacionalidade, tendo em vista compromissos assumidos entre Estados, sujeitos, por excelência, daquela esfera jurídica; e a perda parelha da circunstância que o conectava à ordem jurídica de seu próprio Estado.

De modo que a pessoa nessa situação encontrava-se à margem de qualquer ordem jurídica, incapacitada de acessar direitos e desprotegida de qualquer tutela. A cidadania nesse contexto tinha o caráter de vínculo jurídico que expressava o pertencimento a toda organização política então conhecida. O indivíduo que a perdia deparava-se com a situação de não pertencer à sociedade politicamente organizada em que havia nascido, nem tampouco a qualquer outra. Não podia, também, pertencer à organização política supranacional, uma vez que esta não estava estruturada para lidar com pessoas que não fossem também nacionais.

Permaneciam, assim, os apátridas, numa condição de exclusão, de anomalia, já que por toda parte o mundo encontrava-se organizado jurídico-politicamente. Sua única alternativa seria que lhes fossem oferecidos novos vínculos, representados pela cidadania de outra organização jurídico-política, vale dizer, outro Estado nacional.

Os efeitos dessa situação esclarecem-se, em certa medida, considerando-se o conceito de MARSHALL ${ }^{95}$ à cidadania: condição à qual são inerentes três esferas de direitos, i. e., direitos civis, políticos e sociais, uniformemente distribuídos a todos pela simples razão de pertencerem a uma determinada sociedade. Mas a incerteza é: quais as implicações ao conceito se esse pertencimento é quebrado?

Daí a importância de se ter claro o prisma sob o qual é avaliado esse pertencimento. Porque, grosso modo, poderia ser entendido sob o prisma sociológico como expressão de uma comunhão de história, cultura, moral etc. ${ }^{96}$. Mas também pode ser concebido, e assim

\footnotetext{
${ }^{94}$ LAFER, Celso, A Reconstrução... cit., p. 146.

${ }^{95}$ Marshall, Thomas Humphrey, Ciudadania... cit.

96 A avaliação de CARVALHO, expressando a preocupação com a avaliação sociológica, é esclarecedora: "diría yo que ciudadanía es más que una colección de derechos, y que el ciudadano no es meramente uma percha donde se cuelgan derechos civiles políticos y sociales. Ciudadanía es también la sensación de pertenecer a una comunidad, de participar de valores comunes, de una história común, de experiencias comunes. Sin esse sentimiento de identidad coletiva - que conferen la lengua, la religión, la historia - no sería posible la existencia de naciones democráticas modernas. La identidad nacional casi siempre se halla estrechamente vinculada a los derechos, sobre todo a los civiles. Pero es más que la suma de los derechos, es
} 
também rompido, juridicamente, significando um vínculo institucionalmente previsto no ordenamento nacional, que pode coincidir ou não com o pertencimento sociológico. Evidentemente, não se desconhece que nas situações das duas grandes guerras do século XX apátridas e minorias geralmente ${ }^{97}$ constituíam parcelas da população que justamente não partilhavam das mesmas raízes étnicas, culturais, históricas, entre outras, que os grupos no poder daqueles Estados nacionais. Em verdade, foi essa condição de diferença sociologicamente verificável que levou, na maior parte dos casos, ao rompimento do vínculo jurídico ${ }^{98}$.

Contudo escolhe-se analisar a questão da cidadania exclusivamente quanto às suas implicações jurídicas, o que pressupõe uma abordagem especificamente sobre o vínculo jurídico criado pelo atributo da cidadania e seu conteúdo.

No caso dos apátridas, LAFER $^{99}$ expõe que o rompimento desse pertencimento a uma organização política, juridicamente determinado pelo Estado através da supressão da cidadania e da desnacionalização, significou para aquelas pessoas a expulsão do amparo do princípio da legalidade. Assim, se a titularidade de direitos humanos é conferida pelo pertencimento, estar fora da sociedade politicamente organizada em absoluto era estar desprovido de qualquer tutela (lembrando que o estrangeiro poderia não pertencer ao Estado em que se encontrava, mas mantinha o vínculo com o seu, e assim era protegido pela lógica diplomática então vigente no Direito Internacional Público).

Essa situação, conforme a exposição de LAFER $^{100}$, é diferente daquela do cidadão nacional que tem seus direitos humanos cerceados, já que a privação de um direito pressupõe a prévia existência do próprio direito. Na estrutura do entre guerras, essa não é a situação do apátrida, para quem os direitos nem mesmo existem.

como la argamasa que une entre sí a los individuos y mantiene unida a la comunidad en momentos de crisis" in CARVAlHo, José Murilo de, Desenvolvimiento ... cit., p. 11.

${ }_{97}^{9}$ Sabe-se da supressão da cidadania de outros grupos como homossexuais e comunistas.

98 ARENDT relatou o ódio que transformou mesquinhas querelas nacionalistas num gravíssimo problema humanitário: “[o] ódio, que certamente não faltara ao mundo, antes da guerra começou a desempenhar um papel central nos negócios públicos de todos os países, de modo que o cenário político, nos anos enganadoramente calmos da década de 20, assumiu uma atmosfera sórdida e estranha de briga de família à la Strindberg. Nada talvez ilustre melhor a desintegração geral da vida política do que esse ódio universal vago e difuso de todos e de tudo, sem um foco que lhe atraísse a atenção apaixonada, sem ninguém que pudesse ser responsabilizado pelo estado das coisas - nem governo, nem burguesia, bem potência estrangeira. Partia consequentemente em todas as direções, cega e imprevisivelmente, incapaz de assumir um ar de indiferença sadia em relação a coisa alguma sob o sol. Essa atmosfera de desintegração, embora característica de toda a Europa entre as duas guerras, era mais visível nos países derrotados que nos vitoriosos[...] Agora todos estavam contra todos, e, mais ainda, contra os seus vizinhos mais próximos - os eslovacos contra os tchecos, os croatas contra os sérvios, os ucranianos contra os poloneses" in ARENDT, Hannah, As Origens...cit., p.200.

${ }^{99}$ LAFER, Celso, A Reconstrução... cit., p. 147.

${ }^{100}$ LAFER, Celso, A Reconstrução... cit., p. 147. 
Talvez seja possível compreender esse episódio como um desvirtuamento da própria construção conceitual de cidadania moderna. Recorde-se, novamente, o trabalho de MARSHALL, que mostra essa formação como um dado inerente à luta contra os privilégios feudais e ao processo de formação do Estado nacional moderno, estendendo-se à integralidade dos membros do corpo social uma condição de liberdade que era justamente criada e garantida pelo império da lei uniformemente posta para todos. Difundida a legalidade, uniformizaram-se as relações dos membros da sociedade com o poder.

A experiência dos apátridas desafiou esse desenvolvimento teórico e histórico ao negar da forma mais básica a igualdade ${ }^{101}$.

Como mencionado acima, na Atenas de Aristóteles, não-cidadãos eram, até certa medida, abrigados na ordem jurídica. Por exemplo, em relação ao seu direito de celebrar contratos comerciais e mesmo de buscar resguardo de suas prerrogativas junto aos tribunais. Mas tendo a cidadania chegado aos limites do ordenamento, como sugeriu MARShall, ao ponto de se identificar com a extensão dos direitos nele previstos, a retrocessão foi traumática.

Ao privar alguns indivíduos do convívio comum, excluindo-os da ordem jurídica, a sociedade ocidental criou uma categoria de pessoas supérfluas, destituídas de direitos, devolvidas ao seu estado de natureza, conforme ensina LAFER ${ }^{102}$. Assim fazendo, atacou um de seus principais fundamentos: a pessoa humana como valor-fonte de todos os demais valores.

Foram tais constatações que levaram à conclusão de HANNAH ARENDT, exposta por LAFER $^{103}$, no sentido de que a cidadania constitui condição de existência dos direitos humanos, ou seja, um direito a ter direitos. Com efeito, o primeiro deles. Nesse raciocínio, a destituição da cidadania, ao retirar o sujeito do ambiente público, relega-o exclusivamente à sua esfera privada, onde não há direitos, "pois estes só existem em função da pluralidade dos homens, ou seja, da garantia tácita de que membros de uma comunidade dão-se uns aos outros" ${ }^{104}$. Em vista disto, esclarece o autor que direito a ter

\footnotetext{
${ }^{101}$ Acerca do assunto, confiram-se as palavras de FERRAJOLI: "Así como la paridad de derechos genere un sentido de igualdad basado en el respeto del otro como un igual, la desigualdad en su titularidad produce una imagen del otro como diferente, como alguien que debe ser antropológicamente inferior porque lo es legalmente" in Ferrajoli, Luigi, Más Allá de la Soberanía y la Ciudadanía: un Constitucionalismo Global, in Isonomía, n. 9, 1998, p. 182.

${ }^{102}$ LAFER, Celso, A Reconstrução... cit., p. 150.

${ }^{103}$ LAFER, Celso, A Reconstrução... cit.

${ }^{104}$ LAFER, Celso, A Reconstrução... cit., p. 152.
} 
direitos "significa pertencer, pelo vínculo da cidadania, a algum tipo de comunidade juridicamente organizada e viver numa estrutura onde se é julgado por ações e opiniões, por obra do princípio da legalidade" ${ }^{\prime 105}$.

Ocorre que exatamente por esse caráter essencial, sustenta LAFER $^{106}$, essa condição de beneficiamento do princípio da legalidade não pode, após o exemplo do período que compreende as duas grandes guerras do século XX, continuar objeto de tratamento exclusivamente interno aos Estados nacionais. Deve, paralelamente (ou, arrisca-se, primeiramente) ser resguardada pelo Direito Internacional Público. O tema dos direitos fundamentais fica, assim, livre da discricionariedade dos governos nacionais, marcados pela obediência à "lógica de seus interesses conjunturais""107, conforme aponta AMARAL JÚNIOR. Felizmente, a experiência dos apátridas ensejou esse movimento, talvez iniciado com a criação da Organização das Nações Unidas e a Declaração Universal dos Direitos Humanos ${ }^{108}$, fortalecido com o Estatuto dos Refugiados de 1951 e dos Apátridas de 1954, mas que certamente ainda ocorre.

E essa pretensão de transferência da tutela ao âmbito internacional, especialmente em matéria de direitos humanos, substituiu a lógica da proteção diplomática, baseada na competência dos Estados para agir no âmbito do Direito Internacional Público, pela lógica da proteção internacional cujo foco na pessoa é cada vez maior, sobretudo nas esferas regionais de proteção.

FERRAJOLI aborda essas alterações afirmando que permitem verificar uma modificação de paradigma no Direito Internacional, que transformou um "sistema contratual baseado em relações bilaterais e iguais entre Estados soberanos em uma verdadeira ordem jurídica de caráter supranacional"109 (tradução livre).

\footnotetext{
${ }^{105}$ LAFER, Celso, A Reconstrução... cit., p. 154.

${ }^{106}$ LAFER, Celso, A Reconstrução... cit., p. 154.

107 Amaral JúnIOR, Alberto do, O Direito de Assistência Humanitária, Rio de Janeiro, Renovar, 2003, p. 116.

108 Sobre o tema, assim registra Amaral Júnior: “[a] experiência dramática da II Guerra mundial proporcionou mudanças significativas no campo dos direitos humanos. Os horrores do conflito trouxeram à baila a necessidade de proclamar direitos, e também de garantir a sua aplicação. O preâmbulo da Carta da ONU enfatizou a importância dos direitos fundamentais do homem, da dignidade do valor do ser humano, da igualdade de direitos dos homens e das mulheres, enquanto nada menos do que seis artigos da Carta se referem expressamente aos direitos humanos. Os direitos humanos integram assim as finalidades da ONU, e o desrespeito aos artigos que os consagram importa na violação da própria Carta das Nações Unidas" in AMARAL JÚNIOR, Alberto do, O Direito... cit., p. 108.

${ }^{109}$ Ferrajoli, Luigi, Más Allá de... cit., p. 177.
} 
Em verdade, esse autor chega a importantes conclusões acerca da concepção de cidadania, cujo registro é imperativo ${ }^{110}$.

Segundo FERRAJOLI ${ }^{111}$, o conceito tradicional de cidadania, assim como ocorre com a noção soberania ${ }^{112}$, constitui idéia ligada estruturalmente ao Estado-Nação ${ }^{113}$. À medida que esta idéia depara-se com profundos desafios, também o conceito de cidadania enfrenta severa contestação, enquanto condição subjetiva de pertencimento a uma comunidade política. A tese do autor é que as mudanças inerentes ao que se poderia denominar crise do Estado-Nação, que tem como um de seus principais aspectos a transformação do paradigma de proteção internacional, perturbaram clássicas posturas conceituais Estadocêntricas sobre o direito, ensejando sérias antinomias entre, de um lado, concepções tradicionais de soberania e cidadania e, de outro lado, constitucionalismo e direitos humanos.

Acerca do tema soberania, FERRAJOLI trabalha com uma dicotomia entre soberania interna e soberania externa. Sobre a primeira, nota um processo de progressiva limitação, iniciado com o fim do absolutismo monárquico e com o nascimento do Estado Liberal. Assim, em suas palavras, "[a] divisão de poderes, o princípio da legalidade e os direitos fundamentais [afirmados a partir daquele momento] representavam tantas limitações e, em última instância, negações da soberania interna, que a relação entre o Estado e o cidadão transformou-se na relação entre dois sujeitos com soberania limitada"114 (tradução livre).

Diferentemente, a soberania externa fortaleceu-se ao longo do século XIX e início do século XX a tal ponto que a comunidade de Estados soberanos pudesse ser entendida como um verdadeiro estado de natureza, já que não há sua sujeição a nenhum comando organizativo.

Interessante a observação de que esses dois processos ocorreram de forma simultânea e condicionada. A auto-sujeição do Estado aos limites da legalidade no plano

\footnotetext{
${ }^{110}$ Ver FerRAJOLI, Luigi, Derechos y garantías. La ley del más débil, Madri, Editorial Trotta, 1999, pp. 97 a 123.

${ }^{111}$ FerRaJoli, Luigi, Más Allá de... cit., p. 173.

${ }^{112}$ Sobre o tema da soberania ver FERRAJOLI, Luigi, A Soberania no Mundo Moderno, São Paulo, Martins Fontes, 2002.

${ }^{113}$ Nesse sentido, confira-se CORTiNA: "Aunque las raíces de la ciudadanía sean griegas y romanas, el concepto actual de ciudadano procede sobre todo de los siglos XVII y XVIII, de las revoluciones francesa, inglesa y americana y del nacimiento del capitalismo. La protección de los derechos naturales de la tradición medieval exige la creación de un tipo de comunidad política - el Estado nacional moderno - que se obliga a defender la vida, la integridad y la propriedad de sus miembros. Con la aparición del Estado moderno se va configurando el actual concepto de ciudadanía, ligado en principio a los dos lados de la expresión 'estado nacional', 'Estado' y 'nación'" in CORTINA, Adela, Ciudadanos del mundo. Hacia una teoría de la ciudadanía, Madrid, Alianza, 1999, pp. 55 e 56.

${ }^{114}$ Ferrajoli, Luigi, Más Allá de... cit., p. 174.
} 
interno, produzidos de forma cada vez mais democrática e representativa, conferiu-lhe legitimidade para absolutizar a natureza de suas decisões. Esse fenômeno, segundo FERRAJOLI $^{115}$, permitiu, pela via do positivismo, que o Estado (não determinado poder ou sujeito, mas toda a organização) afirmasse-se como entidade auto-suficiente, identificada com o direito e, portanto, não sujeita a determinações exógenas. Assim, conforme enfraquecia-se a soberania interna, fortalecia-se a externa.

Foi essa absolutização que desafiou o caráter universal dos direitos humanos. Embora proclamados de caráter universal desde a Declaração francesa de 1789, a existência dos direitos fundamentais ficava sujeita às contingências das ordens internas de cada país com o entendimento de que a produção e a atribuição de qualquer direito encerravam-se no Estado (comunidade política juridicamente organizada em função da legalidade), já que não havia o que o precedesse.

Desse modo, FERRAJoli leciona que ser pessoa deixaria de constituir condição suficiente para a titularidade de tais direitos. Verificou-se essa situação com os apátridas e o autor afirma que ela persiste na atualidade com a questão do afluxo de imigrantes nos países europeus. Nesse contexto, a cidadania perde sua condição de fundamento de igualdade, conquistada na luta contra o absolutismo, para adquirir propósito inverso. "Enquanto internamente a cidadania fracionou-se em diferentes tipos de cidadanias desiguais correspondentes a novas diferenças de status que vão de cidadãos plenos a semicidadãos com direito de residência, refugiados e imigrantes ilegais, no plano externo funciona como um privilégio e uma fonte de exclusão e discriminação em relação aos nãocidadãos" ${ }^{116}$ (tradução livre).

Mas a mudança de paradigma na proteção internacional, que abandona a idéia de nacionais e de modo crescente converge para o resguardo da pessoa, cujo início poderia ser simbolizado com a Carta das Nações Unidas de 1945 e com a Declaração Universal dos Direitos do Homem de 1948, veio pôr à prova o absolutismo da soberania externa bem como a concepção de cidadania como pressuposto de titularidade de direitos humanos.

FERRAJOLI ${ }^{117}$ propõe que esses dois documentos, pelo menos num plano normativo, iniciaram uma transformação na ordem jurídica mundial, levando a Sociedade de Nações do estado de natureza para o estado civil, com base na sujeição de todos os países a duas normas fundamentais: a manutenção da paz e a imperatividade dos direitos humanos.

\footnotetext{
${ }^{115}$ FerRAJOLI, Luigi, Más Allá de... cit., p. 175 e 176.

${ }^{116}$ Ferrajoli, Luigi, Más Allá de... cit., p. 176.

${ }^{117}$ Ferrajoli, Luigi, Más Allá de... cit., p. 177.
} 
Estes, a nova estrutura teria extravasado dos limites da proteção nacional, transformandoos em direitos de titularidade supra-nacional, que limitam o exercício do poder estatal não mais apenas na esfera interna, enquanto previsão jurídica no ordenamento nacional, mas como restrições impostas desde fora aos Estados.

Assegurados universalmente a partir do nível internacional, os direitos fundamentais não comportariam mais a cidadania estatal - como vínculo jurídico do indivíduo ao Estado - como pressuposto de sua existência. Isso leva FERRAJOLI a trabalhar com uma idéia de cidadania de caráter global: "[s]e a subjetividade legal consiste em ser portador de direitos e a cidadania implica que somente se podem exercer direitos através do pertencimento a uma determinada comunidade política, no novo paradigma todo ser humano é, por si, sujeito de direito internacional e portanto é cidadão não apenas de um Estado determinado mas também das comunidades internacionais, sejam regionais, como a União Européia, ou de caráter global, como as Nações Unidas"118 (tradução livre).

Esse entendimento pressupõe uma postura em relação ao quadro normativo internacional acerca dos direitos humanos que reconheça, nas diversas declarações, pactos e convenções que o compõem, um caráter efetivamente imperativo. Em alusão à obra de Ronald Dworkin (Taking Rights Seriously), FERRAJOLI ${ }^{119}$ assevera que levar esses direitos humanos internacionalmente previstos a sério significa desvinculá-los da noção de cidadania enquanto pertencimento a uma comunidade política específica e de seu caráter estatal.

\subsection{O conteúdo do inciso II do artigo $1^{\circ}$ da Constituição Federal de 1988:} cidadania como exigência de efetivação de direitos fundamentais.

Ao sistema internacional de proteção aos direitos humanos, comentado logo acima, faltam, para a concretude do caráter cogente de suas normas, as garantias institucionais que possibilitem às pessoas ofendidas valerem-se de seu resguardo de modo direto, assegurando-se mecanismos eficazes de sujeição dos Estados às decisões tomadas. Seu desenvolvimento, inclusive, colocar-se-ia como um imperativo de desenvolvimento jurídico-institucional global, ainda que, em certa medida, já iniciado no âmbito regional, a

\footnotetext{
${ }^{118}$ Ferrajoli, Luigi, Más Allá de... cit., pp. 177 e 178.

${ }^{119}$ FerRAJOLI, Luigi, Derechos y garantías. La ley del más débil, Madri, Editorial Trotta, 1999, p. 117.
} 
exemplo da Corte Interamericana de Direitos Humanos, do Tribunal europeu de Direitos Humanos, etc.

Todavia, deve-se admitir, como faz FERRAJOLI ${ }^{120}$, que a ausência de tais garantias, como instrumentos a permitir o acionamento dos direitos fundamentais, não os esvazia de seu conteúdo, mas, antes, impõe à sociedade global o dever de criá-las.

No entanto, embora neste trabalho tenda-se à admissão das considerações de FERRAJOLI em sua integralidade, entende-se, também, que a dimensão do Estado, assim como a da cidadania estatal, não pode ser desconsiderada nem sequer relegada a segunda importância no atual estágio de desenvolvimento global. Isso porque, conforme sublinha RANIERI, ainda persiste "o papel primordial do Estado contemporâneo como instância de mediação interna e externa na defesa da pessoa humana"121 . Ademais, como mencionado anteriormente, essa é uma realidade bastante intensa em relação aos direitos fundamentais de cunho social, que demandam prestações positivas pelo Estado, muitas vezes ligadas à organização de complexas estruturas institucionais, como é o caso de um sistema de ensino.

Neste estágio de desenvolvimento da comunidade internacional, simplesmente negar função à cidadania estatal seria suspender a resolução de problemas relacionados à efetividade de direitos fundamentais pelo período necessário à organização de garantias institucionais no plano internacional, capazes de retirar o constitucionalismo global de que fala FERRAJOLI ${ }^{122}$ do estágio embrionário em que se encontra.

Assim, deve-se buscar uma concepção que busque aliar um suporte fático (imperatividade da figura do Estado) a uma postura diante do quadro normativo internacional que o perceba cogente e não como abstração vaga. Este é o propósito da apresentação que iniciou com a origem grega do conceito de cidadania, percorreu algumas das principais concepções sociológicas do tema e terminou imputando-lhe um recente caráter cosmopolita.

\footnotetext{
${ }^{120}$ Ferrajoli, Luigi, Más Allá de... cit., p. 178.

${ }^{121}$ RANIERI, Nina Beatriz Stocco, Estado e Nação: Novas Relações, in Revista do Instituto dos Advogados de São Paulo, n. 13, 2004, p. 272.

${ }^{122}$ Ferrajoli, Luigi, Más Allá de... cit., p. 178.
} 
Diante de tudo isso, atribui-se à cidadania nacional (estatal) o significado de pressuposto não de titularidade, que teria extravasado a esfera nacional, mas de exercício de direitos humanos, porque este permanece na esfera nacional ${ }^{123}$.

Nessa perspectiva, um esclarecimento é imprescindível. Tomado como pressuposto com o qual conta todo participante da sociedade, cujo conteúdo indica uma exigência de máxima fruição de um rol de direitos fundamentais, o conceito de cidadania abrange o exercício dos direitos políticos, e, portanto, não se restringe a eles ${ }^{124}$.

Com efeito, conforme salienta MARTINES ${ }^{125}$, a dimensão dos direitos políticos é de importância extraordinária, uma vez que é a que mais claramente permite ao indivíduo expressar o seu pertencimento a determinada sociedade. Todavia, a redução a esse aspecto importaria um estreitamento indesejado do conceito, sob o risco de se perder a extensão que a própria Constituição Federal de 1988 procurou atribuir-lhe ao elevá-lo, no artigo $1^{\circ}$, inciso II, a fundamento da República. Sobre a cidadania, na lição de MARTINES, “como se cuida de dispositivo constitucional que irradia efeitos em todo o ordenamento jurídico, é necessário emprestar-lhe o maior alcance possível"126.

Vale registrar que essa opção de dar realce à noção de cidadania é novidade do texto constitucional de 1988. Não é da tradição constitucional brasileira enfatizar de forma destacada essa expressão com tal relevância como a de consubstanciar uma das bases sobre as quais a República brasileira encontra suporte.

A Constituição Imperial de 1824 afirmou em seu artigo $1^{\circ}$ que o Império do Brazil é a associação Politica de todos os Cidadãos Brazileiros. Elles formam uma Nação livre, e independente, que não admitte com qualquer outra laço algum de união, ou federação, que se opponha á sua Independencia. Seus artigos $6^{\circ}$ e $7^{\circ}$, por sua vez, respectivamente, estabeleciam as condições para alguém ser considerado cidadão brasileiro ou perder essa condição $^{127}$.

\footnotetext{
${ }^{123}$ Sobre o tema, ver BITTAR, Eduardo Carlos Bianca, Cidadania: condição de exercício dos direitos humanos, in Panóptica, a. 1, v.1, 2006.

124 Para uma visão contrária, entendendo que a universalização dos direitos fundamentais relegou à concepção de cidadania apenas os direitos políticos, o que tornaria impositivo a caracterização de uma concepção de nacionalidade que abranja os demais direitos, confira-se CoRrAL, Benito Aláez, Nacionalidad y Ciudadanía ante las Exigencias del Estado Constitucional Democrático, in Estudios Políticos, n. 127, 2005.

125 Martines Júnior, Eduardo, Educação, Cidadania e Ministério Público - O art. 205 da Constituição e sua Abrangência, Tese (Doutorado) - Pontifícia Universidade Católica, São Paulo, 2006 , p. 204.

${ }^{126}$ Martines JúnIOR, Eduardo, Educação, Cidadania... cit., p. 205.

127 Art. 6. São Cidadãos Brazileiros
} 
A partir desses dispositivos, percebe-se que o texto constitucional imperial concebia cidadania como um conceito muito próximo, senão equivalente, ao de nacionalidade. De fato, Pimenta Bueno, ao comentar os artigos $6^{\circ}$ e $7^{\circ}$ da Constituição Imperial, capitula-os como regras de fixação de nacionalidade, fazendo diferença entre o simples nacional (mero cidadão) e o nacional titular de direitos políticos (cidadão ativo). Afirmava o jurista em seus comentários: "[a] qualidade de nacional ou brasileiro adquirese pois segundo a lei civil e é distinta da de cidadão ativo; dizemos ativo para diferençar de simples cidadão, que é sinônimo de nacional" ${ }^{\text {128 }}$.

A Constituição republicana de 1891 também traz o conceito de cidadania como análogo às noções de nacionalidade e titularidade de direitos de participação política. $\mathrm{Na}$ Seção I (Das Qualidades do Cidadão Brasileiro) do Título IV (Dos Cidadãos Brasileiros) aquela Constituição definia aqueles que podia ser considerados cidadãos (nacionais) brasileiros $^{129}$, identificava dentre estes quais eram titulares de direitos políticos ${ }^{130}$ e como tais direitos eram suspensos ou perdidos ${ }^{131}$.

I. Os que no Brazil tiverem nascido, quer sejam ingenuos, ou libertos, ainda que o pai seja estrangeiro, uma vez que este não resida por serviço de sua Nação. II. Os filhos de pai Brazileiro, e Os illegitimos de mãi Brazileira, nascidos em paiz estrangeiro, que vierem estabelecer domicilio no Imperio. III. Os filhos de pai Brazileiro, que estivesse em paiz estrangeiro em sorviço do Imperio, embora elles não venham estabelecer domicilio no Brazil. IV. Todos os nascidos em Portugal, e suas Possessões, que sendo já residentes no Brazil na época, em que se proclamou a Independencia nas Provincias, onde habitavam, adheriram á esta expressa, ou tacitamente pela continuação da sua residencia. V. Os estrangeiros naturalisados, qualquer que seja a sua Religião. A Lei determinará as qualidades precisas, para se obter Carta de naturalisação.

Art. 7. Perde os Direitos de Cidadão Brazileiro

I. O que se nataralisar em paiz estrangeiro. II. O que sem licença do Imperador aceitar Emprego, Pensão, ou Condecoração de qualquer Governo Estrangeiro. III. O que for banido por Sentença.

${ }^{128}$ Pimenta Bueno, José Antônio, Direito Público Brasileiro e Análise da Constituição do Império, Brasília, Universidade de Brasília, 1978, p. 440. Em outro trecho o autor afirmou que a norma do artigo $6^{\circ}$ da Constituição Imperial de 1824 não teria nem mesmo caráter constitucional: “(...) entendemos que a disposição do artigo $6^{\circ}$ da Constituição não tem caráter constitucional, e sim de lei ordinária (...) As leis constitucionais ou políticas só têm por objeto e fim definir e estabelecer as atribuições e relações dos poderes políticos, assim como dos direitos dos cidadãos ativos nessa ordem; nada têm com as relações de mera nacionalidade, que necessariamente pressupõem a cargo da lei civil (...)" in PIMENTA BUENO, José Antônio, idem, p. 441.

${ }^{129}$ Art 69 - São cidadãos brasileiros: $1^{\circ}$ ) os nascidos no Brasil, ainda que de pai estrangeiro, não, residindo este a serviço de sua nação; $2^{\circ}$ ) os filhos de pai brasileiro e os ilegítimos de mãe brasileira, nascidos em país estrangeiro, se estabelecerem domicílio na República; $3^{\circ}$ ) os filhos de pai brasileiro, que estiver em outro país ao serviço da República, embora nela não venham domiciliar-se; $4^{\circ}$ ) os estrangeiros, que achando-se no Brasil aos 15 de novembro de 1889, não declararem, dentro em seis meses depois de entrar em vigor a Constituição, o ânimo de conservar a nacionalidade de origem; $5^{\circ}$ ) os estrangeiros que possuírem bens imóveis no Brasil e forem casados com brasileiros ou tiverem filhos brasileiros contanto que residam no Brasil, salvo se manifestarem a intenção de não mudar de nacionalidade; $6^{\circ}$ ) os estrangeiros por outro modo naturalizados.

${ }^{130}$ Art 70 - São eleitores os cidadãos maiores de 21 anos que se alistarem na forma da lei.

$\S 1^{\circ}$ - Não podem alistar-se eleitores para as eleições federais ou para as dos Estados: $1^{\circ}$ ) os mendigos; $2^{\circ}$ ) os analfabetos; $3^{\circ}$ ) as praças de pré, excetuados os alunos das escolas militares de ensino superior; $4^{\circ}$ ) os religiosos de ordens monásticas, companhias, congregações ou comunidades de qualquer denominação, sujeitas a voto de obediência, regra ou estatuto que importe a renúncia da liberdade Individual. 
Nas Constituição Federal de 1934, por sua vez, as referências à expressão cidadão são secundárias, ou seja, buscam identificar critérios para titularidade de cargos públicos ${ }^{132}$ (nesse sentido como sinônimo de nacional ou de mero indivíduo) ou para o exercício do direito de petição ${ }^{133}$ e da declaração de nulidade ou anulação dos atos lesivos do patrimônio da União, dos Estados ou dos Municípios ${ }^{134}$.

A Carta outorgada de 1937, na epígrafe Da Nacionalidade e Da Cidadania, entre os artigos 115 e $121^{135}$, regula a aquisição e a perda da nacionalidade brasileira e, em seguida, a titularidade, a suspensão e a perda dos direitos políticos. Isso leva a crer que tenha identificado o direito à participação política com a noção de cidadania. A mesma estrutura esteve presente no Capítulo I (Da Nacionalidade e Da Cidadania) do Título IV (Da Declaração de Direitos) da Constituição Federal de $1946^{136}$. Em ambos os textos,

$\S 2^{\circ}$ - São inelegíveis os cidadãos não alistáveis.

${ }_{131}$ Art 71 - Os direitos de cidadão brasileiro só se suspendem ou perdem nos casos aqui particularizados.

$\S 1^{\circ}$ - Suspendem-se: a) por incapacidade física ou moral; b) por condenação criminal, enquanto durarem os seus efeitos.

$\S 2^{\circ}$ - Perdem-se: a) por naturalização em pais estrangeiro; b) por aceitação de emprego ou pensão de Governo estrangeiro, sem licença do Poder Executivo federal.

$\S 3^{\circ}$ - Uma lei federal determinará as condições de reaquisição dos direitos de cidadão brasileiro.

${ }_{132}^{132}$ Artigo $3^{\circ}, \S 2^{\circ}$; artigo 80, parágrafo único; artigo 82, § $2^{\circ}, c$; artigo $95, \S 1^{\circ}$.

${ }^{133}$ Artigo $113, \mathrm{n}^{\circ} 35$.

${ }^{134}$ Artigo $113, \mathrm{n}^{\circ} 38$.

135 DA NACIONALIDADE E DA CIDADANIA Art 115 - São brasileiros: a) os nascidos no Brasil, ainda que de pai estrangeiro, não residindo este a serviço do governo do seu país; b) os filhos de brasileiro ou brasileira, nascidos em país estrangeiro, estando os pais a serviço do Brasil e, fora deste caso, se, atingida a maioridade, optarem pela nacionalidade brasileira; c) os que adquiriram a nacionalidade brasileira nos termos do art. $69, \mathrm{n}^{\mathrm{o}} \mathrm{s} 4$ e 5 , da Constituição de 24 de fevereiro de 1891; d) os estrangeiros por outro modo naturalizados.

Art 116 - Perde a nacionalidade o brasileiro: a) que, por naturalização voluntária, adquirir outra nacionalidade; b) que, sem licença do Presidente da República, aceitar de governo estrangeiro comissão ou emprego remunerado; c) que, mediante processo adequado tiver revogada a sua naturalização por exercer atividade política ou social nociva ao interesse nacional.

Art 117 - São eleitores os brasileiros de um e de outro sexo, maiores de dezoito anos, que se alistarem na forma da lei.

Parágrafo único - Não podem alistar-se eleitores: a) os analfabetos; b) os militares em serviço ativo; c) os mendigos; d) os que estiverem privados, temporária ou definitivamente, dos direitos políticos.

Art 118 - Suspendem-se os direitos políticos: a) por incapacidade civil; b) por condenação criminal, enquanto durarem os seus efeitos.

Art 119 - Perdem-se os direitos políticos: a) nos casos do art. 116; b) pela recusa, motivada por convicção religiosa, filosófica ou política, de encargo, serviço ou obrigação imposta por lei aos brasileiros; c) pela aceitação de título nobiliárquico ou condecoração estrangeira, quando esta importe restrição de direitos assegurados nesta Constituição ou incompatibilidade com deveres impostos por lei.

Art 120 - A lei estabelecerá as condições de reaquisição dos direitos políticos.

Art 121 - São inelegíveis os inalistáveis, salvo os oficiais em serviço ativo das forças armadas, os quais, embora inalistáveis, são elegíveis.

${ }^{136}$ TíTULO IV Da Declaração de Direitos CAPíTUlO I

Da Nacionalidade e da Cidadania - Art 129 - São brasileiros: I - os nascidos no Brasil, ainda que de pais estrangeiros, não residindo estes a serviço do seu país; II - os filhos de brasileiro ou brasileira, nascidos no estrangeiro, se os pais estiverem a serviço do Brasil, ou, não o estando, se vierem residir no País. Neste caso, atingida a maioridade, deverão, para conservar a nacionalidade brasileira, optar por ela, dentro em quatro anos; III - os que adquiriram a nacionalidade brasileira nos termos do art. $69, \mathrm{n}{ }^{\text {os }} \mathrm{IV}$ e V, da Constituição de 
portanto, ainda que tenha sido feita a distinção entre nacionalidade e cidadania, esta

24 de fevereiro de 1891; IV - os naturalizados pela forma que a lei estabelecer, exigidas aos portugueses apenas residência no País por um ano ininterrupto, idoneidade moral e sanidade física.

Art 130 - Perde a nacionalidade o brasileiro: I - que, por naturalização voluntária, adquirir outra nacionalidade; II - que, sem licença do Presidente da República, aceitar de governo estrangeiro comissão, emprego ou pensão; III - que, por sentença judiciária, em processo que a lei estabelecer, tiver cancelada a sua naturalização, por exercer atividade nociva ao interesse nacional.

Art 131 - São eleitores os brasileiros maiores de dezoito anos que se alistarem na forma da lei.

Art 132 - Não podem alistar-se eleitores: I - os analfabetos; II - os que não saibam exprimir-se na língua nacional; III - os que estejam privados, temporária ou definitivamente, dos direitos políticos.

Parágrafo único - Também não podem alistar-se eleitores as praças de pré, salvo os aspirantes a oficial, os suboficiais, os subtenentes, os sargentos e os alunos das escolas militares de ensino superior.

Art 133 - O alistamento e o voto são obrigatórios para os brasileiros de ambos os sexos, salvo as exceções previstas em lei.

Art 134 - O sufrágio é universal e, direto; o voto é secreto; e fica assegurada a representação proporcional dos Partidos Políticos nacionais, na forma que a lei estabelecer.

Art 135 - Só se suspendem ou perdem es direitos políticos nos casos deste artigo.

$\S 1^{\circ}$ - Suspendem-se: I - por incapacidade civil absoluta; II - por condenação criminal, enquanto durarem os seus efeitos.

$\S 2^{\circ}$ - Perdem-se: I - nos casos estabelecidos no art. 130; II - pela recusa prevista no art. $141, \S 8^{\text {o }}$; III - pela aceitação de título nobiliário ou condecoração estrangeira que importe restrição de direito ou dever perante o Estado.

Art 136 - A perda dos direitos políticos acarreta simultaneamente a do cargo ou função pública.

Art 137 - A lei estabelecerá as condições de requisição dos direitos políticos e da nacionalidade.

Art 138 - São inelegíveis os inalistáveis e os mencionados no parágrafo único do art. 132.

Art 139 - São também inelegíveis: I - para Presidente e Vice-Presidente da República: a) o Presidente que tenha exercido o cargo, por qualquer tempo, no período imediatamente anterior, e bem assim o VicePresidente que lhe tenha sucedido ou quem, dentro dos seis meses anteriores ao pleito, o haja substituído; b) até seis meses depois de afastados definitivamente das funções, os Governadores, os interventores federais, nomeados de acordo com o art. 12, os Ministros de Estado e o Prefeito do Distrito Federal; c) até três meses depois de cessadas definitivamente as funções, os Ministros do Supremo Tribunal Federal e o Procurador Geral da República, os Chefes de Estado-Maior, os Juízes, o Procurador-Geral e os Procuradores Regionais da Justiça Eleitoral, os Secretários de Estado e os Chefes de Polícia; II - para Governador: a) em cada Estado, o Governador que haja exercido o cargo por qualquer tempo no período imediatamente anterior ou quem lhe haja sucedido, ou, dentro dos seis meses anteriores ao pleito, o tenha substituído; e o interventor federal, nomeado na forma do art. 12, que tenha exercido as funções, por qualquer tempo, no período governamental imediatamente anterior; b) até um ano depois de afastados definitivamente das funções, o Presidente, o Vice-Presidente da República e os substitutos que hajam assumido a Presidência; c) em cada Estado, até três meses depois de cessadas definitivamente as funções, os Secretários de Estado, os Comandantes das Regiões Militares, os Chefes e os Comandantes de Polícia, os Magistrados federais e estaduais e o Chefe do Ministério Público; d) até três meses depois de cessadas definitivamente as funções, os que forem inelegíveis para Presidente da República, salvo os mencionados nas letras $a$ e $b$ deste número; III - para Prefeito, o que houver exercido o cargo por qualquer tempo, no período imediatamente anterior, e bem assim o que lhe tenha sucedido, ou, dentro dos seis meses anteriores ao pleito, o haja substituído; e, igualmente, pelo mesmo prazo, as autoridades policiais com jurisdição no Município; IV - para a Câmara dos Deputados e o Senado Federal, as autoridades mencionadas em os $\mathrm{n}^{\mathbf{o}}$ I e II, nas mesmas condições em ambos estabelecidas, se em exercício nos três meses anteriores ao pleito; V - para as Assembléias Legislativas, os Governadores, Secretários de Estado e Chefes de Polícia, até dois meses depois de cessadas definitivamente as funções.

Parágrafo único - Os preceitos deste artigo aplicam-se, aos titulares, assim efetivos como interinos, dos cargos mencionados.

Art 140 - São ainda inelegíveis, nas mesmas condições do artigo anterior, o cônjuge e os parentes, consangüíneos ou afins, até o segundo grau: I - do Presidente e do Vice-Presidente da República ou do substituto que assumir a presidência: a) para Presidente e Vice-Presidente; b) para Governador; c) para Deputado ou Senador, salvo se já tiverem exercido o mandato ou forem eleitos simultaneamente com o Presidente e o Vice-Presidente da República; II - do Governador ou interventor federal, nomeado de acordo com o art. 12, em cada Estado: a) para Governador; b) para Deputado ou Senador, salvo se já tiverem exercido o mandato ou forem eleitos simultaneamente com o Governador; III - do Prefeito, para o mesmo cargo. 
assumiu significa restrito, correspondendo ao rol de direitos políticos. Para CAVAlCANTI $^{137}$, comentando o artigo 129 da Constituição Federal de 1946, a concepção restritiva de cidadania era evidente, tanto no título como no desenvolvimento do capítulo, que detalhava os direitos e deveres dos cidadãos (de caráter político, conforme se depreende da leitura dos dispositivos). Para o autor, cidadania era função da nacionalidade, da qual participava apenas o nacional que preenchesse os requisitos mínimos previstos.

Também na Constituição de 1967 e na Emenda Constitucional n ${ }^{\circ}$ 1, de 17 de outubro de 1969, a noção de cidadania parece apresentar-se com caráter restritivo. Em ambas, o artigo $8^{\circ}$, inciso VII, alínea $o$, afirma ser competência da União legislar sobre nacionalidade, cidadania e naturalização. Na alínea $c$ do inciso II do artigo 144 da Constituição de 1967 (equivalente ao artigo 149 da Emenda $n^{\circ}$ 1/1969), ao regular os direitos políticos, determina-se que eles serão perdidos pela aceitação de condecoração ou título nobiliário estrangeiros que importem restrição de direito de cidadania ou dever para com o Estado brasileiro. Novamente o tema aparece essencialmente vinculado aos direitos políticos. PONTES DE MIRANDA alertou, todavia, ao comentar a Constituição de 1967 emendada, que era costume na terminologia tradicional fazer sinônimos os significados de cidadão e nacional ${ }^{138}$.

Naturalmente, a tradição constitucional e doutrinária influenciou autores pátrios que, após a promulgação da Constituição Federal de 1988, conceberam a noção de cidadania, ínsita no inciso II do artigo $1^{\circ}$ da Constituição Federal de 1988 como fundamento da República, ainda estritamente vinculada à titularidade de direitos de participação política.

Nesse sentido afirma BASTOS: "[a] cidadania, também fundamento de nosso Estado, é um conceito que deflui do próprio princípio do Estado Democrático de Direito, podendo-se, desta forma, dizer que o legislador constituinte foi pleonástico ao instituí-lo. No entanto, ressaltar a importância da cidadania nunca é demais, pois o exercício desta prerrogativa é fundamental. Sem ela, sem a participação política do indivíduo nos negócios

\footnotetext{
137 Afirmou o autor: "cidadania é função da nacionalidade. Sòmente o nacional, e que haja completado o quadro das exigências legais pode exercer esses direitos" in CAVAlCANTI, Themístocles Brandão, $A$ Constituição Federal Comentada, v. III, Rio de Janeiro, José Konfino, 1949, p. 6.

${ }^{138} \mathrm{Na}$ palavras do autor: "[t]em-se procurado substituir cidadãos, citoyen de l'État, Citizen, a nacional, national, propondo-se que à última expressão se dê o significado de cidadãos e estrangeiros residentes no Estado. Mas seria ir contra a terminologia tradicional, que faz sinônimos cidadão e nacional (...)" in PONTES DE MiRandA, Francisco Cavalcanti, Comentários à Constituição de 1967: com a emenda n. 1, de 1969, Tomo IV, São Paulo, Revista dos Tribunais, 1970, p. 349.
} 
do Estado e mesmo em outras áreas do interesse público, não há que se falar em democracia"139 (não sublinhado no original).

Assim também a lição de CRETELla JÚNIOR, ao comentar o mesmo inciso II do artigo $1^{\circ}$ da Constituição Federal de 1988: “[s]e nacionalidade é a sujeição por nascimento ou adoção, do indivíduo ao Estado, para o gozo e exercício dos direitos políticos, cidadania é a habilitação do nacional para o exercício desses mesmos direitos, cumpridos os requisitos legais"140. É, ademais, a posição de FERREIRA FILHO, para quem "[e]nfatizando cidadania, a nova Constituição brasileira quer apontar a indispensabilidade da participação popular na tomada das decisões políticas. O povo brasileiro deve ser composto de cidadãos, participantes ativos do exercício do poder democrático, não de súditos de qualquer poder, mesmo democrático" ${ }^{141}$.

Acrescente-se a esses autores, ainda, MORAES, que afirma que a "cidadania representa um status do ser humano, apresentando-se, simultaneamente, como objeto e direito fundamental das pessoas, conforme será analisado nos comentários ao artigo 14"142. Ao remeter ao artigo 14 da Constituição, que regula os direitos políticos, o autor parece fazer coro àqueles que adotam uma concepção restritiva de cidadania para os fins do inciso II do artigo $1^{\circ}$ da Constituição Federal de 1988.

Entretanto, a relevância de ser fundamento da República Federativa do Brasil parece não permitir que cidadania, com essa qualificação, continue a ser concebida restritivamente. Mais acertado é o alerta de SILVA ${ }^{143}$ acerca da necessidade de se reelaborar o conceito da expressão cidadania, banalizada pela repetição esvaziada no discurso político, com o fito de lhe atribuir maior precisão e operativade jurídica. Segundo o autor é preciso identificar uma nova dimensão da cidadania, que decorre "da idéia de Constituição de Constituição dirigente, que não é apenas um repositório de programas vagos a serem cumpridos, mas constitui um sistema de previsão de direitos sociais, mais ou menos

\footnotetext{
${ }^{139}$ BAstos, Celso Ribeiro, Curso de Direito Constitucional, São Paulo, Saraiva, 2000, p. 158.

${ }^{140}$ Cretella Júnior, José, Comentários à Constituição Brasileira de 1988, v. I, Rio de Janeiro, Forense Universitária, 1992, p. 138.

141 FerreIRA FILHO, Manoel Gonçalves, Comentários à Constituição brasileira de 1988, v. 1, São Paulo, Saraiva, 1990, p. 19.

${ }^{142}$ MORAES, Alexandre de, Constituição do Brasil interpretada e legislação constitucional, São Paulo, Atlas, 2002, p. 128.

${ }^{143}$ Nas palavras do autor: "[é] um signo de nosso tempo que a cidadania se tenha convertido em um conceito de moda em todos os setores da política. Isso nos põe diante da necessidade de reelaborar o conceito de 'cidadania', a fim de lhe dar sentido preciso e operativo em favor da população mais carente da sociedade e de modo a retirá-lo da pura ótica da retórica política, que, por ser formal, tende a esvaziar o conteúdo ético valorativo dos conceitos, pelo desgaste de sua repetição descomprometida" in SILVA, José Afonso da, Comentário Contextual à Constituição, São Paulo, Malheiros, 2009, p. 35.
} 
eficazes, em torno dos quais se vem construindo a nova idéia de cidadania" ${ }^{\text {"144 }}$. Essa cidadania, cujo fundamento para o autor é a consciência de pertinência à sociedade estatal, "requer providências estatais no sentido da satisfação de todos os direitos fundamentais em igualdade de condições" ${ }^{145}$.

Entende-se, assim, que a cidadania como fundamento do Estado, como prescreve o artigo $1^{\circ}$, inciso II da Constituição Federal de 1988, não poderia se circunscrever tão somente ao rol de direitos políticos previstos no artigo 14 do mesmo texto constitucional. Comentando o aludido inciso II, assim ensina SILVA: "[a] cidadania está aqui num sentido mais amplo do que o de titular de direitos políticos. Qualifica os participantes da vida do Estado, o reconhecimento do indivíduo como pessoa integrada na sociedade estatal (art. $5^{\circ}$, LXXVII). Significa aí, também, que o funcionamento do Estado estará submetido à vontade popular. E aí o tema conexiona-se com o conceito de soberania popular (parágrafo único do art. $1^{\circ}$ ), com os direitos políticos (art. 14) e com o conceito de dignidade da pessoa humana (art. $1^{\circ}$, III), com os objetivos da educação (art. 205), como base e meta essencial do regime democrático" ${ }^{146}$.

Concepção da mesma forma abrangente de cidadania é adotada por ARAUJO e NUNES JÚNIOR, para quem a expressão cidadania do dispositivo sob análise "indicada como fundamento da República, parece não se resumir à posse de direitos políticos, mas, em acepção diversa, parece galgar significado mais abrangente, nucleado na idéia, expressa por Hannah Arendt, do direito a ter direitos" ${ }^{\prime 147}$. Embora o conceito dos autores mantenha cidadania ligada à titularidade de direitos fundamentais, do que teria evoluído para identificar uma exigência de exercício desses direitos, ele é expressão de uma forma bem mais abrangente de concebê-la.

Essa também é a avaliação que TORRES faz do inciso II do artigo $1^{\circ}$ da Constituição Federal de 1988. Leciona que cidadania deve ser compreendida "como o pertencer à comunidade que assegura ao homem a sua constelação de direitos e o seu quadro de deveres (...). A cidadania já não está ligada à cidade nem ao Estado Nacional, pois ser

\footnotetext{
${ }^{144}$ Silva, José Afonso da, Comentário... cit., p. 35.

${ }^{145}$ SILVA, José Afonso da, Comentário... cit., p. 35.

${ }^{146}$ SILVA, José Afonso da, Curso de Direito Constitucional Positivo, Malheiros, São Paulo, 2008, p. 104.

147 Araujo, Luiz Alberto David e Nunes JúnIOR, Vidal Serrano, Curso de Direito Constitucional, São Paulo, Saraiva, 2007, p. 101.
} 
afirma também no espaço internacional e supranacional. Apenas as idéias de direitos humanos e de justiça podem constituí-la no sentido ontológico"148.

É esse significado amplo, mantendo a cidadania estatal como pressuposto não de titularidade, mas de exercício dos direitos humanos, que este trabalho analisa os dispositivos constitucionais relativos ao direito à educação e a legislação correlata. Com esse intuito, a cidadania estatal é tratada como um vínculo jurídico essencial para a fruição de direitos fundamentais que, a princípio, deve ensejar a seus portadores seu maior e melhor exercício.

Trata-se de um vínculo jurídico que reconhece o pertencimento do indivíduo à sociedade de que participa e do qual decorre a exigência de concretização de seu direito à educação. Essa exigência, do ponto de vista jurídico, materializa-se na estrutura normativa que se organiza para sua concretização, desde o texto constitucional (e, portanto, desde a própria declaração do direito na ordem interna) até a prática jurisprudencial sobre o tema.

148 TORRES, Ricardo Lobo, A cidadania multidimensional na era dos direitos, in TORRES, Ricardo Lobo (org.), Teoria dos Direitos Fundamentais, Rio de Janeiro, Renovar, 1999, p. 249. 


\title{
2. SOBRE A EDUCAÇÃO
}

\author{
Quando a lei fez dos homens todos iguais, a \\ única distinção que permaneceu dividindo-os em \\ diversas classes foi a sua educação ${ }^{149}$ (tradução livre).
}

Desde o Tractatus Logico-Philosophicus de Ludwig Wittgenstein, foi evidenciada a importância da linguagem para a construção do contexto social e para o próprio conhecimento humano. Seus limites são os mesmos do discurso e de sua utilização. A compreensão dos eventos materiais do mundo natural somente ocorre mediante a combinação de segmentos de linguagem, relacionando interpretações. É essa habilidade de construir e identificar significados, através das palavras, que distingue o conhecimento da mera sensação, e permite ao homem trabalhar o ambiente que o cerca ${ }^{150}$.

O sistema jurídico, como produto da cultura humana, é composto por uma estrutura comunicacional organizada na forma prescritiva, de modo que a preocupação com a utilização da linguagem hábil é ainda maior. Voltado a estimular e modificar o comportamento humano, através de comandos, advertências, sanções etc., é intensa a necessidade de existir clareza acerca dos enunciados lingüísticos utilizados nas prescrições do Direito. Conceitos amplos como educação, componente da expressão direito à educação, representam grande desafio.

\subsection{Significado da expressão educação como linguagem jurídica.}

\footnotetext{
${ }^{149}$ CONDORCET, Marquis de (Marie Jean Antoine Nicola de Caritat), Premier Mémoire sur L'instruction Publique (1791), Paris, Mille et une nuits, 2002, p. 10.

${ }^{150}$ Sobre a incapacidade humana de ter acesso aos acontecimentos materiais em si, mas somente à linguagem sobre eles ver Moussalem, Tárek Moysés, Conhecimento, linguagem e direito, in Jurídica - Revista do Curso de Direito da Universidade Federal do Espírito Santo, n. 2, Vitória, 2000, p. 79.
} 
No glossário do Relatório de Monitoramento Educação Para Todos da UNESCO ${ }^{151}$ (2008) educação geral é definida como:

"Programas elaborados principalmente para levar aos estudantes uma compreensão mais profunda de uma disciplina ou de um grupo de disciplinas, visando principalmente, mas não necessariamente, prepará-los para a educação futura, seja no mesmo nível, seja em um nível mais elevado. Esses programas são tipicamente baseados na escola e podem ou não conter elementos profissionalizantes. A conclusão desses programas não garante aos estudantes uma qualificação de relevância no mercado de trabalho.” (tradução livre)

E educação básica é definida como:

“A gama completa de atividades educacionais que se realizam em diversos ambientes (formais, não-formais e informais) com o objetivo de satisfazer as necessidades básicas de aprendizagem.” (tradução livre)

Por sua vez, ainda no âmbito da UNESCO, o International Standard Classification of Education - ISCED ${ }^{152}$ (1997) define educação da seguinte forma:

“12. (...) [E]ducação, para o propósito do ISCED, inclui uma variedade de programas e tipos de educação que são designados no contexto nacional como educação regular, educação de adultos, educação formal e informal, educação inicial, educação continuada, educação à distância, educação aberta, educação para toda a vida, educação de meio período, sistemas duais, sistema de aprendizes, educação técnico-vocacional, treinamento, educação para portadores de necessidades especiais (...). 13. De modo que educação, para os fins do ISCED, exclui formas de aprendizagem que não sejam organizadas. Assim, enquanto toda educação envolve aprendizado, muitas formas de aprendizado não podem ser tomadas como educação. Por exemplo, aprendizagem incidental ou aleatória que ocorre como um subproduto de um outro evento, tal como algo que se cristaliza no curso de uma reunião, é excluído [do conceito de educação] porque não é organizado, i.e., não resulta de uma intervenção planejada com vistas a produzir aprendizado." (tradução livre)

Em ambas as definições, educação aparece como processo formativo intelectual de crianças (sobretudo), a ser conduzido, geralmente, pelas gerações mais velhas. Nessa perspectiva, ainda que excluídas do conceito de educação para o ISCED as formas não organizadas de aprendizagem, a idéia permanece, todavia, com grande amplitude. Essa constatação, evidentemente, leva ao seguinte questionamento: do ponto de vista da titularidade e da aplicação do direito à educação, especificamente no caso brasileiro, utiliza-se semelhante significado amplo de educação?

${ }^{151}$ UNESCO, Global Monitoring Report on Education for All, 2008, p. 391.

${ }^{152}$ UNESCO, International Standard Classification - ISCED, 1997, p. 10. 
O pesquisador pode socorrer-se, primeiramente, das convenções internacionais de direitos humanos. Em verdade, a própria Declaração Universal dos Direitos Humanos de 1948, a despeito de não ostentar efeito vinculante, acena, em seu preâmbulo, para um possível conteúdo de educação ao afirmar ser através dela que os povos e nações devem promover os direitos e liberdades ali declarados.

Mas é no Pacto Internacional sobre Direitos Econômicos, Sociais e Culturais de 1966 e na Convenção sobre os Direitos da Criança de 1989 que se encontram elementos de maior auxílio.

Assim, no artigo 13 do Pacto de 1966 estabelece-se:

\section{“Artigo 13}

1. Os Estados Signatários do presente Pacto reconhecem o direito de toda pessoa à educação. Concordam que a educação deve ser orientada para o pleno desenvolvimento da personalidade humana e do sentido de sua dignidade e deve fortalecer o respeito pelos direitos humanos e liberdades fundamentais. Concordam, ainda, que a educação deve capacitar a todas as pessoas para participar efetivamente numa sociedade livre, favorecer a compreensão a tolerância e a amizade entre todas as nações e entre todos os grupos raciais, étnicos ou religiosos, e promover as atividades das Nações Unidas em prol da manutenção da paz.”

E no artigo 29 da Convenção sobre Direitos da Criança encontra-se a seguinte disposição:

\section{"Artigo 29}

1. Os Estados Partes reconhecem que a educação da criança deverá estar orientada no sentido de:

a) desenvolver a personalidade, as aptidões e a capacidade mental e física da criança em todo o seu potencial;

b) imbuir na criança o respeito aos direitos humanos e às liberdades fundamentais, bem como aos princípios consagrados na Carta das Nações Unidas;

c) imbuir na criança o respeito aos seus pais, à sua própria identidade cultural, ao seu idioma e seus valores, aos valores nacionais do país em que reside, aos do eventual país de origem, e aos das civilizações diferentes da sua;

d) preparar a criança para assumir uma vida responsável numa sociedade livre, com espírito de compreensão, paz, tolerância, igualdade de sexos e amizade entre todos os povos, grupos étnicos, nacionais e religiosos e pessoas de origem indígena;

e) imbuir na criança o respeito ao meio ambiente." 
Como visto, as duas disposições utilizam-se da expressão a educação deve ser orientada. Isso implica que um eventual significado extraído delas teria de ser reconhecido como um conceito teleológico, definindo educação pelos seus fins. Solução semelhante, aliás, será atingida a partir do artigo 205 da Constituição Federal de 1988:

Artigo 205. A educação, direito de todos e dever do Estado e da família, será promovida e incentivada com a colaboração da sociedade, visando ao pleno desenvolvimento da pessoa, seu preparo para o exercício da cidadania e sua qualificação para o trabalho.

Admitindo-se a educação, genericamente, como processo formativo ${ }^{153}$, é de grande importância conhecer quais os resultados que o cidadão (aquele que deve exercer os seus direitos fundamentais) tem direito a ver alcançados. Ademais, estabelecidas finalidades tais como as presentes nos dispositivos arrolados, permite-se conceber, como faz TOMASEVSKI ${ }^{154}$, que dentro de uma perspectiva de direitos humanos a educação constitui um fim em si mesma, uma vez que voltada à satisfação humana, ou seja, ao desenvolvimento da própria pessoa (de sua personalidade, capacidade mental, consciência humanitária e ambiental etc.).

Assim, ficam afastadas concepções econômico-utilitárias, tal como a de MINGAT ${ }^{155}$, que define a educação como um processo de produção de capital humano, cujo propósito seria prover pessoas qualificadas, por período prolongado, em quantidade e qualidade determinadas pela demanda da economia. Conforme salienta TOMASEVSKI ${ }^{156}$, a visão de capital humano é incompatível com a noção de sujeito de direito na perspectiva dos direitos humanos e seu efeito pode ser nocivo. Basta imaginar seu resultado quando aplicada à educação de pessoas portadoras de deficiências: uma educação geralmente de alto custo, com evidente baixo retorno econômico.

Evidentemente, o desenvolvimento de capacidades voltadas ao aumento da produtividade econômica do indivíduo insere-se dentre os resultados esperados da educação. Porém, constitui apenas um de seus propósitos. Em relação à educação, deve-se

\footnotetext{
${ }^{153}$ Ver, exemplificativamente, MARTINES, que afirma "[A] educação só pode ser entendida como processo que tem por escopo preparar as novas gerações para substituírem as adultas que se retiram das funções ativas da sociedade, inclusive pela ação do tempo, permitindo a conservação, o aprimoramento e a transmissão de toda a cultura, esse conjunto de valores e formas comportamentais adequados à vida social." in MARTINES JÚNIOR, Eduardo, Educação, Cidadania... cit., p. 26.

${ }_{154}$ TOMASEVSKI, Katarina, Right To Education Primers: removing obstacles in the way of the right to education, Gothenburg, Novum Grafiska AB, 2001.

${ }^{155}$ MINGAT, T., The strategy used by high-performing Asian economies in education: some lessons for developing countries, in World Development, vol. 26, n. 4, 1998, pp. 697 e 700, apud TOMASEVSKI, Katarina, Right To... cit., p. 37.

${ }^{156}$ TOMASEVSKI, Katarina, Right To... cit., p. 37.
} 
sempre cuidar para não se adotarem soluções reducionistas que possam dificultar sua compreensão como meio de desenvolvimento integral da personalidade humana, não apenas de suas partes.

Entretanto, a despeito de sua importância, o elemento teleológico do conceito não esclarece em que consiste o mecanismo de alcance desses resultados. Esta preocupação é imprescindível à definição de educação enquanto segmento lingüístico normativo, componente da expressão direito à educação. Se é importante saber que existe um direito a que a educação permita ao indivíduo atingir determinados resultados, é da mesma forma essencial, do ponto de vista jurídico-pragmático, ter clareza acerca do formato em que isso deve ocorrer, vale dizer, conhecer qual é o processo formativo a que se tem direito. Nesse sentido questiona RANIERI: "trata-se da educação formal ou da informal? Da pública ou da privada? Encampa todas as atividades inerentes à educação, ou só algumas?"157. São questionamentos de grande relevância, sobretudo se for considerado que a exigibilidade jurídica somente pode recair sobre o instrumento, mas não sobre os resultados em si, uma vez que a aprendizagem, como se sabe, demanda a atuação paralela do interlocutor no sentido de se permitir aprender ${ }^{158}$.

Ao que parece, apesar de já profusa na seara da atividade educacional, a jurisprudência brasileira ainda não fornece uma delimitação quanto a essa questão específica. Na doutrina, por sua vez, educação vem geralmente conceituada como direito fundamental, de natureza social, cuja finalidade é permitir o pleno desenvolvimento da pessoa, seu preparo para o exercício da cidadania e sua qualificação ao trabalho, a ser exigido em face do Estado, da família e da sociedade ${ }^{159}$. Tal conceito fornece a natureza, a titularidade e o(s) sujeito(s) passivo(s), mas não propriamente o objeto.

Ademais, a própria pluralidade de dimensões da educação traz grande complexidade: em cada uma delas, educação, como enunciado normativo, pode assumir uma acepção peculiar. Quanto às relações entre crianças e seus pais ou representantes

\footnotetext{
${ }^{157}$ RANIERI, Nina Beatriz Stocco, O Estado Democrático de Direito e o Sentido da Exigência de Preparo da Pessoa para o Exercício da Cidadania, pela Via da Educação, Tese (Livre-Docência) - Faculdade de Direito da Universidade de São Paulo, São Paulo, 2009, p.281.

${ }^{158}$ Nesse sentido ver CRETELLA JÚNIOR, José, Comentários à constituição brasileira de 1988, Rio de Janeiro, 1993, v. 3, p. 4406.

${ }^{159}$ Nesse sentido, com alguma variação sobre a maior ou menor prevalência da exigibilidade face ao Estado do direito à educação, ver RANIERI, Nina Beatriz Stocco, O Estado Democrático... cit., SiLVA, José Afonso da, Curso de Direito Constitucional Positivo, São Paulo, Malheiros, 2008, p. 312-313, GARCIA, Emerson, $O$ Direito à Educação e suas Perspectivas de Efetividade, in GARCIA, Emerson (coord.), A Efetividade dos Direito Sociais, Rio de Janeiro, Lúmen Júris, 2004, p. 149 a 198, MARTINES JúNIOR, Eduardo, Educação, Cidadania... cit., entre outros.
} 
legais, integra o dever de criação, assistência e educação, matéria relativa ao direito de infância, que encontra guarida no artigo 229 da Constituição Federal. Pode indicar a aprendizagem através do trabalho para o menor entre 14 e 16 anos de idade, mencionada no artigo $7^{\circ}$, inciso XXXIII da Constituição Federal de 1988. Pode referir-se ao direito dos pais de escolher a educação de seus filhos. Pode estar relacionada ao melhor formato de educação para uma formação em direitos humanos. Pode referir-se, ainda, ao direito do indivíduo à preservação cultural de seu contexto social, através de aprendizados de tradição, religião etc. Estes são apenas alguns exemplos.

Portanto, a título de delimitação do tema, resta evidente que a pesquisa demanda a determinação de uma premissa essencial: o que constitui o signo educação no enunciado direito à educação na análise específica deste? Neste trabalho, para fins de compreensão do direito à educação, toma-se a educação enquanto processo formativo organizado institucionalmente, ou seja, aquela que, oferecida em estabelecimentos oficiais ou não oficiais, esteja sujeita aos atos autorizativos do Estado bem como à sua fiscalização quanto à qualidade, e que forneça ao indivíduo a certificação validada pelo próprio sistema. Mas, agora a título de esclarecimento, deve-se repetir: entende-se que esta é apenas uma forma possível de encarar o direito a educação, dentre várias. É a forma eleita nesta Dissertação. Essa via também é adotada por SIFUENTES, que trata o direito à educação "como a atividade que se desenvolve, preferencialmente, na escola" ${ }^{\text {} 160}$.

RANIERI $^{161}$ leciona acerca da diferença existente entre educação e ensino no direito brasileiro. Em síntese, afirma ser possível distinguir educação genérica em ensino formal e ensino informal. Parece possível acrescentar que seria uma distinção segundo um critério de presença ou ausência de institucionalidade no processo formativo. Assim, ensino formal é o processo educativo ministrado por instituições escolares, ou seja, diretamente pelo Estado, ou sob sua autorização e controle de qualidade. Já o aprendizado realizado no âmbito da família, do trabalho e da sociedade de modo geral, fora da escola, consistiria ensino informal.

\footnotetext{
160 SIFUENTES, Mônica, Direito Fundamental à Educação. A Aplicabilidade dos Dispositivos Constitucionais, Porto Alegre, Núria Fabris, 2009, p. 40.

${ }^{161}$ RANIERI, Nina Beatriz Stocco, O Estado Democrático... cit., p.284.
} 
É, portanto, do ensino formal ${ }^{162}$, conforme a lição de RANIERI, que trata esta Dissertação. Neste aspecto é que o direito à educação é analisado: direito à educação institucionalmente oferecida.

A justificativa desta eleição é, essencialmente, o fato de que é sob esse significado que a Constituição Federal de 1988, nos artigos 205 e seguintes, trata com extensa pormenorização do direito à educação, no que há, segundo manifestação do Supremo Tribunal Federal, delineamento constitucional das políticas públicas de educação, inclusive com previsão de prioridade orçamentária ${ }^{163}$.

Diante disso, vislumbra-se o estabelecimento dos fins e da forma do direito à educação. Note-se, todavia, que essa determinação não resolve o problema, uma vez que ainda falta a clareza quanto ao conteúdo juridicamente exigível do direito à educação. Esta é questão de ainda maior complexidade, que se procurará aprofundar nos tópicos seguintes. Antes, porém, com o mesmo fim de esclarecimento de significados, são necessárias algumas elucidações a respeito da estrutura do direito à educação, conforme compreendido neste trabalho.

\subsection{Dimensões do direito à educação.}

O desenvolvimento dos direitos fundamentais ${ }^{164}$ está intimamente ligado ao caminho de construção da cidadania apresentado anteriormente. É possível afirmar que ambos os processos desenrolam a mesma história, que também é a história da formação do Estado moderno. Assim ensina BOBBIO ao afirmar que a afirmação dos direitos fundamentais derivou de uma característica da formação do Estado moderno que foi a inversão de perspectiva na relação Estado/cidadão ou soberano/súditos. Em suas palavras, relação que passa a ser "encarada, cada vez mais, do ponto de vista dos direitos dos

\footnotetext{
${ }^{162}$ Sobre a denominação, cumpre notar que ensino formal pode também ser tratado por educação escolar ou meramente por ensino, conforme o que estabelece o $\S 1^{\circ}$ do artigo $1^{\circ}$ da Lei $n^{\circ}$ 9.394/96 (Lei de Diretrizes e Bases da Educação Nacional): $\$ 1^{\circ}$. Esta Lei disciplina a educação escolar, que se desenvolve, predominantemente, por meio do ensino, em instituições próprias.

${ }_{163}$ Cf. Brasil, Supremo Tribunal Federal, Suspensão de Tutela Antecipada n ${ }^{\circ} 318$, Relator Ministro Presidente Gilmar Mendes, Julgamento em 20.04.2009.

${ }^{164}$ É comum na doutrina a crítica ao uso indiscriminado de terminologias como direitos naturais, direitos humanos e direitos fundamentais enquanto sinônimas. Neste trabalho, dada a preocupação com a positivação no ordenamento vigente, adota-se a forma direitos fundamentais. Para explicação acerca do diferente conteúdo das diversas preocupação ver, entre outros, BONAVIDES, Paulo, Curso de Direito Constitucional, São Paulo, Malheiros, 2006, pp. 560 a 562, e Silva, José Afonso da, Curso de Direito Constitucional Positivo, São Paulo, Malheiros, 2008, pp. 175 a 179.
} 
cidadãos não mais súditos, e não mais do ponto de vista dos direitos do soberano, em correspondência com a visão individualista da sociedade, segundo a qual, para compreender a sociedade, é preciso partir de baixo, ou seja, dos indivíduos que a compõem, em oposição à concepção orgânica tradicional, segundo a qual a sociedade como um todo vem antes dos indivíduos"165.

Essa inversão foi socialmente produzida. Adveio num primeiro momento, como advertiu BоввіO, das guerras de religião e do combate às instituições arbitrárias e absolutistas, como esforço a fazer reconhecer direitos e liberdades primários, como a liberdade religiosa e as liberdades civis. Sequencialmente, direitos políticos e sociais desenvolveram-se a partir das reivindicações de trabalhadores assalariados e camadas pobres em geral, crescentemente $\operatorname{organizados}^{166}$. Trata-se da substituição da lógica medieval de prerrogativas atribuídas para a lógica de direitos conquistados, inerente ao Estado moderno de que falam MARSHALL e TURNER, conforme visto acima.

Diante dessa conclusão, é forçoso admitir a legitimação histórico-social dos direitos fundamentais. Portanto, em síntese, pode-se afirmar que estes constituem direitos requeridos e construídos socialmente, decorrentes da compreensão de dignidade humana em determinado momento histórico, e que, nesses termos, foram reconhecidos no âmbito do direito positivo. Essa é a lição de SILVA ${ }^{167}$.

É corrente na doutrina falar-se em três gerações ou dimensões dos direitos fundamentais. Não é o caso de apresentar aqui extensas explicações sobre o tema, mesmo porque, novamente, o seu desenvolvimento é semelhante ao do tema da cidadania, visto anteriormente.

Apenas relembre-se que os ditos direitos fundamentais de primeira dimensão compreendem aquelas liberdades individuais limitadoras do poder estatal de intervenção, típicas das primeiras declarações de direitos burguesas. Como se sabe, são liberdades que

\footnotetext{
${ }^{165}$ BobBIO, Norberto, A Era dos Direitos, Rio de Janeiro, Elsevier, 2004, p. 24.

${ }^{166}$ Nesse sentido afirma BOBBIO: "a liberdade religiosa é um efeito das guerras de religião; as liberdades civis, da luta dos parlamentos contra os soberanos absolutos; a liberdade política e as liberdades sociais, do nascimento, crescimento e amadurecimento do movimento dos trabalhadores assalariados, dos camponeses com pouca ou nenhuma terra, dos pobres que exigem dos poderes públicos não só o reconhecimento da liberdade pessoal e das liberdades negativas, mas também a proteção do trabalho contra o desemprego, os primeiros rudimentos de instrução contra o analfabetismo, depois a assistência para a invalidez e a velhice, todas elas carecimentos que os ricos proprietários podiam satisfazer por si mesmos" in BOBBIO, Norberto, $A$ Era dos Direitos, Rio de Janeiro, Elsevier, 2004, p. 25.

${ }^{167}$ Silva, José Afonso da, Curso de Direito Constitucional Positivo, São Paulo, Malheiros, 2008, p. 178. Em sentido semelhante, entre outros, ver BobBio, Norberto, A Era dos Direitos, Rio de Janeiro, Elsevier, 2004, e LAFER, Celso, A Reconstrução dos Direitos Humanos. Um diálogo com o pensamento de Hannah Arendt, São Paulo, Companhia das Letras, 2006.
} 
apenas excepcionalmente podem ser limitadas, através de determinação legal e desde que respeitados formal e materialmente os limites constitucionais. Em uma frase, direitos de resistência e oposição perante o Estado ${ }^{168}$.

Os direitos de segunda dimensão (direitos sociais, econômicos e culturais) possuem estrutura inversa em relação aos direitos de primeira. Enquanto estes demandam abstenção do Estado, aqueles se caracterizam por expressar direitos a ações estatais positivas ${ }^{169}$. Assumem a forma de imposições constitucionais ao poder público no sentido de realizar determinadas medidas em busca da promoção do bem estar do povo e de sua segurança econômica e social ${ }^{170}$. São direitos que exigem a organização de políticas públicas voltadas a permitir seu exercício e que, por essa razão, realizam-se eminentemente através dos serviços públicos ${ }^{171}$. Seu fundamento é a igualdade substancial ou real, de modo a permitir que todos os indivíduos efetivamente usufruam das liberdades referentes à primeira dimensão. É o que CANOTILHO denomina liberdade igual ${ }^{172}$.

Finalmente, direitos de terceira dimensão consistem naqueles cujos titulares não podem ser individualizados, mas compreendem grupos humanos, como a família, os nacionais de determinado país, ou até mesmo o conjunto da humanidade ${ }^{173}$, a exemplo dos ditos direitos de espécie (direito à biossegurança, direito à não manipulação genética etc.) ou ainda do direito a um meio ambiente saudável. Nesse contexto de titularidade coletiva insere-se o direito ao desenvolvimento, tema intimamente ligado ao direito à educação. Trata-se, em verdade, de direito relativo a Estados, mas também a indivíduos, sendo que em relação a estes o direito ao desenvolvimento expressa uma pretensão ao trabalho, à saúde e à alimentação adequada ${ }^{174}$.

Adota-se o vocábulo dimensão de direitos fundamentais por facilitação no discurso. Mas abstém-se de comentar as críticas ao uso da expressão gerações de direitos fundamentais por se entendê-las despropositadas, uma vez que não é razoável acreditar que

\footnotetext{
${ }^{168}$ Cf. Bonavides, Paulo, Curso de... cit., p. 564.

169 Cf. AleXY, Robert, Teoria de los Derechos Fundamentales, Madrid, Centro de Estúdios Políticos y Constitucionalies, 2002, p. 419.

170 Cf. Canotilho, José Joaquim Gomes, Direito Constitucional e Teoria da Constituição, Coimbra, Almedina, 2000, p. 465.

${ }^{171}$ Cf. WeIs, Carlos, Direitos Humanos Contemporâneos, São Paulo, Malheiros, 2006, p. 39.

172 "Liberdade igual significa, por exemplo, não apenas o direito à inviolabilidade de domicílio, mas o direito a ter casa; não apenas o direito à vida e integridade física, mas também o acesso a cuidados médicos; não apenas o direito de expressão mas também a possibilidade de formar a própria opinião; não apenas direito ao trabalho e emprego livremente escolhido, mas também a efectiva posse de um posto de trabalho" in Canotilho, José Joaquim Gomes, Direito Constitucional ... cit., p. 470.

${ }^{173}$ Cf. LAFER, Celso, A Reconstrução dos... cit., p. 131.

${ }^{174}$ Cf. Bonavides, Paulo, Curso de... cit., p. 570.
} 
os autores que se utilizam de tal enunciado tenham efetivamente proposto uma relação de substitutividade entre as ondas de reconhecimento e positivação de direitos fundamentais.

Feita essa sintetização, cumpre ressalvar que, quanto ao objeto desta pesquisa - o direito à educação - é imperioso notar uma peculiaridade.

Na perspectiva da pluralidade de dimensões da educação e, por consequência, do próprio direito à educação, um dos aspectos que fica evidente a seu respeito é tratar-se de tema que transita livremente entre a esfera individual e a esfera pública. Isso significa que o direito à educação pode ser enfocado tanto como uma premissa de satisfação pessoal, mediante o desenvolvimento das capacidades individuais que o próprio sujeito-educando espera ver desenvolvidas, como pode ser visto como um elemento integrante do bem comum de determinada sociedade, voltado ao desenvolvimento social ${ }^{175}$. De modo que o direito à educação é peculiar porque possui elementos de mais de uma das dimensões de direitos fundamentais.

Assim ensina CAGGIANO, para quem o direito à educação está claramente presente na primeira e na segunda dimensões, uma vez que se apresenta como realidade social e individual. Em suas palavras "insuflado e robustecido pelos caracteres de índole coletiva, extraídos das duas últimas gerações de direitos, vislumbre-se o direito à educação com conteúdo multifacetado, envolvendo não apenas o direito à instrução como processo de desenvolvimento individual, mas, também, o direito a uma política educacional, ou seja, a um conjunto de intervenções juridicamente organizadas e executadas em termos de um processo de formação da sociedade, visando oferecer aos integrantes da comunidade social instrumentos a alcançar os seus fins" ${ }^{176}$.

Em verdade, o direito à educação impõe ao Estado obrigações de respeito, proteção e satisfação. Segundo ensina HOROWITZ ${ }^{177}$, respeitar o direito significa não violá-lo através

\footnotetext{
${ }^{175}$ Ver SIFUENTES, que, entre os objetivos do ensino fundamental estabelecidos no artigo 22 da Lei ${ }^{\circ}$ 9394/96, identifica duas ordens: "1. Educação para si - correspondente à meta de cada indivíduo no seu aperfeiçoamento pessoal, pelo desenvolvimento da capacidade própria de aprendizagem, a compreensão do ambiente natural, social e político em que vive, da tecnologia, artes e valores em que se fundamenta a sociedade. 2. Educação para o outro - com vistas à educação como prática social, como instrumento de aprimoramento da vida em sociedade. Nessa ótica, o legislador coloca como objetivos a serem alcançados o desenvolvimento da capacidade de aprender com vista à formação de atitudes e valores, além do fortalecimento dos laços familiares, da solidariedade e tolerância recíproca em que se assenta a convivência social" in SIFUENTES, Mônica, Direito Fundamental... cit., p. 40.

${ }_{176}$ Caggiano, Monica Herman S., A Educação. Direito Fundamental, in Ranieri, Nina Beatriz Stocco (coord.), Direito à Educação: Aspectos Constitucionais, São Paulo, EDUSP, 2009, p. 23.

${ }^{177}$ HoROwITZ, Jonathan Thompson, The Right to Education in Occupied Territories: Making More Room for Human Rights in Occupation Law, in Yearbook of International Humanitarian Law, v. 7, 2004, pp. 250 e 251.
} 
de ações deliberadas. Proteger é agir de forma a impedir que terceiros possam violá-lo. Já satisfazer compreende a adoção de medidas ativas no sentido de possibilitar a efetivação do direito. Cada uma dessas extensões, que permitem compreender que aos pais seja garantida a liberdade de escolha da educação a ser dada a seus filhos, que haja proteção penal contra a recusa de fornecimento de escolarização à prole ${ }^{178}$, e, também, que exista uma obrigação estatal de organizar sistemas e programas educacionais capazes de atender a todas as crianças e adolescentes em idade escolar, adicionalmente contribui para a complexidade de conceituação do direito à educação. Para HoROWITZ, ademais, esse direito conta, ainda, com outra característica que o torna único: "concede um direito e também torna esse direito de exercício compulsório para alguns indivíduos"179.

RANIERI sintetiza afirmando ser o direito à educação um direito que ao mesmo tempo é social, individual e coletivo, alternando-se, conforme a situação, os titulares e sujeitos passivos. É um direito que envolve um conjunto de obrigações jurídicas diversas, comportando obrigações de fazer e não fazer distintas segundo o sujeito passivo seja o Estado, a coletividade ou o próprio indivíduo. Conforme assevera a autora, "[s]eu regime jurídico, portanto, é complexo: envolve diferentes poderes e capacidades de exercício, com a inerente sujeição ao regime jurídico específico dos direitos fundamentais (...), mesmo dependendo de prestações materiais e de recursos financeiros" ${ }^{180}$.

Delimitada a premissa segundo a qual o direito à educação reúne diferentes dimensões, resta avaliar, ainda que sinteticamente, cada uma delas.

\subsubsection{O direito à educação em sua dimensão de liberdade individual.}

Nesta primeira dimensão ressaltam a laicidade e a liberdade de ensino, aspectos integrantes do direito à educação antes mesmo deste se conformar como direito a prestações positivas. Trata-se da perspectiva referida por TAVARES como a "dimensão nãoprestacional do direito à educação, consistente no direito de escolha, livre, sem interferências do Estado, quanto à orientação educacional, conteúdos materiais e opções

\footnotetext{
${ }^{178}$ No caso brasileiro o crime de abandono intelectual, previsto no artigo 246 do Código Penal (Decreto Lei no 2.848/40), in verbis: “Art. 246 - Deixar, sem justa causa, de prover à instrução primária de filho em idade escolar. Pena - detenção, de quinze dias a um mês, ou multa".

${ }^{179}$ Horowitz, Jonathan Thompson, The Right to Education... cit., pp. 250 e 251.

${ }^{180}$ RANIERI, Nina Beatriz Stocco, O Estado Democrático... cit., p. 286.
} 
ideológicas"181 . A satisfação do direito à educação, nessa dimensão, se dá pela abstenção estatal em impor uma religião oficial nos estabelecimentos de ensino, em definir versões da história ou em restringir a pluralidade de conteúdos.

Conforme ensina CAGGIANO, o direito à instrução constou das declarações de direitos de liberdade, tal como no preâmbulo da Declaração dos Direitos do Homem e do Cidadão de 1789 e da Declaração Jacobina de 1793. Também na Constituição Francesa de 1795, que em seu artigo 300 previu o direito dos cidadãos de estabelecerem livremente estabelecimentos particulares de educação ${ }^{182}$. Sua feição nesses documentos era de liberdade individual, ligada às idéias de liberdade de informação e de manifestação do pensamento.

Recorde-se que no Antigo Regime a instrução, como as demais prerrogativas feudais, era para poucos, e, com algumas exceções no ambiente universitário, quase integralmente controlada pela Igreja. De modo que no momento do amanhecer republicano, na ruptura definitiva com as instituições feudais, a educação foi tida como instrumento liberador, da mesma forma que os direitos civis.

Nesse sentido, basta recordar que os fundamentos da defesa de CONDORCET à educação pública eram, antes de tudo, fundamentos de defesa dos valores republicanos contra a interferência da Igreja e das instituições absolutistas. Considerado o momento, era natural que o caráter fosse mesmo liberatório. CONDORCET viu na educação pública o modo de forjar entre o povo a igualdade necessária à liberação da tirania e à igualdade real de direitos. Nesse contexto, afirmou que "quando a lei fez dos homens todos iguais, a única distinção que permaneceu dividindo-os em diversas classes foi a sua educação" (tradução livre) $)^{183}$.

Em seu discurso CONDORCET esclareceu que apenas a educação como res publica, conduzida pela sociedade, poderia impedir que as luzes do conhecimento concentrassem-se em classes pouco numerosas, e assim servissem de instrumento de dominação. Em suas palavras, "[o]s padres, os jurisconsultos, os homens que possuíam o segredo das operações de comércio, os próprios médicos formados num pequeno número de escolas não eram

181 Tavares, André Ramos, Direito Fundamental à Educação, in SouZA NeTO, Cláudio Pereira de, e Sarmento, Daniel (coords.), Direitos Sociais: Fundamentos, Judicialização e Direitos Sociais em Espécie, Rio de Janeiro, Lumen Juris, 2008, p. 777.

182 "Article 300. - Les citoyens ont le droit de former des établissements particuliers d'éducation et d'instruction, que des sociétés libres pour concourir aux progrès des sciences, des lettres et des arts"

${ }^{183}$ CONDORCET, Marquis de (Marie Jean Antoine Nicola de Caritat), Premier Mémoire sur L'instruction Publique (1791), Paris, Mille et une nuits, 2002, p. 10. 
menos mestres do mundo que guerreiros inteiramente armados; e o despotismo hereditário daqueles guerreiros estava fundado na superioridade que lhes conferia, antes da invenção da pólvora, seu conhecimento exclusivo da arte de manejar as suas armas"184 (tradução livre). No ideário republicano do século XVIII educação livre e provida igualmente a todos, retirada do clero e das corporações, era imperativa para o fim da servidão.

Todavia, a despeito da clareza presente no momento da ruptura com o antigo regime, o tema da laicidade, o da atividade educacional pública e o da liberdade de ensino tornam-se uma questão de profunda complexidade em face do próprio ideal liberalrepublicano. Ao mesmo tempo em que se necessita da educação para a viabilização das instituições republicanas e democráticas, também é necessário delimitar-se bem o limite da interferência do próprio Estado no ensino, sobretudo no que diz respeito à absoluta neutralidade em matéria de consciência. Em diversos momentos da história mundial recente, uma dita educação de Estado foi utilizada com os mais terríveis fins, inclusive no Brasil $^{185}$.

A laicidade foi das conquistas mais importantes para o desenvolvimento da República e do próprio Estado de Direito. Mas não deve ser objeto de abuso, nem mal interpretada, algo que conflitaria com a própria prevalência da liberdade do ideal republicano. Proibir o ensino religioso, suprimindo a liberdade para a Igreja, implicaria tão simplesmente suprimir a liberdade e, por decorrência lógica, uma renúncia ao liberalismo $\mathrm{em} \mathrm{si}^{186}$.

Sobre isso, vale a anotação da lição de CURY, para quem "[a] laicidade, ao condizer com a liberdade de expressão, de consciência e de culto, não pode conviver com um Estado portador de uma confissão. Por outro lado, o Estado laico não adota a religião da irreligião ou da anti-religiosidade. Ao respeitar todos os cultos e não adotar nenhum, o Estado libera as igrejas de um controle no que toca è especificidade do religioso e se libera do controle religioso" 187 .

Do mesmo modo, de nada adiantaria o desmantelamento de um dogmatismo anterior para adoção de um novo dogmatismo. Um dogmatismo religioso substituído por um dogmatismo de Estado. De modo que o surgimento da liberdade de ensino se dá como

\footnotetext{
${ }^{184}$ CONDORCET, Marquis de (Marie Jean Antoine Nicola de Caritat), Premier Mémoire... cit., p. 9.

${ }^{185}$ Ver FAUSTO, Boris, O Pensamento... cit..

${ }^{186}$ Cf. PrÉlot, Pierre-Henri, La Séparation des Églises et de l'État, in Revue du Droit Public, t. 122, n. 3, 2006, p. 625.

${ }^{187}$ CURY, Carlos Roberto Jamil, Ensino religioso na escola pública: o retorno de uma polêmica recorrente, in Revista Brasileira de Educação, n. 27, 2004, p. 183.
} 
uma necessidade prática diante da possibilidade de sua negação pela própria autoridade estatal. Nesse sentido, o direito à educação enquanto liberdade de ensinar e de aprender apresenta-se como direito civil, típico da primeira dimensão de direitos fundamentais.

Trata-se de uma realidade do direito à educação que muitas vezes resta desapercebida na atualidade, uma vez que se habitou a encará-lo unicamente através do prisma das imposições de concretização e regulação que esse direito também cria ao Estado, prisma que indubitalvelmente prevalece. No entanto, conforme ensinam ABRAMOVICH e COURTIS ${ }^{188}$, o Estado assume um duplo perfil em relação a todo direito, integre ele o conjunto das liberdades civis ou o dos ditos direitos sociais.

Por um lado, o poder público assume obrigações de abstenção ou obrigações negativas, no sentido de uma imposição ao Estado de evitar lesar ou ameaçar de lesão os direitos dos particulares. Por outro lado, também sempre assume obrigações positivas (ou de ação), também chamadas de obrigações de concretização e regulação, consistentes na definição de condições e consequiências do exercício dos direitos. Embora quanto às liberdades civis prevaleça o primeiro perfil, ao qual se está habituado, também é necessária a atuação estatal no sentido de regular e concretizar. São exemplos a criação e a manutenção de serviços notariais e de registro para o exercício da propriedade imóvel, a criação e a manutenção de juntas comerciais e cartórios de protesto para as atividades societárias e mercantis, a organização de uma justiça eleitoral para o exercício dos direitos políticos etc.

E também é verdade que, quantos aos direitos sociais, sempre subsistem obrigações negativas: "o Estado deve abster-se de atingir indevidamente a saúde, a educação, o trabalho, a previdência etc. (...) É dizer, todo direito social supõe também uma dimensão de liberdade ou autonomia frente à ingerência arbitrária do poder público" ${ }^{189}$ (tradução livre).

$\mathrm{O}$ assunto é cotidiano e relaciona-se com inúmeras fontes de complexidade, como o homeschooling, os direitos dos pais quanto à educação de seus filhos, os direitos dos estudantes e o ensino religioso, algumas das quais serão revisitadas mais adiante.

\subsubsection{O direito à educação como direito social.}

\footnotetext{
188 ABrAmovich, Víctor e COURTIS, Christian, El Umbral de la Ciudadanía. El significado de los derechos sociales em el Estado social constitucional, Buenos Aires, Del Puerto, 2006, pp. 8 a 10.

${ }^{189}$ ABRAMOVICH, Víctor e CourTis, Christian, El Umbral de... cit., p. 24.
} 
Como mencionado, não há dúvida de que em relação ao direito à educação prevalece a dimensão social, ou seja, preponderam as obrigações de ação do Estado. No caso brasileiro, isso se explica facilmente diante da realidade econômica e social do país e do panorama jurídico que o constituinte organizou em resposta.

Conforme visto na exposição sobre o pensamento de MARSHALL, a crescente incorporação aos ordenamentos de obrigações estatais positivas tem seu ponto de partida mais emblemático nas lutas de aprimoramento das condições dos trabalhadores da sociedade industrial do século XIX e na percepção de que a aplicação de noções jurídicas típicas dos ordenamentos liberais às relações laborais produzia distorções insustentáveis. Constatou-se que desigualdades materiais e de diferenças de oportunidade obstaculizam a satisfação das necessidades pessoais através unicamente da livre atuação individual no mercado. Isso impele o Estado a modificar seu papel e assumir, direta ou indiretamente, um grande número de obrigações que até então se inseriam exclusivamente na esfera da autonomia privada individual.

Segundo ensinam ABRAmovich e COURTIS ${ }^{190}$, essa modificação supõe um novo modelo normativo, diferente do modelo liberal anterior por (i) caracterizar um direito de grupos e não de indivíduos, em que os direitos dos indivíduos diferem segundo os grupos sociais a que pertençam (empregados, empregadores, mulheres, crianças, indígenas, portadores de deficiências etc.); (ii) constituir um direito de desigualdades, organizando-se a partir da identificação das desigualdades existentes entre os diversos grupos sociais para, então, buscar sua eliminação ou redução; e (iii) achar-se ligado a uma sociologia (ou avaliação sociológica), que lhe serve de instrumento necessário na identificação dos grupos sociais com menores oportunidades, das relações sociais pertinentes a tais grupos, de suas necessidades etc. Essa nova estrutura normativa, que expande os limites de atuação do direito, extravasando o foco no indivíduo, permite compreender os direitos sociais como utilização do poder estatal para atenuar situações de desigualdade material e para equilibrar as oportunidades.

Assim, o direito à educação enquanto direito social (ou eminentemente de caráter social) traduz uma imposição de ação ao Estado quanto à regulação da atividade educacional e quanto ao fornecimento de prestações que possibilitem a todos a

\footnotetext{
${ }^{190}$ ABRAMOVICH, Víctor e COURTIS, Christian, El Umbral de... cit., pp. 15 e 16.
} 
concretização do direito. No caso brasileiro, conforme ensina SILVA ${ }^{191}$, este é o sentido a ser extraído da declaração constitucional de que a educação é "direito de todos e dever do Estado e da família", constante dos artigos 205 e 227. Assim declarando, a Constituição Federal de 1988 determina que o Estado proceda ao aparelhamento suficiente para fornecer serviços educacionais a todos; que amplie, continuamente, as condições para que todos exerçam igualmente o direito; e que todas as normas relacionadas à atividade educacional sejam interpretadas segundo aquela declaração.

CANOTILHO $^{192}$ afirma que os direitos sociais constituem autênticos direitos subjetivos inerentes à própria existência digna do indivíduo. Disso decorre o seu caráter prestacional, uma vez que, assim considerados, deles decorre um dever simultâneo do Estado de criação de condições materiais de exercício e uma aptidão do indivíduo para exigir as prestações que lhe são devidas.

Trata-se do notório jargão: a todo direito corresponde um dever, que pode ser de abstenção ou de ação, ou de ambos. Ao se reconhecer o direito à prestação positiva exigível em face do Estado, pode-se falar em direito público subjetivo. O tema da efetividade do direito subjetivo à educação será explorado mais adiante.

Mas aqui se volta ao problema inicial: há clareza acerca de quais sejam as obrigações de ação do Estado? Há clareza quanto à estrutura normativa que o Estado deve instituir através do legislador e da regulamentação executiva? Há clareza sobre que tipo de prestação desincumbe o Estado de seu dever constitucional de concretizar o direito à educação? Há clareza quanto ao que o cidadão pode exigir de modo a ver satisfeito o próprio direito? São questões essenciais ao exercício do direito à educação.

O Comitê de Direitos Econômicos, Sociais e Culturais da Organização das Nações Unidas e TOMASEVSKI, na posição de Relatora Especial sobre o Direito à Educação, propuseram um modelo de solução. Trata-se do Comentário Geral $n^{\circ} 13$ ao já citado Pacto Internacional sobre Direitos Econômicos, Sociais e Culturais de 1966. O propósito do documento é justamente definir o conteúdo normativo do também já mencionado artigo 13 do Pacto. Nesse sentido, concebe o direito à educação como sendo composto por quatro elementos: disponibilidade, acessibilidade, aceitabilidade e adaptabilidade, cujos termos compreenderiam o seguinte:

\footnotetext{
${ }^{191}$ Silva, José Afonso da, Curso... cit., p. 313.

${ }^{192}$ CAnotilho, José Joaquim Gomes, Direito Constitucional ... cit., pp. 467 e 468.
} 
“(a) Disponibilidade - instituições e programas educacionais em funcionamento têm de ser disponíveis em quantidade suficiente no interior da jurisdição do Estado parte [signatário do Pacto]. $\mathrm{O}$ que eles requerem para funcionar depende de inúmeros fatores, incluindo as condições de desenvolvimento dentro das quais operam; por exemplo, todas instituições e programas necessitam de prédios ou outra forma de proteção dos elementos naturais, instalações sanitárias para ambos os sexos, água potável, professores treinados recebendo salários domesticamente competitivos, materiais de ensino e aprendizagem, e assim por diante; enquanto alguns ainda precisarão de mais instalações como biblioteca, salas de informática e tecnologia da informação;

(b) Acessibilidade - instituições e programas educacionais devem ser acessíveis a todos, sem discriminação, dentro da jurisdição do Estado parte. Acessibilidade abrange três dimensões sobrepostas:

(i) Não-discriminação - a educação deve ser acessível a todos, especialmente àqueles grupos mais vulneráveis, de direito e de fato, sem discriminação nas formas proibidas [conforme parágrafos 31 a 37 do Comentário Geral];

(ii) Acessibilidade física - a educação deve poder ser alcançada de modo seguro, seja por frequiência a locação razoavelmente conveniente do ponto de vista geográfico (por exemplo uma escola na vizinhança), seja através de tecnologias modernas (por exemplo a participação de programas de ensino à distância);

(iii) Acessibilidade econômica - a educação deve estar ao alcance financeiro de todos. Esta dimensão da acessibilidade é sujeita a diferentes tratamentos pelo artigo 13 (2) conforme se trate de educação primária, secundária ou superior: enquanto a educação primária deve ser 'gratuita a todos', os Estados partes deverão progressivamente introduzir a educação secundária e a superior gratuita;

(c) Aceitabilidade - a forma e a substância da educação, incluindo currículo e métodos de ensino, têm de ser aceitáveis (ou seja, relevantes, culturalmente apropriadas e de boa qualidade) para estudantes e, nos casos apropriados, pais; isso está submetido aos objetivos da educação conforme estipulados pelo artigo 13 (1) e a padrões educacionais mínimos tais como estejam estipulados pelo Estado (artigo 13 (3) e (4));

(d) Adaptabilidade - a educação deve ser flexível de modo a poder adaptar-se às necessidades de sociedades e comunidades dinâmicas e a responder às necessidades dos estudantes quanto à diversidade de seu contexto social e cultural." ${ }^{193}$ (tradução livre)

Como se observa, na dimensão de direito social, o direito à educação poderia ser sintetizado como imposição ao Estado de duas grandes linhas de obrigação positiva: (i) uma atividade interventiva legiferante, porque sendo o responsável final pelo direito cumpre-lhe regulá-lo e fiscalizá-lo quando não o preste diretamente, além de prever e

193 OrganizaÇão das Nações Unidas, Comitê de Direitos Econômicos, Sociais e Culturais, General Comment 13: The Right to Education, 1999. 
viabilizar instrumentos jurisdicionais de tutela; e (ii) uma imposição de disponibilização de uma educação acessível, aceitável e adaptável a todos que não possam ou não queiram satisfazer-se por seus próprios meios. Esclareça-se, como faz RANIERI ${ }^{194}$, que, justamente pelo caráter social, essa prestação estende-se à atenção às diferenças existentes entre os diversos grupos sociais, tarefa da qual o Estado se desincumbe ao proporcionar educação preparada para atender alunos regulares e com necessidades especiais, educação de jovens e de adultos, educação direcionada à cultura indígena etc.

Porém, embora contribuam para a necessária delimitação jurídica do direito e do dever envolvidos no direito à educação, essas constatações teóricas ainda não exaurem o tema. Trata-se, sem dúvida, de um ponto de partida de grande relevância, inclusive por representar obrigações internacionalmente assumidas pela maioria dos países ${ }^{195}$. Todavia, entende-se, nesta Dissertação, que a delimitação final do conteúdo jurídico do direito à educação somente pode ser atingida mediante a investigação do sistema jurídico positivo. Significa dizer que a formatação final do direito à educação e do modo de seu exercício somente pode ser definida em relação a determinado ordenamento jurídico.

Partindo-se da premissa de que, eminentemente desde a Declaração Universal dos Direitos do Homem, a titularidade dos direitos fundamentais possui previsão que extravasa as fronteiras nacionais, aos Estados impõe-se a tarefa de procederem ao detalhamento desses direitos, de modo a concretizar seu exercício, como exigência de cidadania. Tal detalhamento de exercício, certamente, condiciona o conteúdo do direito.

O Capítulo III deste trabalho é dedicado à análise de como se dá esse detalhamento quanto ao direito à educação no sistema jurídico positivo brasileiro ${ }^{196}$.

\subsubsection{A dimensão coletiva do direito à educação: sua relação com o bem} comum.

\footnotetext{
${ }^{194}$ Conforme afirma a autora, "[o] dever do Estado, em particular, não se esgota no oferecimento e financiamento final da educação, pelo contrário; deve prover todos os meios necessários para que o direito esteja a todos disponível, seja acessível, adequado às necessidades sociais e adaptado às necessidades do indivíduo" in RANIERI, Nina Beatriz Stocco, O Estado Democrático... cit., p.288.

${ }^{195}$ O Pacto Internacional sobre Direitos Econômicos, Sociais e Culturais de 1966 foi incorporado pelo Decreto $\mathrm{n}^{\circ}$ 591, de 06 de julho de 1992.

${ }^{196}$ Conforme esclarece TAVARES, o conteúdo mínimo do direito à educação consiste no direito ao processo formativo oferecido de forma regular e organizada, que atenda à determinações constitucionais específicas a essa atividade. Nas palavras do autor: "[n]ão se trata mais de qualquer direito à educação, mas daquele cujas balizas foram construídas constitucionalmente. Isso significa que o direito à educação é o direito de acesso, mas não um acesso a qualquer educação, e sim àquela que atende às preocupações constitucionais" in TAVARES, André Ramos, Direito Fundamental... cit., p. 775.
} 
Afirmou-se acima que a razão de ser da excepcionalidade do direito à educação consiste no fato de ele ser uma parte da vida humana em sociedade que transita livremente entre a esfera individual, seja como liberdade, seja como decorrência da dignidade, e a esfera coletiva. E nesta relação com a coletividade, o direito à educação é componente inafastável da noção de bem comum enquanto finalidade do Estado.

Bem comum aqui é concebido dentro da concepção tomista-aristotélica. Ou seja, é encarado dentro de uma concepção orgânica da sociedade, como se esta fosse um organismo vivo, e, como tal, tendente ao seu próprio bem. Nessa perspectiva, o bem da sociedade configura um guia da ordem jurídica, de modo que todo o ordenamento e todas as ações públicas devem estar voltados à promoção desse bem comum ${ }^{197}$.

Logo no início da Política, ARISTÓTELES afirma que "a observação nos mostra que cada Estado é uma comunidade estabelecida com alguma boa finalidade, uma vez que todos sempre agem de modo a obter o que acham bom. Mas, se todas as comunidades almejam o bem, o Estado ou comunidade política, que é a forma mais elevada de comunidade e engloba tudo o mais, objetiva o bem nas maiores proporções e excelência possíveis ${ }^{198,}$.

Na percepção de SÃo TOMAS DE AQUINO, por sua vez, a própria idéia de direito requer o direcionamento ao bem comum, relacionado ao alcance do bem que propicie a felicidade temporal, em função da completa realização de uma finalidade extra-terrena. $\mathrm{O}$ Estado, de seu turno, possuiria a principal função de permitir a conquista desses fins ${ }^{199}$.

Conforme ensina DESWARTE ${ }^{200}$, todo homem procura em suas ações um bem desejado, que pode ser espiritual, material, sentimental etc. No entanto, o homem é ser associativo, fator que conhece racionalmente e não apenas por instinto como outros animais gregários, de modo que não lhe serve nem basta empenhar-se apenas por seu próprio bem. Deve defender também o bem do grupo social em que se encontra. Este é o bem comum de toda sociedade, fundamentado na relação de complementaridade existente

\footnotetext{
${ }^{197}$ Cf. Deswarte, Marie-Pauline, Intérêt General, Bien Commun, in Revue du Droit Public et de la Science Politique en France et a L'Étranger, n. 5, Paris, 1988, p. 1293.

198 ARISTÓteles , A Política, in Aristóteles, col. Os Pensadores, São Paulo, Nova Cultural, 1999, p. 143.

199 Cf. D'EnTREVÈs, Alessandro Passerin, La nocion de Estado, Uma introducción a la Teoria Política, Barcelona, Ariel, 2001, p. 262.

${ }^{200}$ DeSWARTE, Marie-Pauline, Intérêt ... cit., p. 1294.
} 
entre os seres humanos, e cuja satisfação é, portanto, dever tanto do Estado como de todos individualmente.

Certamente, a forma como o bem comum de determinada sociedade será promovido (e se será) está intimamente relacionada à educação de seus membros. Tamanha a relevância da educação, que MONTESQUIEU ${ }^{201}$ a relaciona como um elemento de organização do Estado, entendendo, por exemplo, não ser possível o estabelecimento de uma República sem que haja uma educação republicana.

Com esse espírito, os iluministas por trás da Revolução Francesa de 1789 e da Revolução Americana de Independência, publicistas como RUSSEAU, DIDEROT, Condorcet, LeClerc, Benjamin Rush, Thomas JefFerson e, posteriormente, Horace MANN, confiavam que um sistema educacional público, de integração compulsória, seria capaz de criar um novo povo, indispensável para as novas Repúblicas que se formavam. A educação pública substituiria ou pelo menos contrabalancearia aquela professada pelas Igrejas Católica e Protestantes e seria caminho necessário para atingir-se a liberdade e a felicidade da nação ${ }^{202}$. Nessa perspectiva, concebeu-se que a atividade não podia mesmo ser deixada às disponibilidades privadas individuais, tanto no oferecimento quanto no recebimento do ensino. Constatou-se ser imperativo que o Estado, ao assumir forma e valores republicanos, assumisse também, integralmente, a responsabilidade pela prestação educacional a todas as crianças, estabelecendo tanto o direito como o dever à educação.

Quanto à educação existe um direito subjetivo combinado com uma obrigação pública de exercer o direito. Diante dessa assertiva MARSHALL ${ }^{203}$ questiona: seria tal obrigação pública imposta tão somente em benefício da pessoa, diante de um eventual prejuízo às crianças provocado pela possível inaptidão de seus pais em instruí-las? A resposta do autor: certamente não.

A satisfação do direito à educação excede a esfera individual: beneficia, evidentemente, o indivíduo, mas vai além e enriquece toda a sociedade. MARSHALL é claro nesse sentido: "[à] medida que se iniciava o século $\mathrm{XX}$, tornou-se cada vez mais evidente a noção de que a democracia política precisava de um eleitorado educado, e que a

${ }^{201}$ Cf. Comparato, Fabio Konder, Educação, Estado e Poder, São Paulo, Brasiliense, 1987, p. 91. COMPARATO também afirma: "parece inevitável considerar que educação e política, a ação política e a ação educacional são fatores reciprocamente condicionantes" in idem, p. 94.

${ }^{202}$ Para uma coleção de trechos dos iluministas do século XVIII acerca da essencialidade do direito à educação pública assegurado pelo Estado para persecução dos fins republicanos ver GLENN JR., Charles Leslie, The Myth of the Common School, Oakland, Institute for Contemporary Studies, 2002, pp. 88 a 97.

${ }^{203}$ MARSHALL, Thomas Humphrey, Ciudadania ... cit, p. 311. 
manufatura científica precisava de trabalhadores e técnicos qualificados. A obrigação de melhorar-se e civilizar-se é, portanto, uma obrigação social, e não meramente pessoal, porque a saúde social de uma sociedade depende da civilização de seus membros"204 (tradução livre).

A mesma linha de raciocínio pode ser vista, atualmente, em DUARTE, para quem “embora a educação, para aquele que a ela se submete, represente uma forma de inserção na cultura e mesmo um bem individual, para a sociedade que a concretiza, ela se caracteriza como um bem comum, já que representa a busca pela continuidade de um modo de vida que, deliberadamente, se escolhe preservar" ${ }^{\text {205. }}$.

Porque interessa à democracia e aos ideais republicanos, porque interessa ao desenvolvimento da sociedade, chame-se de bem comum ou saúde social, fato é que a educação necessariamente interessa ao Estado e consagra instrumento de ação política, conforme ressalta RANIERI ${ }^{206}$. Nessa perspectiva, educação e direito à educação possuem natureza pública por excelência, ou seja, natureza pública decorrente de sua essência.

A isso tudo se prende a necessidade de se reconhecer uma vertente transindividual (difusa ou coletiva) do direito à educação, porque tutela interesses da coletividade, ou seja, de um número de sujeitos de difícil ou impossível determinação. Isso significa que a própria titularidade do direito, além de individual, é também social ${ }^{207}$. Ao satisfazer o direito à educação de uma criança, o Estado está satisfazendo, na verdade, uma pretensão de todo corpo social. Neste aspecto o direito à educação possui especialidade em relação a outros ditos direitos sociais, porque nele esse caráter transcendental é mais evidente.

Todos têm direito à saúde, à previdência e a condições de trabalho justas porque essas são decorrências óbvias da dignidade humana, que aponta para a imperatividade de correções de desigualdade material. O direito à educação, de seu turno, decorre tanto da

\footnotetext{
${ }^{204}$ MARSHALl, Thomas Humphrey, Ciudadania ... cit, p. 311.

${ }^{205}$ DuARTE, Clarice Seixas, A Educação como um Direito Fundamental de Natureza Social, in Educação e Sociedade, Campinas, v. 28, n. 100, 2007, p. 697.

${ }^{206}$ RANIERI, Nina Beatriz Stocco, Educação Superior, Direito e Estado na Lei de Diretrizes e Bases (Lei $n$. 9.394/96), São Paulo, EDUSP, 2000, pp. 37 e 38.

${ }^{207}$ Em passagem sobre a relação entre direito à educação e direito ao desenvolvimento RANIERI afirma: "[o] direito à educação no Brasil é direito subjetivo público, obrigação de comportamento (...). Ao Estado é imposta a tarefa de criar condições para que os indivíduos, em situação de igualdade de oportunidades, atinjam e realizem seus objetivos; e, por via de conseqüência, alcancem o desenvolvimento no nível pessoal e no coletivo, como exigência da época e do contexto social em que vivemos" (grifo ausente no original) in RANIERI, Nina Beatriz Stocco, Direito ao Desenvolvimento e Direito à Educação - Relações de Realização e Tutela, in Revista dos Tribunais, a. 2, n. 6, 1994, p. 127.
} 
dignidade como da própria concepção de Estado (cuja principal finalidade é buscar o fim comum) com a mesma obviedade.

Decidir entre um sistema de saúde que privilegie tratamentos de ponta para um número reduzido de pessoas em detrimento de programas de saúde básica para um grande número de pessoas ou um sistema de saúde que privilegie programas de saúde básica para muitos em detrimento de tratamentos de ponta para poucos certamente remete a autoridade pública a uma esfera de discricionariedade administrativa de solução extremamente complexa. Por um lado, o alto custo de tratamentos de vanguarda torna-os inacessíveis à maior parte das pessoas, que, com menor esforço poderiam custear a própria saúde básica; por outro lado, um número maior de pessoas necessita de cuidados de saúde básica, que, inclusive, muitas vezes podem diminuir o número de situações que demandem tratamentos caros.

Já quanto à educação, inexiste esta complexidade: permitir que uma só criança fique sem escola é diminuir o potencial de desenvolvimento da sociedade, sendo, portanto, contraditório à própria finalidade do Estado. Mesmo sociedades liberais, como a norteamericana, onde o bem comum na área da saúde tradicionalmente consistiu na não intervenção estatal direta, compreenderam há muito que a responsabilidade do Estado pela educação de todos constituía parte imprescindível da lógica da ação pública ${ }^{208}$.

A despeito de sua fundamentalidade, enquanto decorrência da dignidade humana reconhecida e positivada na ordem internacional e na maioria das ordens nacionais, $\mathrm{o}$ direito à educação conta com um caráter instrumental muito mais evidente do que se passa com outros direitos sociais. Sob o prisma da instrumentalidade, a educação é um investimento importante. Essa conclusão é o que atribui lógica, por exemplo, à posição do governo norte-americano de garantir educação básica pública para todos, enquanto mantém a tradicional postura de negar que prestações típicas do modelo de Estado de Bem Estar Social constituam direitos.

Esse argumento é anotado por ALSTON e BUTHA ${ }^{209}$. Segundo os autores, ainda que se afaste o discurso dos direitos fundamentais, o direito à educação é inteiramente defensável mediante fundamentos econômicos. Isso quer dizer que, ao invés de ser

${ }^{208}$ Cf. GLEnN JR., Charles Leslie, The Myth of the Common School, Oakland, Institute for Contemporary Studies, 2002.

${ }^{209}$ ALSTON, Philip et BHUTA, Nehal, Human Rights and Public Goods: Education as a Fundamental Right in India, in Alston, Philip et ROBInson, Mary, Human Rights and Development: Towards Mutual Reinforcement, Oxford, Oxford University Press, 2005, pp. 245 a 248. 
concebida apenas como uma demanda social (demand), a educação deve ser vista sob a forma de insumo (supply), cujo custo (education supply - custo de construção de escolas, de contratação e treinamento de professores e de fornecimento de materiais de ensino) é pequeno relativamente aos benefícios obtidos em termos de aprimoramento da produtividade e de ganho de capacidade associados à ampliação da educação ${ }^{210}$. Além do benefício econômico direto, os autores advertem que a educação é também um bem social indispensável ao desenvolvimento humano, ao crescimento econômico sustentável e à redução da pobreza, uma vez que pode ser ligado à melhoria nas condições de saúde, à redução do crescimento populacional, ao fortalecimento da democracia, à boa governança e à segurança da sociedade.

Com esse caráter de bem público essencial, a satisfação do direito à educação permeia os próprios fundamentos do Estado, já que está intimamente ligada à sua finalidade. É lícito concluir ser plenamente defensável que o direito à educação impõe uma obrigação lógica ao poder público, e, portanto, inexorável.

Além do Estado, o caráter coletivo do direito à educação submete o indivíduo, que é o seu titular. A contrapartida ao fato de beneficiar tanto o indivíduo como a coletividade é que o direito à educação também obriga a ambos. De modo que além de credor do direito à educação, o indivíduo é subordinado a um dever jurídico de educar-se. Conforme ensina RANIERI, o benefício recíproco ao indivíduo e à coletividade explica por que, diferentemente de outros direitos sociais, o direito à educação seja "compulsório (pelo menos nos primeiros níveis de ensino), não sendo dada aos indivíduos [...] a opção de exercê-lo ou não"211.

Além da obrigatoriedade de escolarização, o caráter de bem coletivo que possui o direito à educação impõe outras limitações à autonomia privada no âmbito educacional.

\footnotetext{
${ }^{210}$ Esses são os termos de um estudo realizado pela Organização Internacional do Trabalho acerca dos custos e benefícios da eliminação do trabalho infantil, no qual a universalização da educação ocupa lugar de destaque. Segundo o relatório, ações voltadas à universalização da educação de crianças até a idade de 14 anos, enquanto mecanismo de eliminação do trabalho infantil, importariam, numa projeção à América Latina entre os anos de 2000 a 2020, um custo 38,7 bilhões de dólares, aí embutido o sugerido para o aumento da qualidade da educação, que compreende relação aluno-professor e aluno-sala de aula à razão de 40:1 e estabelecimento de um gasto mínimo com livros e outros materiais de ensino não inferior a $15 \%$ do orçamento da educação. Em contrapartida, os benefícios obtidos no mesmo período seriam da ordem de 403,4 bilhões de dólares. Numa passagem, o relatório afirma: "[t]he single most important result is that the elimination of child labour and its replacement by universal education is estimated to yield enormous economic benefits - in addition, of course, to the social and intrinsic benefits that make this issue so salient. Globally, benefits exceed costs by a ratio of 6.7 to 1 " in ORGANIZAÇão INTERNACIONAL DO TRABALHO, Investing in Every Child: An Economic Study of the Costs and Benefits of Eliminating Child Labour, Genebra, ILO, 2003, pp. 4 e 67.

${ }^{211}$ RANIERI, Nina Beatriz Stocco, O Estado Democrático... cit., pp. 287288.
} 
Trata-se, por exemplo, de limitações referentes à regulação de períodos mínimos de ensino, à necessidade de exames de admissão a graus superiores de ensino, ao estabelecimento de conteúdos mínimos de ensino, entre outras.

\subsection{Conclusão parcial.}

Definiu-se, inicialmente, que esta Dissertação analisa o direito à educação enquanto direito a um processo formativo organizado institucionalmente, ou seja, direito à educação oferecida em estabelecimentos oficiais ou não oficiais de ensino, subordinados ao controle direito (prestação direta) ou indireto (autorização e fiscalização) do Estado. Verificou-se também que normas constitucionais (artigo 205 da Constituição Federal de 1988) e internacionais (artigo 13 do Pacto Internacional dos Direitos Econômicos, Sociais e Culturais de 1966 e artigo 29 da Convenção da Criança) tendem a vislumbrar um conteúdo teleológico para o direito à educação. Restou, todavia, uma preocupação: de que modo deve ser esse processo formativo institucional a que se tem direito? Qual o seu objeto? Essas perguntas poderiam, ainda, ser formuladas de maneira mais simples: como deve ser exercido o direito à educação?

Deve-se retomar que o exercício de um direito fundamental, cuja titularidade é, hoje, garantida desde a ordem internacional, constitui uma exigência de cidadania. Vale dizer, a sociedade politicamente organizada na forma de Estado deve propiciar que aqueles que com ela guardem uma relação de pertencimento (seus cidadãos) possam materializar (exercer) os seus direitos fundamentais. É à história dessa materialização, quanto ao direito à educação, que se dedicará o Capítulo III desta Dissertação, pois somente ela pode responder satisfatoriamente às perguntas indicadas. Em vista disto, também, é que foram acertados alguns significados ao longo deste capítulo.

A explanação teórica sobre a estrutura do direito à educação (de suas dimensões) serve de suporte para uma verificação dogmática subseqüente. Isso significa que o espírito de cada uma de suas dimensões, das afirmações de liberdade típicas do liberalismo revolucionário ao caráter coletivo da educação enquanto bem comum, pode servir de ponto de partida para a análise das normas que materializam o direito à educação em determinada ordem jurídica. 
Ressalte-se que esse domínio sobre o detalhamento normativo positivado é essencial porque é no âmbito do direito positivo (e de sua aplicação) que se pode conhecer a real amplitude do exercício do direito à educação, adquirindo-se, assim, maior clareza quanto ao seu conteúdo normativo. É no plano do regramento concreto que se descobre qual é, efetivamente, o processo formativo institucional a que se tem direito. Essa descoberta demonstrará qual é, no âmbito de determinada sociedade, o processo formativo que satisfaz o direito à educação, atendendo a uma exigência de cidadania. Nesse sentido, o paradigma mais importante é, sem dúvida, o mais tangível e expressivo dos acordos sociais: a Constituição que rege aquela sociedade. A seguir, portanto, passa-se ao estudo do direito à educação, conforme estabelecido pela Constituição Federal brasileira de 1988. 


\section{SOBRE O DIREITO POSITIVO À EDUCAÇÃO}

\subsection{Dimensão social.}

Certamente, é na dimensão de direito social que o direito à educação possui maior expressividade, pois é nela, também, que sua concretização enfrenta os maiores desafios.

\subsubsection{Parâmetros de vinculação e efetivação.}

O problema do exercício do direito à educação na sua dimensão social, exigência da cidadania nacional, impõe a compreensão esclarecida da estrutura assumida por esse direito dentro do ordenamento jurídico. Sobre o tema, a lição de CANOTILHO ${ }^{212}$ é de grande auxílio.

O autor ensina que os direitos sociais possuem duas dimensões: a dimensão objetiva e a dimensão subjetiva. A dimensão subjetiva é relativa ao conteúdo que esses direitos representam no espaço existencial do indivíduo. Ou seja, representa o conteúdo que se incorpora ao âmbito de titularidade do sujeito, pelo que se pode afirmar que os direitos sociais são direitos que também possuem dignidade subjetiva, do mesmo modo como os direitos e liberdades civis e políticos.

A dimensão objetiva, por sua vez, consiste na dimensão da operatividade prática dos direitos sociais. Neste ponto, segundo CANOTILHO, encontram-se as diferenças entre os direitos sociais e os direitos civis e políticos. Na dimensão objetiva, as normas constitucionais de direitos sociais podem assumir duas formas principais: "(1) imposições legiferantes, apontando para a obrigatoriedade de o legislador atuar positivamente, criando condições materiais e institucionais para o exercício desses direitos (...); (2) fornecimento de prestações aos cidadãos, densificadoras da dimensão subjetiva essencial destes direitos e executoras do cumprimento das imposições institucionais" ${ }^{\text {213. }}$.

Assim, a lado das imposições legiferantes, voltadas eminentemente à figura do legislador, é a instituição e a organização de um sistema de prestações que densifica

\footnotetext{
${ }^{212}$ CANotilho, José Joaquim Gomes, Direito Constitucional ... cit., pp. 463 a 506.
}

${ }^{213}$ CAnotilho, José Joaquim Gomes, Direito Constitucional ... cit., p. 466. 
juridicamente a dimensão subjetiva do direito. Ou seja, o conteúdo do direito subjetivo à educação é dado pela estrutura de fornecimento de prestações educacionais que, desde a Constituição, compromete o Estado em relação aos seus cidadãos. Este encargo, como já observado, constitui uma exigência de cidadania, vale dizer, um dever do Estado de preparar-se para que os sujeitos que com ele guardam vínculo de pertencimento de alguma sorte possam exercer os seus direitos fundamentais. Trata-se de normas constitucionais que buscam assegurar a concretização do direito, tarefa através da qual acabam por informar o conteúdo da dimensão subjetiva do direito social à educação, ou seja, identificam com maior ou menor clareza aquilo a que o indivíduo tem direito e, em contrapartida, o Estado tem dever de realizar. É o que CANOTILHO denomina de densificação jurídicoconstitucional do direito social.

No ordenamento brasileiro, em relação ao direito à educação, reconhecem-se claramente as duas sortes de previsão constitucional. De modo que é de se reconhecer que a Constituição Federal de 1988 vai muito além de uma mera previsão programática do direito à educação. Ela lhe dá um extenso detalhamento, determinando, para além da previsão genérica em seu artigo $6^{\circ}$, caput, imposições constitucionais - legiferantes - de eficácia (em especial nos artigos 211 a 214 e no artigo 60 do Ato das Disposições Transitórias) e prestações específicas a serem fornecidas pelo Estado para a concretização do direito.

É, portanto, nessa densificação constitucional do direito que se encontra o parâmetro de vinculação do Estado em relação ao direito social à educação, cuja força jurídico-constitucional compreenderia a fórmula adotada pelo Tribunal Constitucional português no Acórdão n 39/84: “(i) os direitos fundamentais sociais consagrados em normas da Constituição dispõem de vinculatividade normativo-constitucional (não são meros 'programas' ou linhas de ‘direcção política'); (ii) as normas garantidoras de direitos sociais devem servir de parâmetro de controlo judicial quando esteja em causa a apreciação da constitucionalidade de medidas legais ou regulamentares restritivas destes direitos; (iii) as normas de legislar acopladas à consagração de direitos sociais são autênticas imposições legiferantes, cujo não cumprimento poderá justificar, como já se referiu, a inconstitucionalidade por omissão, (iv) as tarefas constitucionalmente impostas ao Estado para a concretização destes direitos devem traduzir-se na edição de medidas concretas e determinadas e não em promessas vagas e abstractas; (v) a produção de medidas concretizadoras dos direitos sociais não é deixada à livre disponibilidade do 
legislador, embora este beneficie de uma ampla liberdade de conformação quer quanto às soluções normativas concretas quer quanto ao modo organizatório e ritmo de concretização" ${ }^{214}$.

Outra abordagem apresentada por CANOTILHO ${ }^{215}$, concernente especificamente à dimensão subjetiva dos direitos sociais e útil à análise feita neste trabalho, é aquela que identifica decorrerem direitos originários e direitos derivados das normas constitucionais estabelecedoras das prestações constitutivas da densificação subjetiva dos direitos sociais.

Direitos originários existem se da previsão constitucional dos direitos sociais decorrem, reciprocamente, a obrigação do Estado de prover as condições materiais (prestações) necessárias ao exercício de tais direitos e a prerrogativa do indivíduo de diretamente reclamar que lhe sejam asseguradas essas provisões.

Por sua vez, os direitos derivados a prestações decorrem da própria concretização dos direitos sociais pelo Estado, em atendimento às imposições constitucionais legiferantes e de densificação subjetiva dos direitos sociais (inclusive ultrapassando a esfera dos direitos originários a prestações - ou seja, atribuindo mais prestações do que se pode depreender inicialmente da Constituição). Isso significa afirmar que os direitos derivados são oriundos do conjunto de ações do poder público em função da efetivação dos direitos sociais. Segundo CANOTILHo, desse movimento de concretização dos direitos sociais assegurados na Constituição resultam dois direitos derivados aos cidadãos: “(1) o direito de igual acesso, obtenção e utilização de todas as instituições públicas criadas pelos poderes públicos (...); (2) direito de igual quota-parte (participação) nas prestações fornecidas por estes serviços ou instituições à comunidade"216. Esses direitos derivados contam, ambos, com a mesma conotação de direito de participação de todos os cidadãos, em igual medida, nas prestações públicas de concretização dos direitos sociais.

Os direitos derivados da concretização, por atuarem como verdadeiros definidores do conteúdo dos direitos sociais, ampliam a extensão da vinculação do poder público, assumindo a função de barreiras impeditivas de retrocesso (exercem função de guarda de flanco segundo CANOTILHO). Isso significa que é parte de sua carga normativa a garantia de que o nível de concretização alcançado não será retirado. Trata-se das conhecidas cláusulas de proibição de evolução reacionária ou de retrocesso social, reconhecidamente

\footnotetext{
${ }^{214}$ Cf. Canotilho, José Joaquim Gomes, Direito Constitucional ... cit., p. 472.

${ }^{215}$ CAnotilho, José Joaquim Gomes, Direito Constitucional ... cit., p. 467 a 469.

${ }^{216}$ Canotilho, José Joaquim Gomes, Direito Constitucional ... cit., p. 468 e 469.
} 
inerentes aos direitos fundamentais, e, em especial, aos direitos sociais ${ }^{217}$. Esse tema tem expressiva importância relativamente ao direito à educação no que se refere à progressiva extensão do acesso ao sistema de ensino, conforme se verá mais adiante.

Entende-se que esses esclarecimentos conceituais são valiosos instrumentos para análise do direito à educação conforme previsto na Constituição Federal de 1988, facilitando a exploração do conteúdo de vinculação poder público em relação à matéria. Essa verificação da trama normativa pode-se iniciar pelo esclarecimento acerca da titularidade do direito social à educação.

\subsubsection{Titularidade}

No plano constitucional, a previsão da titularidade do direito à educação extrai-se primeiramente da conjunção entre os artigos $6^{\circ}$ e 205 da Constituição Federal. O primeiro insere-se no Título II da Constituição Federal de 1988, que estabelece os direitos e garantias fundamentais do Estado brasileiro, e, evidenciando a prevalência da dimensão social do direito à educação, assim determina:

Art. $6^{\circ}$. São direito sociais a educação, a saúde, o trabalho, a moradia, o lazer, a segurança, a previdência social, a proteção à maternidade e à infância, a assistência aos desamparados, na forma desta Constituição.

O artigo 205, por sua vez, como norma base da ordem constitucional da educação, dispõe:

Art. 205. A educação, direito de todos e dever do Estado e da família, será promovida e incentivada com a colaboração da sociedade, visando ao pleno desenvolvimento da pessoa, seu preparo para o exercício da cidadania e sua qualificação para o trabalho.

No que se refere à titularidade do direito à educação, pode-se retirar dois aspectos essenciais dessas normas: (i) a topografia constitucional do artigo $6^{\circ}$ e (ii) a expressão direito de todos do artigo 205.

${ }^{217}$ CANOTILHO relata trecho do já mencionado Acórdão 39/84 do Tribunal Constitucional português em que se entendeu que "a partir do momento em que o Estado cumpre (total ou parcialmente) as tarefas constitucionalmente impostas para realizar um direito social, o respeito constitucional deste deixa de consistir (ou deixa de consistir apenas) numa obrigação positiva, para se transformar ou passar também a ser uma obrigação negativa. O Estado, que estava obrigado a actuar para dar satisfação ao direito social, passa a estar obrigado a abster-se de atentar contra a realização dada ao direito social" in CANOTILHO, José Joaquim Gomes, Direito Constitucional ... cit., p. 469. 
De fato, a localização do artigo $6^{\circ}$ no Título II da Constituição Federal evidencia que para o ordenamento brasileiro os direitos nele arrolados, dentre eles o direito à educação, constituem direitos fundamentais. De modo que o direito à educação está positivado como uma das prerrogativas imprescindíveis à convivência digna, livre e igual em sociedade, sem as quais o ser humano não atinge a própria realização nem a de seu meio $^{218}$. O caráter de indispensabilidade à personalidade humana (em oposição à personalidade moral ou jurídica) é reforçado pela própria natureza do objeto do direito: um processo formativo intelectual. Portanto, um processo formativo necessariamente humano. Desta compreensão extrai-se que não é pleonástico afirmar que o direito à educação constitui um direito fundamental do homem.

O artigo 205 retoma essas noções de essencialidade e generalidade ao esclarecer que a educação é direito de todos (os seres humanos). Essa generalidade, todavia, deve ser bem compreendida à luz da estrutura constitucional vigente. A observação que deve ser feita é semelhante àquela do diagnóstico de $\mathrm{BOBBIO}^{219}$ acerca de uma das duas tendências que caracterizaram o processo de desenvolvimento dos direitos fundamentais: a universalização e a multiplicação/proliferação. Sobre a multiplicação, BoBBIO identifica três fundamentos: (i) o aumento dos bens considerados dignos desse tipo de tutela; (ii) a extensão da titularidade de alguns direitos a outros sujeitos que não o homem (a família, as minorias, o conjunto da humanidade); e, (iii) o abandono da abordagem sobre o homem em sua abstração, como sujeito genérico, substituída pelo enfoque nas especificidades do indivíduo concreto, identificando-se direitos conforme a localização de cada um na sociedade: homens, mulheres, portadores de necessidades especiais, crianças, adolescentes etc. Desses três fatores, o aspecto da titularidade que merece maior detalhamento relaciona-se ao terceiro.

O processo de multiplicação por especificação importa essencialmente aos direitos sociais. Nesse sentido o já mencionado elemento sociológico intrínseco a essa modalidade de direitos, vale dizer, a distribuição de recursos sociais que caracteriza as prestações estatais objeto dos direitos sociais obedece à seleção de grupos determinados da sociedade a quem, em virtude de suas características de vulnerabilidade, devem ser destinados tais recursos. Assim, sobretudo no âmbito dos direitos sociais, o homem deve ser encarado em

\footnotetext{
${ }^{218}$ Cf. Silva, José Afonso da, Curso... cit., p. 178.

${ }^{219}$ BobBIO, Norberto, A Era dos Direitos, Rio de Janeio, Elsevier, 2004, pp. 82 a 87.
} 
suas especificidades e diferenças, cuja relevância faz com que o seu tratamento perante a ordem jurídica seja diferenciado.

Essas ponderações são importantes para a compreensão da expressão direito de todos, que, pelo artigo 205, caracteriza o direito à educação. Quem são todos? A Constituição Federal de 1988 e a Lei nº 9.394/1996 (Lei de Diretrizes e Bases da Educação Nacional) esclarecem.

No âmbito constitucional, o alicerce é encontrado no artigo 208, incisos I a V, da Constituição Federal de 1988. O artigo em questão, todavia, já foi objeto de alterações pela Emenda Constitucional $\mathrm{n}^{\circ}$ 14, de 1996, pela Emenda Constitucional $\mathrm{n}^{\circ}$ 53, de 2006, e, recentemente, pela Emenda Constitucional n ${ }^{\circ}$ 59, de 2009.

Originalmente, o texto constitucional determinava:

Art. 208. O dever do Estado com a educação será efetivado mediante a garantia de:

I - ensino fundamental, obrigatório e gratuito, inclusive para os que a ele não tiveram acesso na idade própria;

II - $\quad$ progressiva extensão da obrigatoriedade e gratuidade ao ensino médio;

III - atendimento educacional especializado aos portadores de deficiência, preferencialmente na rede regular de ensino;

IV - atendimento em creche e pré-escola às crianças de zero a seis anos de idade;

V - acesso aos níveis mais elevados do ensino, da pesquisa e da criação artística, segundo a capacidade de cada um;

Com o objetivo de eliminar questionamentos acerca do caráter gratuito ${ }^{220}$ do ensino fundamental de jovens e adultos que não o cursaram em idade própria e do ensino médio de modo geral, a Emenda Constitucional n 14/1996 alterou o artigo 208 para que de seus incisos I e II constasse a seguinte redação:

I - ensino fundamental, obrigatório e gratuito, assegurada, inclusive, sua oferta gratuita para todos os que a ele não tiveram acesso na idade própria;

II - $\quad$ progressiva universalização do ensino médio gratuito;

\footnotetext{
${ }^{220}$ Ressalte-se, todavia, que desde a promulgação da Constituição Federal de 1988 a gratuidade do ensino público em estabelecimentos oficiais sempre esteve enumerada como princípio da ordem educacional brasileira, relacionada em seu artigo 206. Segundo HORTA, esse caráter do direito à educação assume, inclusive, a condição de cláusula pétrea do sistema e se justifica diante da ponderação de que o principal interessado no processo educacional não é o particular/educando, como se poderia pensar, mas sim a sociedade coletivamente, que, portanto, deve sustentá-lo; cf. HoRTA, José Luiz Borges, Direito Constitucional da Educação, Belo Horizonte, Decálogo, 2007, p. 130.
} 
Por sua vez, dentre outras alterações, a Emenda Constitucional $n^{\circ}$ 53/2006 modificou a redação do inciso IV do artigo 208, do qual passou a constar o seguinte:

IV - $\quad$ educação infantil, em creche e pré-escola, às crianças até 5 (cinco) anos de idade;

A partir do panorama constitucional, a Lei $\mathrm{n}^{\circ}$ 9.394/1996, ao organizar a educação básica no Brasil, fazia e ainda faz os esclarecimentos normativos complementares, com o que auxilia na identificação dos grupos específicos semanticamente contidos na expressão direito de todos.

Para esse fim, importam os seguintes dispositivos do mencionado diploma: artigo $4^{\circ}$, inciso IV, artigo 29, artigo 30, artigo 32, caput, artigo 35, caput $^{221}$. Em linhas gerais, extrai-se dessas normas que a educação básica no Brasil compreende, primeiramente, a educação infantil (artigos $4^{\circ}$, inciso IV, 29 e 30) para crianças entre zero e seis anos de idade, a serem atendidas em creches (crianças de zero a três anos) ou pré-escolas (crianças de quatro a seis anos de idade).

Percebe-se facilmente uma incongruência existente entre a nova redação do inciso IV do artigo 208 da Constituição Federal e o disposto no artigo $4^{\circ}$, inciso IV, no artigo 29 e no artigo 30, inciso II, da Lei $n^{\circ}$ 9.304/1996, no que diz respeito à idade limite da educação infantil: cinco anos no texto constitucional e seis anos na lei ordinária. Vale anotar que, originalmente, a Lei $\mathrm{n}^{\mathrm{o}} 11.274$ de 06 de fevereiro de 2006 alterava os artigos 29 e 30, inciso II, para estabelecer o teto de cinco anos de idade para a educação infantil. Todavia, sendo esse diploma anterior à Emenda Constitucional $\mathrm{n}^{\circ}$ 53, promulgada em 19 de dezembro de 2006, tais dispositivos foram vetados pelo presidente da República sob o argumento de possuírem vício de inconstitucionalidade material (já que o teto estabelecido pela Constituição Federal era, então, de 6 anos). Ademais, o legislador ordinário de 2006 esquecia-se de alterar o artigo $4^{\circ}$, inciso IV, da própria Lei n ${ }^{\circ}$ 9.394/1996, dispositivo responsável pela definição dos direitos e deveres relativos à educação, pelo que, sem o

\footnotetext{
${ }^{221}$ Lei $\mathrm{n}^{\mathrm{o}}$ 9.394/1996:

Art. $4^{\circ}$. O dever do Estado com educação escolar pública será efetivado mediante a garantia de: (...) IV - atendimento gratuito em creches e pré-escolas às crianças de zero a seis anos de idade; (...)

Art. 29. A educação infantil, primeira etapa da educação básica, tem como finalidade o desenvolvimento integral da criança até seis anos de idade, em seus aspectos físico, psicológico, intelectual e social, complementando a ação da família e da comunidade.

Art. 30. A educação infantil será oferecida em:

I - creches, ou entidades equivalentes, para crianças de até três anos de idade;

II - pré-escolas, para as crianças de quatro a seis anos de idade. (...)

Art. 32. O ensino fundamental obrigatório, com duração de 9 (nove) anos, gratuito na escola pública, iniciando-se aos 6 (seis) anos de idade, terá por objetivo a formação básica do cidadão, mediante: (...)

Art. 35. O ensino médio, etapa final da educação básica, com duração mínima de três anos, terá como finalidades: (...).
} 
veto, o diploma restaria contraditório em sua essência. Atualmente, enfim, após a edição da Emenda Constitucional $n^{\circ} 53$, é imperativa uma interpretação conforme à Constituição dos $\operatorname{artigos} 4^{\circ}$, inciso IV, 29 e $30^{222}$, verificando-se que o período de educação infantil estendese dos zero aos cinco anos de idade.

No segundo patamar da educação básica está o ensino fundamental que, conforme a redação do artigo 32 da Lei no 9.394/1996 (com alteração da Lei no 11.274/2006), deve iniciar-se aos seis anos de idade e ter duração de nove anos. Em seguida, portanto iniciando-se aos quinze anos de idade, vem o ensino médio, cuja duração mínima, consoante o previsto no artigo 35, caput, da Lei n 9.394/1996, será de três anos.

Esses dados permitem identificar, então, três patamares de titularidade direta do direito à educação, correspondendo a cada um deles uma modalidade de prestação estatal como elemento de satisfação do direito:

- crianças de zero a cinco anos - atendimento por meio de educação infantil em creche ou pré-escola;

- crianças a partir do ano em que completam seis anos até o fim dos 9 anos de ensino fundamental (se cumpridos regularmente, até o ano em que o adolescente completa 14 ou 15 anos) - atendimento em instituições de ensino fundamental;

- $\quad$ adolescentes que terminam o ensino fundamental - atendimento por mais três anos no mínimo (se cumpridos regularmente, do ano em que completam quinze anos até o ano em que completam 17 ou 18 anos);

A esses titulares diretos (sujeitos/objeto do processo educativo) a Constituição Federal do 1988 acrescentava, no inciso I do artigo 208, tanto no texto original como na redação conferida pela Emenda Constitucional n ${ }^{\circ}$ 14/1996, aqueles que não tiveram acesso ao ensino fundamental na idade própria, identificando mais um grupo de titularidade direta do direito à educação.

Entretanto, esse quadro foi alterado com a promulgação da Emenda Constitucional $n^{\circ} 59 / 2009$, que alterou o inciso I do artigo 208 para que dele constasse a seguinte redação:

Art. 208. O dever do Estado com a educação será efetivado mediante a garantia de:

\footnotetext{
${ }^{222}$ O Projeto de Lei iniciado no Senado n ${ }^{\circ} 414$ de 2008, de autoria do Senador Flávio Arns, objetiva fazer as alterações necessárias aos dispositivos em questão para eliminar a contradição com o texto constitucional. Além dos dispositivos referidos, o projeto também sugere alteração nos artigos $6^{\circ}, 32,58, \S 3^{\circ}$ e 87 .
} 
I - educação básica obrigatória e gratuita dos 4 (quatro) aos 17 (dezessete) anos de idade, assegurada inclusive sua oferta gratuita para todos os que a ela não tiveram acesso na idade própria;

Um elemento do novo texto deve ser destacado: a conexão constitucional do conceito de educação básica a uma faixa etária correspondente. Foi, portanto, pelo menos parcialmente constitucionalizada a organização que faz a Lei $n^{\circ}$ 9.394/1996, à medida que a Constituição agora define, além do teto da educação infantil aos cinco anos, também o teto da educação básica aos dezessete anos. Desse modo, restaria à conformação legislativa apenas definir nesse intervalo quanto se deve cumprir no ensino fundamental e quanto no ensino médio (atualmente nove e três anos, respectivamente).

Importa notar, em resumo, que a segunda parte do inciso em questão ampliou a titularidade daqueles que não tiveram acesso à educação na idade própria. Se antes seu direito estava assegurado estritamente quanto ao ensino fundamental, agora passou a abranger toda a educação básica.

A verificação dos grupos de titulares diretos do direito à educação, aos quais o Estado obriga-se, desde a Constituição Federal do 1988, a prover prestações satisfativas específicas requer, ainda, a alusão às pessoas com deficiência. Atendidos os requisitos etários, estes constituem outro conjunto de titulares diretos do direito à educação a quem o poder público deve prestar atendimento especializado, ainda que de modo integrado à rede regular de ensino (artigo 208, inciso III). Sobre o tema, é necessária a referência à Convenção Internacional sobre os Direitos das Pessoas com Deficiência ${ }^{223}$, de 30 de março de 2007, aprovada no Congresso Nacional através do procedimento de aprovação das Emendas Constitucionais (conforme o $§ 3^{\circ}$ do artigo $5^{\circ}$ da Constituição Federal).

Consoante o artigo 24, parágrafo 2', alíneas 'a' e 'b', da mencionada Convenção, cuja força é, portanto, equiparada à de Emenda Constitucional, o Estado brasileiro compromete-se a assegurar que as pessoas com deficiência "não sejam excluídas do sistema educacional geral sob alegação de deficiência e que as crianças com deficiência não seja excluídas do ensino primário gratuito e compulsório ou do ensino secundário, sob alegação de deficiência"; e que "possam ter acesso ao ensino primário inclusivo, de qualidade e gratuito, e ao ensino secundário, em igualdade de condições com as demais pessoas na comunidade em que vivem".

${ }^{223}$ Decreto ${ }^{\circ} 6.949$, de 25 de agosto de 2009. 
Teria havido, assim, uma ampliação do texto constitucional no que respeita às pessoas com deficiência relativa à identificação da prestação pertinente a esse grupo. Entende-se que, em atenção à Convenção Internacional sobre os Direitos das Pessoas com Deficiência, não há mais espaço para a expressão constitucional preferencialmente na rede regular de ensino, contida no inciso III do artigo 208 da Constituição Federal de 1988. Isso significa que, atualmente, às pessoas com deficiência titulares do direito à educação corresponde necessária e exclusivamente a prestação educacional pela via regular, em instituições de ensino comuns e em igualdade de condições com as demais pessoas. Estruturalmente, contudo, segundo o mesmo inciso III, a forma de tal atendimento deve estar especialmente preparada às necessidades particulares que a condição das pessoas com deficiência impõe.

Observa-se, então, ser necessário acrescentar mais dois tópicos ao painel de titularidade direta supra indicado:

- jovens e adultos que não tiveram acesso à educação básica na idade própria - atendimento em estabelecimentos de ensino fundamental ou médio, conforme o nível educacional;

- pessoas com deficiência em idade escolar - atendimento em estabelecimentos da rede regular de educação básica.

Há um temperamento estrutural sobre o direito à educação que, por referir-se à questão da titularidade, deve ser objeto de nota neste subitem. Trata-se do supra transcrito inciso V do artigo 208 da Constituição Federal de 1988. Este dispositivo estabelece que o acesso aos níveis mais elevados do ensino, da pesquisa e da criação artística dar-se-á mediante a capacidade individual. Do ponto de vista normativo isso indica que é da estrutura do direito à educação que a progressão no processo de ensino dê-se aliada à meritocracia individual de seus sujeitos passivos ${ }^{224}$. Vale dizer, no que tange à promoção aos estágios seguintes de prestação educativa, o direito à educação integra-se mediante o preenchimento de requisitos de mérito pessoal $^{225}$. Deve restar claro que esta é uma

\footnotetext{
${ }^{224}$ Por expressa previsão do artigo 31 da Lei n ${ }^{\circ}$ 9.394/1996, na educação infantil as avaliações não possuem o objetivo de promoção, nem podem servir de critério de acesso ao ensino fundamental.

${ }^{225}$ Todavia, não se pode permitir que os mecanismos de promoção desnaturem-se em obstáculos ao acesso à educação. Nesse sentido, PONTES DE MIRANDA comentou: “[a] promoção é essencial aos cursos. Não nos parece que a selecção seja necessária á frequencia. Somos pela livre entrada em todas as escolas, pela educação ao alcance de todos. Sómente onde se quer estabelecer a gradação póde valer como principio a exigencia de entrada e de passagem" in PONTES DE MIRANDA, Francisco Cavalcanti, Direito á Educação, Rio de Janeiro, Alba, 1933, pp. 94 e 95.
} 
exigência da Constituição Federal de 1988. De modo que qualquer iniciativa do poder público no sentido de progredir os titulares do direito à educação no processo educacional desligada de algum critério de mérito individual padecerá de inconstitucionalidade.

Esta ressalva tem grande relevância no que diz respeito ao ensino superior, dado que a Lei $n^{\circ}$ 9.394/1996 concede às instituições de ensino superior a atribuição de fixar requisitos e exigências de acesso para os cursos seqüenciais, de pós-graduação e de extensão, e de organizar processo seletivo para o acesso aos cursos de graduação. Especificamente neste âmbito, vale anotar que a Lei $\mathrm{n}^{\circ} 12.089$, de 11 de novembro de 2009, definiu nacionalmente uma limitação à prestação pública de curso de graduação a uma por indivíduo (titular), proibindo que uma pessoa curse, simultaneamente, dois cursos de graduação em instituições públicas de ensino superior ${ }^{226}$.

A expressão titularidade direta utilizada até este momento indica que se reconhece, adicionalmente, uma titularidade indireta do direito à educação. Enquanto a primeira refere-se aos sujeitos submetidos à prestação educacional propriamente dita (de que são credores, portanto), a segunda consiste numa decorrência das relações familiares e da dimensão coletiva do direito à educação, enquanto interesse dos pais e da sociedade (ou do próprio Estado), respectivamente.

Viu-se que a educação consubstancia-se num direito atribuído textualmente a todos (artigo 205 da Constituição Federal), mas que, quando dissecado em função das prestações públicas que envolve, especializa-se num direito de determinados grupos. Anotou-se, anteriormente, que essa é, em verdade, uma característica da estrutura dos direitos fundamentais sociais: são direitos de grupos sociais, à medida que só os possuem aqueles indivíduos que pertençam a tais grupos sociais, sendo que estes, por sua vez, são eleitos mediante uma investigação sociológica própria, que identifique necessidades específicas,

\footnotetext{
${ }^{226}$ Lei $^{\mathrm{o}}$ 12.089/2009:

Art. $2^{\circ}$. É proibido uma mesma pessoa ocupar, na condição de estudante, simultaneamente, no curso de graduação, 2 (duas) vagas, no mesmo curso ou em cursos diferentes em uma ou mais de uma instituição pública de ensino superior em todo o território nacional.

Art. $3^{\circ}$. A instituição pública de ensino superior que constatar que um dos seus alunos ocupa uma outra vaga na mesma ou em outra instituição deverá comunicar-lhe que terá de optar por uma das vagas no prazo de 5 (cinco) dias úteis, contado do primeiro dia útil posterior à comunicação.

$\S 1^{\text {o }}$ Se o aluno não comparecer no prazo assinalado no caput deste artigo ou não optar por uma das vagas, a instituição pública de ensino superior providenciará o cancelamento:

I - da matrícula mais antiga, na hipótese de a duplicidade ocorrer em instituições diferentes;

II - da matrícula mais recente, na hipótese de a duplicidade ocorrer na mesma instituição.

$\S 2^{\underline{o}}$ Concomitantemente ao cancelamento da matrícula na forma do disposto no $\S 1^{\underline{0}}$ deste artigo, será decretada a nulidade dos créditos adquiridos no curso cuja matrícula foi cancelada.
} 
relações sociais pertinentes etc. ${ }^{227}$. Nesse sentido, trata-se de direito cuja titularidade direta recai não apenas sobre o indivíduo em si, mas também sobre o grupo a que pertence, que DUARTE denomina de grupo vulnerável ${ }^{228}$.

Ocorre que, quanto ao direito à educação, os efeitos de sua satisfação espraiam-se para além das esferas particulares dos indivíduos e grupos a quem são devidas, diretamente, as prestações educacionais. A concretização do direito à educação incide, também, sobre os interesses da família e da sociedade, fazendo destas titulares do direito de verem satisfeitas as pretensões dos primeiros. Identificam-se, assim, pelo menos duas outras esferas de titularidade (ainda que indireta). Entretanto, há quem registre outros âmbitos. Por exemplo, RANIERI entende que a Constituição Federal de 1988 estende a titularidade do direito à educação também às gerações futuras, além da família, da sociedade, do Estado e, evidentemente, do próprio indivíduo ${ }^{229}$. MONTEIRO, por sua vez, recorda das eventuais pretensões das religiões, historicamente as grandes interessadas na educação $^{230}$.

Vale registrar que constatações nesse sentido não são novas, antecedendo à própria formulação do direito à educação em direito público subjetivo, tal qual se tem na atualidade. De fato, exemplificativamente, basta a lembrança de PimEnTA BuEno que, comentando a Constituição Imperial de 1984, afirmou: “[a] instrução primária é uma necessidade, não desta ou daquela classe, sim de todas, ou de todos os indivíduos; o operário, o artífice mais humilde, o pobre precisa saber ler, escrever, e pelos menos as primeiras operações aritméticas (...). É pois uma necessidade geral, e consequentemente uma dívida da sociedade, pois que para as necessidades gerais é que se criam, e recebem as contribuições públicas; acresce ainda que a satisfação desta obrigação reverte em proveito

\footnotetext{
227 ABRAMOVICH, Víctor e CoURTIS, Christian, El Umbral de... cit., pp. 15 e 16.

${ }^{22}$ Nas palavras da autora, sobre o direito ao ensino obrigatório e gratuito, "como estamos diante de um direito social, seu objeto não é, simplesmente, uma prestação individualizada, mas sim a realização de políticas públicas, sendo que sua titularidade se estende aos grupos vulneráveis" in DUARTE, Clarice Seixas, Direito Público Subjetivo e Políticas Educacionais, in São Paulo em Perspectiva, v. 18(2), 2004, p. 115.

${ }^{229}$ Nas palavras da autora: "[d]efinidos os fundamentos axiológicos e teleológicos do direito à educação, a Constituição Federal cerca-o de garantias, estende a sua titularidade da pessoa humana à sociedade, ao Estado, às gerações futuras e, de forma correlata, insere o Estado, a sociedade, a família e o próprio indivíduo no pólo passivo do direito" in RANIERI, Nina Beatriz Stocco, O Estado Democrático... cit., pp. 315 e 316.

${ }^{230}$ Nas palavras do autor: "a educação é objecto de várias pretensões de direito: dos pais, desde sempre, porque os filhos são seus; dos Estados, sobretudo desde o aparecimento do Estado-nação, porque os cidadãos são também seus e, em todo caso, porque na educação está em jogo o Bem Comum; sem esquecer os interesses das religiões, ao longo dos tempos; e ainda (...) o interesse dos próprios educandos, que começam por estar na mais absoluta dependência dos adultos" in MonTEIRo, Agostinho dos Reis, O Pão do Direito à Educação, in Educação e Sociedade, v. 24, n. 84, 2003, p. 768.
} 
da própria associação, que por este meio consegue tornar mais úteis e moralizados os seus membros em geral" 231 .

No âmbito da ordem positiva atual, essa titularidade indireta é evidenciada, sobretudo, na previsão instrumental de mecanismos de tutela coletiva do direito à educação, tais como a ação civil pública e o mandado de segurança coletivo. Maior importância, no mesmo sentido, reside no fortalecimento das funções do Ministério Público na defesa dos interesses sociais e individuais indisponíveis de maneira geral $^{232}$, promovido pela ordem constitucional de 1988. Especificamente quanto à educação, à previsão genérica da função dessa instituição para a tutela dos interesses difusos e coletivos, mediante o inquérito civil e a ação pública, contida no inciso III do artigo $129^{233}$ da Constituição Federal de 1988, acrescenta-se a norma do artigo $208^{234}$ e seus incisos da Lei $\mathrm{n}^{\circ}$ 8.069, de 13 de julho de 1990 (Estatuto da Criança e do Adolescente), especificamente voltada à realização do direito à educação de crianças e adolescentes mediante ações cíveis propostas pelo Ministério Público, pela União, pelos Estados, pelos Municípios, pelo Distrito Federal, e por associações civis legitimadas. O tema da tutela coletiva do direito à educação será retomado mais adiante.

Por fim, no que diz respeito à titularidade indireta da família, ou seja, dos pais ou responsáveis, existe, evidentemente, a representação em juízo geral, decorrente do poder familiar (artigo $8^{\circ}$ do Código de Processo Civil e artigo 1.630 do Código Civil). Todavia, dentro do raciocínio apresentado até este ponto, exemplo maior de que também os pais são

\footnotetext{
${ }^{231}$ Pimenta Bueno, José Antonio, Direito público brasileiro e análise da Constituição do Império, Rio de Janeiro, Ministério da Justiça e Negócios Interiores, 1958, p. 430.

${ }^{232}$ Assim estabelece o artigo 127 da Constituição Federal: Art. 127. O Ministério Público é instituição permanente, essencial à função jurisdicional do Estado, incumbindo-lhe a defesa da ordem jurídica, do regime democrático e dos interesses sociais e individuais indisponíveis.

${ }^{233}$ Art. 129. São funções institucionais do Ministério Público: (...) III - promover o inquérito civil e a ação civil pública, para a proteção do patrimônio público e social, do meio ambiente e de outros interesses difusos e coletivos.

${ }^{234}$ Art. 208. Regem-se pelas disposições desta Lei as ações de responsabilidade por ofensa aos direitos assegurados à criança e ao adolescente, referentes ao não oferecimento ou oferta irregular:

I - do ensino obrigatório;

II - de atendimento educacional especializado aos portadores de deficiência;

III - de atendimento em creche e pré-escola às crianças de zero a seis anos de idade;

IV - de ensino noturno regular, adequado às condições do educando;

V - de programas suplementares de oferta de material didático-escolar, transporte e assistência à saúde do educando do ensino fundamental;

VI - de serviço de assistência social visando à proteção à família, à maternidade, à infância e à adolescência, bem como ao amparo às crianças e adolescentes que dele necessitem;

VII - de acesso às ações e serviços de saúde;

VIII - de escolarização e profissionalização dos adolescentes privados de liberdade.

IX - de ações, serviços e programas de orientação, apoio e promoção social de famílias e destinados ao pleno exercício do direito à convivência familiar por crianças e adolescentes.
} 
titulares é oferecido pelo inciso XXV do artigo $7^{\circ}$ da Constituição Federal, que assim estabelece:

Art. $7^{\circ}$. São direitos dos trabalhadores urbanos e rurais, além de outros que visem à melhoria de sua condição social:

(...)

XXV - assistência gratuita aos filhos e dependentes desde o nascimento até 5 (cinco) anos de idade em creches e pré-escolas;

Compreendida a questão da titularidade, a determinação precisa da estrutura de vinculação jurídica do direito social à educação depende também da verificação de seu sujeito passivo (a quem é oponível) e de seu objeto.

\subsubsection{Oponibilidade}

Ao se prosseguir na análise do parâmetro de vinculação gerado pelo direito social à educação é importante retomar-se, desde logo, que se está avaliando o ensino formal, isto é, o processo educativo ministrado por instituições escolares, diretamente pelo Estado ou, pelo menos, sob sua autorização e fiscalização. Essa clareza impõe-se diante do fato de que a primeira norma constitucional de sujeição ao dever de prover a educação, o já transcrito artigo 205 da Constituição Federal de 1988, afirma ser o direito a ela oponível ao Estado e à família. Na mesma linha segue o artigo $227^{235}$ da Constituição Federal, que à família e ao Estado acrescenta a sociedade, genericamente considerada, entre os sujeitos passivos (devedores) do direito social à educação das crianças e adolescentes, cujo atendimento, estabelece a Constituição no mesmo artigo, possui prioridade absoluta.

Neste assunto, é importante esclarecer que no concernente à sociedade, genericamente, e à família, o dever de prover a educação manifesta-se com mais evidência e volume normativo nas normas relativas ao direito de infância e aos deveres inerentes ao exercício do poder familiar. Portanto relaciona-se mais claramente com a educação informal do que com a formal. Vale dizer, o maior detalhamento presente no ordenamento

${ }^{235}$ Art. 227. É dever da família, da sociedade e do Estado assegurar à criança e ao adolescente, com absoluta prioridade, o direito à vida, à saúde, à alimentação, à educação, ao lazer, à profissionalização, à cultura, à dignidade, ao respeito, à liberdade e à convivência familiar e comunitária, além de colocá-los a salvo de toda forma de negligência, discriminação, exploração, violência, crueldade e opressão. 
acerca da educação escolar, inclusive com vasto tratamento constitucional, opõe-se ao Estado, e não à família ou ao corpo social geral.

A doutrina da proteção integral da criança e do adolescente, fundamentada no artigo 227 da Constituição Federal de 1988, reconhece neles indivíduos em condição peculiar de desenvolvimento pessoal, o que os submete a uma vulnerabilidade diferenciada e os torna merecedores, com prioridade absoluta, de proteção especial de sua personalidade. Tal proteção deve assentar-se especialmente nos direitos de crianças e adolescentes à liberdade, à dignidade e ao respeito, conforme definidos nos artigos 16, 17 e 18 da Lei $n^{\circ}$ 8.069/1990, respectivamente. Isso redundou na necessidade de criação de um sistema especial de garantias, cuja diretriz primordial é a prevenção de possíveis violações ou ameaças de lesão aos direitos fundamentais de crianças e adolescentes.

Levado a efeito pelo Estatuto da Criança e do Adolescente, esse sistema é integrado pelo juízo especializado da infância e da juventude (artigos 146 a 151 da Lei no 8.069/1990); pelos Conselhos Municipais, Estaduais e Nacional de Direitos (artigo 88, inciso II, da Lei $\mathrm{n}^{\circ}$ 8.069/1990); pelos Conselhos Tutelares (órgãos de atuação e composição local - artigos 131 a 140 da Lei $n^{\circ}$ 8.069/1990); pelas entidades de atendimentos governamentais e não governamentais (artigos 90 a 97 da Lei no 8.069/1990); pelo Ministério Público (artigos 200 a 205 da Lei n 8.069/1990); além da previsão de funções reservadas à advocacia e à Defensoria Pública.

A referida diretriz de prevenção está especificamente regulada entre os artigos 70 e 85 da Lei $\mathrm{n}^{\circ}$ 8.069/1990. Desses dispositivos destacam-se os artigos 74 a 80, que regulam o acesso de crianças e adolescentes à informação, à cultura, ao lazer, aos esportes, às diversões e aos espetáculos. A lógica de regência dessas normas, em resumo, é a de que o acesso a esses fatores, que também integram a aprendizagem geral da pessoa, deve ser garantido na proporção da capacidade de entendimento de crianças e jovens, o que justifica o estabelecimento, pelo poder público ${ }^{236}$, de classificações em função da faixa etária (artigo 75). Essas restrições, inclusive, contam com fundamento constitucional expresso (artigo 220, $\S 3^{\circ}$, inciso II, combinado com artigo 221, inciso IV).

Essa complexa estrutura normativa, aqui apenas superficialmente mencionada por não consistir o tema desta Dissertação, é exemplo do dever da sociedade, genericamente considerada, em relação à educação informal. Ou seja, esse dever corresponde a uma

${ }^{236}$ Realizado pelo Ministério da Justiça, conforme a Portaria $n^{\circ} 733 / 1990$, e normas administrativas subseqüentes. 
obrigação de respeito à condição peculiar de desenvolvimento pessoal em que se encontram crianças e jovens.

No âmbito da família o dever relativo à educação informal está contido nos artigos 1.630 a 1.639 do Código Civil de 2002 e artigo 22 da Lei $\mathrm{n}^{\circ}$ 8.069/1990, que regulam o exercício do poder familiar e os ônus a ele inerentes. Assim é que a lei determina aos pais ou responsáveis, em relação à pessoa dos filhos menores, dirigir sua educação e criação, têlos em sua companhia e guarda, e exigir que lhes prestem obediência, respeito e os serviços próprios de sua idade e condição (respectivamente incisos I, II e VII do artigo 1.634 do Código Civil de 2002) ${ }^{237}$.

Percebe-se que existe um semelhante caráter genérico e abrangente na formação da personalidade protegida pelo Estatuto da Criança e do Adolescente e na educação enquanto decorrência do poder familiar. Por isso a afirmativa de que essas disciplinas se referem com mais força à educação informal do que à formal (educação escolar), ainda que esta pertença ao conjunto (logo, mais amplo) dos deveres decorrentes do poder familiar.

Os deveres relacionados à educação informal possuem estrutura distinta daqueles concernentes ao direito social à educação, justamente em função do caráter genérico que a distingue. A definição de específicas prestações educacionais (como são as que integram a educação básica, por exemplo) de responsabilidade exclusiva do Estado (mediante fornecimento direto ou sob sua autorização e controle), aliada ao dever do poder público de se organizar para atendê-las, não ocorre na educação informal do mesmo modo que na educação formal.

Em relação ao poder público, a educação informal envolve outra organização e outras prestações, caracterizadas, como mencionado, antes pela natureza protetiva contra abusos do que por ações formativas propriamente ditas. Nesse âmbito, diferentemente, a família e a sociedade têm o conteúdo de sua situação de devedoras muito mais claramente definido pelo direito positivo (no Estatuto da Criança e do Adolescente, no Código Civil etc.), do que contam relativamente à educação formal.

\footnotetext{
${ }^{237}$ Sobre o tema, leciona RoDRIGUES: “[d]irigir-lhes a criação e educação. Aqui se trata do zelo material e moral para que o filho fisicamente sobreviva e por meio da educação forme seu espírito e seu caráter. Esse é o dever principal que incumbe aos pais, pois quem põe filhos no mundo deve provê-los com os elementos materiais para a sobrevivência, bem como fornecer-lhes educação de acordo com seus recursos, capaz de propiciar ao filho, quando adulto, um meio de ganhar a vida e de ser elemento útil à sociedade". E mais adiante: "[e]xigir que lhes prestem obediência, respeito e os serviços próprios de sua idade e condição. Dentre as prerrogativas dos pais, acima aludidas, o direito de exigir obediência e respeito é parte da educação e, para alcançar esses fins, pode o genitor castigar o filho, contanto que o faça moderadamente" in Rodrigues, Silvio, Direito Civil: direito de família, São Paulo, Saraiva, 2004, pp. 360-361 e 363.
} 
Ressalte-se mais uma vez: o direito social à educação previsto nos artigos 205 a 214 da Constituição Federal de 1988 e regulado por extensa legislação infraconstitucional ${ }^{238}$ refere-se à educação formal. Nesse âmbito, o âmbito da educação escolar, o devedor por excelência é o Estado e as previsões relativas à família e à sociedade são em menor número e menos contundentes. Elas contam, na realidade, com uma natureza de complementaridade e/ou viabilização em relação à atuação do poder público no atendimento do direito social à educação.

O próprio poder familiar abrange, evidentemente, também a obrigação em relação à educação escolar. À previsão de caráter amplo do mencionado artigo 1.634 do Código Civil de 2002 soma-se a disposição específica do artigo 55 da Lei no 8.069/1990, que impõe aos pais ou responsável o dever de matricular filhos ou pupilos na rede regular de ensino $^{239}$. Neste aspecto do exercício do poder familiar, inclusive, a lei atribui aos dirigentes dos estabelecimentos de ensino fundamental o dever de fiscalizar o desempenho das obrigações parentais, informando eventuais violações ao Conselho Tutelar (artigo 56 da Lei $\left.n^{\circ} 8.069 / 1990\right)^{240}$.

O descumprimento do dever de prover a educação escolar pode levar à suspensão do poder familiar, ou mesmo à sua perda, se reiterado, na forma dos artigos 1.637 e 1.638 do Código Civil de 2002, e do artigo 24 da Lei nº 8.069/1990. Há, ainda, tutela penal nesse sentido: o crime de abandono intelectual, tipificado pelo artigo 246 do Código Penal de $1940^{241}$.

Essas previsões reforçam a tese de que para a concretização do direito à educação não é suficiente sua disponibilização e incentivo por parte do Estado. Cabe aos pais, em complementação, o agir prático (no plano físico), no exercício do poder familiar, que torne possível essa efetivação ${ }^{242}$.

Sobre o tema da criminalização, todavia, duas ressalvas devem ser consideradas.

\footnotetext{
${ }^{238}$ Lei $^{\text {o }} 8.069 / 1990$, Lei n ${ }^{\circ} 9.394 / 1996$, Lei no $10.172 / 2001$.

${ }^{239}$ Lei $\mathrm{n}^{\circ}$ 8.069/1990: (...) Art. 55. Os pais ou responsável têm dever de matricular seus filhos ou pupilos na rede regular de ensino.

${ }^{240}$ Lei $\mathrm{n}^{\circ}$ 8.069/1990: (...) Art. 56. Os dirigentes de estabelecimentos de ensino fundamental comunicarão ao Conselho Tutelar os casos de:

I - maus tratos envolvendo seus alunos;

II - reiteração de faltas injustificadas e de evasão escolar, esgotados os recursos escolares;

III - elevados níveis de repetência.

${ }^{241}$ Código Penal: (...) Art. 246. Deixar, sem justa causa, de prover à instrução primária de filho em idade escolar: Pena - detenção, de 15 (quinze) dias a 1 (um) mês, ou multa.

${ }^{242}$ Cf. GReCO, Rogério, Curso de Direito Penal: Parte Especial: Volume III, Niterói, Impetus, 2007, p. 684.
} 
Primeiramente, cumpre lembrar que o tipo penal em questão refere-se ao não provimento da educação primária, sem justa causa. Esta elementar do tipo, justa causa, abre ao juiz a possibilidade de verificação das circunstâncias do caso concreto para considerar a conduta dos pais típica ou atípica. Assim é que, conforme exemplifica GrECO, "os pais que, por se encontrarem em situação de absoluta pobreza, não tendo como levar seu filho à escola, que se localiza muito distante de sua casa, ou ainda pelo fato de não existir o próprio estabelecimento de ensino" ${ }^{243}$, não realizarem a matrícula ${ }^{244}$ de seus filhos na rede de ensino não cometerão o crime do artigo 246 do Código Penal de 1940, por atipicidade.

A segunda observação a ser feita refere-se à expressão educação primária. Esta expressão, característica da época em que foi editado o dispositivo, já não consta do ordenamento posto como nível ou modalidade formal de ensino. Na doutrina, o enunciado foi reiteradamente compreendido como o período relativo ao ensino fundamental ${ }^{245}$ que, desde a Lei $\mathrm{n}^{\circ} 11.114$ de 2005, deve iniciar-se aos seis anos de idade (estendendo-se por nove anos atualmente). Para essa conclusão, conforme salienta GRECO, o artigo 246 do Código Penal de 1940 é entendido como norma penal em branco, cuja complementação é promovida pela Lei ${ }^{\circ} 9.394 / 1996$, especificamente nos artigos $6^{\circ}$ e 32 . Ocorre que esses dispositivos, até a Emenda Constitucional $n^{\circ}$ 59/2009, eram responsáveis por atribuir conteúdo semântico à norma constitucional que (apenas) previa a obrigatoriedade do ensino fundamental (artigo 208, inciso I).

Mas a recente alteração constitucional fez com que a própria Constituição Federal de 1988 passasse a definir parâmetros claros de início e fim da obrigatoriedade da educação (dos quatro aos dezessete anos), estendendo-a a toda a educação básica

\footnotetext{
${ }^{243}$ GRECO, Rogério, Curso de ... cit., p. 684.

${ }^{244} \mathrm{Na}$ jurisprudência, verifica-se a materialidade do crime não apenas pela ausência de matrícula, como também pela incapacidade de manutenção real do filho no processo educativo. Nesse sentido: "[a]bandono intelectual (art. 246 do CP) - Réu, reincidente, condenado a dezesseis dias de detenção, em regime inicial aberto, substituídos por prestação de serviços à comunidade - Apelo do réu, insistindo na absolvição improvimento - Materialidade do delito comprovada pelos documentos que atestam as sucessivas faltas do adolescente às aulas e pelas próprias declarações do menos, que afirmou haver sido reprovado na $8^{\mathrm{a}}$ série, justamente em razão daquelas faltas - Dolo do réu evidenciado pelo seu descaso com a situação, embora tempestivamente alertado pelo Conselho tutelar - Descaso ainda revelado pela prova oral colhida e até pelas declarações prestadas pelo adolescente na fase policial, pois ele afirmou que, quando seus pais o colocavam de castigo, acabava se convencendo a ir à escola - Sentença mantida pelos próprios fundamentos" (sem realce no original) in Estado de SÃo Paulo, Poder Judiciário, ColÉGio ReCursal dos Juizados EsPeciais Cíveis e Criminais do Estado de SÃo PAUlo, Apelação n 5976, Juiz Relator Elias Junior de Aguiar Bezerra, julgamento em 16.10.2008.

${ }^{245}$ Nesse sentido, Jesus, Damásio E. de, Código Penal Anotado, São Paulo, Saraiva, 2001, p. 789; Delmanto, Celso et al., Código Penal Comentado, Rio de Janeiro, 2002, p. 516; e, Greco, Rogério, Curso de ... cit., pp. 684 e 685.
} 
(excetuados os primeiros anos da educação infantil). Assim, deve-se questionar se teria estendido também a amplitude do tipo penal.

Certamente, a questão será controvertida e aqui não se pretende chegar a alguma conclusão. No entanto, apenas relembre-se que em mais de uma passagem a Constituição Federal de 1988 usa a expressão dever da família ou dos pais (artigos 205, 227 e $229^{246}$ ). Além disso, foi clara a vontade do constituinte reformador em tornar a educação básica integralmente obrigatória, aí incluído o ensino médio.

Ora, é um mandado de eficácia que em resposta a toda obrigação o ordenamento preveja as sanções suficientes. Se tutelou com a ameaça penal o ensino fundamental obrigatório, parece natural que atue da mesma forma agora em relação à educação básica obrigatória. É verdade que, historicamente, a instrução primária tenha correspondido ao ensino fundamental. Mas é verdade, também, que, junto com a sociedade, evoluíram as necessidades educacionais brasileiras. Prova disso é a própria alteração do texto constitucional realizada pela Emenda Constitucional n ${ }^{\circ}$ 59/2009.

Outro exemplo da mesma lógica de imposição aos pais de medidas concretas que permitam ao Estado concretizar o direito à educação de crianças e adolescente é encontrado na legislação previdenciária. Trata-se do artigo 67 da Lei $n^{\circ} 8.213$, de 24 de julho de 1991, a lei que regula os benefícios da previdência social. O dispositivo em questão, regulamentado pelo artigo 84 do Decreto Federal n 3.048, de 6 de maio de 1999 determina que para a concessão do benefício previdenciário do salário-família (ao qual fazem jus apenas o empregado e o trabalhador avulso de baixa renda), o segurado deverá fornecer comprovação semestral de freqüência à escola do filho ou equiparado, a partir dos sete anos de idade ${ }^{247}$.

Portanto, percebe-se que em diversas passagens do ordenamento determina-se à família a adoção de medidas que se acrescentarão à atividade do poder público no sentido de efetivar o direito social à educação. Prevalece, no entanto, o caráter complementar, no sentido de integrar crianças e adolescentes nas prestações realizadas pelo Estado.

\footnotetext{
${ }^{246}$ Art. 229. Os pais têm o dever de assistir, criar e educar os filhos menores, e os filhos maiores têm o dever de ajudar e amparar os pais na velhice, carência ou enfermidade.

${ }^{247} \mathrm{O}$ requisito de demonstração de freqüência escolar, inserido no artigo 67 da Lei $\mathrm{n}^{\circ}$ 8.213/1991 pela Lei $\mathrm{n}^{\circ}$ 9.876 de vinte e seis de novembro de 1999, teve sua constitucionalidade desafiada na ADI $n^{\circ} 2110-9$, que ainda pende de julgamento final. Todavia, o plenário do STF indeferiu, por maioria de votos, o pedido liminar de suspensão cautelar da eficácia do dispositivo que promovia a inclusão.
} 
Quanto à sociedade, aqui entendida como corpo social geral, repete-se o mesmo caráter de dever de viabilização da educação formal. Nesse aspecto é emblemático o $\S 5^{\circ}$ do artigo 212 da Constituição Federal de 1988, que estabelece a contribuição social do salário-educação. Esse tributo somar-se-á às demais fontes tributárias para financiar a educação básica pública.

Teriam natureza semelhante as previsões de vinculação de receita de impostos para aplicação em educação constantes do artigo 212 da Constituição Federal de 1988 (dezoito por cento para a União e vinte e cinco por cento para os Estados ${ }^{248}$, o Distrito Federal e os Municípios), bem como a instituição de fundo especificamente voltado à educação, como faz o artigo 60 do Ato das Disposições Constitucionais Transitórias da Constituição Federal de 1988. O tema do financiamento da educação será retomado mais adiante. Todavia, cumpre salientar neste momento que se trata de normas que demonstram o dever mais evidente da sociedade frente à educação formal: o de custeá-la.

Entretanto, como já afirmado, o principal submetido à oponibilidade do direito social à educação é o Estado. Nesse sentido, visando à maior efetividade do direito, a Constituição Federal de 1988 organizou as diferentes prestações educacionais entre as esferas federativas brasileiras da seguinte forma:

Art. 211. A União, os Estados, o Distrito Federal e os Municípios organizarão em regime de colaboração seus sistemas de ensino.

$\S 1^{\circ}$. A União organizará o sistema federal de ensino e o dos Territórios, financiará as instituições de ensino públicas federais e exercerá, em matéria educacional, função redistributiva e supletiva, de forma a garantir equalização de oportunidades educacionais e padrão mínimo de qualidade do ensino mediante assistência técnica e financeira aos Estados, ao Distrito Federal e aos Municípios.

$\S 2^{\circ}$ Os Municípios atuarão prioritariamente no ensino fundamental e na educação infantil.

$\S 3^{\circ}$. Os Estados e o Distrito Federal atuarão prioritariamente no ensino fundamental e médio.

Numa demonstração do caráter cooperativo do federalismo brasileiro, portanto, a Constituição Federal de 1988 divide a responsabilidade pela educação básica entre Municípios (educação infantil e ensino fundamental) e Estados (ensino fundamental e ensino médio), deixando à União um papel suplementar. Evidentemente, a divisão não se

\footnotetext{
${ }^{248}$ No âmbito do Estado de São Paulo, a Constituição estadual paulista estabelece, no artigo 255, a aplicação na manutenção e no desenvolvimento do ensino público não menos de trinta por cento da receita resultante de impostos, aí incluídos os recursos provenientes de transferências financeiras.
} 
opera quanto ao Distrito Federal, em que pese a menção no $\S 3^{\circ}$ do artigo transcrito, já que esse ente federativo acumula tanto competências estaduais como municipais (artigo 32, § $1^{\text {o }}$, da Constituição Federal de 1988).

Nesse contexto, recorde-se que o $\S 2^{\circ}$ do artigo $5^{\circ}$ da Lei $n^{\circ} 9.394 / 1996^{249}$ determina ao poder público das diferentes esferas federativas que assegurem, primeiramente, o ensino obrigatório, contemplando na seqüência os demais níveis e modalidades de ensino ${ }^{250}$. No entanto, a já mencionada Emenda Constitucional n 59/2009 estendeu a obrigatoriedade a toda a educação básica. À primeira vista, assim, o $\S 2^{\circ}$ do artigo $5^{\circ}$ da Lei $n^{\circ}$ 9.394/1996 teria perdido a maior parte de sua eficácia, restando apenas implicações condicionantes em relação à criação de instituições de ensino superior. Todavia, essa parcial ineficácia operará de modo progressivo. Isto porque o artigo $6^{\circ}$ da Emenda Constitucional n ${ }^{\circ}$ 59/2009 determina que a implantação da obrigatoriedade da educação básica dar-se-á progressivamente, até 2016, nos termos do Plano Nacional de Educação, com apoio técnico e financeiro da União.

Para concluir este tópico, cabe a ressalva de que, evidentemente, os entes federativos poderão atuar em outros níveis educacionais além daqueles que lhes foram expressamente atribuídos no mencionado artigo 211 e parágrafos. No entanto, certo é que o texto constitucional não possui palavras inúteis. De modo que ao utilizar o termo prioritariamente para caracterizar a atuação dos Municípios face à educação infantil e ao ensino fundamental e a atuação dos Estados frente ao ensino fundamental e médio, a Constituição Federal de 1988 determinou, implicitamente, que os entes federativos apenas podem dedicar-se a outros níveis de ensino se atenderem integralmente os seus níveis prioritários $^{251}$. No que tange aos Municípios essa limitação está expressamente prevista no artigo 11, inciso V, da Lei ${ }^{\circ}$ 9.394/1006:

\footnotetext{
${ }^{249} \mathrm{O}$ mesmo teor consta do $\S 2^{\circ}$ do artigo 54 da Lei $\mathrm{n}^{\circ} 8.069 / 1990$, de modo que a este dispositivo aplicamse as mesmas conclusões acerca do $\S 2^{\circ}$ do artigo $5^{\circ}$ da Lei $n^{\circ}$ 9.394/1996.

${ }^{250} \mathrm{Na}$ esfera municipal, entretanto, a jurisprudência já está consolidada no sentido de determinar o atendimento em creche e pré-escola, por imposição constitucional expressa, sem fazer referência à implementação do ensino fundamental como condicionante da satisfação da educação infantil. Nesse sentido, ver: "a jurisprudência do Supremo Tribunal Federal firmou-se no sentido da existência de direito subjetivo público de crianças até cinco anos de idade ao atendimento em creches e pré-escolas. Do outro lado, o Supremo Tribunal também consolidou o entendimento de que é possível a intervenção do Poder Judiciário visando à efetivação daquele direito constitucional" in Brasil, SUPREMo TRIBUnAl Federal, Agravo Regimental no Recurso Extraordinário n ${ }^{\circ}$ 554075-8, Ministra Relatora Cármen Lúcia, DJ 21.08.2009, p. 5.

${ }^{251}$ Nesse sentido a lição de GARCIA: "[o] sistema atual atribuiu aos Municípios a atuação prioritária no ensino fundamental e infantil e aos Estados e ao Distrito Federal, também de forma prioritária, a manutenção do ensino fundamental e médio. Com isto, é possível afirmar que inexiste qualquer óbice a que tais entes
} 
Art. 11. Os Municípios incumbir-se-ão de: (...)

V - oferecer a educação infantil em creches e pré-escolas, e, com prioridade, o ensino fundamental, permitida a atuação em outros níveis de ensino somente quando estiverem atendidas plenamente as necessidades de sua área de competência e com recursos acima dos percentuais mínimos vinculados pela Constituição Federal à manutenção e desenvolvimento do ensino.

Verificada a questão da oponibilidade, o estudo da estrutura essencial do direito social à educação ainda depende da verificação de seu objeto.

\subsubsection{Objeto}

Objeto é entendido como o conteúdo substancial do direito social à educação. Porém, é importante que se compreenda que se trata, aqui, do objeto do direito à educação, e não do objeto da educação em si. Este, evidentemente, está intimamente ligado àquele, sendo certo que o Estado interfere no tema do conteúdo da educação propriamente dita. Nesse sentido são as previsões do artigo 210 da Constituição Federal de 1988, e seus parágrafos $^{252}$. No entanto, o que se denomina aqui de objeto refere-se ao conjunto de elementos essenciais que, desde a previsão constitucional, caracterizam o direito social à educação.

Esse conjunto pode ser sintetizado através dos seguintes elementos: (i) o acesso às prestações educacionais, (ii) o sentido teleológico da atividade educacional

federativos atuem em outros níveis de educação, o que, por óbvio, pressupõe o atendimento satisfatório nos níveis em que sua atuação seja prioritária" in GARCIA, Emerson, O Direito à Educação e suas Perspectivas de Efetividade, in GARCIA, Emerson (coord.), A Efetividade dos Direitos Sociais, Rio de Janeiro, Lumen Juris, 2004, pp 166 e 167. O tema da prioridade também já foi lembrado em julgado do Supremo Tribunal Federal: "Os Municípios - que atuarão, prioritariamente, no ensino fundamental e na educação infantil (CF, art. $211, \S 2^{\circ}$ ) - não poderão demitir-se do mandato constitucional, juridicamente vinculante, que lhes foi outorgado pelo art. 208, IV, da Lei Fundamental da República, e que representa fator de limitação da discricionariedade político-administrativa dos entes municipais, cujas opções, tratando-se do atendimento das crianças em creche (CF, art. 208, IV), não podem ser exercidas de modo a comprometer, com apoio em juízo de simples conveniência ou de mera oportunidade, a eficácia desse direito básico de índole social” in BRASIL, Supremo Tribunal Federal, Recurso Extraordinário n 436996, Ministro Relator Celso de Mello, DJ 07.11.2005, Decisão Monocrática; e, mais recentemente, "Educação infantil. Criança de até seis anos de idade. Atendimento em creche e pré-escola. Direito assegurado pelo próprio Texto Constitucional $(\mathrm{CF}$, art. 208, IV). Compreensão global do direito à educação. Dever jurídico cuja execução se impõe ao Poder Público, notadamente ao Município (CF, art. 211, § $2^{\circ}$ )" in BrASIL, SuPrEMo Tribunal FEDERAL, Agravo Regimental no Recurso Extraordinário n 592937, Ministro Relator Cezar Peluso, DJ 05.06.2009.

${ }^{252}$ Art. 210. Serão fixados conteúdos mínimos para o ensino fundamental, de maneira a assegurar formação básica comum e respeito aos valores culturais e artísticos, nacionais e regionais. $\S 1^{\circ}-\mathrm{O}$ ensino religioso, de matrícula facultativa, constituirá disciplina dos horários normais das escolas públicas de ensino fundamental. $\S 2^{\circ}$ - O ensino fundamental regular será ministrado em língua portuguesa, assegurada às comunidades indígenas também a utilização de suas línguas maternas e processos próprios de aprendizagem. 
constitucionalmente estabelecido, (iii) a gratuidade da educação em estabelecimentos oficiais, (iv) o direito a programas suplementares; e, (v) a garantia da educação de qualidade.

(i) Sobre o primeiro elemento, remete-se ao que foi apresentado acima acerca das prestações educacionais identificadas por grupo etário. Ou seja, são parte (principal) do objeto do direito social à educação as diferentes fases do processo de ensino institucional: educação infantil, ensino fundamental e ensino médio (perfazendo a educação básica), além do ensino superior para aqueles que demonstrarem a capacidade necessária. Cada uma dessas etapas, então, corresponderá ao objeto essencial do direito social à educação do grupo etário que detém sua titularidade.

Cumpre acrescentar que esse acesso deve operar-se em atendimento ao fundamento previsto no inciso I do artigo 206 da Constituição Federal de 1988. Vale dizer, o ensino deve ser ministrado em igualdade de condições de acesso e permanência. Trata-se, portanto, de um direito de acesso isonômico às prestações educacionais. Inclusive, esse é o sentido de um dos deveres constitucionais expressos do Estado em relação à educação: ofertar ensino noturno regular, adequado às condições do educando (artigo 208, inciso VI, da Constituição Federal de 1988).

(ii) O sentido teleológico da atividade educacional vem expresso no artigo 205 da Constituição Federal de 1988. Como já visto anteriormente, a educação deve estar voltada ao pleno desenvolvimento da pessoa, seu preparo para o exercício da cidadania e sua qualificação para o trabalho. A abstração e ampla abrangência desses objetivos certamente implicam dificuldades quanto à sua operabilidade jurídica. Todavia, conforme ensina HORTA, é possível extrair deles uma exigência de que a educação formal seja conduzida com máxima finalidade ética ${ }^{253}$.

Trata-se de um compromisso do poder público em relação a uma educação que, na sua substância, deve relacionar-se com os fundamentos da República brasileira, conforme definidos no artigo $1^{\circ}$ da Constituição Federal de 1988. De fato, conforme salienta PIERDONÁ ${ }^{254}$, os objetivos ínsitos no artigo 205 da Constituição Federal de 1988 fazem

\footnotetext{
${ }^{253}$ HorTA, José Luiz Borges, Direito Constitucional da Educação, Belo Horizonte, Decálogo, 2007, pp. 125 a 128.

${ }^{254}$ PierdonÁ, Zélia Luiza, Objetivos Constitucionais da Educação e sua Relação com os Fundamentos do Estado Brasileiro, in FERREIRA, Dâmares, Direito Educacional em Debate, São Paulo, Cobra, 2004, pp. 113 a 129.
} 
referência direta a três incisos de seu artigo $1^{\circ}$ : a dignidade da pessoa humana (inciso III), a cidadania (inciso II) e o valor social do trabalho (inciso IV).

De modo bastante claro, MALISKA ${ }^{255}$ compreende essa relação entre os objetivos constitucionais da educação e os fundamentos da República como um indicador de que a educação deve cumprir ao menos dois papéis essenciais: promover a autonomia individual e servir de instrumento permanente de aperfeiçoamento humanístico da sociedade.

Nesse sentido, a atividade de ensino deve assegurar aos indivíduos que tomem consciência dos direitos e deveres que lhes cabem como membros da sociedade e que adquiram a capacidade técnico-profissional suficiente para usufruírem de uma existência mínima digna. Já sobre o aperfeiçoamento humanístico, as palavras de MALISKA são precisas: "[a] educação promove a visão de mundo das pessoas, a forma como elas vão ver os acontecimentos na sua cidade, no seu país e no mundo. Ela pode e deve ter (...) a função de superação das concepções de mundo marcadas pela intolerância, pelo preconceito, pela discriminação, pela análise não crítica dos acontecimentos"256.

RANIERI $^{257}$, em complementação, aponta para o vínculo necessário entre a educação formal e os objetivos da República, contidos no artigo $3^{\circ}$ da Constituição Federal de 1988 (construir uma sociedade livre, justa e solidária; garantir o desenvolvimento nacional; erradicar a pobreza e a marginalização e reduzir as desigualdades sociais e regionais; promover o bem de todos, sem preconceitos de origem, raça, sexo, cor, idade e quaisquer outras formas de discriminação). Nesse contexto, conforme leciona a autora, a preparação para a participação no espaço público é elemento primordial.

Esse papel da educação, que RANIERI define como exigência constitucional para o exercício da cidadania, constitui "medida de interesse público e condição de funcionamento da sociedade estatal" ${ }^{, 258}$. Ele age como um reconhecimento jurídico de que a formação axiológica ${ }^{259}$ dos indivíduos não pode ser confiada exclusivamente à

\footnotetext{
${ }^{255}$ Maliska, Marcos Augusto, Educação, Constituição e Democracia, in SouZA Neto, Cláudio Pereira et SARMEnTo, Daniel (coord.), Direitos Sociais, Fundamentos Judicialização e Direitos Sociais em Espécie, Rio de Janeiro, Lumen Júris, 2008, pp. 789 a 800.

${ }^{256}$ Maliska, Marcos Augusto, Educação, Constituição ..., cit., p. 790.

${ }^{257}$ RANIERI, Nina Beatriz Stocco, O Estado Democrático... cit., pp. 356 e 372.

${ }^{258}$ RANIERI, Nina Beatriz Stocco, O Estado Democrático... cit., p. 357.

${ }^{259}$ Conforme ensina RANIERI, num Estado Democrático de Direito o conteúdo dessa formação compreende os valores que dão suporte à Democracia e à República, em torno dos quais gravitam os inúmeros conceitos de educação ética, educação política, educação para direitos humanos, educação para a democracia etc., in RANIERI, Nina Beatriz Stocco, O Estado Democrático... cit., p. 358. Registre-se, nesse sentido, a Declaração do Cairo sobre Educação para Direitos Humanos e sua Disseminação, adotada no âmbito da Conferência sobre Educação para Direitos Humanos e sua Disseminação, em outubro de 2000, que entre seus primeiros
} 
autonomia familiar. O Estado tem interesse nessa formação, o que justifica a previsão constitucional dos objetivos da educação formal, que no artigo 205 da Constituição Federal de 1988 vinculam o pleno desenvolvimento da personalidade humana à participação na vida da coletividade e no espaço público (mediante o trabalho, o exercício de direitos, o cumprimento de deveres e a participação política propriamente dita).

$\mathrm{Na}$ esfera da legislação infraconstitucional, esse teor pode ser verificado no inciso I do artigo 27 da Lei $\mathrm{n}^{\circ}$ 9.394/1996, que determina que os conteúdos da educação básica devam buscar "a difusão de valores fundamentais ao interesse social, aos direitos e deveres dos cidadãos, de respeito ao bem comum e à ordem democrática". Também está presente nos incisos II, III e IV do artigo 32 do mesmo diploma, que estabelecem como objetivos ao conteúdo do ensino fundamental "a compreensão do ambiente natural e social, do sistema político, da tecnologia, das artes e dos valores em que se fundamenta a sociedade", "o desenvolvimento da capacidade de aprendizagem, tendo em vista a aquisição de conhecimentos e habilidades e a formação de atitudes e valores", e "o fortalecimento dos vínculos de família, dos laços de solidariedade humana e de tolerância recíproca em que se assenta a vida social". Esse mesmo teor consta, ainda, do inciso III de seu artigo 35, ao prever como finalidade do ensino médio "o aprimoramento do educando como pessoa humana, incluindo a formação ética e o desenvolvimento da autonomia intelectual e do pensamento crítico"260.

(iii) A gratuidade da educação em estabelecimentos oficiais vem prevista no inciso IV do artigo 206 da Constituição Federal de 1988:

Art. 206. O ensino será ministrado com base nos seguintes princípios: (...)

IV - gratuidade do ensino público em estabelecimentos oficiais;

Evidentemente, ao prever a gratuidade como princípio do ensino pátrio, o constituinte quis que o caráter gratuito consubstanciasse fundamento de organização

objetivos arrola: (i) o "[d] esenvolvimento e o florescimento da personalidade humana nas suas dimensões espiritual, intelectual e social, e [o] fortalecimento da noção do povo acerca de dignidade, liberdade, igualdade, justiça social e prática democrática" e (ii) o "[a]umento em homens e mulheres da consciência de seus direitos de modo a permitir-lhes transformas os princípios de direitos humanos em realidade social, econômica e política. Isto também permitir-lhes-á aumentar suas capacidade de defender, manter e desenvolver os direitos humanos em todos os níveis" (tradução livre).

${ }^{260}$ Sobre o tema, é digna de nota a recente alteração realizada pela Lei ${ }^{\circ} 12.031$, de 21 de setembro de 2009 , no artigo 39 da Lei $\mathrm{n}^{\circ} 5.700$, de $1^{\circ}$ de setembro de 1971, inserindo-lhe um parágrafo único para prever a obrigatoriedade de execução do Hino Nacional nos estabelecimentos públicos e privados de ensino fundamental ao menos uma vez por semana. 
estatal, aplicável à integralidade da atividade oficial de educação ${ }^{261}$. Sobre a extensão dessa previsão, o intérprete pode socorrer-se da exegese que dela já foi feita pelo Supremo Tribunal Federal.

O tema da gratuidade foi objeto do recurso extraordinário $\mathrm{n}^{\circ} 500.171-7^{262}$, de relatoria do Ministro Ricardo Lewandowski. No caso do recurso, decidiu-se acerca da inconstitucionalidade da cobrança de taxa de matrícula em universidades públicas federais, matéria cuja repercussão geral para fins de acesso à via extraordinária já havia sido reconhecida por ocasião do recurso extraordinário $n^{\circ} 567.801$, decidido em 15 de fevereiro de 2008.

Na fundamentação do acórdão, o Ministro Ricardo Lewandowski considerou equivocadas interpretações restritivas do artigo 206, inciso IV, da Constituição Federal de 1988, ainda que combinado com o artigo $208^{263}$, inciso I, que impliquem redução do âmbito de incidência da gratuidade do ensino em estabelecimentos oficias. Não tendo a Constituição Federal de 1988 feito exceções expressas à gratuidade segundo o grau de ensino, não cabe ao aplicador da norma criá-las.

Essa foi a linha de raciocínio do Ministro relator: “[a] rigor, o disposto no art. 208, longe de consubstanciar uma limitação à educação gratuita, em verdade assinala ao Estado a obrigação de manter uma estrutura institucional que permita ao cidadão comum, tenha ou não recursos financeiros, o acesso ao ensino superior, em seus vários níveis, da graduação à pós-graduação, ministrado em estabelecimentos oficiais, tendo como única limitação a sua competência intelectual. Além disso, a gratuidade do ensino público em estabelecimento oficiais, conforme se lê no caput do art. 206, IV, configura um princípio. Um princípio que não encontra qualquer limitação, no tocante aos distintos graus de formação acadêmica"264.

\footnotetext{
${ }^{261}$ Nesse sentido apresenta-se a lição de SILVA: "se a Constituição estabeleceu que a educação é direito de todos e dever do Estado, significa que a elevou à condição de serviço público a ser prestado pelo Poder Público indiscriminadamente e, portanto, gratuitamente aos usuários, ficando seu custeio por conta das arrecadações gerais do Estado" in SILVA, José Afonso da, Curso de ... cit., p. 178.

${ }^{262}$ Decisões posteriores no mesmo sentido: Recurso Extraordinário $\mathrm{n}^{\circ}$ 562.779, Relator Ministro Ricardo Lewandowski (DJ 26.02.2009); Recurso Extraordinário ${ }^{\circ}$ 510.378, Relator Ministro Ricardo Lewandowski (DJ 23.10.2008); Recurso Extraordinário $n^{\circ}$ 552.917, Relator Ministro Eros Grau (DJ 18.12.2008).

${ }^{263}$ No caso concreto, o inciso I do artigo 208 (à época garantidor do ensino fundamental gratuito de forma absoluta, mas recentemente alterado pela $\mathrm{EC} \mathrm{n}^{\circ}$ 59/2009 para abranger toda a educação básica) foi usado pela instituição de ensino recorrente como argumento para defender a tese de que apenas quanto ao ensino fundamental haveria a imposição constitucional de gratuidade.

${ }^{264}$ BRASIL, SUPREMO TRIBUNAL FEDERAL, Recurso Extraordinário $n^{\circ}$ 500171, Ministro Relator Ricardo Lewandowski, DJ 23.10.2008.
} 
Também é digno de transcrição o asseverado, na mesma decisão, pelo Ministro Cezar Peluso em seu voto: “a importância constitucional ao direito social à educação como um dos mais relevantes como condição básica para exercício concreto de cidadania, levame a pensar que a interpretação do art. 206, IV, que introduz um princípio, nunca pode ser restritiva, devendo, antes, ser sempre generosa. Daí, esse princípio deve ser entendido no significado mais amplo possível. (...) O condicionamento de uma taxa para efeito de inscrição no vestibular ou para efeito de matrícula, a meu ver, é restrição clara ao

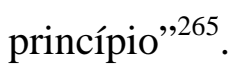

Nesses termos, o caráter extensivo da gratuidade de ensino conforme entendida pelo Supremo Tribunal Federal fundamentou decisão recente do Tribunal de Justiça do Estado de São Paulo que reconheceu sua aplicabilidade inclusive quanto a taxas de inscrição em exames vestibulares de acesso ao ensino superior ${ }^{266}$.

Por fim, registre-se que especificamente acerca da cobrança de taxa de matrícula em universidades públicas foi editada Súmula Vinculante ${ }^{267}$ reconhecendo a inconstitucionalidade dessa prática.

(iv) Também compõe o direito social à educação o direito a programas suplementares. Estes se destinam a viabilizar a efetivação do direito à educação através de necessidades materiais que não se referem diretamente à atividade educacional, mas que possuem a mesma ordem de importância. Trata-se de providências asseguradoras tanto do ingresso como da permanência dos educandos no sistema de ensino.

A previsão constitucional da obrigatoriedade do Estado de fornecer tais prestações encontra-se arrolada sob o enunciado programas suplementares, identificando necessidades referentes a material didático-escolar, transporte, alimentação e assistência à saúde. O dispositivo em questão é o inciso VII do artigo 208 da Constituição Federal de 1988, que, em seu texto original estabelecia esse tipo de dever estatal apenas quanto aos alunos do ensino fundamental. Entretanto, com a recente alteração promovida pela Emenda

\footnotetext{
265 Brasil, Supremo Tribunal Federal, Recurso Extraordinário n ${ }^{\circ}$ 500.171, Relator Ministro Ricardo Lewandowski, DJ 23.10.2008.

266 “o art. 206, inciso IV, da Carta Magna, estabelece princípio que rege toda a atividade educacional, ou seja, o da gratuidade do ensino público em estabelecimento oficial" in EsTADO DE SÃo PAULO, TRIBUNAL DE JUSTIÇA, Apelação Cível n ${ }^{\circ}$ 444.127.5/6-00, Relator Desembargador Ricardo Feitosa, DJ 13.01.2010.

${ }^{267}$ Súmula Vinculante $\mathrm{n}^{\circ} 12$. A cobrança de taxa de matrícula nas universidades públicas viola o disposto no art. 206, IV, da Constituição Federal.
} 
Constitucional n 59/2009, a obrigação do Estado de fornecer programas suplementares foi estendida a toda a educação básica ${ }^{268}$.

Adicionalmente, registre-se que referida extensão deve contar com aplicabilidade imediata. Isso porque o artigo $6^{\circ}$ da Emenda Constitucional $n^{\circ}$ 59/2009 estabelece a implementação progressiva de suas modificações, até o ano de 2016, exclusivamente quanto ao inciso I do artigo 208, relacionado à universalização da educação básica obrigatória e gratuita dos quatro aos dezessete anos. Considerando que o inciso VII do artigo 208 traz norma de atribuição e proteção de direitos fundamentais, seria descabido interpretar extensivamente o artigo $6^{\circ}$ da Emenda Constitucional $n^{\circ}$ 59/2009 de modo a criar restrição ao direito a programas suplementares não feita pelo constituinte reformador.

Especificamente acerca do transporte escolar, o dever de Estados, Distrito Federal e Municípios quanto aos alunos dos respectivos sistemas de ensino é repetido pelo inciso VII do artigo 10 e pelo inciso VI do artigo 11 da Lei $\mathrm{n}^{\circ}$ 9.394/1996. No mesmo sentido, o artigo 53 da Lei $n^{\circ} 8.069 / 1990$ assegura a crianças e adolescentes o direito de acesso à escola pública e gratuita próxima de sua residência.

Vale registrar que, para fins de atendimento aos percentuais mínimos de aplicação de recursos na educação, estabelecidos pelo artigo 212 da Constituição Federal de 1988, os gastos com programas suplementares podem ser considerados como despesas com a manutenção e o desenvolvimento do ensino, subsumindo-se às hipóteses definidoras do artigo $70^{269}$ da Lei $n^{\circ} 9.394 / 1996$.

Encontram-se, na jurisprudência, decisões que apresentam os programas suplementares como elementos inerentes ao direito à educação. Confira-se, exemplificativamente, a Suspensão de Tutela Antecipada (STF) n 318: “[d]e fato, em um exame perfunctório, verifico que o Estado Membro deve assumir o fornecimento de transporte escolar aos alunos de ensino médio" ${ }^{, 70}$. Em termos semelhantes, decidiu o

\footnotetext{
${ }^{268}$ Art. 208. O dever do Estado com a educação será efetivado mediante a garantia de: (...) VII - atendimento ao educando, em todas as etapas da educação básica, por meio de programas suplementares de material didático escolar, transporte, alimentação e assistência à saúde.

${ }^{269}$ Art. 70. Considerar-se-ão como de manutenção e desenvolvimento do ensino as despesas realizadas com vistas à consecução dos objetivos básicos das instituições educacionais de todos os níveis, compreendendo as que se destinam a: (...) III - uso e manutenção de bens e serviços vinculados ao ensino; (...) V - realização de atividades-meio necessárias ao funcionamento dos sistemas de ensino; (...) VIII - aquisição de material didático-escolar e manutenção de programas de transporte escolar.

${ }^{270}$ Supremo Tribunal Federal, Suspensão de Tutela Antecipada n ${ }^{\circ} 318$, Decisão do Presidente Ministro Gilmar Mendes, DJ 24.04.2009. No mesmo sentido, ao dar provimento ao Recurso Extraordinário interposto pelo Ministério Público paulista contra acórdão do Tribunal de Justiça do Estado de São Paulo que havia cancelado sentença que condenava a Fazenda estadual em obrigação de fazer consistente na regularização do
} 
Tribunal de Justiça do Estado de São Paulo: “[o] não fornecimento do transporte escolar gratuito pela Municipalidade de Bauru e pelo Estado de São Paulo aos apelantes, que desse transporte dependem para estudarem, ofende o direito à educação assegurado pela Constituição da República (...) [A] única forma de igualar condições entre os alunos que residem perto e longe das escolas é proporcionar a estes últimos transporte gratuito, evitando com isso a evasão escolar e a baixa escolaridade da população" ${ }^{271}$.

Como um dos elementos que compõem o direito social à educação, o dever de fornecimento de programas suplementares é um reflexo lógico do fundamento da ordem educacional ínsito no inciso I do artigo 206 da Constituição Federal de 1988: a igualdade de condições para o acesso e permanência na escola. Em relação a material didáticoescolar, transporte, alimentação e assistência à saúde, é dever do Estado preparar-se para que alunos insertos em diferentes realidades materiais possam iniciar e percorrer satisfatoriamente todo o processo educativo.

(v) Das decisões já colacionadas depreende-se que a tendência na jurisprudência brasileira é reconhecer incondicionadamente a normatividade do direito fundamental à educação. Evidentemente, isso apenas será suficiente à medida que se entender que esse direito somente se integraliza se, para além de acesso, finalidades, gratuidade e programas suplementares, for também assegurada a qualidade de sua prestação mais evidente: o processo educativo.

Certamente, é no tema da qualidade da educação que reside a maior deficiência de concretização do direito social à educação do Brasil. Historicamente, em especial nas últimas três décadas, as contradições entre demanda e oferta de educação no Brasil

transporte escolar gratuito, o Ministro Eros Grau decidiu: “[a] educação é um direito fundamental e indisponível dos indivíduos. É dever do Estado propiciar meios que viabilizem o seu exercício. A omissão administrativa impede que o Poder Público cumpra integralmente dever a ele imposto pela Constituição do Brasil" in SUPREMO TRIBUNAL FEDERAL, Recurso Extraordinário n ${ }^{\circ} 293.412$, Relator Ministro Eros Grau, DJ 29.05.2006.

271 Estado De São Paulo, Tribunal de JustiçA, Apelação Cível n 320.962.5/1-00, Relator Desembargador Antonio Rulli, DJ 03.10.2006. No mesmo sentido: “[a] concessão da segurança pleiteada era mesmo de rigor, sendo reconhecido, com inteiro acerto, que a Prefeitura-ré está obrigada a fornecer transporte escolar ao impetrante, aluno do ensino fundamental residente na zona rural e que estuda no centro da cidade de Buritizal. Com efeito, a Constituição Federal impõe aos entes estatais o dever de assegurar o ensino fundamental, obrigatório e gratuito, inclusive para os que a ele não tiveram acesso na idade própria, preconizando amplo atendimento ao educando através da implementação de programas suplementares de material didático-escolar, transporte, alimentação e assistência à saúde" in TRIBUNAL DE JUSTIÇA, Apelação Cível $\mathrm{n}^{\circ}$ 538.341.5/2-00, Relator Desembargador Paulo Dimas Mascaretti, DJ 22.07.2008. Conferir, adicionalmente, TRIBUnAL DE JustiçA, Apelação Cível n 683.982.5/0-00, Relator Desembargador Moacir Peres, DJ 21.01.2008. 
transferiram-se progressivamente ao longo do processo educativo, na medida em que o problema diretamente anterior era resolvido ${ }^{272}$.

O primeiro desafio foi o aumento da rede física, em resposta à demanda pela expansão do número de vagas nas séries de entrada no processo educativo. A preocupação seguinte é manter os alunos no ciclo, reduzindo-se os índices de evasão escolar e aumentando o número de alunos que concluem o ensino fundamental. Sequencialmente, deve-se abordar o problema dos altos índices de repetência e dedicar esforços no sentido de se obter a regularização do fluxo de escolarização (números semelhantes de alunos em cada uma das séries da educação básica). Conforme salienta OLIVEIRA, a "adoção de ciclos, da promoção automática e de programas de aceleração da aprendizagem"273 foram algumas das 'soluções' (muitas vezes infelizes) desenvolvidas para enfrentar o problema do progresso no sistema educacional.

O índice de Desenvolvimento Educacional do Brasil, recentemente divulgado pela UNESCO como anexo do Relatório de Monitoramento Global do Compromisso Educação para Todos $^{274}$ (adotado em Dakar em 2000), é emblemático acerca da situação. No índice geral, o Brasil amargou a décima oitava posição entre cento e vinte e oito países, com um Índice de Desenvolvimento Educacional de 0,883, logo atrás de Honduras $(0,885)$ e à frente do Suriname $(0,882)$. A revelação ocorre com a inspeção da composição do índice, que se dá pela conjugação de quatro outros índices, também calculados pela UNESCO. Nos três primeiros, que medem a universalização do acesso aos primeiros anos da educação, a alfabetização entre os adultos e a isonomia de gênero em relação às oportunidades educacionais, o Brasil obteve 0,935, 0,900 e 0,942, respectivamente. São taxas ainda insatisfatórias, dado que a UNESCO considera como alto Índice de Desenvolvimento Educacional aquele que for superior a 0,950. Todavia, é o quarto índice que revela a mais grave deficiência brasileira. Nele, que mede a qualidade da educação (através da quantificação da sobrevivência dos alunos até a quinta série da educação quarto ano do ensino fundamental no caso brasileiro), o Brasil obteve o número de 0,756, ficando em centésimo terceiro de cento e vinte e oito países nesse quesito específico.

272 Cf. OliveIRA, Romualdo Portela de, Da Universalização do Ensino Fundamental ao Desafio da Qualidade, in Educação e Sociedade, v. 28, n. 100, 2007.

273 OliveIRA, Romualdo Portela de, Qualidade do Ensino: Uma Nova Dimensão da Luta pelo Direito à Educação, in Revista Brasileira de Educação, n 28, 2005, p. 10.

274 UNESCO, Education for All - Global Monitoring Report, 2010, disponível em http://www.unesco.org/en/efareport/reports/2010-marginalization. 
A dimensão de ineficácia do direito à educação é, portanto, magnificada em relação à garantia de qualidade. A correção desse desvio da realidade pelas vias jurídicas, no entanto, depende de clareza acerca do dever que corresponde ao direito à educação de qualidade. Ou seja, para que se possa exigir, por subordinação jurídica ${ }^{275}$, que a educação seja prestada com qualidade, é necessário saber com algum nível de exatidão em que consiste essa prestação.

No plano do direito positivo, o tratamento constitucional da matéria é brevemente realizado com a enumeração entre os fundamentos do ensino brasileiro (artigo 206, inciso VII) e com sua previsão como elemento de fiscalização pelo poder público da atividade educacional desenvolvida pela iniciativa privada (artigo 209, inciso II) ${ }^{276}$. Há, também, a disposição do $\S 1^{\circ}$ do artigo 60 do Ato das Disposições Constitucionais Transitórias (ADCT), segundo a qual a União, os Estados, o Distrito Federal e os Municípios deverão assegurar, no financiamento da educação básica, a melhoria da qualidade de ensino, de forma a garantir padrão mínimo definido nacionalmente. De modo que, se por um lado a Constituição Federal de 1988 claramente garante a qualidade da educação, por outro ela não indica seu significado. RANIERI observa que nesse tema a Constituição apresenta-se com baixo nível de vinculação ao legislador ordinário: "o que é qualidade, quando e de que maneira será assegurado tal padrão fica a critério do legislador"277.

Por sua vez, a Lei n 9.394/1996, explicitando o modo pelo qual o Estado satisfaz seu dever com a educação escolar pública, define padrões mínimos de qualidade de ensino como a variedade e quantidade mínimas, por aluno, de insumos indispensáveis ao desenvolvimento do processo de ensino-aprendizagem (artigo $4^{\circ}$, inciso IX). A dificuldade hermenêutica transfere-se, então, a saber quais e em que quantidade são esses insumos indispensáveis.

Não se tem notícia de que o legislador brasileiro tenha feito essa definição. O que há, em seu lugar, é uma fixação contábil de um valor mínimo anual por aluno, estabelecido nacionalmente. Essa estimativa é definida pelo artigo $4^{\circ}, \S \S 1^{\circ}$ e $2^{\circ}$, da Lei ${ }^{\circ} 11.494$, de 20 de junho de 2007, que regulamenta o Fundo de Manutenção e Desenvolvimento da

\footnotetext{
${ }^{275}$ Recorde-se que a pretensão jurídica, conforme definida por CARNELUTTI, expressa uma exigência de subordinação do interesse alheio ao próprio. Cf. CARNELUTTI, Francesco, Sistema de derecho procesal civil, v. 1, Buenos Aires, UTEHA, 1944, p. 44.

276 Art. 206. O ensino será ministrado com base nos seguintes princípios: (...) VII - garantia de padrão de qualidade; (...) Art. 209. O ensino é livre à iniciativa privada, atendidas as seguintes condições: (...) II autorização e avaliação de qualidade pelo Poder Público.

${ }^{277}$ RANIERI, Nina Beatriz Stocco, O Estado Democrático... cit., p. 321.
} 
Educação Básica e de Valorização dos Profissionais da Educação (FUNDEB). Sua finalidade é permitir que a União complemente os recursos dos fundos estaduais (compostos por uma série de tributos vinculados para esse fim pelo artigo 60, inciso II, do ADCT) sempre que o valor médio ponderado por aluno em cada fundo não atingir o valor mínimo nacional.

Essa estratégia para garantir a aplicação de recursos em educação, embora louvável, não resolve o problema da ausência de clareza acerca dos padrões mínimos de qualidade. Do ponto de vista da tutela judicial do direito à educação, individual ou coletiva, a fixação de um valor mínimo presta-se ao controle da efetiva aplicação desse valor no processo de ensino-aprendizagem. Todavia, não torna em nada mais fácil a verificação da presença ou ausência dos insumos indispensáveis para garantir uma educação de qualidade.

Já foi mencionado o fato de a Constituição Federal de 1988 ter dedicado extenso tratamento acerca do direito à educação, permitindo afirmar que a política pública nessa matéria encontra-se definida constitucionalmente. Conforme leciona RANIERI, caracterizadas por intensa determinação de conteúdo e densidade de proteção, todas as normas constitucionais relativas ao direito à educação contam com força vinculante direta. Ou seja, "todas constituem padrões jurídicos de controle judicial e fator de interpretação normativa e têm aplicabilidade imediata" $" 278$.

Todavia, a despeito da justiciabilidade imediata da estrutura constitucional de proteção ao direito à educação, no seu componente qualidade existe uma grave dificuldade ao aplicador do direito. $\mathrm{O}$ que se traduz, inclusive, na ausência de jurisprudência sobre a matéria.

Dada a complexidade do tema, aqui brevemente comentado, não cabe nesta Dissertação a apresentação de propostas de lege ferend ${ }^{279}$. Entretanto, vale a constatação

\footnotetext{
${ }^{278}$ Essa conclusão fundamenta-se, inclusive, no ínsito no $\S 1^{\circ}$ do artigo $5^{\circ}$ da Constituição Federal de 1988 (§ $1^{\circ}$ - As normas definidoras dos direitos e garantias fundamentais têm aplicação imediata) in RANIERI, Nina Beatriz Stocco, O Estado Democrático... cit., pp. 335 e 336.

${ }_{279}$ De fato, conforme ressalta FURTADO, a qualidade do ensino depende de uma complexa conjugação de diversos instrumentos: "condições materiais para o ensino, tanto das instituições de ensino (existência em número suficiente, boas condições do edifício escolar, do equipamento físico disponível, limpeza e manutenção efetivos, fornecimento regular de água, energia elétrica etc.) como dos alunos (fornecimento de material escolar, merenda, transporte etc.); condições dos recursos humanos ligados ao ensino (formação adequada, atualização constante, remuneração condigna etc.); condições de natureza pedagógica (currículos adequados, metodologias apropriadas ao perfil do alunado etc.); resultados cognitivos do processo de aprendizagem aferíveis por meio de avaliações; etc." in FuRTADO, Marcelo Gasque, Padrão de Qualidade do Ensino in RANIERI, Nina Beatriz Stocco e RighetTI, Sabine, Direito à Educação: Aspectos Constitucionais, São Paulo, EDUSP, 2009, p. 177.
} 
de que a área de maior obscuridade jurídica acerca da matéria é a responsável pela maior parte da dimensão de ineficiência do direito à educação no Brasil ${ }^{280}$.

\subsubsection{Direito subjetivo público à educação.}

Na produção doutrinária até o ano de 2009 é freqüente a afirmativa de que a Constituição Federal de 1988 teria dedicado tratamento diferenciado ao ensino fundamental $^{281}$. Isso porque desde a sua promulgação, através da conjugação do inciso I e do $\S 1^{\circ}$ de seu artigo 208, a Carta brasileira sempre declarou ser a educação, na modalidade ensino fundamental, direito público subjetivo. Cumpre investigar os efeitos dessa declaração.

Em sua obra, KELSEN ${ }^{282}$ faz a importante recordação acerca dos múltiplos sentidos que a palavra direito pode assumir na língua alemã (Recht) e francesa (droit), o que também ocorre no idioma português. Enquanto na língua inglesa Law designa o conteúdo global da ordem jurídica e right identifica o direito atribuído a determinado indivíduo, nos demais idiomas a mesma palavra (Direito em português) serve aos dois propósitos. Mesmo quando atrelado ao sujeito (subjetivo), direito pode significar tão somente a ausência de vedação, no sentido de que ao indivíduo é permitido realizar determinada conduta, por não lhe ser proibida por norma qualquer. Pode, ademais, indicar a situação em que o indivíduo detém uma prerrogativa reconhecida juridicamente, que obriga outro indivíduo, ou mesmo toda a coletividade, a agir (ou omitir-se) de uma determinada forma em relação a ele.

Qual teria sido, então, o propósito do constituinte brasileiro ao afirmar, no $\S 1^{\circ}$ do artigo 208, que o ensino obrigatório e gratuito é direito público subjetivo? Certamente tinha algo a mais em vista do que apenas declarar a dicotomia entre direito objetivo (direito

\footnotetext{
${ }^{280}$ Sobre o que o direito pode fazer pela educação ver GLENN JR., Charles Leslie, What law can - and cannot - do in education reform, in R.CEJ, n. 31, 2005, PP 31 a 34.

${ }^{281}$ V. RANIERI, Nina Beatriz Stocco, O Estado Democrático... cit., p. 347; GARCIA, Emerson, O Direito à Educação... cit., p 169; TAVARES, André Ramos, Direito Fundamental à Educação, in SoUZA NETO, Cláudio Pereira e SARMENTo, Daniel (Coord.), Direito Sociais: Fundamentos, Judicialização e Direitos Sociais em Espécie, Rio de Janeiro, Lumen Juris, 2008, p. 774; SIFUENTES, Mônica, Direito Fundamental... cit., pp. 43 a 48. Exemplificativamente, confira-se as palavras de SIFUENTES: "Parece claro que houve nítida opção do legislador constituinte brasileiro em tornar o ensino fundamental prioritário, dentro do direito à educação. Tanto que apenas em relação a ele confere, de modo expresso no texto constitucional, a característica de acionabilidade imediata, decorrente de sua classificação como direito subjetivo público" in SIFUENTES, Mônica, Direito Fundamental... cit., p. 74.

${ }^{282}$ Kelsen, Hans, Teoria Pura do Direito, Coimbra, Armênio Amado, 1984, p. 184.
} 
como fenômeno objetivo, ou seja, a própria ordem jurídica) e direito subjetivo (direito ligado ao sujeito enquanto titular de poderes, obrigações e faculdades) ${ }^{283}$.

Na definição de JELLINEK sobre direito subjetivo (público) o foco encontra-se na relação entre o indivíduo titular de um direito e os bens e interesses objeto de sua vontade. Direitos individuais existem quando o ordenamento jurídico reconhece, considerando útil ao atendimento de suas próprias finalidades, a licitude de determinada relação entre vontade individual e seu objeto. Ou seja, reconhece ser lícito que um indivíduo pretenda determinado bem ou interesse ${ }^{284}$. Esse reconhecimento pelo ordenamento propicia um aumento da capacidade de agir do indivíduo. Esta, de tão somente física, passa a envolver também a capacidade "de exigir, no seu interesse, o reconhecimento e a atividade do Estado"285 (tradução livre). A partir dessa perspectiva, JELLINEK conclui que os direitos subjetivos (individuais) possuem sempre uma dimensão pública que expressa, exclusivamente, a capacidade de fazer as normas jurídicas entrarem em ação em prol do interesse individual. Essa pretensão jurídica de direito público ao reconhecimento e à tutela pelo Estado é que seria, para o autor, o conteúdo do direito público subjetivo ${ }^{286}$.

Segundo KELSEN, por sua vez, a essência do direito subjetivo encontra-se na existência de uma norma no ordenamento posto que crie ao titular do direito um poder jurídico de fazer valer, através de uma ação dirigida à autoridade competente para aplicação da norma, esse direito. Vale dizer, obter uma decisão judicial que estabeleça medidas concretas em oposição ao descumprimento do dever correspondente ao direito tutelado. Para KELSEN, esse sentido de poder jurídico conferido ao indivíduo é o sentido técnico da expressão direito subjetivo ${ }^{287}$.

\footnotetext{
${ }^{283}$ V. FerRAZ JUNIOR, Tercio Sampaio, Introdução ao Estudo do Direito: Técnica, Decisão, Dominação, São Paulo, Atlas, 2001, PP. 142 a 144.

${ }^{284}$ Conforme ensina JELLINEK, no plano físico, a vontade humana é limitada tão somente pelos limites corpóreos, independentemente de haver ou não adequação ao conteúdo das normas. Todavia, "o ordenamento jurídico pode acrescer à capacidade do indivíduo algo que ele não possui naturalmente. Isto é, ele pode conceder-lhe a faculdade de demandar que algumas de suas ações sejam reconhecidas como fato jurídico e que, como tais, sejam suscetíveis de tutela pelo Estado" (tradução livre) in JELLINEK, Georg, Sistema dei Diritti Pubblici Subbietivi, Milão, Libreria, 1912, p. 52.

${ }^{285}$ JELLINEK, Georg, Sistema ... cit., p. 53.

${ }^{286}$ Nas palavras do autor: "[o] direito público subjetivo, do ponto de vista formal, consiste portanto numa pretensão jurídica(...)" in JELLINEK, Georg, Sistema... cit., p. 57.

${ }^{287}$ Nas palavras do autor: "a essência do direito subjectivo, que é mais do que o simples reflexo de um dever jurídico, reside em que uma norma confere a um indivíduo o poder jurídico de fazer valer, através de uma acção, o não cumprimento de um dever jurídico. É a esta norma jurídica que nós nos referimos quando (...) falamos de um direito subjectivo em sentido técnico como de um poder jurídico conferido a um indivíduo" in Kelsen, Hans, Teoria Pura... cit., p. 197.
} 
Na doutrina nacional, FERRAZ JUNIOR, apesar de ressaltar que o conceito não pode ser tomado como uma realidade invariável, identifica na expressão direito subjetivo os seguintes elementos: (i) o sujeito do direito, isto é, seu titular; (ii) o conteúdo do direito, que exprime a faculdade específica de constranger o outro (ou de exercer o domínio sobre a coisa no casos dos direitos reais); (iii) o objeto do direito, que se refere ao bem protegido; e, finalmente, (iv) a "proteção do direito, isto é, a possibilidade de fazer valer o direito por meio da ação processual correspondente" 288 .

Com essa breve explanação quer-se demonstrar que a utilização pelo constituinte da expressão direito público subjetivo não pode ter tido outra finalidade senão a de deixar evidente aos intérpretes da Constituição Federal de 1988 que ao direito ao ensino obrigatório e gratuito corresponde um poder jurídico conferido ao indivíduo de valer-se das medidas judiciais cabíveis para exigir que o dever correspondente seja cumprido. Daí a importância de se conhecer com clareza a estrutura do direito à educação. Foi nesse sentido que se formulou acima a investigação acerca da titularidade, da oponibilidade e do objeto do direito à educação.

Como visto, a Constituição Federal de 1988 identificou os indivíduos titulares do direito à educação em cada uma de suas modalidades (sem deixar de resguardar a titularidade de toda coletividade num segundo plano). Definiu, ainda, de modo detalhado os objetivos e os programas governamentais que compõem o parâmetro de realização esperado para a satisfação do direito. E esclareceu, de modo evidente, que o dever jurídico reflexo ao direito social à educação recai primária e principalmente sobre o Estado. Fez isso no artigo 205, ao declarar textualmente o dever do Estado, também no artigo 208, caput, ao delinear em que consiste esse dever, e fez isso nos artigos 212 e 213 ao definir recursos e modo de sua aplicação para cumprimento desse dever.

Não bastasse, quis o constituinte deixar expresso que, ao menos no concernente ao ensino obrigatório e gratuito, é garantido ao particular o recurso ao controle judicial, em caso de eventual lesão ao direito social à educação ${ }^{289}$, sob pena de ofensa à Constituição.

\footnotetext{
${ }^{288}$ FERRAZ JUNIOR, Tercio Sampaio, Introdução... cit., p. 151.

289 V. DuARTe, Clarice Seixas, Direito Público Subjetivo e Políticas Educacionais, in São Paulo em Perspectiva, n. 18, 2004.
} 


\subsubsection{Do ensino fundamental à educação básica.}

O artigo 21 da Lei nº 9.394/1996 organiza a educação escolar em educação básica e educação superior, sendo que a primeira divide-se entre educação infantil, ensino fundamental e ensino médio. Os dispositivos seguintes ao artigo 21 dão o detalhamento da matéria. Ademais, como já mencionado, os mesmos conceitos são encontrados no texto constitucional, ainda que sem o mesmo nível de definição quanto a seu conteúdo e relações respectivas (artigo 206, incisos V e VII, parágrafo único; artigo 208, incisos I, II, IV e VII, e $\S 3^{\text {o }}$; artigo 210 , caput e $\S \S 1^{\circ}$ e $2^{\text {o }}$; artigo $211, \S \S 2^{\circ}, 3^{\circ}$ e $5^{\circ}$; artigo 212 , $\S 5^{\circ}$; e, artigo $\left.213, \S 1^{\circ}\right)$.

Todavia, um dos esclarecimentos que esteve na Constituição Federal de 1988 desde sua promulgação refere-se, como já mencionado, à conjugação entre o inciso I do artigo 208 e seu $\S 1^{\circ}$. Originalmente, extraia-se deste inciso I que era dever do Estado a garantia de ensino fundamental, obrigatório e gratuito, inclusive para os que a ele não tiveram acesso na idade própria ${ }^{290}$. A essa disposição o $§ 1^{\circ}$ sempre acrescentou a declaração de que o acesso ao ensino obrigatório e gratuito é direito público subjetivo.

É possível concluir que com essa organização adotada inicialmente, o constituinte de 1988 teria identificado o conteúdo do mínimo existencial do direito social à educação $^{291}$.

Admitindo-se, como se deve, que ao Estado não é possível atender a todas as demandas sociais, dado o caráter finito dos recursos, é também necessária a constatação de que a dignidade humana impõe como contraponto o argumento do mínimo existencial. Este é apresentado pela doutrina ${ }^{292}$ como a solução para se enfrentar a sombra de ineficácia que incide sobre os direitos sociais. Em linhas gerais, defende-se ser viável identificar um patamar mínimo de realização necessária de direitos sociais do qual decorreria um subconjunto de direitos perfeitamente exigíveis do poder público.

\footnotetext{
${ }^{290}$ Recorde-se que, por ocasião da Emenda Constitucional $n^{\circ}$ 14/1996, essa redação foi alterada para: ensino fundamental, obrigatório e gratuito, assegurada, inclusive, sua oferta gratuita para todos os que a ele não tiveram acesso na idade própria. O objetivo, certamente, foi evidenciar a questão da gratuidade.

${ }^{291}$ Nesse sentido GARCIA, Emerson, O Direito à Educação... cit., PP. 179 a 184.

${ }^{292}$ Sobre o tema, v. BARCEllos, Ana Paula de, O Mínimo Existencial e Algumas Fundamentações: John Rawls, Michael Walzer e Robert Alexy, in TORRES, Ricardo Lobo (org.), Legitimação dos Direitos Humanos, Rio de Janeiro, Renovar, 2007, p. 109.
} 
Assim, pode-se sustentar que essa teria sido a intenção da Constituição Federal de 1988 em relação ao direito à educação: identificar no ensino fundamental o patamar mínimo de concretização que não poderia, sob nenhum argumento, ser negado. Certamente, com o mesmo propósito, o seu artigo 227 acrescenta a relevante imposição da prioridade absoluta à infância e à juventude. Conforme ensina GARCIA $^{293}$, esse dispositivo retira a discricionariedade do legislador e do administrador público no que se refere ao resguardo dos direitos da criança e do adolescente. Neste âmbito, toda a ponderação, inclusive orçamentária, já está feita aprioristicamente pelo texto constitucional.

Entretanto, o constituinte reformador, com a já citada Emenda Constitucional $\mathrm{n}^{\circ}$ 59/2009, ampliou a extensão da proteção constitucional. Evidentemente atendendo à demanda social representada por uma sociedade brasileira em desenvolvimento ${ }^{294}$, fez com que o inciso I do artigo 208 da Constituição Federal de 1988 passasse a declarar dever do poder público a garantia de educação básica obrigatória e gratuita dos 4 (quatro) aos 17 (dezessete) anos de idade, assegurada inclusive sua oferta gratuita para todos os que a ela não tiveram acesso na idade própria. Com isso, considerando-se que o $\S 1^{\circ}$ do dispositivo permaneceu inalterado, toda a educação básica, desde que o educando esteja no intervalo etário delimitado, passou a ter assento constitucional como direito público subjetivo.

Diante da reforma, ao menos dois questionamentos descortinam-se. O primeiro, mais evidente, refere-se à educação infantil: foi intenção do constituinte reformador excluir o direito de atendimento em creches ${ }^{295}$ da caracterização como direito público subjetivo? $\mathrm{O}$ segundo questionamento está oculto no corpo da própria Emenda Constitucional $\mathrm{n}^{\circ}$ 59/2009. Ele é ensejado pelo artigo $6^{\circ}$ da emenda, que estabelece: [o] disposto no inciso I do art. 208 da Constituição Federal deverá ser implementado progressivamente, até 2016, nos termos do Plano Nacional de Educação, com apoio técnico e financeiro da União. Assim cumpre investigar: teria o constituinte reformador atribuído eventual caráter programático ao direito à educação?

\footnotetext{
${ }^{293}$ Cf. GARCIA, Emerson, O Direito à Educação... cit., PP. 172.

${ }^{294}$ Tendência que já havia iniciado com a Emenda Constitucional no 53/2006, que, dentre outras medidas, transformou o Fundo de Manutenção e Desenvolvimento do Ensino Fundamental (FUNDEF) em Fundo de Manutenção e Desenvolvimento da Educação Básica (FUNDEB). O mecanismo dos fundos como critério de vinculação orçamentária de recursos para aplicação na manutenção e no desenvolvimento do ensino será brevemente explicado no item 3.1.3.

${ }^{295}$ Lembrando que, segundo o artigo 30 da Lei $n^{\circ}$ 9.394/1996 a educação infantil é oferecida em creches para crianças de até três anos de idade e em pré-escolas para crianças de quatro a cinco anos de idade.
} 
3.1.2.2. A extensão do direito subjetivo à educação anterior à Emenda Constitucional no 59/2009

A despeito do tratamento diferenciado ao ensino fundamental presente na Constituição Federal de 1988 até 2009, é de se notar que nas cortes brasileiras, sobretudo no Supremo Tribunal Federal e no Superior Tribunal de Justiça, o maior número de decisões é referente à efetivação do direito social à educação na modalidade educação infantil. Evidentemente, são todas decisões anteriores à recente reforma trazida pela Emenda Constitucional n ${ }^{\circ}$ 59/2009.

Entretanto, na jurisprudência do Supremo Tribunal Federal, decisões garantindo a exigibilidade imediata do direito à educação surgem de modo expressivo apenas na segunda metade da primeira década deste século. No âmbito da corte constitucional, o precedente paradigmático cuja linha será seguida pelas decisões posteriores é o Agravo Regimental em recurso extraordinário $\mathrm{n}^{\circ}$ 410.715-5, de relatoria do Ministro Celso de Mello, decidido em 22 de novembro de $2005^{296}$.

Expondo o caso sinteticamente, deve-se afirmar que se trata de agravo regimental interposto contra decisão monocrática que havia dado provimento ao recurso extraordinário interposto pelo Ministério Público do Estado de São Paulo contra decisão do Tribunal de Justiça do Estado de São Paulo, em ação civil pública que tutelava o interesse

${ }^{296}$ Trata-se do primeiro acórdão que claramente determina a exigibilidade do direito à educação infantil. Mas foram proferidas decisões monocráticas com teor semelhante ao menos nas seguintes ocasiões: Recurso Extraordinário $n^{\circ}$ 411.518, Relator Ministro Marco Aurélio (03.03.2004), Recurso Extraordinário $n^{\circ} 431.773$, Relator Ministro Marco Aurélio (15.09.2004), Recurso Extraordinário no 402.024, Relator Ministro Carlos Velloso (05.10.2004), Recurso Extraordinário no 352.686, Relator Ministro Carlos Velloso (19.10.2004), Recurso Extraordinário no 411.332, Relator Ministro Carlos Velloso (19.10.2004), Recurso Extraordinário $n^{\circ}$ 398.722, Relator Ministro Carlos Velloso (19.10.2004), Recurso Extraordinário no 443.158, Relator Ministro Carlos Velloso (21.03.2005), e Recurso Extraordinário $\mathrm{n}^{\circ}$ 410.715, Relator Ministro Celso de Mello (27.10.2005). Todavia, podem-se citar decisões anteriores que, tangenciando o tema do direito à educação, negavam a justiciabilidade direta a algumas normas constitucionais. No Agravo Regimental em Recurso Extraordinário no 241.757, sobre o artigo 211, § $2^{\circ}$ da Constituição Federal de 1988 (atuação prioritária dos Municípios no ensino fundamental e na educação infantil), assim decidiu o Ministro Néri da Silveira: “[n]ão há dúvida nenhuma de que essas disposições postas na Constituição [relacionadas ao direito à educação] têm um sentido social de extraordinária abrangência. $O$ constituinte inseriu-as num avanço significativo neste plano. Mas, parece-me que o mandado de segurança não é, de fato, a via adequada para a fruição desses direitos contemplados no texto constitucional. Não tenho essas normas, desde logo, como autoaplicáveis. Penso que elas possuem um conteúdo predominantemente programático e dependeriam de procedimentos de integração" in Brasil, Supremo Tribunal Federal, Agravo Regimental no Recurso Extraordinário $\mathrm{n}^{\circ}$ 241.757, Relator Ministro Maurício Corrêa, DJ 24.04.2001. Outro exemplo é o Recurso Extraordinário $\mathrm{n}^{\circ}$ 401.880, decidido monocraticamente pelo relator em 27 de agosto de 2004, de cuja decisão extrai-se: “[o] preceito inscrito no artigo $211, \S 2^{\circ}$, da Constituição - 'Os Municípios atuarão prioritariamente no ensino fundamental e pré-escolar' - é norma programática que encontra sua concretização por meio de leis que visem implementar as políticas públicas" in BRASIL, SUPREMO TRIBUNAL FEDERAL, Recurso Extraordinário $n^{\circ}$ 401.880, Relator Ministro Eros Grau, DJ 28.09.2004. 
de menor ${ }^{297}$, proposta contra o Município de Santo André. A ação ministerial objetivava a matrícula de criança em creche municipal (educação infantil). Na segunda instância, por meio de acórdão em apelação confirmado por embargos infringentes, o pleito do Ministério Público paulista foi improvido. No recurso extraordinário contra o improvimento em segundo grau, o parquet sustentou a ofensa aos artigos 208, inciso IV (dever do poder público de prover a educação infantil), e $211, \S 2^{\circ}$ (exigência de atuação prioritária da municipalidade no ensino fundamental e na educação infantil). $O$ recurso extraordinário, decidido monocraticamente, foi provido. Insurgiu-se a municipalidade por meio de agravo regimental, ao qual a Segunda Turma do Supremo Tribunal Federal negou provimento.

O caso, conforme advertiu o próprio ministro relator do acórdão, demonstrava a estrutura normativa do direito subjetivo: o direito de um sujeito ao qual se contrapõe um o dever de outro sujeito. Na lide estavam envolvidos os preceitos constitucionais que estabelecem, de um lado, o direito público subjetivo à educação e, de outro lado, o dever do poder público de prover a educação infantil àqueles em idade própria ${ }^{298}$.

Do acórdão extrai-se que o Supremo Tribunal Federal concebe o direito à educação como prerrogativa constitucional deferida a todos (artigo 205 da Constituição Federal de 1988) que se qualifica como um direito fundamental de cunho tipicamente social. Compreende a corte suprema, ainda, que dele decorre um dever de prestação positiva ao Estado, do qual este apenas se desincumbe quando cria condições objetivas que viabilizem aos titulares do direito à educação a efetiva fruição do sistema educacional, o que deve iniciar com o atendimento em creches e pré-escolas (artigo 208, inciso IV, da Constituição Federal). Este é o primeiro argumento do acórdão. Num grande esforço de síntese, poderse-ia recolher mais dois.

O segundo argumento essencial da decisão concerne à possibilidade de o Poder Judiciário determinar à Administração que realize as políticas públicas (prestações) voltadas à efetivação do direito à educação. Em seu voto, o Ministro relator reconhece que não constitui atribuição do Poder Judiciário a formulação de medidas concretas de

\footnotetext{
${ }^{297}$ Na origem (Tribunal de Justiça do Estado de São Paulo), os Embargos Infringentes 078.969.0/0-0002-000 corriam sob segredo de justiça.

298 Nos termos do relator: "a decisão agravada ajusta-se, com integral fidelidade, aos postulados constitucionais que informam, de um lado, o direito público subjetivo à educação e que impõem, de outro, ao Poder Público, notadamente ao Município (CF, art. $211, \S 2^{\circ}$ ), o dever jurídico-social de viabilizar, em favor das 'crianças de zero a seis anos de idade' (CF, art. 208, IV), o efetivo acesso e atendimento em creches e unidades de pré-escola" in Brasil, Supremo Tribunal Federal, Agravo Regimental no Recurso Extraordinário n 410.715, Relator Ministro Celso de Mello, DJ 03.02.2006, p. 3.
} 
efetivação de direitos sociais, sendo esta uma função própria do Poder Legislativo e do Poder Executivo. Mas, o órgão jurisdicional deverá assumir excepcionalmente essa atribuição se as instituições públicas originalmente encarregadas "descumprirem os encargos político-jurídicos que sobre el[a]s incidem em caráter mandatório"299, assim comprometendo a eficácia de direitos constitucionalmente assegurados.

No âmbito do direito à educação a viabilidade dessa atuação excepcional do Poder Judiciário é ainda mais clara, tendo em vista que a Constituição Federal de 1988 dedica diversos dispositivos a delinear quais são, especificadamente, as ações esperadas do poder público. Por essa razão, segundo consta do acórdão, o “objetivo perseguido pelo legislador constituinte, em tema de educação infantil (...) traduz meta cuja não-realização qualificarse-á como uma censurável situação de inconstitucionalidade por omissão imputável ao Poder Público" ${ }^{, 300 .}$

No terceiro argumento o Supremo Tribunal Federal admite a relevância da objeção que opõe o alto custo dos direitos sociais ao caráter finito dos recursos públicos, muitas vezes referida por reserva do possível. No entanto, a decisão é incisiva no sentido de que a alegação da incapacidade econômico-financeira somente é admissível como razão de julgamento se for comprovada objetivamente. De fato, provada a inexistência de recursos, não seria razoável exigir-se da Administração a imediata efetivação do direito social à educação, fosse em creches e pré-escolas ou em instituições escolares de ensino fundamental.

Porém, segundo a Corte, a prova da reserva do possível dever ser cabal. Não se apresenta lícito ao Estado, "em tal hipótese, criar obstáculo artificial que revele - a partir de indevida manipulação de sua atividade financeira e/ou político-administrativa - o ilegítimo, arbitrário e censurável propósito de fraudar, de frustrar e de inviabilizar o estabelecimento e a preservação, em favor da pessoa e dos cidadãos, de condições materiais mínimas de existência" ${ }^{, 301}$. Tampouco se trata de tese que possa fundamentar a defesa de um eventual espaço de discricionariedade administrativa, livre da interferência jurisdicional. Quanto ao direito à educação, especialmente a educação infantil, a decisão ora comentada contém dois elementos principais para essa conclusão: a mencionada alta densidade normativa

\footnotetext{
299 Brasil, SUPREmo Tribunal Federal, Agravo Regimental no Recurso Extraordinário n ${ }^{\circ} 410.715$, Relator Ministro Celso de Mello, DJ 03.02.2006, pp. 9 e 10.

300 BRASIL, SuPREMo TRIBUNAL Federal, Agravo Regimental no Recurso Extraordinário $n^{\circ} 410.715$, Relator Ministro Celso de Mello, DJ 03.02.2006, pp. 6 e 7.

${ }^{301}$ BRASIL, SuPREMo TRIBUnal Federal, Agravo Regimental no Recurso Extraordinário $n^{\circ} 410.715$, Relator Ministro Celso de Mello, DJ 03.02.2006, p. 11.
} 
constitucional acerca da matéria e a prioridade absoluta dos direitos da criança e do adolescente reconhecida pelo artigo 227 Constituição Federal de $1988^{302}$.

Com isso, a decisão afastou o argumento defensivo do Município paulista, de a imposição judicial à municipalidade de manutenção de creches e pré-escolas em número suficiente para atender a toda a demanda de crianças em idade própria constituiria ingerência indevida do Poder Judiciário no poder Executivo, vulnerando, assim, a discricionariedade administrativa e a separação de poderes (artigo $2^{\circ}$ da Constituição Federal de 1988), bem como a exigência de vinculações orçamentárias específicas para as despesas municipais.

Afastadas tais defesas, o Supremo Tribunal Federal, nesse acórdão paradigmático, reconheceu que é dever estatal, notadamente do Município, passível de ser exigido do poder público pela via judicial, o fornecimento de educação em creches e pré-escolas às crianças de zero a cinco anos de idade (inciso IV do artigo 208 da Constituição Federal de 1988).

Deve-se registrar que esses argumentos mostraram-se igualmente superados em diversas outras decisões do Supremo Tribunal Federal, bem como do Superior Tribunal de Justiça e do Tribunal de Justiça do Estado de São Paulo.

No Supremo Tribunal Federal, numa das primeiras decisões representativas dessa tendência garantista acerca do direito à educação, afirmou o Ministro Marco Aurélio: “[c]onforme preceitua o artigo 208, inciso IV, da Carta Federal, consubstancia dever do Estado a educação, garantindo o atendimento em creche e pré-escola às crianças de zero a seis anos de idade [decisão anterior à Emenda Constitucional n ${ }^{\circ}$ 53/2006]. O Estado União, Estados propriamente ditos, ou seja, unidades federadas, e Municípios - deve aparelhar-se para a observância irrestrita dos ditames constitucionais, não cabendo tergiversar mediante escusas relacionadas com a deficiência de caixa. Eis a enorme carga tributária suportada no Brasil a contrariar essa eterna lengalenga"303.

Assim também a Ministra Cármen Lúcia: "[e]xsurge, nítido, o direito constitucionalmente assegurado ao menor (art. 208, inc. IV) (...). De se enfatizar que a educação compõe o mínimo existencial, de atendimento estritamente obrigatório pelo

\footnotetext{
${ }^{302}$ Nesse sentido, a alínea $d$ do parágrafo único do artigo $4^{\circ}$ da Lei $n^{\circ} 8.069 / 1990$ é precisa: Art. $4^{\circ}$ (...) Parágrafo único. A garantia de prioridade compreende (...) d - destinação privilegiada de recursos públicos nas áreas relacionadas com a proteção à infância e à juventude.

${ }^{303}$ BRASIL, SUPREMO TRIBUNAL FEDERAL, Recurso Extraordinário nº 431.773 (Decisão Monocrática), Relator Ministro Marco Aurélio, DJ 22.10.2004.
} 
Poder Público, dele não podendo se eximir qualquer das entidades que exercem as funções estatais" ${ }^{304}$.

Confira-se, ainda, o acórdão de relatoria da Ministra Ellen Gracie, proferido por unanimidade na Segunda Turma, cuja ementa afirma: "1. A educação infantil é prerrogativa constitucional indisponível, impondo ao Estado a obrigação de criar condições objetivas que possibilitem o efetivo acesso a creches e unidades pré-escolares. 2. É possível ao Poder Judiciário determinar a implementação pelo Estado, quando inadimplente, de políticas públicas constitucionalmente previstas, sem que haja ingerência em questão que envolve o poder discricionário do Poder Executivo"305.

No Superior Tribunal de Justiça, exemplificativamente, o mesmo teor de decisão pode ser verificado no Recurso Especial 790.175. De relatoria para acórdão do Ministro Luis Fux, consta da ementa do julgado: “[o] direito constitucional à creche extensivo aos menores de zero a seis anos é consagrado em norma constitucional reproduzida no art. 54 do Estatuto da Criança e do Adolescente (...). Consagrado por um lado o dever do Estado, revela-se, pelo outro ângulo, o direito subjetivo da criança. Consectariamente, em função do princípio da inafastabilidade da jurisdição consagrado constitucionalmente, a todo direito corresponde uma ação que o assegura, sendo certo que todas as crianças nas condições estipuladas pela lei encartam-se na esfera desse direito e podem exigi-lo em juízo. (...) A determinação judicial desse dever pelo Estado, não encerra suposta ingerência do judiciário na esfera da administração. Deveras, não há discricionariedade do administrador frente aos direitos consagrados, quiçá constitucionalmente. Nesse campo a atividade é vinculada sem admissão de qualquer exegese que vise afastar a garantia pétrea"306.

Como se percebe, ao decidir sobre o direito à educação infantil, além do suporte constitucional, o Superior Tribunal de Justiça fundamenta-se na legislação ordinária, notadamente da Lei no 8.069/1990 (Estatuto da Criança e do Adolescente). Assim também faz o Tribunal de Justiça do Estado de São Paulo.

Resumidamente, pode-se afirmar que, quanto à legislação infraconstitucional, o Tribunal paulista embasa suas decisões principalmente nos artigos 53, inciso V, 54, inciso

\footnotetext{
304 Brasil, SuPRemo Tribunal Federal, Agravo de Instrumento nº 431.773 (Decisão Monocrática), Relatora Ministra Cármen Lúcia, DJ 15.05.2007.

${ }^{305}$ BRAsil, SuPREMo TRIBunal Federal, Agravo Regimental em Recurso Extraordinário $\mathrm{n}^{\circ}$ 464.143, Relatora Ministra Ellen Gracie, DJ 19.02.2010.

${ }^{306}$ BRASIL, SUPERIOR TRIBUNAL DE JUSTIÇA, Recurso Especial n ${ }^{\circ} 790.175$, Relator para acórdão Ministro Luiz Fux, DJ 12.02.2007.
} 
IV, e 208, inciso III, todos da Lei $\mathrm{n}^{\circ}$ 8.069/1990. Como se sabe, nos dois primeiros dispositivos, respectivamente, fica assegurado à criança o acesso à escola pública e gratuita próxima de sua residência, e estabelecido o dever do Estado quanto ao atendimento em creche e pré-escola às crianças de zero a seis anos de idade. Por sua vez, o inciso III do artigo 208 faz referência à tutela jurisdicional do tema, nos seguintes termos:

Art. 208. Regem-se pelas disposições desta Lei as ações de responsabilidade por ofensa aos direitos assegurados à criança e ao adolescente, referentes ao não oferecimento ou oferta irregular: (...)

III - de atendimento em creche e pré-escola às crianças de zero a seis anos de idade; [redação ainda não atualizada conforme a Emenda Constitucional nº 53/2006).

Com esses fundamentos, em diversas ocasiões o Tribunal de Justiça do Estado de São Paulo decidiu no sentido de que "do passeio por tais normas legais, a conclusão que fica é que a educação, como direito de todos, faz parte da categoria dos direitos indisponíveis, posto conjugado ao bem comum. Deste modo, há de ser atendido sem objeções pelo Poder Público"307.

No julgamento da Apelação Cível n 362.019.5/6-00, a mesma Corte estadual afirmou ser "indiscutível a obrigação da Municipalidade em garantir vaga em creche ou em pré-escola para tais crianças, bem como para qualquer outra criança que lá resida. Se os pais têm obrigação em matricular a criança na creche ou pré-escola, dependendo da idade e da situação, a Municipalidade tem obrigação em manter vagas e oportunidades, inclusive procedendo a um censo no sentido de conhecer exatamente a necessidade, suprimindo-a. Deve, até mesmo, fornecer os insumos indispensáveis ao desenvolvimento do processo de ensino-aprendizagem",308.

Confira-se, ainda, o acórdão proferido na Apelação Cível com Revisão $\mathrm{n}^{\circ}$ 718.238.5/4-00: “[n]o que tange ao princípio da discricionariedade educacional alertado pela recorrente, não há que se falar em prerrogativa de escolha, no caso em apreço, exatamente porque ao Estado se impõe, por efeito de alta significação social de que reveste a educação infantil a obrigação constitucional (vinculação) de criar condições objetivas que possibilitem de maneira concreta, em favor dessas crianças, o efetivo acesso ao

307 Estado de São Paulo, Tribunal de JustiçA do Estado de São Paulo, Apelação Cível $n^{\circ} 742.938$ 5/0-00, Relator Desembargador Ronaldo Frigini, DJ 27.03.2009.

308 Estado de São Paulo, Tribunal de Justiça do Estado De São Paulo, Apelação Cível $n^{\circ}$ 362.019.5/6-00, Relator Desembargador Henrique Nelson Calandra, DJ 01.07.2008. 
atendimento em creches e unidades de pré-escola, sob pena de inaceitável omissão governamental, frustradora de prestação estatal que lhe impôs o próprio texto da Constituição Federal, de modo inarredável, sem qualquer tipo de faculdade a possibilitar o ingresso ou não desses menores em creches mantidas pelo Poder Público. O art. 227 da referida Carta é uma super norma jurídica de eficácia plena e imediata que impede a discricionariedade alegada pelo ente público para possibilitar ou não o ingresso da impetrante no serviço educacional" ${ }^{\text {309 }}$.

Interessante anotar um dos argumentos de defesa apresentados pelo Município de Jundiaí em apelação ${ }^{310}$ contra sentença que assegurava a matrícula do autor em unidade de educação infantil próxima de sua residência. Em resumo, alegou que só existiria direito subjetivo público quanto ao ensino fundamental, tendo em vista o realce que, até então, a Constituição Federal de 1988 atribuía-lhe ao qualificá-lo como obrigatório e gratuito. Diante disso, sustentou que entre as duas prioridades que o $\S 2^{\circ}$ do artigo 211 atribuía ao Município (ensino fundamental e educação infantil), apenas o ensino fundamental configuraria um dever.

A tese da municipalidade está, por suas próprias razões, superada pela nova redação do inciso I do artigo 208 da Constituição Federal de 1988. Como já repetido algumas vezes neste trabalho, hoje toda a educação básica é obrigatória e gratuita para a faixa etária de quatro a dezessete anos, constituindo, assim, direito público subjetivo ( $\$ 1^{\circ}$ do artigo 208). Mas o argumento usado pela Desembargadora Maria Olívia Alves, relatora do acórdão, para afastá-lo é emblemático da disposição da jurisprudência paulista em efetivar o direito à educação na modalidade educação infantil, reconhecendo nele a natureza de direito subjetivo oponível ao poder público. A magistrada entendeu que "[o] fato de o legislador constitucional ter dado destaque à obrigatoriedade e gratuidade do ensino fundamental não pode possibilitar a interpretação de que, então, propiciar o ensino infantil não é tão obrigatório para o Estado. O destaque foi assim efetuado porque o ensino fundamental é obrigatório também para os pais, enquanto que o ensino infantil, para estes último é

309 Estado de São Paulo, Tribunal de Justiça do Estado De São Paulo, Apelação Cível $n^{\circ}$ 718.238.5/4-00, Relator Desembargador Guerrieri Rezende, DJ 03.03.2008. No mesmo sentido podem ser citadas as decisões proferidas no Recurso Ex-Oficio $\mathrm{n}^{\circ}$ 149.699-0/6-00, Relator Desembargador Luiz Tâmbara; no Recurso Ex-Ofício no 159.389-0/0-00, Relator Desembargador Luiz Tâmbara; na Apelação Cível com Revisão no 720.697-5/8-00, Relator Desembargador Corrêa Vianna; na Apelação Cível com Revisão no 737.349-5/0-00, Relator Desembargador Laerte Sampaio; entre muitos outros.

${ }^{310}$ Estado de SÃo Paulo, Tribunal de JustiçA do Estado DE SÃo PAUlo, Apelação Cível n ${ }^{\circ} 155.042$ 0/8-00, Relatora Desembargadora Maria Olívia Alves, DJ 12.03.2008. 
facultativo, o que não retira a obrigatoriedade imposta ao Estado de viabilizar o acesso ao ensino infantil àqueles que desejem e necessitem desse atendimento" ${ }^{311}$.

A partir das decisões citadas conclui-se que a jurisprudência do Supremo Tribunal Federal, do Superior Tribunal de Justiça e do Tribunal de Justiça do Estado de São Paulo foi uníssona em reconhecer a existência de um poder jurídico do indivíduo de exigir do poder público a prestação da educação infantil. Em outras palavras, se entenderam ser possível ao particular valer-se das medidas judiciais cabíveis para exigir que o dever correspondente seja cumprido, esses órgãos jurisdicionais reconheceram o direito subjetivo à educação infantil. Esse caráter, aliás, como foi ressaltado, sempre esteve presente nos artigos 53, inciso V, 54, inciso IV, e 208, inciso III, da Lei $\mathrm{n}^{\circ}$ 8.069/1990. E vale ressaltar que lei e jurisprudência não fizeram diferença quanto à educação infantil que constitui direito subjetivo público ser oferecida em creches ou em pré-escolas.

Poderia a Emenda Constitucional n $n^{\circ} 59 / 2009$, ao estender a disposição expressa do $\S 1^{\circ}$ do artigo 208 da Constituição Federal de 1988 (o acesso ao ensino obrigatório $e$ gratuito é direito público subjetivo) à educação básica entre os quatro e os dezessete anos, ter retirado a qualidade de direito subjetivo do atendimento de crianças em creches (forma da educação infantil para crianças de zero a três anos)? Entende-se que não. O tema é afeto à proibição do retrocesso social.

Corolário imediato do princípio da segurança jurídica, previsto no caput do artigo $5^{\circ}$ da Constituição Federal, a vedação ao retrocesso é tratada na doutrina como um dos elementos essenciais à realização de um autêntico Estado de Direito. Isso porque, sem uma efetiva proteção à confiança na ordem jurídica, mesmo o governo das leis é capaz de expor os cidadãos às mais diferentes perversidades ${ }^{312}$.

Não se trata propriamente de uma proteção em face de medidas retroativas, já que não se cogita de alcançar o direito adquirido, o ato jurídico perfeito ou a coisa julgada, tampouco as demais posições consagradas pelo constituinte originário como sendo limites materiais à reforma constitucional ${ }^{313}$. Trata-se da uma proteção mais ampla, em face de

\footnotetext{
311 Estado de São Paulo, Tribunal de Justiça do Estado de São Paulo, Apelação Cível n ${ }^{\circ} 155.042-$ 0/8-00, Relatora Desembargadora Maria Olívia Alves, DJ 12.03.2008, PP. 6 e 7.

${ }^{312}$ SARLET, Ingo Wolfgang, A Eficácia do Direito Fundamental à Segurança Jurídica: Dignidade da Pessoa Humana, Direitos Fundamentais e Proibição do Retrocesso Social no Direito Constitucional Brasileiro, in Arquivos de Direitos Humanos, n. 6, 2006, p. 104.

${ }^{313}$ Acerca do tema, cf. SARLET, Ingo Wolfgang, A Problemática dos Fundamentais Sociais como Limites Materiais ao Poder de Reforma da Constituição, in Direitos Fundamentais Sociais: Estudos de Direito Constitucional, Internacional e Comparado, Rio de Janeiro, Renovar, 2003. O autor, partindo da premissa amplamente aceita na doutrina de que as cláusulas pétreas expressamente previstas na Constituição não
} 
qualquer modalidade de supressão ou redução das conquistas sociais, ainda que operada exclusivamente no plano infraconstitucional ${ }^{314}$. O princípio da vedação ao retrocesso traz à luz o questionamento acerca do grau de "blindagem" - se efetivamente existente - dos direitos sociais em face de restrições ou até mesmo supressões pelo legislador ordinário.

Citando CANotilho, SARLet explica que, uma vez concretizado na seara infraconstitucional, o direito social assume, ao mesmo tempo, a condição de um direito subjetivo a certa prestação estatal e de uma garantia institucional, deixando de pertencer à esfera de plena disponibilidade do legislador. Rebatendo a crítica de que o grau de indefinição constitucional acerca do conteúdo dos direitos sociais ensejaria ampla liberdade de atuação na esfera infraconstitucional (podendo o legislador até mesmo voltar atrás nas suas decisões), o autor assevera que a outorga ao legislador do poder de dispor livremente acerca do conteúdo essencial dos direitos sociais equivaleria a subtrair às normas constitucionais a sua eficácia jurídica. Isso porque o cumprimento do comando constitucional que consagra um direito social acaba por se confundir com a proibição de destruir a situação jurídica instaurada pelo legislador ${ }^{315}$. Em última análise, o direito social reconhecido pelo legislador é assegurado pela própria Constituição ${ }^{316}$.

SARLET, que entre nós tratou do tema com profundidade, enumera diversas premissas pelas quais se conclui que o princípio da vedação ao retrocesso encontra guarida no direito constitucional brasileiro. Menciona, por exemplo, que o Estado democrático e social de Direito impõe um patamar mínimo de segurança jurídica, que necessariamente envolve alguma proteção em face de atos de cunho retrocessivo. Explica, ainda, que a negativa de reconhecimento ao princípio da proibição do retrocesso significaria admitir que o legislador ordinário, a despeito de se encontrar vinculado às normas constitucionais, dispõe do poder de tomar livremente suas decisões, ainda que em desrespeito à vontade do Constituinte. Nesse ponto, citando a lição de BARROSO, SARLET conclui que a consagração da vedação ao retrocesso acaba por impedir a frustração da efetividade constitucional, uma

excluem outros limites materiais implícitos, expõe os diversos entendimentos acerca da extensão desses limites implícitos e conclui que "implícitos (...) ou não, os direitos sociais estão sujeitos à mesma proteção contra reformas constitucionais, na condição de limites materiais, que os demais conteúdos essenciais da Constituição" (op. cit., pp. 374-375).

${ }^{314}$ SARLET, Ingo Wolfgang, A Eficácia do Direito Fundamental à Segurança Jurídica... cit., pp. 114 e 115.

315 SARLET, Ingo Wolfgang, A Eficácia do Direito Fundamental à Segurança Jurídica... cit., pp. 121-122 e 126-128. Neste último ponto, o autor se vale da lição de JORGE MIRANDA, deixando claro, porém, que o constitucionalista português admite apenas uma proibição relativa de retrocesso.

${ }^{316}$ Nesse sentido, poder-se-ia afirmar que o reconhecimento de um direito social pelo legislador ordinário nada mais é do que a explicitação de um daqueles direitos e garantias decorrentes do regime e dos princípios adotados pela Constituição, na forma prevista em seu artigo $5^{\circ}, \S 2^{\circ}$ ("Os direitos e garantias expressos nesta Constituição não excluem outros decorrentes do regime e dos princípios por ela adotados, ou dos tratados internacionais em que a República Federativa do Brasil seja parte"). 
vez que, ao revogar um ato que deu concretude a uma norma constitucional ou viabilizou o exercício de um direito, o legislador estaria provocando um retorno à situação de omissão anterior. A lei, ao consagrar um direito social, em regulamentação de um mandamento constitucional, acaba por incorporá-lo ao patrimônio jurídico do cidadão, sem possibilidade de posterior supressão ${ }^{317}$.

O consenso doutrinário acerca do reconhecimento de uma proteção contra o retrocesso não se reflete na avaliação da amplitude dessa proteção. Tratando-se, porém, de um princípio - e não de uma regra - a análise de aplicabilidade da proibição do retrocesso não comporta solução baseada na lógica do tudo ou nada, não havendo que se cogitar, por exemplo, de uma vedação absoluta ao retrocesso em matéria de direitos sociais. Daí a necessidade de firmar alguns critérios capazes de viabilizar uma solução constitucionalmente adequada na aplicação do princípio. Nessa linha de raciocínio, SARLET propõe a remissão às idéias de núcleo essencial dos direitos sociais e de mínimo existencial. Não pode o legislador, uma vez concretizado um direito social na seara infraconstitucional, retroceder a ponto de afetar o cerne material da dignidade da pessoa ${ }^{318}$. Nessa linha já se manifestou o Ministro Celso de Mello, por ocasião do julgamento da Ação Direta de Inconstitucionalidade n 3128: “a cláusula que proíbe o retrocesso em matéria social traduz, no processo de sua concretização, verdadeira dimensão negativa pertinente aos direitos sociais de natureza prestacional, impedindo, em consequiência, que os níveis de concretização dessas prerrogativas, uma vez atingidos, venham a ser reduzidos ou suprimidos, exceto nas hipóteses (...) em que políticas compensatórias venham a ser implementadas pelas instâncias governamentais" 319 .

No texto original da Constituição Federal de 1988, como visto, apenas o acesso ao ensino fundamental foi declarado como direito público subjetivo. Todavia, de tudo que foi exposto, é forçoso concluir que a legislação infraconstitucional brasileira, principalmente nos artigos 53, inciso V, 54, inciso IV, e 208, inciso III, todos da Lei $n^{\circ}$ 8.069/1990, inaugurou as estruturas para o mesmo reconhecimento em relação à educação infantil já em 1990. Assim também se assentou na jurisprudência, em que pese o pronunciamento do caráter de direito subjetivo da educação infantil (creche e pré-escola) nos órgãos jurisdicionais só ter se iniciado em torno de uma década depois.

\footnotetext{
${ }^{317}$ SARLET, Ingo Wolfgang, A Eficácia do Direito Fundamental à Segurança Jurídica... cit., pp. 128 a 131. ${ }^{318}$ SARLET, Ingo Wolfgang, A Eficácia do Direito Fundamental à Segurança Jurídica... cit., pp. 134 a 137. ${ }^{319}$ BRAsil, SUPREMO TRIBUNAL FEDERAL, Ação Direta de Inconstitucionalidade $n^{\circ} 3128$, Relatora Ministra Ellen Gracie, DJ 18.02.2005.
} 
O Poder Judiciário não fez diferença entre o atendimento em creche e o atendimento em pré-escola ao reconhecer o direito subjetivo à educação infantil. Também não o fez o legislador do Estatuto da Criança e do Adolescente (Lei $n^{\circ}$ 8.069/90). Entende-

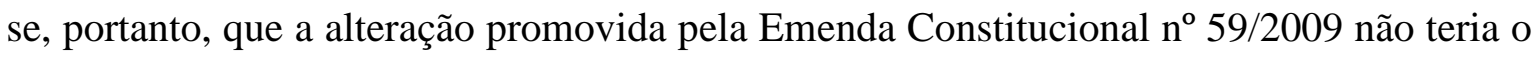
condão de retirar o nível alcançado de efetivação do direito social à educação quanto ao atendimento em creches para crianças de zero a três anos (artigo 30, inciso I, da Lei $\mathrm{n}^{\circ}$ 9.394/1996). Esta modalidade do direito à educação foi, há muito tempo, via legislador e juiz, identificada como elemento essencial do direito, decorrente, portanto, da noção de dignidade humana partilhada pela sociedade brasileira ${ }^{320}$.

$\mathrm{O}$ mesmo argumento responde o segundo questionamento apresentado ao final do item 3.1.2.1: a previsão pelo artigo $6^{\circ}$ da Emenda Constitucional $n^{\circ} 59 / 2009$ de que a obrigatoriedade e a gratuidade da educação básica, agora integralmente qualificada como direito público subjetivo, será implementada progressivamente, até 2016, nos termos do Plano Nacional de Educação, com apoio técnico e financeiro da União, teria determinado eventual caráter programático ao direito à educação?

Não em relação às posições de efetivação já alcançadas. Ensino fundamental e educação infantil (em creches ou em pré-escolas) permanecem direta e imediatamente exigíveis do poder público através das medidas judiciais cabíveis.

No entanto, cumpre anotar um problema: o ensino médio alçará a qualidade de direito público subjetivo apenas em 2016, ou se trata de modalidade do direito à educação acionável desde logo?

O inciso II do artigo 208 da Constituição Federal de 1988, mesmo após a Emenda Constitucional $\mathrm{n}^{\circ}$ 59/2009, dispõe ser dever do Estado a progressiva universalização do ensino médio gratuito. Por sua vez, o inciso II do artigo 54 da Lei $\mathrm{n}^{\circ}$ 8.069/1990 determina que constitui dever do Estado assegurar à criança e ao adolescente a progressiva extensão da obrigatoriedade e gratuidade ao ensino médio. O artigo 208 do mesmo diploma, utilizado pelos tribunais para fundamentar a acionabilidade do direito à educação infantil, não faz nenhuma referência expressa ao ensino médio.

O caráter de direito subjetivo do ensino médio, como passível de ser exigido judicialmente do poder público, nunca foi claro. Na doutrina, GARCIA fez essa ressalva de modo bastante claro: “[t]ratando-se de outros níveis de educação que não aqueles previstos

\footnotetext{
${ }^{320}$ A proibição do retrocesso social também afasta eventual alegação de que a introdução do inciso X no artigo $4^{\circ}$ da Lei $n^{\circ} 9.394 / 1996$, pela Lei $n^{\circ} 11.700 / 2008$, teria restringido a acionabilidade do direito à vaga em educação infantil às crianças a partir de quatro anos de idade.
} 
no art. 208, § $1^{\text {o }}$, da Constituição da República e no art. 208 da Lei $n^{\circ}$ 8.069/90, a exigibilidade de sua implementação dependerá do concurso de uma complexa rede de circunstâncias fáticas e jurídicas"321.

Objetivamente, portanto, não haveria, a princípio, nada no ordenamento que impedisse a submissão da exigibilidade do acesso ao ensino médio à progressiva implementação até o ano de 2016. Essa afirmação, porém, admite uma objeção, segundo a qual se poderia identificar uma situação jurídica instaurada pelo legislador que não poderia ser desfeita pelo legislador (proibição do retrocesso).

Trata-se alteração que a Lei $\mathrm{n}^{\circ} 12.061$, de 27 de outubro de 2009, introduziu no inciso II do artigo $4^{\circ}$ da Lei $n^{\circ} 9.394 / 1996$. Em sua redação original, esse dispositivo determinava ser dever do Estado com a educação escolar pública a progressiva extensão da obrigatoriedade e gratuidade ao ensino médio. A nova redação buscou atribuir noção de imediatismo ao dever do poder público, suprimindo do inciso a expressão progressiva extensão.

Assim, na nova redação do inciso II do artigo $4^{\circ}$ da Lei $n^{\circ} 9.394 / 1996$ passou a constar que o dever do Estado com educação escolar pública será efetivado mediante a garantia de, simplesmente, universalização do ensino médio gratuito. Considerando-se que a Emenda Constitucional no 59/2009 (11.11.2009) é posterior à alteração surge o questionamento sobre a validade de se subordinar temporalmente a exigibilidade dessa universalização ao ano de 2016.

Neste trabalho, entende-se que esse condicionamento é válido, tendo em vista que a Lei $n^{\circ} 12.061 / 2009$, embora já publicada, ainda não havia entrado em vigor quando da promulgação da Emenda Constitucional $n^{\circ} 59 / 2009$, o que somente ocorreria em $1^{\circ}$ de janeiro de 2010. O tema certamente deverá ser decidido pelos tribunais.

\subsubsection{Imposições legiferantes de organização: a estrutura do direito social à} educação.

Como visto acima a partir da lição de CANOTILHO ${ }^{322}$, na estrutura dos direitos sociais inserem-se imposições legiferantes. Trata-se de deveres que recaem sobre as

${ }^{321}$ GARCIA, Emerson, O Direito à Educação... cit., p 183. 
autoridades legislativas e governamentais no sentido de impor-lhes que atuem positivamente, criando condições materiais e institucionais para implementação desses direitos. Cada direito social, evidentemente, exigirá o desenvolvimento de uma estrutura legislativa e procedimental própria, voltada às suas peculiaridades.

No caso do direito à educação, a Constituição Federal de 1988 traz tais imposições de eficácia principalmente nos seguintes dispositivos: artigo 22, inciso XXIV, artigo 23, inciso V, artigo 24, inciso IX, artigo 34, inciso VII, alínea $e$, artigo 35, inciso III, artigo 40, $\S 5^{\circ}$, artigo 201, $\S 8^{\circ}$, artigos 211 a 214 , além dos artigos 60 e $76, \S 3^{\circ}$, do Ato das Disposições Constitucionais Transitórias. São todas normas que precedem, do ponto de vista lógico, a efetivação das prestações educacionais exigidas pelo direito à educação.

A competência legislativa acerca da atividade educacional está distribuída segundo os termos do artigo 22, inciso XXIV, e do artigo 24, inciso IX. No primeiro dispositivo, a Constituição Federal de 1988 determina ser da competência privativa da União legislar sobre diretrizes e bases da educação nacional. No segundo, de seu turno, estabelece competir concorrentemente à União, aos Estados e ao Distrito Federal legislar sobre educação, cultura, ensino e desporto.

Extrai-se do disposto nos $\S \S 1^{\circ}$ e $2^{\circ}$ do artigo 24 que na atividade legislativa concorrente sobre educação, a União tem competência para edição de normas gerais. Assim, Estados e Distrito Federal legislam apenas supletivamente, adequando e completando a legislação nacional editada pela União às peculiaridades dos respectivos sistemas de ensino. Segundo as disposições do artigo 30, caput, da Constituição Federal de 1988, e de seus incisos I e II, atribuição semelhante é conferida aos Municípios, sendo-lhes também possível suplementar as legislações nacional e estadual em atenção às necessidades do sistema de ensino local.

Quanto à distribuição de competências legislativas, existe, ainda, a previsão específica do artigo 214 da Constituição Federal de 1988. A norma determina que a lei estabeleça o plano nacional da educação, de duração decenal, cujo objetivo é articular $o$ sistema nacional de educação em regime de colaboração e definir diretrizes, objetivos, metas e estratégias de implementação para assegurar a manutenção e o desenvolvimento do ensino em seus diversos níveis, etapas e modalidades por meio de ações integradas dos poderes públicos das diferentes esferas federativas. Essas diretrizes, objetivos, metas e

${ }^{322}$ Canotilho, José Joaquim Gomes, Direito Constitucional ... cit., p. 466. 
estratégias deverão conduzir à erradicação do analfabetismo; universalização do atendimento escolar; melhoria da qualidade de ensino; formação para o trabalho; promoção humanística, científica e tecnológica do país; e ao estabelecimento de meta de aplicação de recursos públicos em educação como proporção do produto interno bruto. Evidentemente, diante do caráter nacional da lei a ser editada, trata-se de uma competência legislativa da União ${ }^{323}$. Entretanto, de acordo com o inciso I do artigo $9^{\circ}$ da Lei $n^{\circ}$ 9.394/1996, o plano nacional de educação deverá ser elaborado com a colaboração dos Estados, do Distrito Federal e dos Municípios.

A imposição de edição de um plano nacional de educação e a previsão de competência legislativa à União para edição de normas gerais a respeito do tema (sobre o que Estados, Distrito Federal e Municípios apenas complementam) evidenciam a intenção do constituinte de que houvesse um equilíbrio mínimo estabelecido nacionalmente quanto ao exercício da atividade educacional.

Por sua vez, o inciso V do artigo 23 atribui competência material genérica, em termos de provimento da educação, igualmente a todos os entes federativos brasileiros. Determina ser competência comum da União, dos Estados, do Distrito Federal e dos Municípios proporcionar os meios de acesso à cultura, à educação e à ciência. A atribuição genérica, entretanto, é detalhada no próprio texto constitucional por seu artigo 211.

O caput do dispositivo repete a preocupação de integração e composição nacional na área das políticas educacionais. Determina que a União, os Estados, o Distrito Federal e os Municípios organizarão em regime de colaboração seus sistemas de ensino. Seu $\S 4^{\circ}$ tem teor semelhante, prevendo que os entes federativos atuem em colaboração para assegurar a universalização do ensino obrigatório.

O detalhamento da competência material está mesmo nos $\S \S 1^{\circ}, 2^{\circ}$ e $3^{\circ}$ do artigo 211 da Constituição Federal de 1988. Vale registrar, todavia, que os dispositivos estabelecem prioridades quanto à prestação da educação, porém não exclusividades.

Segundo o $\S 3^{\circ}$, os Estados deverão atuar prioritariamente no ensino fundamental e no ensino médio. Já os Municípios, conforme o $\S 2^{\circ}$, deverão atuar prioritariamente no ensino fundamental e na educação infantil. E reza o $\S 1^{\circ}$ que a União, além de organizar o

\footnotetext{
${ }^{323}$ Atualmente está em vigor a Lei Federal no 10.172/2001. Editada em 9 de janeiro de 2001, a lei aproximase do final de seu decênio.
} 
sistema federal de ensino e financiar as instituições de ensino federais, exercerá função redistributiva e supletiva, de forma a garantir equalização de oportunidades educacionais e padrão mínimo de qualidade do ensino.

Portanto, a competência material da União é residual, supletiva, redistributiva e de coordenação $^{324}$. Na esfera infraconstitucional, esse caráter é reforçado e delimitado pelos incisos do artigo $9^{\circ}$ da Lei ${ }^{\circ}$ 9.394/1996.

Ainda em atenção ao caráter eminentemente prestacional do direito à educação, razão da afirmação de que prevalece sua dimensão de direito social, a Constituição Federal de 1988 definiu de antemão a origem do custeio das prestações educacionais. A isto se presta seu artigo $212^{325}$. Em linhas gerais, o texto constitucional vincula um percentual de aplicação anual em manutenção e desenvolvimento do ensino de dezoito por cento para a União e vinte e cinco por cento para os Estados, o Distrito Federal e os Municípios, calculados sobre a receita resultante de impostos, compreendida a proveniente de transferências (artigo 212, caput). Nesse montante não devem ser incluídos os gastos com programas suplementares de alimentação e assistência à saúde, que deverão ser custeados por meio das contribuições sociais e de outros recursos orçamentários $\left(\S 4^{\circ}\right)$. Ademais, como já mencionado, especificamente quanto à educação básica existe a previsão de fonte de custeio adicional: a contribuição do salário-educação $\left(\S 5^{\circ}\right)$, cujas cotas estaduais e municipais de arrecadação serão distribuídas proporcionalmente ao número de alunos matriculados na educação básica nas respectivas redes públicas de ensino $\left(\S 6^{\circ}\right)$.

O artigo 60 do Ato das Disposições Constitucionais Transitórias prevê uma subvinculação dos recursos vinculados à manutenção e ao desenvolvimento do ensino pelo artigo 212 da Constituição Federal de 1988 dos Estados, do Distrito Federal e dos Municípios. Esses entes federativos deverão destinar parte dos recursos vinculados pelo artigo 212 especificamente à manutenção e ao desenvolvimento da educação básica e à remuneração condigna dos trabalhadores da educação. Para esse fim, o artigo 60, inciso I, determina a criação de um Fundo de Manutenção e Desenvolvimento da Educação Básica e de Valorização dos Profissionais da Educação (FUNDEB) no âmbito de cada Estado e do

\footnotetext{
324 Nesse sentido, exemplificativamente, ver RANIERI, Nina Beatriz Stocco, Os Estados e o Direito à Educação na Constituição de 1988: Comentários Acerca da Jurisprudência do Supremo Tribunal Federal, in RANIERI, Nina Beatriz Stocco e RIGHETt, Sabine, Direito à Educação: Aspectos Constitucionais, São Paulo, EDUSP, 2009, pp. 39 a 59; e RIBEIRO, Lauro Luiz Gomes, Direito Educacional: Educação Básica e Federalismo, São Paulo, Quartier Latin, 2009, pp. 267 a 273.

${ }^{325}$ Por sua vez, o artigo 213 estabelece diretrizes sobre a destinação desses recursos.
} 
Distrito Federal $^{326}$. Instituído pela Emenda Constitucional $n^{\circ}$ 53, de 19 de dezembro de 2006, o modelo do FUNDEB deve ter vigência de quatorze anos a partir de sua promulgação. Assim como seu antecessor, o Fundo de Manutenção e Desenvolvimento do Ensino Fundamental e Valorização do Magistério (FUNDEF), o FUNDEB possui natureza contábil, sendo implementado, na realidade, pela abertura de conta única e específica junto ao Banco do Brasil ${ }^{327}$.

No âmbito de cada Estado e do Distrito Federal, o FUNDEB é composto por vinte por cento dos recursos obtidos com um conjunto de tributos que inclui: (i) parcela do Fundo de Participação dos Estados (artigo 157, inciso II, da Constituição Federal de 1988); (ii) parcela do Fundo de Participação dos municípios (artigo 158, incisos II, III); (iii) imposto sobre a circulação de mercadorias e serviços (ICMS); (iv) imposto sobre produtos industrializados proporcional às exportações (IPI-exportação); (v) desoneração das exportações prevista na Lei Complementar no 87/1996; (vi) imposto sobre a propriedade de veículos automotores (IPVA); (vii) imposto de transmissão causa mortis e doação de quaisquer bens ou direitos (ITCMD); (viii) imposto territorial rural (ITR).

A tudo isso somar-se-á uma complementação da União, sempre que no Estado ou no Distrito Federal o valor por aluno não alcançar o mínimo definido nacionalmente. $\mathrm{O}$ aporte de recursos pela União está especificado pelo inciso VII, alíneas $a$ a $d$, do artigo 60 do Ato das Disposições Constitucionais Transitórias. Note-se, apenas, que os recursos utilizados pela União para essa finalidade não poderão ter como origem a arrecadação do salário-educação (artigo 60, inciso V). O não cumprimento dessas regras pela autoridade federal competente importará crime de responsabilidade (artigo 60, inciso XI).

O artigo 60 em questão ainda faz outra vinculação de recursos para aplicação específica. Em seu inciso XII determina que proporção não inferior a sessenta por cento de cada fundo do FUNDEB deverá ser destinada ao pagamento dos profissionais do magistério da educação básica em efetivo exercício.

\footnotetext{
${ }^{326}$ Quanto a eventuais irregularidades na aplicação dos recursos dos fundos pelos Municípios, na jurisprudência do Supremo Tribunal Federal encontram-se algumas decisões indicando o posicionamento de que serão de atribuição do Ministério Público Federal sempre que consubstanciarem matéria criminal. Consistindo irregularidade cível a atribuição será do Ministério Público Federal ou do Ministério Público Estadual, conforme a origem dos recursos envolvidos (federais ou estaduais e municipais). Nesse sentido BRASIL, SUPREMO TRIBUNAL FEDERAL, Ação Cível Originária nº 1.237, Relator Ministro Eros Grau (Decisão Monocrática), DJ 02.02.2009.

${ }^{327}$ Nesse sentido a explicação do Tribunal de Contas do Estado de São Paulo in EsTADO DE SÃo PAULO, Tribunal de Contas, Manual Básico: Aplicação de Recursos no Ensino, São Paulo, 2007, p. 12, disponível em www.tce.sp.gov.br/arquivos/manuais-basicos/2007_aplicacao-de-recursos-no-ensino.pdf (acesso em 10.01.2010).
} 
Os artigos 34, inciso VII, alínea $e$, e 35, inciso III, da Constituição Federal de 1988, prevêem, respectivamente, hipótese de intervenção da União nos Estados, e dos Estados nos Municípios caso deixem de ser corretamente aplicados na manutenção e no desenvolvimento do ensino os recursos vinculados para esse fim pelo supramencionado artigo 212.

Cumpre registrar que, além da configuração de hipótese de intervenção na unidade federativa respectiva, a aplicação deficiente dos percentuais mínimos em educação legitima o Ministério Público a pleitear, através de ação civil pública, compensação dos recursos em exercício futuro. Nesse sentido é a jurisprudência do Supremo Tribunal Federal. No recurso extraordinário $\mathrm{n}^{\circ}$ 190.938, assim entendeu o Ministro Carlos Velloso: “[o] fato de o descumprimento do disposto no art. 212 da C.F. implicar intervenção estadual no Município não descaracterizaria a legitimação ativa do Ministério Público, tampouco tornaria juridicamente impossível o pedido formulado na ação civil pública, dado que a intervenção é ato político patológico, que deve ser evitado. A ação civil pública teria esse condão: evitaria a adoção desse ato político"328.

Ainda no tema do financiamento da prestação educacional, cumpre mencionar a previsão do $\S 3^{\circ}$ do artigo 76 do Ato das Disposições Constitucionais Transitórias, recentemente incluído pela Emenda Constitucional n ${ }^{\circ}$ 59/2009. O caput do artigo 76 desvincula de órgão, fundo ou despesa, vinte por cento da receita da União com impostos e contribuições até 31 de dezembro de 2011. Essa desvinculação sempre foi aplicada aos recursos destinados à manutenção e ao desenvolvimento do ensino. Porém, com a referida reforma, o $\S 3^{\circ}$ incluído passou a determinar que do valor de recursos federais apurado segundo a regra do artigo 212 da Constituição Federal de 1988 sejam desvinculados apenas doze e meio por cento em 2009, cinco por cento em 2010 e nada mais em 2011.

Registre-se, por fim, que também constitui norma constitucional de imposição procedimental, que pré-existe às prestações educacionais em si, a previsão de aposentadoria especial para professores da educação básica no regime próprio de previdência social dos servidores públicos (artigo 40, $\S 5^{\circ}$, da Constituição Federal de 1988), e de aposentadoria por tempo de contribuição reduzido de cinco anos para os

\footnotetext{
328 BRAsil, Supremo Tribunal Federal, Recurso Extraordinário n ${ }^{\circ}$ 190.938, Relator Ministro Carlos Velloso, DJ 22.05.2009 (julgado em 14.03.2006). Ver, no mesmo sentido, BRASIL, SUPREMO TRIBUNAL FEDERAL, Recurso Extraordinário $\mathrm{n}^{\circ}$ 352.352, Relatora Ministra Cármen Lúcia (Decisão Monocrática), DJ 25.11.2008; Brasil, Supremo TRIBUnAL FedERAL, Recurso Extraordinário $\mathrm{n}^{\circ}$ 364.864, Relatora Ministra Ellen Gracie (Decisão Monocrática), DJ 04.12.2009.
} 
professores da educação básica no regime geral de previdência social (artigo 201, § $8^{\circ}$, da Constituição Federal de 1988).

O $\S 2^{\circ}$ do artigo 67 da Lei $n^{\circ} 9.394 / 1996$, introduzido pela Lei $n^{\circ} 11.301$, de 10 de maio de 2006, determinou que, para os fins do $\S 5^{\circ}$ do artigo 40 e do $\S 8^{\circ}$ do artigo 201 da Constituição Federal, serão consideradas funções de magistério as exercidas por professores e especialistas em educação no desempenho de atividades educativas, quando exercidas em estabelecimento de educação básica em seus diversos níveis e modalidades, incluídas, além do exercício da docência, as de direção de unidade escolar e as de coordenação e assessoramento pedagógico.

A alteração legislativa teve sua constitucionalidade desafiada perante o Supremo Tribunal Federal pela Ação Direta de Inconstitucionalidade $n^{\circ}$ 3772. Todavia, a Corte Constitucional decidiu que a função de magistério não se circunscreve apenas ao trabalho em sala de aula, abrangendo também a preparação de aulas, a correção de provas, o atendimento aos pais e alunos, a coordenação e o assessoramento pedagógico e, ainda, a direção de unidade escolar.

Todavia, o Supremo Tribunal Federal entendeu que apenas professores de carreira são titulares do direito de aposentarem-se mediante critérios diferenciados. Assim, as funções de direção, coordenação e assessoramento pedagógico, para que se beneficiem das disposições do $\S 5^{\circ}$ do artigo 40 e do $\S 8^{\circ}$ do artigo 201 , deverão ser exercidas por professores de carreira. Portanto, conforme decidiu o Supremo Tribunal Federal, julgando parcialmente procedente a Ação Direta de Inconstitucionalidade, foram excluídos os especialistas em educação.

3.2. Dimensões de liberdade e coletiva do direito à educação: implicações recíprocas.

A abordagem detalhada do direito à educação em sua dimensão de direito social justifica-se por ser com esse caráter que o tema assume maior relevância na atualidade. Contudo, a verificação das exigências de concretização impostas pela cidadania impõe um exame, ainda que breve, das relações mútuas estabelecidas entre o direito à educação enquanto liberdade individual e enquanto direito da coletividade. 
Conforme já se comentou acima, a essência da dimensão não-prestacional do direito à educação encontra-se, principalmente, na não limitação do acesso à educação em função de qualidades pessoais (como religião, raça, origem etc.), na não imposição de religiões oficiais através do sistema de ensino, na ausência de definições de versões oficiais da história e na não restrição da pluralidade de conteúdos, bem como na garantia da liberdade de aprender e ensinar. $\mathrm{Na}$ ordem jurídica brasileira, esses temas encontram assento constitucional em diversos dispositivos da Constituição Federal de 1988.

Dentre os fundamentos do ensino estabelecidos pelo artigo 206, destacam-se: a liberdade de aprender, ensinar, pesquisar e divulgar o pensamento, a arte e o saber, estabelecida no inciso II; o pluralismo de idéias e concepções pedagógicas, e a coexistência de instituições públicas e privadas de ensino, estabelecidos no inciso III; e, a gestão democrática do ensino público, estabelecida no inciso VI.

No que diz respeito à abertura da atividade de ensino aos particulares há a regra específica do artigo 209, que expressamente determina sua livre exploração pela iniciativa privada, desde que atendidas as normas gerais de educação (inciso I) e observados os atos autorizativos e de avaliação de qualidade pelo poder público. Na mesma direção, mas priorizando a natureza assistencial da exploração particular do ensino, o artigo 213 da Constituição Federal de 1988 autoriza que recursos públicos de ensino sejam destinados a escolas comunitárias, confessionais ou filantrópicas, assim definidas em lei, que comprovem finalidade não lucrativa e apliquem seus excedentes financeiros em educação (inciso I), e que assegurem a destinação de seu patrimônio a outra escola comunitária, filantrópica ou confessional, ou ao poder público, no caso de encerramento de suas atividades (inciso II). Nesses dispositivos, a Constituição Federal de 1988 reforçou o padrão inicialmente apresentado no artigo 205, qual seja, o de trazer a sociedade como um todo para participar da atividade de ensino ${ }^{329}$.

\footnotetext{
${ }^{329}$ Esse é o ensinamento que se depreende do voto do Ministro Carlos Ayres Brito, ao julgar a Ação Direta de Inconstitucionalidade $n^{\circ}$ 3.330-1, ocasião em que afirmou: "a educação, notadamente a escolar ou formal, é direito social que a todos deve alcançar. Por isso mesmo, dever do Estado e uma de suas políticas públicas de primeiríssima prioridade. Mas uma política pública necessariamente imbricada com ações da sociedade civil, pois o fato é que também da Constituição figuram normas que: a) impõem às famílias deveres para com ela, educação (caput do art. 205); b) fazem do ensino uma atividade franqueada à iniciativa privada, desde que atendidas as condições de 'cumprimento das normas gerais da educação nacional', mais a 'autorização e avaliação de qualidade pelo Poder Público' (art. 209, coerentemente, aliás, com o princípio igualmente constitucional da 'coexistência de instituições públicas e privadas de ensino'); c) ainda admitem a prestação do ensino por 'escolas comunitárias, confessionais ou filantrópicas, definidas em lei', mediante o preenchimento de requisitos também expressamente indicados (incisos I e II do art. 213)" in BRASIL, Supremo Tribunal Federal, Ação Direta de Inconstitucionalidade n 3330-1, Ministro Relator Carlos Ayres Britto, DJ 09.04.2008 (voto do relator - ADI pende de julgamento), p. 20.
} 
Registre-se, adicionalmente, a presença de normas que buscam salvaguardar liberdades individuais específicas de determinados grupos. Nesse sentido, o $\S 1^{\circ}$ do artigo 210 da Constituição Federal de 1988 assegura o ensino religioso nos horários normais das escolas públicas de ensino fundamental, ainda que de matrícula facultativa. E o $\S 2^{\circ}$ do mesmo dispositivo, ao determinar a obrigatoriedade de o ensino fundamental ser ministrado em língua portuguesa, assegura às comunidades indígenas a utilização adicional de suas línguas maternas e de seus próprios processos de aprendizagem.

O mesmo teor de proteção de liberdade consta, ainda, do artigo 207 da Constituição Federal de 1988, que prevê a autonomia didático-científica, administrativa e de gestão financeira e patrimonial às universidades (caput) e às instituiçõos de pesquisa científica e tecnológica $\left(\S 2^{\circ}\right)$.

Porém, se por um lado o vínculo de pertencimento representado pela cidadania atribui uma imposição de concretização dessas liberdades em potencial, por outro, o mesmo pertencimento cria ao particular um dever de atender às expectativas da sociedade em relação a ele. Estas, evidentemente, estão voltadas à realização do bem comum. Tratase da dimensão coletiva do direito à educação. Isso significa que a sociedade como um todo tem interesse em que o direito à educação realize-se de uma determinada maneira, coletivamente definida, uma vez que perfaz um imperativo de desenvolvimento social. E a Constituição Federal de 1988 também procurou resguardar o direito à educação nessa sua dimensão transindividual.

Nesse contexto insere-se o disposto nos artigos 208, inciso I e $\S 3^{\circ}, 227$ e 228 , que juntos formam a base constitucional para a obrigatoriedade de ensino. Como já mencionado, após a Emenda Constitucional no 59/2009, o ensino obrigatório, que deve ser cursado em instituições escolares, corresponde à educação básica, para os educandos que estiverem na faixa etária de quatro a dezessete anos.

O mesmo caráter é verificado no artigo 210, caput, da Constituição Federal de 1988, ao prever que ao Estado cabe fixar conteúdos mínimos para o ensino fundamental, de modo a assegurar uma educação básica comum e o respeito aos valores culturais e artísticos, nacionais e regionais. Em verdade, o mesmo propósito de proteger o interesse da coletividade com a educação consta do $\S 2^{\circ}$ do dispositivo, quando impõe que o ensino fundamental seja sempre ministrado em língua portuguesa (ainda que línguas indígenas possam ser utilizadas paralelamente). 
O próprio controle do Estado sobre a atividade educacional privada, que por ele deve ser autorizada e fiscalizada em termos de sua qualidade e cumprimento das normas gerais de educação (incisos I e II do artigo 209 da Constituição Federal de 1988), é outro exemplo da expressão coletiva do direito à educação.

Certamente, a proteção constitucional concomitante a essas duas modalidades de interesse (individuais e coletivos) é fonte, ocasionalmente, de tensões cuja dissolução impõe-se ao legislador e à autoridade judiciária. Como ocorre em tantas outras situações relativas a direitos fundamentais, os dois elementos envolvidos, ou seja, as liberdades envolvidas na educação e os benefícios à coletividade que a atividade educacional traz apresentam-se ao regulamentador e ao aplicador das normas constitucionais como fundamentos de idêntico valor argumentativo. Legislador e juiz têm, então, a difícil função de ponderar, combinando os diferentes tipos de proteção, de modo a encontrar a solução mais razoável ${ }^{330}$.

Esquematicamente três temas podem representar a dificuldade dessa combinação, a saber: a questão do ensino religioso, o ensino obrigatório e o problema da inadimplência de mensalidades em instituições particulares de ensino.

\subsubsection{O ensino religioso no Brasil.}

No Brasil, a liberdade de crença é assegurada como direito fundamental pelo artigo $5^{\circ}$ da Constituição Federal de 1988, que determina ser inviolável a liberdade de consciência e de crença, sendo assegurado o livre exercício dos cultos religiosos e garantida, na forma da lei, a proteção aos locais de culto e a suas liturgias (inciso VI); bem como que ninguém será privado de direitos por motivo de crença religiosa ou de convicção filosófica ou política, salvo se as invocar para eximir-se de obrigação legal a todos imposta e recusar-se a cumprir prestação alternativa, fixada em lei (inciso VIII). A laicidade do Estado brasileiro, por sua vez, é proclamada no inciso I do artigo 19 da Carta constitucional: é vedado à União, aos Estados, ao Distrito Federal e aos Municípios

\footnotetext{
${ }^{330}$ Ponderação enquanto método de solução de aparentes contradições é entendida, neste contexto, no sentido que lhe dá SANCHÍs: “[p]onderar es, pues, buscar La mejor decisión (La mejor sentencia, por ejemplo) cuando en la argumentación concurren razones justificatorias conflictivas y del mismo valor" in SANCHÍs, Luis Pietro, Neoconstitucionalismo Y Ponderación Judicial, in CARBOnell, Miguel (org.), Neoconstitucionalismo(os), Madrid, Trotta, 2003, p. 137.
} 
estabelecer cultos religiosos ou igrejas, subvencioná-los, embaraçar-lhes o funcionamento ou manter com eles ou seus representantes relações de dependência ou aliança, ressalvada, na forma da lei, a colaboração de interesse público.

Entretanto, o texto constitucional assegura, como visto, a presença do ensino religioso como disciplina dos horários normais das escolas públicas de ensino fundamental ( $\$ 1^{\circ}$ do artigo 210). A matrícula na matéria, todavia, é facultativa. Deve-se registrar que essa facultatividade constitui norma de vinculação geral da educação nacional, devendo ser observada tanto na educação pública como na explorada pela iniciativa privada ${ }^{331}$.

O dilema inicial que a combinação desses enunciados normativos apresenta pode ser sintetizado na seguinte pergunta: há direito oponível ao poder público ao ensino religioso? Vale dizer: o ensino religioso insere-se no conteúdo prestacional devido pelo Estado em termos de direito à educação? A resposta a essas perguntas é de grande relevância uma vez que identifica o responsável pelo custeio desse oferecimento ${ }^{332}$.

A norma constitucional do $\S 1^{\circ}$ do artigo 210 da Constituição Federal de 1988 foi originalmente regulamentada pelo artigo 33 da Lei $n^{\circ}$ 9.394/1996 da seguinte forma:

Art. 33. O ensino religioso, de matrícula facultativa, constitui disciplina dos horários normais das escolas públicas de ensino fundamental, sendo oferecido, sem ônus para os cofres públicos, de acordo com as preferências manifestadas pelos alunos ou por seus responsáveis, em caráter:

I - confessional, de acordo com a opção religiosa do aluno ou do seu responsável, ministrado por professores ou orientadores religiosos preparados e credenciados pelas respectivas Igrejas ou entidades religiosas; ou

II - interconfessional, resultante de acordo entre as diversas entidades religiosas, que se responsabilizarão pela elaboração do respectivo programa. (não grifado no original)

Constata-se, assim, que a lei foi expressa em afastar o financiamento público. $\mathrm{O}$ Conselho Nacional de Educação ${ }^{333}$, por ocasião do Parecer n ${ }^{\circ} 05$, de 11 de março de 1997, entendeu, inclusive, que a ressalva expressa seria desnecessária. Isso porque, do contrário,

\footnotetext{
331 Nesse sentido CURY, Carlos Roberto Jamil, Ensino religioso na escola pública: o retorno de uma polêmica recorrente, in Revista Brasileira de Educação, n. 27, 2004, p. 185.

${ }^{332}$ Sobre o tema, ver XIMENES, Salomão Barros, O Ensino Religioso nas Escolas Públicas Brasileiras: do Direito à Liberdade de Crença e Culto ao Direito à Prestação Estatal Positiva, in RANIERI, Nina Beatriz Stocco e RigheTTI, Sabine, Direito à Educação: Aspectos Constitucionais, São Paulo, EDUSP, 2009, pp. 89 a 109.

${ }^{333}$ Esta Dissertação não se propôs a analisar os atos regulatórios dos órgãos do Poder Executivo acerca do direito à educação. A menção ao Conselho Nacional de Educação, órgão do Ministério da Educação, é excepcional e fundada na escassez de decisões jurisprudenciais sobre o tema.
} 
havendo financiamento pelo poder público, restaria violado o inciso I do artigo 19 da Constituição Federal de 1988, quando veda a subvenção a entidades religiosas. Na interpretação do órgão ministerial, o texto constitucional e a sua regulamentação pelo artigo 33 da Lei $\mathrm{n}^{\text {o }}$ 9.394/1996 seriam suficientemente atendidos com o cumprimento de duas obrigações pela escola: "1. Garantir a 'matrícula facultativa', o que supõe que a escola, em seu projeto pedagógico, ofereça com clareza aos alunos e pais quais são as opções disponibilizadas pelas igrejas, em caráter confessional ou interconfessional; 2. Deixar horário e instalações físicas vagas para que os representantes das igrejas os ocupem conforme sua proposta pedagógica, para os estudantes que demandarem o ensino religioso de sua opção, não o saber das religiões, que poderá ser ministrado por qualquer professor afeito a tal conteúdo, mas a prática assumida por um representante confessional ou interconfessional".

No entanto, pouco tempo após a aprovação deste parecer, a Lei n 9.475, de 22 de julho de 1997, alterou o artigo 33 da Lei $\mathrm{n}^{\circ}$ 9.394/1996, dele passando a constar a seguinte redação:

Art. 33. O ensino religioso, de matrícula facultativa, é parte integrante da formação básica do cidadão e constitui disciplina dos horários normais das escolas públicas de ensino fundamental, assegurado o respeito à diversidade religiosa do Brasil, vedadas quaisquer formas de proselitismo.

$\S 1^{\circ}$ Os sistemas de ensino regulamentarão os procedimentos para a definição dos conteúdos do ensino religioso e estabelecerão as normas para a habilitação e admissão dos professores.

$\S 2^{\circ}$ Os sistemas de ensino ouvirão entidade civil, constituída pelas diferentes denominações religiosas, para a definição dos conteúdos do ensino religioso.

Conforme salienta $\mathrm{CURY}^{334}$, a versão alterada (que permanece em vigor) não repete a vedação ao custeio público do ensino religioso. Ademais, aumentou a responsabilidade dos sistemas de ensino estaduais e municipais, atribuindo-lhes a função de estabelecer normas para habilitação e admissão dos professores, no que a sociedade civil deverá participar.

Teriam a supressão da vedação ao custeio público e o aumento das atribuições regulatórias do poder público transformado o ensino religioso em direito público subjetivo? A resposta tende a ser afirmativa. Retirado o expresso óbice legal, o único

\footnotetext{
${ }^{334}$ CURY, Carlos Roberto Jamil, Ensino religioso na escola pública: o retorno de uma polêmica recorrente, in Revista Brasileira de Educação, n. 27, 2004, p. 185
} 
argumento em sentido contrário refere-se à laicidade do Estado, nos termos do inciso I do artigo 19 da Constituição Federal de 1988. Todavia, do próprio texto constitucional extraem-se razões que fundamentam a conclusão afirmativa.

Primeiramente, mencione-se o artigo 213, caput, que permite a destinação de recursos públicos para escolas confessionais. Se a Carta constitucional admite o financiamento integral da educação ministrada em estabelecimento de caráter religioso, por que não admitiria o financiamento de uma disciplina quando esta for oferecida nas próprias instituições oficiais de ensino fundamental?

Em segundo lugar, quando o $§ 1^{\circ}$ do artigo 208 da Constituição Federal de 1988 estabelece o direito público subjetivo ao ensino obrigatório e gratuito, o faz em relação à integralidade da educação básica, sem excepcionar disciplinas. E exceções expressas, como devem ser as exceções a direitos fundamentais, não são encontradas em outra parte do ordenamento nacional.

Tudo indica, portanto, que é exigível do poder público o dever de prestar sob seu custeio, nas escolas de ensino fundamental, o ensino religioso. A fixação de seu conteúdo fica a cargo dos Conselhos municipais e estaduais de ensino, com a colaboração da sociedade civil, em atenção à pluralidade de orientações religiosas ${ }^{335}$.

\subsubsection{O ensino obrigatório (e conteúdos mínimos).}

A obrigatoriedade de matrícula e frequência na educação escolar (escolas autorizadas e fiscalizadas pelo poder público), hoje extensível até o ensino médio, constitui a forma mais expressiva de intervenção estatal na autonomia individual no contexto do direito à educação.

A base constitucional da obrigatoriedade encontra-se nos artigos 208 , inciso I e $\S$ 3, 227 e 228 da Constituição Federal de 1988, conforme registrado anteriormente. Do ponto de vista infraconstitucional, diversos outros dispositivos reforçam o caráter obrigatório da educação.

Segundo o outrora citado artigo 55 da Lei $\mathrm{n}^{\circ}$ 8.069/1990, pais e responsáveis têm a obrigações de matricular seus filhos ou pupilos na rede regular de ensino. O mesmo

\footnotetext{
${ }^{335}$ Nesse sentido o Parecer no 26/2007 da Câmara de Educação Básica do Conselho Nacional de Educação.
} 
diploma, em seu artigo 129, inciso $\mathrm{V}$, prevê que a obrigação de matrícula e de acompanhamento da frequiência e aproveitamento escolar do filho ou pupilo pode ser imposta ao pai ou responsável pelo Conselho Tutelar ou juiz de infância e juventude, em caso de eventual ameaça de descumprimento da educação obrigatória. Vale lembrar, ademais, que a conduta também é tipificada como crime no artigo 246 do Código Penal, comentado acima.

Por sua vez, o artigo $6^{\circ}$ da Lei $n^{\circ}$ 9.394/1996 também determina, de modo expresso, ser dever dos pais e responsáveis efetuar a matrícula dos menores, a partir dos seis anos de idade, no ensino fundamental. Considera-se que esta redação deve ser adaptada à nova redação do inciso I do artigo 208 da Carta constitucional. De modo que, na atualidade, o dever de matrícula existe a partir dos quatro anos de idade.

A Lei no 9.394/1996 também deixa claro que a frequiência à instituição de ensino também não é de livre opção do aluno em idade escolar. Faz isso nos incisos VII e VIII de seu artigo 12. Tais dispositivos impõem aos estabelecimentos de ensino (i) informar pai e mãe, conviventes ou não com seus filhos, e, se for o caso, os responsáveis legais, sobre a freqüencia e rendimento dos alunos, bem como sobre a execução da proposta pedagógica da escola; e (ii), notificar ao Conselho Tutelar do Município, ao juiz competente da Comarca e ao respectivo representante do Ministério Público a relação dos alunos que apresentem quantidade de faltas acima de cinqüenta por cento do percentual permitido.

Assim, o ordenamento pátrio limita fortemente a autonomia individual quanto à educação no trecho da vida que se estende dos quatro aos dezessete anos. Essa limitação, além de proibir a não-educação, proíbe também a educação ministrada exclusivamente no ambiente familiar (o que se costuma chamar de homeschooling, por influência norteamericana, onde representa movimento mais expressivo), bem como exclusivamente em instituições informais de ensino. Sem dúvida é uma medida que, embora restrinja a liberdade, promove a isonomia, uma vez que busca igualar as oportunidades de partida dos indivíduos, ao menos em certa medida (descontando-se os argumentos conjunturais acerca das diferenças de qualidade entre diferentes escolas).

O tema foi objeto de Mandado de Segurança julgado pelo Superior Tribunal de Justiça, no qual os impetrantes pleiteavam o reconhecimento de seu 'direito' a educar seus três filhos no recesso do lar, sem freqüência ao estabelecimento de ensino em que estavam matriculados, cuja atuação restringir-se-ia a aplicar as avaliações de praxe, conforme a série correspondente à faixa etária dos educandos. Por maioria de votos, foi denegada a 
segurança, tendo a Corte entendido que "inexiste previsão constitucional e legal, como reconhecido pelos impetrantes, que autorizem os pais a ministrarem aos filhos as disciplinas do ensino fundamental, no recesso do lar, sem controle do poder público quanto à freqüência no estabelecimento de ensino e ao total de horas letivas indispensáveis à aprovação do aluno" 336 .

Certamente, um dos principais fundamentos dessa forte intervenção na autonomia individual é precisado por CURY: trata-se de um imperativo de socialização, entendida como a integração do indivíduo na vida em coletividade.

$\mathrm{O}$ autor reconhece que a família somente pode ir até certo ponto. Ou seja, o convívio familiar, importantíssimo, é capaz de dar ao indivíduo apenas uma socialização primária, referente às primeiras diferenciações de si em relação ao outro, feitas pela criança no início da vida. Todavia, conforme o ser humano avança na infância e em direção à idade adulta, tem que assumir inúmeros papéis perante a sociedade, para os quais a família, sozinha, não consegue prepará-lo. Para tanto é necessária uma socialização secundária, desempenhada pela escola através da transmissão de conhecimentos técnicos e de valores socialmente partilhados. As claras palavras do autor são insubstituíveis: "[c]omo uma agência socializante, a instituição escolar propicia tanto a transmissão do acúmulo de conhecimentos por meio do desenvolvimento de capacidades cognoscitivas quanto a transmissão de normas, valores, atitudes relativas à vida social" 337 .

A obrigatoriedade da educação responde, então, a uma necessidade da cidadania enquanto fundamento do Estado (artigo $1^{\circ}$, inciso II, da Constituição Federal de 1988). O vínculo de pertencimento à sociedade estatal, que em termos jurídicos impõe uma exigência de concretização de direitos fundamentais, tem na educação escolar um de seus principais construtores. Nesse sentido, a obrigatoriedade torna-se ela própria uma exigência da cidadania, que o indivíduo deve satisfazer por pertencer e para pertencer. Esse teor pode ser observado nos votos vencedores do julgado do Superior Tribunal de Justiça acima citado.

Assim foi o voto do Relator, Ministro Francisco Peçanha Martins: “[o]s filhos não são dos pais, como pensam os Autores. São pessoas com direitos e deveres, cujas personalidades se devem forjar desde a adolescência em meio a iguais, no convívio social

${ }^{336}$ BRASIL, SUPERIOR TRIBUNAL DE JUSTIÇA, Mandado de Segurança n ${ }^{\circ}$ 7.407, Relator Ministro Francisco Peçanha Martins, DJ 21.03.2005, Ementa.

${ }^{337}$ CURY, Carlos Roberto Jamil, Educação escolar e educação no lar: espaços de uma polêmica, in Educação e Sociedade, v. 27, n. 96, 2009, p. 671. 
formador da cidadania". Por sua vez, em seu voto acompanhando o Relator, afirmou a Ministra Laurita Vaz: “[a] Escola, com diretrizes traçadas pelo Estado, refletindo a cultura e os interesses da sociedade que representa, é uma das Instituições mais importantes para firmar os pilares fundamentais, os princípios balizadores para a formação do indivíduo, do cidadão. E essa formação não se restringe aos aspectos formais de conteúdos previamente estabelecidos. É mais que isso. O ambiente escolar possibilita o convívio com o diferente, com o igual, com o parecido, com o desconhecido. Aprende-se o significado da palavra participação. O aluno não é um mero receptor passivo, ao revés, é provocado a interagir, a opinar, a concordar ou discordar. Aprende-se o significado da palavra cidadão, do que é cidadania".

Esses imperativos de formação coletiva, que buscam deixar os indivíduos com iguais condições para, a partir deste ponto de partida comum, enfrentarem a vida em sociedade, constituem outro elemento diferenciador do direito à educação em relação a outros direitos de cunho eminentemente social. Ao direito à educação não corresponde mero serviço público, a ser usufruído pelo cidadão à medida que o solicite. Ao direito à educação também corresponde uma obrigação imposta a seu titular (bem como àqueles que por ele se responsabilizem). E tanto a viabilização de condições de concretização do direito à educação pelo Estado como o dever de exercê-lo são decorrências necessárias da cidadania.

A mesma sorte de razões explica o regramento relativo ao controle de freqüência, à organização dos anos letivos e à fixação do conteúdo essencial da educação básica, constantes da Constituição Federal de 1988 e da Lei nº 9.394/1996.

Assim é que o inciso I do artigo 24 da Lei no 9.394/1996 determina que nos níveis de ensino fundamental e médio seja respeitada carga mínima anual de oitocentas horas, distribuídas em no mínimo duzentos dias letivos de efetivo trabalho escolar, excluído desse total o tempo reservado aos exames finais, quando houver. O inciso VI do mesmo artigo, por sua vez, exige a frequiência mínima de setenta e cinco por cento do total de horas letivas para aprovação. Ademais, especificamente quanto ao ensino fundamental, a Lei ainda impõe, em seu artigo 34, que deve ser observada uma jornada escolar que conte com pelo menos quatro horas de trabalho efetivo em sala de aula, sendo progressivamente ampliado o período de permanência na escola.

No mesmo contexto de intervenção à autonomia individual encontra-se a redação do caput do artigo 210 da Constituição Federal de 1988: serão fixados conteúdos mínimos 
para o ensino fundamental, de maneira a assegurar formação básica comum e respeito aos valores culturais e artísticos, nacionais e regionais.

Na esfera federal, a Lei $n^{\circ}$ 9.394/1996 conta com disposições no mesmo sentido, abrangendo também o ensino médio. O artigo 26, caput, desse diploma exige que os currículos do ensino fundamental e do ensino médio contem com uma base nacional comum, que poderá ser complementada pelos sistemas de ensino e estabelecimentos de ensino de acordo com as características regionais e locais.

Essa base nacional comum abrangerá necessariamente o estudo da língua portuguesa e da matemática, o conhecimento do mundo físico e natural e da realidade social e política, especialmente do Brasil (artigo 26, $\S 1^{\circ}$ ). Outros componentes obrigatórios correspondem ao ensino de arte (artigo $26, \S 2^{\circ}$ ) e à educação física (artigo 26 , $\left.\S 3^{\circ}\right)^{338}$. O estudo artístico deve observar, necessária mas não exclusivamente, o estudo da música (artigo 26, $\S 6^{\circ}$ ), e, a partir da quinta série, deve existir no currículo o ensino de pelo menos uma língua estrangeira (artigo $26, \S 5^{\circ}$ ). Ademais, tanto o ensino médio como o ensino fundamental deverão obrigatoriamente prover o estudo da história e da cultura afro-brasileira e indígena (artigo 26-A).

Especificamente quanto ao currículo do ensino fundamental, o $\S 5^{\circ}$ do artigo 32 da Lei $\mathrm{n}^{\circ} 9.394 / 1996$ exige a inclusão de conteúdo que trate dos direitos das crianças e dos adolescentes, com base nas previsões da Lei $\mathrm{n}^{\circ} 8.069 / 1990$, observada a produção e a distribuição de material didático adequado. Por sua vez, no ensino médio serão obrigatoriamente incluídas as disciplinas de Filosofia e Sociologia em todas as suas séries, conforme previsão do inciso IV do artigo 36 da Lei nº 9.394/1996.

As normas elencadas acima compõem, então, um patamar mínimo de formação (de conteúdo formal, quanto à forma do processo de ensino, e material, quanto aos ensinamentos em si) que é imposto ao cidadão, em detrimento de sua liberdade acerca da própria educação (ou de seus filhos e pupilos).

O rol evidentemente não esgota o tema, sendo certo que os sistemas de ensino estaduais e municipais detêm atribuição para complementá-lo. Porém é suficiente como

\footnotetext{
${ }^{338}$ Excepcionalmente, a educação física será facultativa nos seguintes termos: Art. 26. (...) § $3^{\circ}$ A educação física, integrada à proposta pedagógica da escola, é componente curricular obrigatório da educação básica, sendo sua prática facultativa ao aluno: I - que cumpra jornada de trabalho igual ou superior a seis horas; II maior de trinta anos de idade; III - que estiver prestando serviço militar inicial ou que, em situação similar, estiver obrigado à prática da educação física; IV - amparado pelo Decreto-Lei $\mathrm{n}^{\circ} 1.044$, de 21 de outubro de 1969 [tratamento excepcional para alunos portadores de afecções congênitas ou adquiridas, infecções, traumatismo ou outras condições mórbidas]; V - que tenha prole.
} 
argumento demonstrativo da tensão suscitada acima, qual seja, a existente entre o direito à educação em sua dimensão de liberdade e o direito à educação em sua dimensão coletiva (ligado ao bem comum), ambas igualmente decorrentes do vínculo da cidadania.

\subsubsection{A intervenção estatal na atividade educacional privada: a questão das} mensalidades em atraso.

A livre exploração da atividade educacional pelo setor privado está constitucionalmente assegurada pela conjugação dos artigos 170 e 209 da Constituição Federal de 1988, desde que, conforme a ressalva dos incisos I e II do último dispositivo, sejam respeitados os limites impostos pelas normas gerais da educação nacional e de autorização e avaliação de qualidade pelo poder público. A intervenção no setor está, portanto, igualmente prevista no texto constitucional. A justificativa dessa intervenção é, novamente, o interesse coletivo envolvido na educação.

Muitos temas exemplificariam a tensão supramencionada, a começar pela própria imperiosidade de atos autorizativos e de controle para o exercício da atividade de ensinar (ao menos quanto à educação escolar). Todavia, neste trecho seleciona-se a questão referente à contraprestação devida pelos consumidores do serviço de ensino (mensalidades, semestralidades etc.) por se tratar de tópico emblemático. Isso porque constitui aspecto nevrálgico da dimensão negocial da atividade: o pagamento do preço.

A Lei $n^{\circ}$ 9.394/1996 repete a liberdade de exploração da atividade de ensino pela iniciativa privada no artigo $7^{\circ}$, repetindo as condições impostas pelo artigo 209 da Constituição Federal de 1988 e acrescentando uma: capacidade de autofinanciamento (excetuadas as hipóteses de financiamento público, previstas no artigo 213 da Carta constitucional). Adicionalmente, o artigo 19 do mesmo diploma classifica instituições públicas e privadas de ensino: públicas são as criadas ou incorporadas, mantidas $e$ administradas pelo poder público; privadas as mantidas e administradas por pessoas físicas ou jurídicas de direito privado ${ }^{339}$.

\footnotetext{
${ }^{339}$ O artigo 20 da Lei $n^{\circ}$ 9.394/1996 discrimina entre as instituições privadas de ensino: Artigo 20. As instituições privadas de ensino se enquadrarão nas seguintes categorias: I - particulares em sentido estrito, assim entendidas as que são instituídas e mantidas por uma ou mais pessoas físicas ou jurídicas de direito privado que não apresentem as características dos incisos abaixo; II - comunitárias, assim entendidas as que são instituídas por grupos de pessoas físicas ou por uma ou mais pessoas jurídicas, inclusive cooperativas
} 
Instituições privadas, obviamente, não estão sujeitas à imposição de gratuidade do artigo 206, inciso IV, da Constituição Federal de 1988 (aplicável apenas ao ensino público em estabelecimentos oficiais). Todavia, a contratação de seus serviços, especificamente quanto a anuidades, semestralidades ou mensalidades, está regulada pela Lei $\mathrm{n}^{\circ} 9.870$, de 23 de novembro de 1999. Para os fins deste subitem, importam as disposições do artigo $5^{\circ}$ e do artigo $6^{\circ}$, caput e $\S 1^{\circ}$ :

Art. $5^{\circ}$ Os alunos já matriculados, salvo quando inadimplentes, terão direito à renovação das matrículas, observado o calendário escolar da instituição, o regimento da escola ou cláusula contratual.

Art. $6^{\circ}$ São proibidas a suspensão de provas escolares, a retenção de documentos escolares ou a aplicação de quaisquer outras penalidades pedagógicas por motivo de inadimplemento, sujeitando-se o contratante, no que couber, às sanções legais e administrativas, compatíveis com o Código de Defesa do Consumidor, e com os arts. 177 e 1.092 do Código Civil Brasileiro, caso a inadimplência perdure por mais de noventa dias.

$\S 1^{\circ} \mathrm{O}$ desligamento do aluno por inadimplência somente poderá ocorrer ao final do ano letivo ou, no ensino superior, ao final do semestre letivo quando a instituição adotar o regime didático semestral.

O interesse coletivo que circunscreve a prestação da atividade educacional faz com que esta, quando explorada pela iniciativa privada, não se submeta às regras gerais dos contratos privados. Especialmente a exceção do contrato não cumprido é relativizada nos contratos educacionais. Assim compreendeu a Ministra Eliana Calmon, do Superior Tribunal de Justiça, no Recurso Especial no $660.439^{340}$.

Conforme pontua a magistrada, a legislação interventiva diferencia o contrato de prestação de serviços educacionais em relação aos demais quanto ao momento do inadimplemento. Interpretando conjuntamente os artigos $5^{\circ}$ e $6^{\circ}$ da Lei $n^{\circ}$ 9.870/1999, a ministra compreende que o aluno somente se torna inadimplente após noventa dias da falta de pagamento. Durante o curso desse prazo, o não pagamento deve ser considerado mera impontualidade.

educacionais, sem fins lucrativos, que incluam na sua entidade mantenedora representantes da comunidade; III - confessionais, assim entendidas as que são instituídas por grupos de pessoas físicas ou por uma ou mais pessoas jurídicas que atendem a orientação confessional e ideologia específicas e ao disposto no inciso anterior; IV - filantrópicas, na forma da lei.

${ }^{340}$ BRASIL, SUPERIOR TRIBUNAL DE JUSTIÇA, Recurso Especial no 660.439, Relatora Ministra Eliana Calmon, DJ 27.06.2005. No mesmo sentido confira-se o Recurso Especial $n^{\circ}$ 725.955, Relatora Ministra Eliana Calmon (DJ 18.05.2007). 
Assim, segundo decidiu o Superior Tribunal de Justiça, pelo voto da Ministra Eliana Calmon, apenas quando o atraso supere noventa dias é que a instituição privada de ensino pode negar a renovação da matrícula. Esta, inclusive, é a única medida que a escola privada possui como resposta ao inadimplemento, no que tange a suas prestações.

Evidentemente, tem a seu dispor todas as medidas usuais de cobrança civil. Mas quanto ao serviço educacional em si, para além de negar a matrícula no período letivo seguinte, a instituição de ensino não pode impor sanções administrativas ou pedagógicas ao aluno inadimplente, nem impedir que continue frequentando as aulas e realizando as provas do período corrente, nem negar, ao final, a obtenção de documentos escolares. Não pode, por exemplo, conforme outra decisão do Superior Tribunal de Justiça, recusar-se a entregar o certificado de conclusão de curso ao aluno, em função de sua inadimplência ${ }^{341}$.

Decisões de teor semelhantes são encontradas na jurisprudência do Tribunal de Justiça do Estado de São Paulo. Exemplificativamente, cite-se trecho do voto do Desembargador Manoel de Queiroz Pereira Calças no Agravo de Instrumento $\mathrm{n}^{\mathbf{o}}$ 1.162.879-0-2: “[a] Lei no 9.870/99 (...) [garante] o direito do aluno inadimplente de prosseguir estudando durante o ano letivo, sem nenhum impedimento que possa prejudicálo em seus estudos, sendo desligado quando do término do ano letivo. O que não se pode permitir é a renovação da matrícula (...)"342.

Por fim, cumpre registrar que se o legislador intervém na autonomia das prestadoras privadas de serviço educacional, quanto à gestão de seus créditos, em nome do interesse coletivo que permeia a atividade, certo é que o mesmo fundamento legitima intervenções que as privilegiam. Assim é que, exemplificativamente, o artigo 53 da Lei ${ }^{\circ}$ 8.245 de dezoito de outubro de 1991 restringe as hipóteses de rescisão dos contratos de locação de imóveis utilizados por estabelecimentos de ensino. É, também, o embasamento do incentivo que o legislador deu aos empregadores para custearem para seus empregados educação em estabelecimentos de ensino próprios ou alheios, assegurando que os valores referentes a matrícula, mensalidade, anuidade, livros e material didático não serão

\footnotetext{
${ }^{341}$ Confira-se nesse sentido, BRASIL, SUPERIOR TRIBUNAL DE JUSTIÇA, Recurso Especial n ${ }^{\circ}$ 913.917, Relatora Ministra Mauro Campbell Marques, DJ 12.09.2008.

${ }^{342}$ Estado de São Paulo, TRibunal de Justiça do Estado de São Paulo, Agravo de Instrumento ${ }^{\circ}$ 1.162.879-0-2, Relator Desembargador Manoel de Queiroz Pereira Calças, DJ 31.03.2008. No mesmo sentido: Agravo de Instrumento 1.154.881-00/3, Relator Desembargador Amorim Cantuária (DJ 04.08.2008); Agravo de Instrumento $\mathrm{n}^{\circ}$ 1.164.984-0/7, Relator Desembargador Jayme Queiroz Lopes (DJ 02.04.2008); Agravo de Instrumento $\mathrm{n}^{\circ}$ 1.221.860-0/8, Relator Desembargador Luis de Carvalho (DJ 03.11.2008), entre outros.
} 
considerados como verba salarial (artigo 458, $\S 2^{\circ}$, inciso II, do Decreto-Lei $n^{\circ} 5.452$, de 1 de maio de 1943 - Consolidação das Leis do Trabalho). 


\section{CONCLUSÃO}

1. O conceito atribuído para a cidadania constante do inciso II do artigo $1^{\circ}$ da Constituição Federal, arrolada dentre os fundamentos da República brasileira, deve ser amplo, excedendo a tradicional identificação entre cidadania e titularidade de direitos políticos. A esse respeito, a conclusão a que se chegou nesta Dissertação pode ser sintetizada da seguinte forma: trata-se da expressão de um vínculo de pertencimento do indivíduo à sociedade estatal (à cidade), vínculo esse que impõe certas exigências. Estas, no âmbito da ciência jurídica, impõem a criação de condições concretas, normativas e materiais, para que os indivíduos que partilham desse vínculo com o Estado exerçam seus direitos fundamentais. Elas configuram-se segundo a composição do próprio direito fundamental a que se referirem. À medida que prevalecer o caráter coletivo, social ou de liberdade, ou combinarem-se os três, a solução decorrente da cidadania obedecerá a uma forma específica. Mas ela deve ter sempre o objetivo de otimizar o exercício do direito.

2. Assim, foi adotado o seguinte significado: cidadania é condição individual que indica a vinculação jurídica a determinada sociedade politicamente organizada (pertencimento), cujo efeito é permitir ao indivíduo a fruição de direitos civis, políticos e sociais. Trata-se de um pressuposto de exercício de direitos fundamentais que, muito além de sua mera titularidade no plano do direito positivo, abrange os mecanismos jurídicos de sua efetivação. Estes instrumentos correspondem à organização na Constituição e/ou na Lei da implementação desses direitos fundamentais (tal como ocorre com o direito à educação, minuciosamente regulado na Constituição Federal, desde os objetivos do sistema de ensino até as reservas orçamentárias mínimas). Ou seja, a noção de cidadania compreende tudo aquilo que permite ao indivíduo efetivamente exercer os direitos fundamentais.

3. Dada a amplitude do tema da cidadania, a seleção de um conceito específico deve ser cuidadosa e largamente informada pelos objetivos que dele são pretendidos. Em atenção à complexidade que existe em se ter a cidadania como fundamento do Estado, esta Dissertação buscou expor algumas formas que o conceito já assumiu. Para tanto, foram separadas para análise apenas aquelas que se entendeu que melhor contribuiriam para a evolução do raciocínio até a opção conceitual feita, sem ignorar que, como em toda 
escolha, sobretudo em temas de abrangência potencialmente ilimitada como é o da cidadania, a seleção de alguns objetos para o estudo negligencia muitos mais.

4. O primeiro aspecto apresentado, buscando-se investigar um momento inicial de significação, foi o da inevitável conexão entre o conceito de cidadania e o exercício ativo da democracia na antiguidade clássica, o que se fez a partir de uma breve exposição acerca da sociedade ateniense antiga. Nela, vê-se a seleção de um segmento da sociedade (homens, descendentes, proprietários etc.) ao qual gradualmente são atribuídos direitos e obrigações diretamente ligados ao exercício do poder político.

5. Constatou-se que cidadania na Grécia antiga constitui conceito voltado à atividade pública. Refere-se a uma condição, cujos atributos foram sendo incorporados à medida que se consolidava a democracia plena ateniense, em geral transmitida via laços sanguíneos, que identificava um número restrito de indivíduos como portadores de direitos e obrigações com vistas à participação ativa no processo decisório coletivo. Trata-se de uma cidadania a princípio desvinculada da idéia de critério individual de titularidade de outros direitos que não aqueles inerentes à participação na coletividade. Como mencionado na exposição do tema, residentes em Atenas não-cidadãos detinham direitos de cunho individual e, inclusive, conforme anotou ARISTÓTELES ${ }^{343}$, era-lhes viabilizado assegurá-los nos tribunais.

6. O caráter excessivamente restritivo e intimamente ligado à titularidade e ao exercício de direitos políticos que se verifica na experiência antiga é ampliado em extensão e conteúdo no processo de formação do Estado nacional. Para a exposição dessa transformação tomou-se apoio, principalmente, na obra de MARSHALL ${ }^{344}$, que conceituou cidadania através de sua decomposição em três elementos de uma qualidade atribuída ao indivíduo em determinada sociedade: um elemento civil, um elemento político e um elemento social.

7. No conceito de MARSHALL há uma tendência à universalidade e à uniformização da qualidade de cidadão a todos os membros de uma sociedade específica, com enfoque sobre o indivíduo, titular de direitos, no que difere da abordagem restritiva grega. $\mathrm{O}$ autor analisou como, na formação dos Estados nacionais, privilégios e prerrogativas feudais são transformados em direitos igualmente distribuídos a todos os membros da sociedade

\footnotetext{
343 Aristóteles , A Política... cit, p. 211.

344 Marshall, Thomas Humphrey, Ciudadania y Classe Social, in Reis, v. 79, 1997. Ou Marshall, Thomas Humphrey, Cidadania, Classe Social e Status, Rio de Janeiro, Zahar, 1967
} 
estatal, reunidos sob o conceito de cidadania. Direitos civis, políticos e sociais, em si, já existiam. Mas, na sociedade feudal, eles estavam concebidos como prerrogativas de grupos, e, embora amalgamados num só conjunto, diferiam em qualidade e intensidade conforme o status (estamento) do indivíduo ${ }^{345}$. Esse status feudal não correspondia ao status ou condição de cidadão.

8. O processo de formação nacional teve papel decisivo na evolução da cidadania. Elemento de grande relevância nesse desenvolvimento teria sido a reunião da força coercitiva em apenas um centro de poder decisório: o poder real. Esse fato foi decisivo para a definição de significados únicos de titularidade de direitos individuais e para sua defesa. Tais significados são fundamentados em leis e determinações gerais e não nos costumes de determinada localidade ou corporação. O conceito de cidadania, segundo MARSHALL, refere-se a uma condição atribuída indistintamente aos membros de uma determinada sociedade estatal, fazendo de todos os seus membros titulares iguais de direitos e deveres por ela selecionados. A universalização desse status seria interna a esse corpo social, ou seja, seria nacional.

9. Entretanto, diferenças nos diversos processos de formação dos Estados nacionais e os resultados que elas possam implicar ao pertencimento do indivíduo a determinada sociedade política são estudos que podem extrapolar a ótica jurídica, especialmente quanto à titularidade e ao exercício de direitos fundamentais. Do ponto de vista sociológico, a abordagem do tema da cidadania demanda a interpretação de incontáveis práticas sociais que compõem a história de um país.

10. Daí a conclusão de que, conforme adverte TURNER ${ }^{346}$, como entre tais práticas insere-se a jurídica, o conceito sociológico de cidadania é inexoravelmente mais amplo do que a concepção jurídica do tema. Desta constatação seguiu um alerta metodológico desta Dissertação: foi necessário identificar um significado jurídico de cidadania e, portanto, os efeitos jurídicos ensejados pelo vínculo de pertencimento inerente a essa idéia.

11. Verificou-se que em determinado momento esse pertencimento foi equivalente ao próprio rol de direitos fundamentais. E, também, que identificou o elemento que instaura no indivíduo a aptidão para a titularidade desses direitos. Mas quando o princípio da legalidade foi levado ao resguardo do Direito Internacional Público e este passou a

\footnotetext{
${ }^{345}$ MARshall, Thomas Humphrey, Ciudadania ... cit, p. 303.

346 TURner, Bryan S., Contemporary ... cit., p. 2.
} 
tutelar diretamente a pessoa humana, abandonando-se a lógica da proteção diplomática, o critério de titularidade de direitos fundamentais transbordou as fronteiras nacionais.

12. Diante disso, à cidadania nacional (ou estatal, como colocado no item 1.3 desta Dissertação) teve de ser atribuído o significado de pressuposto não de titularidade, que teria extravasado a esfera nacional, mas de exercício de direitos humanos, porque este permanece na esfera nacional. Com essa roupagem, ela passa a exigir que o Estado, representado pelo poder público, organize-se com vistas à satisfação dos direitos fundamentais de seus cidadãos. A partir desse significado abrangente, esta Dissertação analisou os dispositivos constitucionais relativos ao direito à educação e a legislação correlata, buscando identificar como são enfrentadas e como se concretizam, nesse tema, as exigências de cidadania.

13. Resumindo-se a idéia segundo a delimitação do tema desta Dissertação, cidadania foi tratada como um vínculo jurídico que reconhece o pertencimento do indivíduo à sociedade de que participa e do qual decorre a exigência de concretização de seu direito à educação. Essa exigência, do ponto de vista jurídico, materializa-se na estrutura normativa que se organiza para sua concretização, desde o texto constitucional (e, portanto, desde a própria declaração do direito na ordem interna) até a prática jurisprudencial sobre o tema.

14. Em seguida, antes da análise do conteúdo normativo propriamente dito, buscouse investigar o conteúdo da própria expressão direito à educação. Nessa seara, a primeira conclusão encontrada é que se trata de direito a um processo formativo, do qual o cidadão espera determinados resultados. Em consideração a estes, identificou-se a existência de um elemento teleológico inerente à noção de direito à educação, que no Brasil a ordem jurídica afirma ser o pleno desenvolvimento da pessoa, seu preparo para o exercício da cidadania e sua qualificação para o trabalho (artigo 205 da Constituição Federal de 1988).

15. Todavia, a despeito de sua importância, o elemento teleológico do conceito não esclarece em que consiste o mecanismo de alcance desses resultados. Esta preocupação é imprescindível à definição de educação enquanto segmento lingüístico normativo, componente da expressão direito à educação. Se é importante saber que existe um direito a que a educação permita ao indivíduo atingir determinados resultados, é da mesma forma essencial, do ponto de vista jurídico-pragmático, ter clareza acerca do formato em que isso deve ocorrer. Ou seja, deve-se responder a pergunta: a qual processo educativo se tem direito? 
16. Conceituar com clareza o direito à educação como direito fundamental exige que sejam identificados sua natureza, seus sujeitos ativos (titulares/credores) e passivos (devedores) e, principalmente, o seu objeto (o processo educativo). Esse objeto é a palavra educação da expressão direito à educação. Nesta Dissertação essa educação foi concebida como processo formativo organizado institucionalmente, ou seja, aquela que, oferecida em estabelecimentos oficiais ou não oficiais, está sujeita aos atos autorizativos do Estado bem como à sua fiscalização quanto à qualidade, e que fornece ao indivíduo a certificação validada pelo próprio sistema. É a atividade que se desenvolve na escola ${ }^{347}$, também podendo ser chamada de ensino formal ${ }^{348}$. Em que ele consiste, conforme se demonstrou, demanda a investigação do ordenamento positivo, principalmente a partir da Constituição Federal de 1988, que, nos artigos 205 e seguintes, trata com extensa pormenorização do direito à educação.

17. O esclarecimento de significados fez necessárias elucidações a respeito da estrutura do direito à educação, tema que transita livremente entre a esfera individual e a esfera pública. Demonstrou-se que ele pode ser enfocado tanto como uma premissa de satisfação pessoal, mediante o desenvolvimento das capacidades individuais que o próprio sujeito-educando espera ver desenvolvidas, como pode ser visto como um elemento integrante do bem comum de determinada sociedade, voltado ao desenvolvimento social. O direito à educação é peculiar porque possui elementos de mais de uma das dimensões de direitos fundamentais. Ao mesmo tempo é social, individual e coletivo, alternando-se, conforme a situação, os titulares e sujeitos passivos. É um direito que envolve um conjunto de obrigações jurídicas diversas, comportando obrigações de fazer e não fazer distintas segundo o sujeito passivo seja o Estado, a coletividade ou o próprio indivíduo seu titular.

18. Na dimensão não-prestacional (dimensão de liberdade) a satisfação do direito à educação se dá, por exemplo, pela abstenção estatal em impor uma religião oficial nos estabelecimentos de ensino, em definir versões da história ou em restringir a pluralidade de conteúdos. Em sua dimensão social, ele traduz uma imposição de ação ao Estado quanto à regulação da atividade educacional e quanto ao fornecimento de prestações que possibilitem a todos a concretização do direito, aparelhando-se para fornecer serviços

\footnotetext{
347 Sifuentes, Mônica, Direito Fundamental à Educação. A Aplicabilidade dos Dispositivos Constitucionais, Porto Alegre, Núria Fabris, 2009, p. 40.

${ }^{348}$ Ensino formal pode também ser tratado por educação escolar ou meramente por ensino, conforme o que estabelece o $\S 1^{\circ}$ do artigo $1^{\circ}$ da Lei $n^{\circ} 9.394 / 1996$ (Lei de Diretrizes e Bases da Educação Nacional): $\S 1^{\circ}$. Esta Lei disciplina a educação escolar, que se desenvolve, predominantemente, por meio do ensino, em instituições próprias.
} 
educacionais igualmente a todos. Já na sua dimensão coletiva, o direito à educação tutela interesses da coletividade, ou seja, de um número de sujeitos de difícil ou impossível determinação, constituindo componente inafastável da noção de bem comum enquanto finalidade do Estado.

19. A satisfação do direito à educação beneficia, evidentemente, o indivíduo, mas vai além e enriquece toda a sociedade. Interessa à democracia e aos ideais republicanos, interessa ao desenvolvimento da sociedade, e, assim, interessa ao Estado por decorrência lógica. É bem social indispensável ao desenvolvimento humano, ao crescimento econômico sustentável e à redução da pobreza. Portanto, além do Estado, o direito à educação submete o indivíduo, que é o seu titular. A contrapartida ao fato de beneficiar tanto o indivíduo como a coletividade é que o direito à educação também obriga a ambos.

20. A resposta à questão sobre qual é o objeto do direito à educação (qual o processo formativo organizado institucionalmente a que se tem direito), entretanto, somente pode ser atingida mediante a investigação do sistema jurídico positivo. Significa dizer que a formatação final do direito à educação e do modo de seu exercício, exigido pela cidadania, somente pode ser definida em relação a determinado ordenamento jurídico. $\mathrm{O}$ Estado está encarregado da tarefa de detalhar internamente o direito à educação, de modo a concretizar seu exercício, como exigência de cidadania. Tal detalhamento de exercício, certamente, condiciona o conteúdo do direito.

21. O Capítulo III desta Dissertação buscou investigar essa materialização normativa, com o objetivo de responder satisfatoriamente às perguntas feitas acerca do conteúdo do direito à educação. É no âmbito do direito positivo (e de sua aplicação) que se pode conhecer a real amplitude do exercício do direito à educação, adquirindo-se, assim, maior clareza quanto ao seu conteúdo normativo. É no plano do regramento concreto que se descobre qual é, efetivamente, o processo formativo institucional a que se tem direito.

22. Assim, a partir da Constituição Federal de 1988 procurou-se expor a estrutura do direito à educação conforme positivado pelo direito brasileiro. Para tanto, procurou-se segregar as normas constitucionais conforme prevalecesse nelas a dimensão social, a dimensão de liberdade ou a dimensão coletiva.

Todavia, essa maior clareza quanto ao conteúdo do direito à educação, exigido pela cidadania, enseja novos questionamentos, que deverão ser objeto de pesquisas futuras. 
Exemplificativamente, deverão ser objeto de novos estudos (i) a viabilidade da concretização do direito à educação de estrangeiros ilegalmente presentes no Brasil, (ii) a implementação do direito à qualidade da educação, diante da insuficiência de sua definição legislativa, (iii) pelo mesmo motivo, a legitimidade ou não do controle de qualidade feito pelo poder público sobre a educação oferecida por instituições privadas de ensino e (iv) a natureza do direito ao ensino médio antes de 2016 (se direito subjetivo público ou não, conforme suscitado no item 3.1.2.2 supra). 


\section{BIBLIOGRAFIA}

Abramovich, Víctor e Courtis, Christian, El Umbral de la Ciudadanía. El significado de los derechos sociales em el Estado social constitucional, Buenos Aires, Del Puerto, 2006.

AleXy, Robert, Teoria de los Derechos Fundamentales, Madrid, Centro de Estúdios Políticos y Constitucionalies, 2002.

Alston, Philip et BhUtA, Nehal, Human Rights and Public Goods: Education as a Fundamental Right in India, in Alston, Philip et RoBInson, Mary, Human Rights and Development: Towards Mutual Reinforcement, Oxford, Oxford University Press, 2005.

Amaral JúnIOR, Alberto do, O Direito de Assistência Humanitária, Rio de Janeiro, Renovar, 2003.

ARENDT, Hannah, As Origens do Totalitarismo: Imperialismo, a Expansão do Poder, Rio de Janeiro, Documentário, 1976, p.201.

ARISTÓteles, A Constituição de Atenas (trad. Therezinho M. Deutsch), in Aristóteles, col. Os Pensadores, São Paulo, Nova Cultural, 1999.

Aristóteles, A Política, in Aristóteles, col. Os Pensadores, São Paulo, Nova Cultural, 1999.

Barcellos, Ana Paula de, O Mínimo Existencial e Algumas Fundamentações: John Rawls, Michael Walzer e Robert Alexy, in TORRES, Ricardo Lobo (org.), Legitimação dos Direitos Humanos, Rio de Janeiro, Renovar, 2007.

Bastos, Celso Ribeiro, Curso de Direito Constitucional, São Paulo, Saraiva, 2000. 
BITTAR, Eduardo Carlos Bianca, Cidadania: condição de exercício dos direitos humanos, in Panóptica, a. 1, v.1, 2006.

BobBio, Norberto, A Era dos Direitos, Rio de Janeiro, Elsevier, 2004.

BobBIo, Norberto, Teoria Geral da Política: A Filosofia Política e as Lições dos Clássicos, Rio de Janeiro, Campus, 2000.

Bonavides, Paulo, Curso de Direito Constitucional, São Paulo, Malheiros, 2006.

Caggiano, Monica Herman S., A Educação. Direito Fundamental, in Ranieri, Nina Beatriz Stocco (coord.), Direito à Educação: Aspectos Constitucionais, São Paulo, EDUSP, 2009.

Canotilho, José Joaquim Gomes, Direito Constitucional e Teoria da Constituição, Coimbra, Almedina, 2000.

CARnelutti, Francesco, Sistema de derecho procesal civil, v. 1, Buenos Aires, UTEHA, 1944.

Carvalho, José Murilo de, Desenvolvimiento de la ciudadanía en Brasil, México, Efe, 1995.

Castro, Ana Rubio e Escudero, Mercedes Moyá, Nacionalidad y Ciudadanía: uma relación a debate, in Ciudadanía e inmigración, n. 37, 2003.

Cavalcanti, Themístocles Brandão, A Constituição Federal Comentada, v. III, Rio de Janeiro, José Konfino, 1949.

Condorcet, Marquis de (Marie Jean Antoine Nicola de Caritat), Premier Mémoire sur L'instruction Publique (1791), Paris, Mille et une nuits, 2002.

Comparato, Fabio Konder, Educação, Estado e Poder, São Paulo, Brasiliense, 1987. 
Corral, Benito Aláez, Nacionalidad y Ciudadanía ante las Exigencias del Estado Constitucional Democrático, in Estudios Políticos, n. 127, 2005.

Cortina, Adela, Ciudadanos del mundo. Hacia una teoría de la ciudadanía, Madrid, Alianza, 1999.

Cretella Júnior, José, Comentários à Constituição Brasileira de 1988, v. I, Rio de Janeiro, Forense Universitária, 1992.

CURY, Carlos Roberto Jamil, Educação escolar e educação no lar: espaços de uma polêmica, in Educação e Sociedade, v. 27, n. 96, 2009.

CURY, Carlos Roberto Jamil, Ensino religioso na escola pública: o retorno de uma polêmica recorrente, in Revista Brasileira de Educação, n. 27, 2004.

DAL Ri JÚNIOR, Arno, Evolução Histórica e Fundamentos Políticos-Jurídicos da Cidadania, in DAL Ri JúNior, Arno et OliveIRA, Odete Maria de (org.), Cidadania e Nacionalidade: efeitos e perspectivas nacionais - regionais - globais, Ijuí, Unisul, 2002.

David AraúJo, Luiz Alberto e Nunes Júnior, Vidal Serrano, Curso de Direito Constitucional, São Paulo, Saraiva, 1999.

Delmanto, Celso et al., Código Penal Comentado, Rio de Janeiro, 2002.

D’Entrevès, Alessandro Passerin, La nocion de Estado, Uma introducción a la Teoria Política, Barcelona, Ariel, 2001.

Deswarte, Marie-Pauline, Intérêt General, Bien Commun, in Revue du Droit Public et de la Science Politique en France et a L'Étranger, n. 5, Paris, 1988.

DuARTE, Clarice Seixas, A Educação como um Direito Fundamental de Natureza Social, in Educação e Sociedade, Campinas, v. 28, n. 100, 2007. 
Duarte, Clarice Seixas, Direito Público Subjetivo e Políticas Educacionais, in São Paulo em Perspectiva, v. 18(2), 2004.

Estado de São Paulo, Tribunal de Contas, Manual Básico: Aplicação de Recursos no Ensino, São Paulo, 2007, p. 12, disponível em www.tce.sp.gov.br/arquivos/manuaisbasicos/2007_aplicacao-de-recursos-no-ensino.pdf (acesso em 10.01.2010).

Fausto, Boris, O Pensamento Nacionalista Autoritário, Rio de Janeiro, Jorge Zahar, 2001.

Ferrajoli, Luigi, A Soberania no Mundo Moderno, São Paulo, Martins Fontes, 2002.

FERrAJOLI, Luigi, Derechos y garantías. La ley del más débil, Madri, Editorial Trotta, 1999.

Ferrajoli, Luigi, Más Allá de la Soberanía y la Ciudadanía: un Constitucionalismo Global, in Isonomía, n. 9, 1998.

Ferraz Junior, Tercio Sampaio, Introdução ao Estudo do Direito: Técnica, Decisão, Dominação, São Paulo, Atlas, 2001.

Ferraz Junior, Direito e Cidadania na Constituição Federal, in Revista da Procuradoria Geral do Estado de São Paulo, v. 47/48, 1997.

FERreIRA FILHO, Manoel Gonçalves, Comentários à Constituição brasileira de 1988, v. 1, São Paulo, Saraiva, 1990.

Furtado, Marcelo Gasque, Padrão de Qualidade do Ensino in RANIERI, Nina Beatriz Stocco e RighetTI, Sabine, Direito à Educação: Aspectos Constitucionais, São Paulo, EDUSP, 2009.

GARCIA, Emerson, O Direito à Educação e suas Perspectivas de Efetividade, in GARCIA, Emerson (coord.), A Efetividade dos Direito Sociais, Rio de Janeiro, Lúmen Júris, 2004. 
GLENN JR., Charles Leslie, The Myth of the Common School, Oakland, Institute for Contemporary Studies, 2002.

GLENN JR., Charles Leslie, What law can - and cannot - do in education reform, in R.CEJ, n. $31,2005$.

Greco, Rogério, Curso de Direito Penal: Parte Especial: Volume III, Niterói, Impetus, 2007.

HoROwITZ, Jonathan Thompson, The Right to Education in Occupied Territories: Making More Room for Human Rights in Occupation Law, in Yearbook of International Humanitarian Law, v. 7, 2004.

Horta, José Luiz Borges, Direito Constitucional da Educação, Belo Horizonte, Decálogo, 2007.

JeLLINEK, Georg, Sistema dei Diritti Pubblici Subbietivi, Milão, Libreria, 1912.

Jesus, Damásio E. de, Código Penal Anotado, São Paulo, Saraiva, 2001.

KENYON, Frederic George, Aristotle on the Constitution of Athens, London, 1892.

Kelsen, Hans, Teoria Pura do Direito, Coimbra, Armênio Amado, 1984.

Kymlicka, Will et Norman, Wayne, Return of the Citizen: A Survey of Recent Work on Citizenship Theory, in Ethics, v. 104, n. 2, 1994.

LAFER, Celso, A Reconstrução dos Direitos Humanos: um diálogo com o pensamento de Hannah Arendt, São Paulo, Companhia das Letras, 2006.

LuKES, Steven e GARCIA, Soledad (org.), Ciudadanía: justicia social, identidad y participación, México, Siglo Veintiuno, 1999. 
MalisKA, Marcos Augusto, Educação, Constituição e Democracia, in SouZA NeTo, Cláudio Pereira et SARMENTO, Daniel (coord.), Direitos Sociais, Fundamentos Judicialização e Direitos Sociais em Espécie, Rio de Janeiro, Lumen Júris, 2008.

ManviLle, Philip Brook, The Origins of Citizenship in Ancient Athens, Princeton University Press, 1990.

Marshall, Thomas Humphrey, Ciudadania y Classe Social, in Reis, v. 79, 1997.

Marshall, Thomas Humphrey, Cidadania, Classe Social e Status, Rio de Janeiro, Zahar, 1967.

Martines Júnior, Eduardo, Educação, Cidadania e Ministério Público - O art. 205 da Constituição e sua Abrangência, Tese (Doutorado) - Pontifícia Universidade Católica, São Paulo, 2006, p. 204.

Monteiro, Agostinho dos Reis, O Pão do Direito à Educação, in Educação e Sociedade, v. 24, n. $84,2003$.

Moraes, Alexandre de, Constituição do Brasil interpretada e legislação constitucional, São Paulo, Atlas, 2002.

Moussalem, Tárek Moysés, Conhecimento, linguagem e direito, in Jurídica - Revista do Curso de Direito da Universidade Federal do Espírito Santo, n. 2, Vitória, 2000.

Oliveira, Romualdo Portela de, Da Universalização do Ensino Fundamental ao Desafio da Qualidade, in Educação e Sociedade, v. 28, n. 100, 2007.

OliveIRA, Romualdo Portela de, Qualidade do Ensino: Uma Nova Dimensão da Luta pelo Direito à Educação, in Revista Brasileira de Educação, $\mathrm{n}^{\circ}$ 28, 2005.

PIERDONÁ, Zélia Luiza, Objetivos Constitucionais da Educação e sua Relação com os Fundamentos do Estado Brasileiro, in FerReIRA, Dâmares, Direito Educacional em Debate, São Paulo, Cobra, 2004. 
Pimenta Bueno, José Antônio, Direito Público Brasileiro e Análise da Constituição do Império, Brasília, Universidade de Brasília, 1978.

Pontes de Miranda, Francisco Cavalcanti, Comentários à Constituição de 1967: com a emenda n. 1, de 1969, Tomo IV, São Paulo, Revista dos Tribunais, 1970.

Pontes de Miranda, Francisco Cavalcanti, Direito á Educação, Rio de Janeiro, Alba, 1933.

PrÉlot, Pierre-Henri, La Séparation des Églises et de l'État, in Revue du Droit Public, t. 122, n. 3, 2006.

RANIERI, Nina Beatriz Stocco, Direito ao Desenvolvimento e Direito à Educação Relações de Realização e Tutela, in Revista dos Tribunais, a. 2, n. 6, 1994.

RANIERI, Nina Beatriz Stocco, Educação Superior, Direito e Estado na Lei de Diretrizes e Bases (Lei n. 9.394/96), São Paulo, EDUSP, 2000.

RANIERI, Nina Beatriz Stocco, O Estado Democrático de Direito e o Sentido da Exigência de Preparo da Pessoa para o Exercício da Cidadania, pela Via da Educação, Tese (LivreDocência) - Faculdade de Direito da Universidade de São Paulo, São Paulo, 2009.

RANIERI, Nina Beatriz Stocco, Os Estados e o Direito à Educação na Constituição de 1988: Comentários Acerca da Jurisprudência do Supremo Tribunal Federal, in RANIERI, Nina Beatriz Stocco e Righetti, Sabine, Direito à Educação: Aspectos Constitucionais, São Paulo, EDUSP, 2009.

RANIERI, Nina Beatriz Stocco, Estado e Nação: Novas Relações, in Revista do Instituto dos Advogados de São Paulo, n. 13, 2004.

RibeIro, Gustavo Moulin, A Cidadania Jurídica e a Concretização da Justiça, in ToRRES, Ricardo Lobo (org.), Legitimação dos Direito Humanos, Rio de Janeiro, Renovar, 2007. 
RIBEIRo, Lauro Luiz Gomes, Direito Educacional: Educação Básica e Federalismo, São Paulo, Quartier Latin, 2009.

SANCHÍs, Luis Pietro, Neoconstitucionalismo Y Ponderación Judicial, in CARBonell, Miguel (org.), Neoconstitucionalismo(os), Madrid, Trotta, 2003.

SARLET, Ingo Wolfgang, A Eficácia do Direito Fundamental à Segurança Jurídica: Dignidade da Pessoa Humana, Direitos Fundamentais e Proibição do Retrocesso Social no Direito Constitucional Brasileiro, in Arquivos de Direitos Humanos n. 6, 2006.

SARLET, Ingo Wolfgang, A Problemática dos Fundamentais Sociais como Limites Materiais ao Poder de Reforma da Constituição, in Direitos Fundamentais Sociais: Estudos de Direito Constitucional, Internacional e Comparado, Rio de Janeiro, Renovar, 2003.

SIFUEnTES, Mônica, Direito Fundamental à Educação. A Aplicabilidade dos Dispositivos Constitucionais, Porto Alegre, Núria Fabris, 2009.

Silva, José Afonso da, Comentário Contextual à Constituição, São Paulo, Malheiros, 2009.

Silva, José Afonso da, Curso de Direito Constitucional Positivo, Malheiros, São Paulo, 2008 .

Rodrigues, Silvio, Direito Civil: direito de família, São Paulo, Saraiva, 2004.

Tavares, André Ramos, Direito Fundamental à Educação, in SouZA Neto, Cláudio Pereira de, e SARMEnto, Daniel (coords.), Direitos Sociais: Fundamentos, Judicialização e Direitos Sociais em Espécie, Rio de Janeiro, Lumen Juris, 2008.

THUCYDIDES, History of the Peloponnesian War, L. II, C. I, 431 a.C. (disponível em meio eletrônico em http://classics.mit.edu/Thucydides/pelopwar.html). 
TOMASEVSKI, Katarina, Right To Education Primers: removing obstacles in the way of the right to education, Gothenburg, Novum Grafiska AB, 2001.

TORRES, Ricardo Lobo, A cidadania multidimensional na era dos direitos, in TORRES, Ricardo Lobo (org.), Teoria dos Direitos Fundamentais, Rio de Janeiro, Renovar, 1999.

TURner, Bryan S., Contemporary Problems in the Theory of Citizenship, in TURnER, Bryan S (org.), Citizenship and Social Theory, Sage, Londres, 1993.

TURnER, Bryan S., Outline of a Theory of Citizenship, in Sociology, v. 24, n. 2, 1990.

Vasconcelos, Arnaldo, A Cidadania Ateniense na Grécia Clássica, in SAlEs, Lília Maia de Morais (org.), Estudos sobre a efetivação do direito na atualidade: a Cidadania em Debate, Fortaleza, Universidade de Fortaleza, 2005.

VIEIRA, Liszt, Cidadania Global e Estado Nacional, in Dados, v. 42, n. 3, 1999.

WeIs, Carlos, Direitos Humanos Contemporâneos, São Paulo, Malheiros, 2006.

Ximenes, Salomão Barros, O Ensino Religioso nas Escolas Públicas Brasileiras: do Direito à Liberdade de Crença e Culto ao Direito à Prestação Estatal Positiva, in RANIERI, Nina Beatriz Stocco e RighetTi, Sabine, Direito à Educação: Aspectos Constitucionais, São Paulo, EDUSP, 2009. 